\title{
LAPORAN AKHIR PENELITIAN ASPEK YURIDIS TANAH TIMBUL
}

\author{
Trie Sakti \\ Ambar Nur Hadi \\ Jauhari Thontowi
}

Pusat Penelitian dan Pengembangan

Kementerian Agraria dan Tata Ruang/

Badan Pertanahan Nasional

Tahmm 2017 


\section{KATA PENGANTAR}

Seperti kita ketahui bahwa tanah sifatnya tetap tidak bertambah, sehingga nilai tanah terus mengalami peningkatan seiring dengan tingginya laju pertambahan penduduk. Adanya fenomena tanah timbul di pesisir pantai dan muara sungai seakan menjadi "hadiah" atau "anugrah" dari Tuhan kepada bangsa Indonesia.

Hadiah berupa penambahan daratan itu harus dapat dikelola untuk sebesar-besar kemakmuran rakyat. Dapat memberikan peningkatan kesejahteraan masyarakat baik untuk digunakan sebagai tempat usaha ataupun tempat menetap, dengan tetap memperhatikan ekosistem dan daya dukung lingkungan.

Kehadiran negara sangat diharapkan untuk menjawab permasalahan kemasyarakatan. Potensi tanah timbul dapat menjadi obyek pensertipikatan tanah jika penguasaannya sudah lebih dari dua puluh tahun dan terdapat kesesuaian dengan Rencana Tata Ruang Wilayah, atau jika belum ada Rencana Tata Ruang Wilayah, mendapat rekomendasi dari Pemerintah Daerah setempat.

Kami berharap hasil penelitian dapat memberi manfaat dalam penyusunan kebijakan Kementerian Agraria dan Tata Ruang/Badan Pertanahan Nasional, dan dapat menjawab permasalahan hukum, social dan ekonomi, sehingga dapat berperan aktif dan responsive dalam menjawab isu-isu kemasyarakatan.

Terima kasih diucapkan kepada responden penelitian yang sangat membantu dalam memberikan informasi terkait penelitian ini, kepada nara sumber dan rekan-rekan yang ikut memberikan sumbang saran untuk lebih sempurnanya tulisan ini.

Kami mohon maaf jika terdapat kesalahan dalam penyebutan nama, jabatan atau data yang terdapat dalam tulisan ini. 


\section{DAFTAR ISI}

\section{Kata Pengantar \\ Daftar Isi \\ Daftar Tabel \\ Daftar Gambar}

\section{BAB I. PENDAHULUAN}

1.1. Latar Belakang

1.2. Permasalahan

1.3. Tujuan

1.4. Output

1.5. Manfaat Penelitian

\section{BAB II. TINJAUAN PUSTAKA}

2.1. Pengertian Tanah Timbul

2.2. Terjadinya Tanah Timbul

2.3. Penguasaan, Penggunaan dan Pemanfaatan Tanah Timbul

2.4. Peraturan Perundang-undangan Terkait Tanah Timbul

\section{BAB III. METODOLOGI PENELITIAN}

3.1. Pendekatan Penelitian

3.2. Lokasi Penelitian

3.3. Responden Penelitian

3.4. Sumber data

3.5. Pengolahan dan Analisa Data

\section{BAB IV. GAMBARAN UMUM WILAYAH PENELITIAN}

4.1. Kabupaten Cilacap

4.2. Kabupaten Kebumen

4.3. Kabupaten Tulungagung

4.4. Kabupaten Pasuruan

4.5. Kota Pasuruan

4.6. Kabupaten Mojokerto

4.7. Kota Cirebon

4.8. Kabupaten Cirebon

4.9. Kabupaten Indramayu

4.10. Kabupaten Serang

4.11. Kabupaten Tangerang

4.12. Kota Bengkulu

4.13. Kabupaten Bengkulu Utara 


\section{BAB V. HASIL PENGUMPULAN DATA DAN PEMBAHASAN}

5.1. Lokasi Tanah Timbul

5.1.1. Kabupaten Cilacap

5.1.2. Kabupaten Kebumen

5.1.3. Kabupaten Tulungagung

5.1.4. Kabupaten Pasuruan dan Kota Pasuruan

5.1.5. Kabupaten Mojokerto

5.1.6. Kota Cirebon

5.1.7. Kabupaten Cirebon

5.1.8. Kabupaten Indramayu

5.1.9. Kabupaten Serang

5.1.10. Kabupaten Tangerang

5.1.11. Kota Bengkulu

5.1.12. Kabupaten Bengkulu Utara

5.2. Proses Terjadinya Tanah Timbul

5.3. Penguasaan dan Penggunaan Tanah di Lokasi Tanah Timbul

5.4. Pemberian Hak Atas Tanah Timbul

5.4.1. Macam Hak Atas Tanah Yang Dapat Diberikan

5.4.2. Subyek Hak Atas Tanah Timbul

5.4.3. Pendaftaran Hak Atas Tanah Timbul

5.4.4. Wilayah Pesisir

5.5. Penataan dan Pengendalian Tanah Timbul

\section{BAB VI. KESIMPULAN DAN SARAN}

6.1. Kesimpulan

6.2. Saran

\section{DAFTAR PUSTAKA}




\section{DAFTAR TABEL}

Tabel 1. Penggunaan Tanah Kabupaten Cilacap tahun 2013

Tabel 2. Gambaran Umum Penguasaan Tanah Kabupaten Cilacap

Tabel 3. Penggunaan Tanah Kabupaten Kebumen Tahun 2013

Tabel 4. Gambaran Umum Penguasaan Tanah Kabupaten Kebumen tahun 2014

Tabel 5. Pembagian Wilayah Kecamatan di Kabupaten Tulungagung

Tabel 6. Penggunaan Tanah Kabupaten Tulungagung tahun 2011

Tabel 7. Penguasaan Tanah Kabupaten Tulungagung tahun 2011

Tabel 8. Jumlah Kecamatan dan Luas Kabupaten Pasuruan

Tabel 9. Penggunaan Tanah Kabupaten Pasuruan tahun 2013

Tabel 10. Jumlah Kecamatan dan Jumlah Kelurahan di Kota Pasuruan

Tabel 11. Penggunaan Tanah Kota Pasuruan tahun 2013

Tabel 12. Penguasaan Tanah Kota Pasuruan tahun 2013

Tabel 13. Luas Wilayah Kecamatan di Kabupaten Mojokerto tahun 2016

Tabel 14. Penggunaan Tanah Kabupaten Mojokerto tahun 2016

Tabel 15. Gambaran Umum Penguasaan Tanah Kabupaten Mojokerto

Tabel 16. Luas Kecamatan dan Jumlah Penduduk Kota Cirebontahun 2015

Tabel 17. Penggunaan Tanah Kota Cirebon tahun 2015

Tabel 18. Penguasaan Tanah Kota Cirebon tahun 2015

Tabel 19. Luas Kecamatan dan Jumlah Penduduk Kabupaten Cirebon tahun 2015

Tabel 20. Penggunaan Tanah Kabupaten Cirebon tahun 2016

Tabel 21. Penguasaan Tanah Kabupaten Cirebon tahun 2016

Tabel 22. Luas Kecamatan dan Jumlah Penduduk Kabupaten Indramayu tahun 2015

Tabel 23. Penggunaan Tanah Kabupaten Indramayu tahun 2015

Tabel 24. Penguasaan Tanah Kabupaten Indramayu tahun 2015

Tabel 25. Penggunaan Tanah Kabupaten Serang tahun 2014

Tabel 26. Penguasaan Tanah Kabupaten Serang Per Kecamatan

Tabel 27. Penggunaan Tanah Kabupaten Tangerang tahun 2014

Tabel 28. Pembagian Administrasi Kota Bengkulu

Tabel 29. Penggunaan Tanah Kota Bengkulu tahun 2012

Tabel 30. Gambaran Umum Penguasaan Tanah Kota Bengkulu

Tabel 31. Luas dan Jumlah Penduduk Kabupaten Bengkulu Utara

Tabel 32. Penggunaan Tanah Kabupaten Bengkulu Utara tahun 2011

Tabel 33. Penguasaan Tanah Kabupaten Bengkulu Utara tahun 2011

Tabel 34. Penggunaan Tanah Kecamatan Kampung Laut

Table 35. Lokasi Tanah Timbul di Kabupaten Tulungagung

Tabel 36. Luasan Tanah Timbul Per Desa di Kabupaten Pasuruan

Tabel 37. Luasan Tanah Timbul Per Kelurahan di Kota Pasuruan

Tabel 38. Lokasi Tanah Timbul di Kabupaten Mojokerto

Tabel 39. Luasan Tanah Timbul Per Desa di Kota Cirebon 
Tabel 40. Luasan Tanah Timbul Per Desa di Kabupaten Cirebon Tabel 41. Luasan Tanah Timbul Per Desa di Kabupaten Indramayu Tabel 42. Luasan Tanah Timbul Per Desa di Kabupaten Serang Tabel 43. Luasan Tanah Timbul Per Desa di Kabupaten Tangerang Tabel 44. Tanah Timbul di Kota Bengkulu

Tabel 45. Matriks Hasil Penguasaan dan Penggunaan Tanah Timbul 


\section{DAFTAR GAMBAR}

Gambar 1. Peta Wilayah Kabupaten Cilacap

Gambar 2. Peta Administrasi Kabupaten Kebumen

Gambar 3. Peta Administrasi Kabupaten Tulungagung

Gambar 4. Peta Administrasi Kabupaten Pasuruan

Gambar 5. Diagram Jumlah Penduduk Kabupaten Pasuruan

Gambar 6. Peta Administrasi Kota Pasuruan

Gambar 7. Peta Administrasi Kabupaten Mojokerto

Gambar 8. Peta Wilayah Kota Cirebon

Gambar 9. Peta Administrasi Kabupaten Cirebon

Gambar 10. Peta Administrasi Kabupaten Indramayu

Gambar 11. Peta Administrasi Kabupaten Serang

Gambar 12. Peta Administrasi Kabupaten Tangerang

Gambar 13. Peta Administrasi Kota Bengkulu

Gambar 14. Kawasan Segara Anakan dan Sekitarnya

Gambar 15. Overlay Kondisi Perairan Segara Anakan tahun 1954 dan 2013

Gambar 16. Peta Penggunaan Tanah Kecamatan Kampung Laut

Gambar 17. Tanah Timbul dengan Tutupan Lahan Berupa Hutan, Tutupan Rawa dan Nipah

Gambar 18. Kantor Kecamatan Kampung Laut, Puskesmas dan Rumah Semi Permanen di Klaces

Gambar 19. Lokasi Tanah Timbul di Kabupaten Kebumen

Gambar 20. Tanah Timbul Berbatasan Dengan Kawasan Mangrove dan Foto Penggarap

Gambar 21. Lokasi Tanah Timbul dan Reklamasi di Kabupaten Kebumen di atas RTRW

Gambar 22. Lokasi tanah timbul dan pengajuan HPL oleh Pemda Tulungagung

Gambar 23. Pantai Gemah

Gambar 24. Pantai Bayem dan Sidem

Gambar 25. Tanah Timbul di Wilayah Kota Pasuruan dan Kabupaten Pasuruan

Gambar 26. Lokasi Tanah Timbul Desa Kemantren dan Gedeg

Gambar 27. Tanah Timbul di Kelurahan Pegambiran Untuk Krematorium dan Pelabuhan

Gambar 28. Tanah Timbul di Kelurahan Panjunan Untuk TPI dan Masjid

Gambar 29. Tanah Timbul di Kelurahan Kesenden Untuk Tambak dan Perumahan Jala Kesenden

Gambar 30. Lokasi Tanah Timbul di Kota Cirebon

Gambar 31. lokasi tanah timbul di Kecamatan Losari untuk tambak dan Kantor Kuwu

Gambar 32. Lokasi Tanah Timbul di Kabupaten Cirebon

Gambar 33. Lokasi tanah timbul di desa karangsong terdapat TPI, Rumah Makan dan Kantor SATPOL AIR.

Gambar 34. Lokasi Tanah Timbul di Kabupaten Indramayu

Gambar 35. Penambahan daratan di salah satu lokasi tanah timbul Desa Tenjo Ayu Kecamatan Tanara.

Gambar 36. Tanah timbul di desa Tengkura, Kecamatan Tirtayasa

Gambar 37. Penambahan daratan di salah satu lokasi tanah timbul Desa Kohod Kecamatan Pakuhaji

Gambar 38. Lokasi tanah timbul di Kota Bengkulu

Gambar 39. Deliniasi tanah timbul diatas kutipan peta tahun 1940

Gambar 40. Deliniasi tanah timbul diatas Citra tahun 2013 
Gambar 41. Tanah Timbul Kelurahan Berkas (batas jogging track)

Gambar 42. Tanah Timbul Kelurahan Sumur Meleleh

Gambar 43. Tanah Timbul Kelurahan Malabero (mess Pemda)

Gambar 44. Tanah Timbul di Pantai Jakat

Gambar 45. Tanah Timbul di Kelurahan Kandang dan Muara Dua (masuk TWA) 


\section{BAB I \\ PENDAHULUAN}

\subsection{Latar Belakang}

Tanah sebagai salah satu sumber daya alam yang penting untuk kelangsungan hidup umat manusia mempunyai potensi ekonomi yang sangat tinggi karena sifatnya yang tetap atau tidak bertambah. Oleh karenanya tanah juga berpotensi menimbulkan konflik dalam hubungan antar manusia. Sehingga terbentuknya daratan baru atau dikenal sebagai tanah timbul membawa permasalahan karena menjadi rebutan antar masyarakat dan pemerintah daerah.

Tanah timbul banyak muncul di kawasan pantai yang berdekatan dengan muara sungai besar. Tanah timbul terjadi karena karena adanya erosi tanah di hulu sungai yang kemudian hanyut terbawa arus sungai. Selanjutnya tanah-tanah hanyutan tersebut sebagian akan mengendap disepanjang aliran sungai, dan sebagian lagi terus ke muara sungai yang bersangkutan. Maka secara tidak langsung, akibat proses yang demikian berulang terjadi akan membuat endapan lumpur tersebut meluas dan meninggi, sehingga pada akhirnya membentuk sebuah daratan baru.

Tanah timbul merupakan suatu anugrah yang tak ternilai bagi mereka masyarakat yang bertempat tinggal (bermukim) di sekitar pantai ataupun sungai, khususnya bagi warga masyarakat ekonomi lemah yang mencari nafkah sebagai petani, karena sebagai sumber daya alam baru, tanah timbul merupakan daratan yang dapat dikelola dan dimanfaatkan untuk usaha pertanian, tambak, dan bahkan dapat dijadikan tempat untuk mendirikan bangunan sebagai tempat tinggal.

Berkenaan dengan munculnya tanah timbul di tepi sungai dan pantai yang dikenal dengan istilah aansibbling (Belanda), deltaber atau channelbar (Inggris), tanah oloran (Jawa Timur, tanah wedikereng (DIY), dan tanah bokongan (Surakarta), yang berpotensi menimbulkan sengketa bagi beberapa pihak, baik masyarakat yang berbatasan dengan tanah timbul tersebut, masyarakat yang melakukan aktivitas usaha di atas tanah timbul, aparat desa yang menginginkan tanah timbul sebagai sumber pendapatan desa dan pemerintah daerah kota/kabupaten, maka perlu ada kebijakan pertanahan yang dapat mengakomodir keinginan masyarakat, memberikan rasa aman dan keadilan bagi masyarakat serta dapat meningkatkan kesejahteraan masyarakat.

Berdasarkan ketentuan pasal 33 ayat 3 UUD 1945 dan pasal 2 Undang-Undang Pokok Agraria (UUPA) menyatakan bahwa : Atas dasar ketentuan pasal 33 ayat 3 Undang- Undang Dasar 1945 dan hal-hal sebagai yang dimaksud dalam pasal 1, bumi, air dan ruang angkasa termasuk kekayaan alam yang ada di dalamnya itu pada tingkatan tertinggi dikuasai oleh negara, sebagai organisasi kekuasaan seluruh rakyat. Hak menguasai dari negara termasuk dalam ayat (1) pasal ini memberi wewenang untuk: Pertama mengatur dan menyelenggarakan peruntukan, penggunaan, persediaan dan pemeliharaan bumi dan ruang angkasa tersebut. Kedua menentukan dan mengatur hubungan-hubungan hukum antara orang-orang dengan bumi, air dan ruang angkasa. Ketiga menentukan dan mengatur hubungan-hubungan hukum antara orang-orang dan perbuatan hukum yang mengenai bumi, air dan ruang angkasa. Wewenang yang bersumber pada hak menguasai dari negara tersebut pada ayat 2 pasal ini digunakan untuk mencapai sebesar-besarnya kemakmuran rakyat, dalam arti kebahagiaan, 
kesejahteraan dan kemerdekaan dalam masyarakat dan negara hukum Indonesia yang merdeka, berdaulat, adil dan makmur.

Maka berdasarkan wewenang tersebut, negara dapat menentukan bermacam-macam hak atas tanah yang dapat diberikan dan dipunyai oleh orang-orang, baik sendiri maupun bersama-sama serta badan hukum. Hak-hak atas tanah sebagaimana dimaksud merupakan hak untuk mempergunakan tanah yang bersangkutan.

Pengaturan Tanah timbul dapat ditemukan dalam ketentuan Pasal 584 juncto 589 KUHPerdata (BW) yang pada intinya menyatakan bahwa tanah timbul adalah "milik" yang menguntungkan sekalian pihak yang memiliki tanah dipertepian aliran sungai tersebut,yaitu atas dasar perlekatan (natrekking). Namun demikian, apa yang tertuang dalam pasal KUHPerdata tersebut berbeda dengan persepsi hukum adat/kebiasaan rakyat Indonesia. Dalam persepsi Hukum Adat tidak mengenal dan menggunakan asas perlekatan sebagai dasar pemilikan atas tanah. Dan sejalan dengan itu, atas dasar angka 4 Konsideran Memutuskan UUPA dengan tegas telah mencabut seluruh ketentuan yang termuat dalam Buku II KUHPerdata,yaitu sepanjang yang mengenai bumi, air dan kekayaan alam yang terkandung didalamnya.

UUPA tidak mengatur tanah timbul secara eksplisit atau tersurat, sehingga dalam menghadapi fenomena munculnya tanah timbul di pesisir pantai dan sungai yang banyak diklaim oleh masyarakat, pada tahun 1996 diterbitkan Surat Edaran Menteri Negara Agraria/KaBPN Nomor 410-1293 Tahun 1996 tentang Penertiban Status Tanah Timbul dan Tanah Reklamasi, dilakukan untuk mengatur pemberian hak atas tanah timbul.

Dalam surat edaran tersebut, pada angka ke-3, menyatakan ;

"Tanah-tanah timbul secara alami seperti delta, tanah pantai, tepi danau/situ, endapan tepi sungai, pulau timbul dan tanah timbul secara alami lainnya dinyatakan sebagai tanah yang langsung dikuasai oleh negara. Selanjutnya penguasaan/pemilikan serta penggunaannya diatur oleh Menteri Negara Agraria/Kepala Badan Pertanahan Nasional sesuai dengan peraturan perundangan yang berlaku"

Kemudian pada angka ke-4, menyatakan ;

"Sehubungan dengan hal-hal tersebut di atas maka para Kepala Kantor Wilayah Badan Pertanahan Nasional Propinsi agar segera melakukan inventarisasi tanah-tanah timbul dan tanah hilang yang terjadi secara alami. Untuk tanah yang hilang apabila sudah ada sertipikatnya agar disesuaikan. Untuk tanah yang akan direklamasi sebelumnya harus diberi tanda-tanda batasnya sehingga bisa diketahui luas tanah yang nantinya selesai direklamasi."

Selanjutnya pada tahun 2004, dalam Peraturan Pemerintah Nomor 16 tahun 2004 tentang Penatagunaan Tanah, pada pasal 12 menyebutkan bahwa Tanah yang berasal dari tanah timbul atau hasil reklamasi di wilayah perairan pantai, pasang surut, rawa, danau, dan bekas sungai dikuasai langsung oleh Negara. Tanah timbul menurut penjelasan PP Nomor 16 tahun 2004 adalah daratan yang terbentuk secara alami maupun buatan karena proses pengendapan di sungai, danau, pantai dan atau pulau timbul, serta penguasaan tanahnya dikuasai negara.

Kemudian pada tahun 2016, diterbitkan Peraturan Menteri Agraria dan Tata Ruang/KBPN Nomor 17 tahun 2016 tentang Penataan Pertanahan Di Wilayah Pesisir Dan Pulau-pulau Kecil, pada pasal 1 angka 8 disebutkan bahwa tanah timbul adalah daratan yang terbentuk secara alami karena proses pengendapan di sungai, danau dan pantai dan atau 
pulau timbul serta penguasaan tanahnya dikuasai oleh Negara. Dalam peraturan ini disebutkan bahwa tanah timbul merupakan tanah yang dikuasai langsung oleh Negara meliputi tanah timbul pada pesisir laut, tepian sungai, tepian danau dan pulau. Selanjutnya disebutkan bahwa tanah timbul yang luasnya lebih dari 100 meter persegi dapat diberikan hak atas tanah dengan ketentuan penguasaan dan pemilikan hak atas tanah timbul harus mendapat rekomendasi dari Kementerian Agraria dan Tata ruang/BPN, penggunaan dan pemanfaatannya sesuai dengan arahan peruntukannya dalam rencana tata ruang wilayah provinsi/kabupaten/kota atau rencana zonasi wilayah pesisir dan pulau-pulau kecil.

Pengaturan tanah timbul juga terkait dengan UU Nomor 26 tahun 2007 tentang Tata Ruang, UU Nomor 23 tahun 2014 tentang Pemerintah Daerah dan UU Nomor 27 tahun 2007 yang direvisi dengan UU Nomor 1 tahun 2014 tentang Pengelolaan Wilayah Pesisir dan PulauPulau Kecil. Dalam pasal 6 UU Nomor 27 tahun 2007 disebutkan bahwa Pengelolaan Wilayah Pesisir dan Pulau-Pulau Kecil wajib dilakukan dengan cara mengintegrasikan kegiatan:

1) antara Pemerintah dan Pemerintah Daerah;

2) antar-Pemerintah Daerah;

3) antarsektor;

4) antara Pemerintah, dunia usaha, dan Masyarakat;

5) antara Ekosistem darat dan Ekosistem laut; dan

6) antara ilmu pengetahuan dan prinsip-prinsip manajemen.

Secara umum undang-undang ini mencakup pemberian hak kepada masyarakat untuk mengusulkan penyusunan Rencana Strategis, Rencana Zonasi, Rencana Pengelolaan, serta Rencana Aksi Pengelolaan Wilayah Pesisir dan Pulau-Pulau Kecil; pengaturan mengenai Izin Lokasi dan Izin Pengelolaan kepada Setiap Orang dan Masyarakat Hukum Adat, Masyarakat Lokal, dan Masyarakat Tradisional yang melakukan pemanfaatan sumber daya wilayah pesisir dan pulau-pulau kecil; pengaturan pemanfaatan pulau-pulau kecil dan perairan di sekitarnya; serta pemberian kewenangan kepada Menteri, gubernur, dan bupati/wali kota dalam Pengelolaan Wilayah Pesisir dan Pulau-Pulau Kecil.

Walaupun sudah diatur dalam beberapa peraturan perundangan, permasalahan mengenai tanah timbul masih terus berlangsung, klaim dari masyarakat bahwa tanah timbul merupakan tanah "tak bertuan" sehingga mereka dapat dengan bebas menggunakan tanah timbul, kemudian ada klaim dari Perhutani bahwa tanah timbul merupakan kawasan hutan, selain itu aparat desa juga ingin menggunakan tanah timbul sebagai asset desa, demikian juga dengan pemerintah daerah mengklaim tanah timbul sebagai asset Pemda.

Berkenan dengan banyaknya permasalahan terkait tanah timbul, terutama klaim pemilikan atas tanah timbul, maka penelitian ini ingin mendapatkan gambaran proses terjadinya tanah timbul, kepada siapa tanah timbul diberikan, penguasaan, penggunaan dan pemanfaatannya, termasuk kemungkinan untuk memberikan tanah timbul sebagai bagian dari obyek reforma agraria. 


\subsection{Permasalahan}

Berdasarkan latar belakang tersebut maka permasalahan penelitian adalah :

1. Bagaimana penguasaan, peruntukan, penggunaan dan pemanfaatan hak atas tanah timbul?

2. Apakah terhadap tanah timbul di kawasan pantai atau sungai dimungkinkan diberikan suatu hak atas tanah?

3. Bagaimana penataan dan pengendalian terhadap tanah timbul ?

\subsection{Tujuan}

1. Mengetahui penguasaan, peruntukan, penggunaan dan pemanfaatan hak atas tanah timbul .

2. Mengetahui kemungkinan pemberian suatu hak atas tanah terhadap tanah timbul di kawasan pantai atau sungai .

3. Mengetahui bentuk penataan dan pengendalian terhadap tanah timbul.

\subsection{Output}

Tersedianya laporan akhir penelitian yang memuat :

1. Penguasaan, peruntukan, penggunaan pemanfaatan hak atas tanah timbul.

2. Pelaksanaan kebijakan terkait pemberian hak atas tanah timbul.

3. Penataan dan pengendalian terhadap pemanfaatan hak atas tanah timbul .

\subsection{Manfaat Penelitian}

Hasil penelitian ini diharapkan akan bermanfaat dalam penyusunan kebijakan hukum nasional yang berkaitan dengan pemberian hak atas tanah timbul, serta penguasaan, peruntukan, penggunaan dan pemanfaatan hak atas tanah serta pengendaliannya. 


\section{BAB II \\ TINJAUAN PUSTAKA}

\subsection{Pengertian Tanah Timbul}

Kawasan daerah pesisir pantai selalu mengalami perubahan bentuk dan luas lahan yang berakibat pula pada panjang garis pantai. Perubahan itu terjadi akibat perubahan iklim, pengaruh alam pasang surut air laut, dan adanya sedimentasi pada bagian muara sungai. Perubahan-perubahan itu biasa dikenal dengan istilah-istilah akresi, abrasi, dan sedimentasi. Sehingga dibeberapa tempat muncul tanah timbul akibat dari adanya sedimentasi, dan dibeberapa tempat ada lahan yang tenggelam rusak karena pengaruh abrasi/ akresi.

beberapa tempat tertentu, seperti di tepi pantai, sungai, dan danau, karena peristiwa alam, membuat bidang tanah pada lokasi tersebut menjadi bertambah luasnya. Pertambahan luas tanah tersebut disebabkan karena adanya erosi tanah di hulu sungai yang kemudian hanyut terbawa arus sungai.

Ada beberapa penulis yang memberikan definisi mengenai tanah timbul, antara lain adalah:

a. Menurut Soedarsono dan Tominaga, terjadinya Tanah Timbul dikarenakan sungai mengalirkan air bersama-sama sedimen yang terdapat aliran air tersebut. Di bagian hulu kandungan sedimennya tinggi, tetapi sesampainya dibagian hilir terjadilah pengendapan membentuk endapan deluvial atau aluvial. Dengan terjadinya proses sedimentasi, maka terbentuklah daratan aluvial yang luas dan rata dan berkembang menjadi tempat berbagai kegiatan masyarakat . ${ }^{1}$

b. Menurut G.Kartasapoetro, tanah timbul atau aanslibbing adalah tanah yang terjadi akibat erosi berton-ton tanah yang dihanyutkan oleh air hujan yang menuju ke sungaisungai besar dimana tanah hanyutan tersebut sebagian akan mengendap disepanjang sungai dan sebagian terus ke muara sungai yang bersangkutan. Akibat berkali-kali terjadi erosi maka terjadilah aanslibbing atau tanah timbul. ${ }^{2}$

c. Menurut Boedi Harsono, definisi tanah timbul adalah tanah pantai/laut/sungai yang selalu mendapatkan penambahan tanah/tanah timbul baru. yang disebabkan oleh aliran sungai yang membawa endapan tanah hasil pengikisan kemudian mengalami pengedapan yang lama kelamaan membentuk tanah di tepi pantai. Pengendapan ini secara alami memakan waktu yang lama. Pertumbuhan ini membentuk tanah baru di tepi laut yang disebut lidah tanah atau aanslibbing. ${ }^{3}$

d. Roestandi dalam Rofi Wahanisa dan Arif Hidayat menjelaskan bahwa tanah timbul disebut dengan istilah tanah oloran yaitu tanah yang timbul di tepi sungai akibat endapan lumpur yang terbawa oleh alur sungai.

\footnotetext{
http//peralihan hak atas tanah.html

2 G. Kartasapoetra, Hukum tanah jaminan UUPA bagi keberhasilan pendapatan tanah; Bina Aksara, Jakarta, 1998, Hal. 49.

3 Riza Indria, 2003, Upaya penyelesaian sengketa tanah antara Desa mojo dan Desa Pesantren, Skripsi Undip, Semarang, hal 18.
} 
e. Selanjutnya Urip Santoso dalam bukunya menyebutkan dengan istilah lidah tanah yaitu tanah yang timbul atau muncul di tepi arus sungai yang berbelok. Tanah ini berasal dari endapan lumpur yang makin meninggi dan mengeras. Timbulnya tanah ini bukan karena kesengajaan dari seseorang atau pemilik tanah yang berbatasan, melainkan terjadi secara alamiah. Sementara itu, dari hasil penelitian yang telah dilakukan masyarakat setempat lebih mengenal tanah timbul dengan istilah tanah datang.

\subsection{Terjadinya Tanah Timbul}

Terjadinya tanah timbul dapat disebabkan oleh factor alam atau hasil tindakan manusia.

A. Faktor alam yang dapat menyebabkan terjadinya tanah timbul antara lain :4

1) Muatan sungai terlalu besar

Karena meluapnya air sungai (banjir) tenaga air mampu mengangkat seluruh muatan maka tidak terjadi pengendapan bahkan mungkin terjadi pengikisan yang lamakelamaan menimbulkan aliran sungai yang berganti arah (berbelok) dan menimbulkan tanah tumbuh.

2) Terhentinya aliran sungai

Terhentinya aliran sungai maka tenaga pengangkut tidak ada, karena berat jenis muatan lebih berat dari pada berat jenis air, terjadilah pengendapan dan lama kelamaan muncul tanah timbul.

3) Aliran sungai terhadang

Adanya material mengendap pada aliran sungai dapat mengganggu aliran sungai dan dapat menyebabkan terjadinya pengendapan sehingga lama kelamaan muncul tanah timbul.

4) Sungai yang makin melebar

Jika sungai semakin melebar, maka aliran sungai menjadi tersebar yang mengakibatkan tenaga pengangkut yang berasal dari aliran sungai berkurang dan terjadilah pengendapan yang lama kelamaan muncul tanah timbul. Pada awalnya tanah timbul bisa terjadi karena proses alam, tetapi tindakan manusia bisa mempercepat terjadinya atau penambahan bentuk, jumlah dan luas tanah timbul.

\section{B. Perbuatan Manusia}

Tanah yang timbul akibat dari perbuatan manusia, baik disengaja maupun tidak disengaja misalnya :

1) Ekosistem mangrove di pesisir pantai sudah mengalami perubahan dimana sesuai fungsinya sebagai hutan lindung, namun kenyataannya di lapangan ekosistem

4 Riza Indria, Upaya penyelesaian sengketa tanah antara Desa mojo dan Desa Pesantren, Skripsi Undip, Semarang 2003 
mangrove sudah menjadi tambak yang diusahakan oleh masyarakat dengan komoditi berupa ikan bandeng dan udang. ${ }^{5}$

2) Pemasangan patok-patok batas di pantai yang terlihat semakin dangkal, sebagai tanda klaim atas lahan pantai yang akan timbul menjadi daratan baru. Pada saat lahan tersebut telah timbul menjadi daratan, secara adat atau kesepakatan lokal telah sah sebagai lahan miliknya. Kemudian pemiliknya tinggal membuat tanggul mengelilingi lahan tersebut, mengeruk bagian tengahnya sehingga terbentuk petak tambak baru. Pemiliknya dapat pula memanfaatkannya untuk penggunaan lain seperti lahan pertanian atau rumah tinggal/pemukiman.

3) Reklamasi, merupakan usaha memperluas tanah pertanian dengan memanfaatkan daerah-daerah yang semula tidak berguna, contoh daerah rawa. Penggunaan lahan dengan cara reklamasi ini adalah dengan menimbun daerah sawah tersebut

\subsection{Penguasaan, Pemilikan, Penggunaan dan Pemanfaatan Tanah Timbul}

Pembukaan lahan baru merupakan salah satu cara lahirnya penguasaan atas sebidang tanah, yaitu apabila tanah kosong yang tidak ada pemiliknya, misalnya hutan desa, digarap, maka tanah tersebut nantinya akan menjadi miliknya. Ketentuan pembukaan lahan kosong berupa hutan desa sebagaimana dimaksud menurut warga sama halnya dengan pembukaan tanah timbul. Perbedaannya hanya terlihat pada tata cara pembukaannya saja, yaitu apabila tanah tersebut berbentuk hutan, maka orang yang ingin mengusakannya harus terlebih dahulu menebang pepohonan dan membersihkannya dari akar belukar, sehingga tanah tersebut dapat digunakan untuk keperluannya.

Menurut UUPA, setiap tanah yang keberadaannya akibat faktor alam maka secara otomatis dikuasai oleh negara. Jadi, pada intinya tanah/ lahan timbul akibat dari pengaruh sedimentasi yang terjadi di wilayah pesisir pantai adalah berstatus tanah negara. Namun dalam kenyataannya, lahan-lahan timbul langsung diklaim sebagian masyarakat sebagai lahan kepemilikan dengan cara membuat tambak-tambak. Hal itu muncul apakah dari ketidaktahuan atau pura-pura tidak tahu dari masyarakat tentang aturan kepemilikan suatu lahan atau kurangnya peraturan yang ada pada tingkat daerah yang mengatur soal tanah timbul.

Namun pada kasus lainnya, ada beberapa tanah timbul yang tidak langsung dikapling-kapling masyarakat tetapi dibiarkan tanpa ada yang mengelolanya. Tanah-tanah ini kemudian ditumbuhi oleh vegetasi pioner penyusun hutan mangrove. Dalam Perkembangan terakhir, sudah mulai ada tuntutan dari masyarakat pesisir bahwa hutan mangrove yang ada sekarang, baik yang keberadaannya secara alami maupun hasil dari kegiatan rehabilitasi mangrove oleh pemerintah, masyarakat, LSM dan CSR, diusulkan untuk ditetapkan sebagai kawasan lindung pantai atau juga sebagai kawasan konservasi.

Menurut Maria Sumardjono, pengertian "penguasaan" dapat dipakai dalam makna fisik dan yuridis, yaitu privat maupun publik. Selanjutnya dijelaskan bahwa penguasaan secara yuridis merupakan penguasaan yang dilandasi hak yang dilindungi oleh hukum dan pada

5 Kuncoro Ariawan, Setiasih Irawanti, 2005, Kajian Tambak Di Hutan Mangrove Pantai Utara Jawa Kasus Kabupaten Subang) The Study Fishpond On Mangrove Area At The North Coast Of Java (The Case Of Subang District). 
umumnya memberikan kewenangan kepada pemegang hak untuk menguasai secara fisik yang menjadi haknya, misalnya pemilik tanah mempergunakan dan mengambil manfaat dari tanah yang menjadi haknya, tidak diserahkan kepada pihak lain. Adanya penguasaan secara yuridis walaupun memberi kewenangan untuk menguasai yang hak secara fisik, namun kenyataannya penguasaan fisik dilakukan oleh orang lain. Misalnya saja, seseorang yang memiliki tanah tidak mempergunakannya sendiri melainkan tanah tersebut disewakan kepada orang lain. Tetapi ada juga yang penguasaan secara yuridis tidak memberikan kewenangan untuk menguasai tanah yang bersangkutan secara fisik, misalnya saja kreditor atau bank sebagai pemegang hak jaminan atas tanah mempunyai hak penguasaan secara yuridis atas tanah yang telah dijadikan jaminan oleh pemiliknya. Akan tetapi secara fisik penguasaanya tetap pada pemegang hak atas tanah. ${ }^{6}$

UUPA memberi pengertian bahwa dikuasai bukanlah berarti dimiliki, akan tetapi adalah pengertian memberi kewenangan kepada negara, sebagai organisasi kekuasaan dari bangsa Indonesia itu, untuk tingkatan tertinggi:

a. Mengatur dan menyelenggarakan peruntukan, penggunaan, persediaan dan pemeliharaannya;

b. Menentukan dan mengatur hak-hak yang dapat dipunyai atas (bagian dari) bumi, air, dan ruang angkasa itu;

c. Menentukan dan mengatur hubungan-hubungan hukum antara orang-orang dan perbuatan-perbuatan hukum yang mengenai bumi,air dan ruang angkasa. Dengan demikian, berdasarkan Pasal 33 ayat (3) UUD 1945 juncto Pasal 4 ayat (1) dan (2) UUPA, dapat disimpulkan bahwa Bumi, air, dan kekayaan alam yang terkandung di dalamnya di kuasai oleh negara dan dipergunakan untuk sebesar-besar kemakmuran rakyat,atas dasar hak menguasai dari negara sebagaimana dimaksud maka ditentukan adanya macam-macam hak atas permukaan bumi, yang disebut tanah (dalam hal ini termasuk tanah timbul), hak-hak tanah yang dimaksud adalah memberi wewenang untuk mempergunakan tanah yang bersangkutan.

Wewenang pada hak menguasai dari negara sebagaimana tersebut diatas digunakan untuk mencapai sebesar-besar kemakmuran rakyat dalam arti kebangsaan, kesejahteraan, dan kemerdekaan dalam masyarakat dan negara hukum Indonesia yang merdeka, berdaulat, adil dan makmur. Maka berdasarkan wewenang tersebut, negara dapat menentukan bermacammacam hak atas tanah yang dapat diberikan dan dipunyai oleh orang-orang, baik sendiri maupun bersama-sama serta badan hukum. Hak-hak atas tanah sebagaimana dimaksud merupakan hak untuk mempergunakan tanah yang bersangkutan. ${ }^{7}$

Adapun macam-macam hak-hak atas tanah tersebut dapat dilihat dalam Pasal 16 ayat (1) UUPA, yaitu sebagai berikut:

a. Hak milik

b. Hak guna usaha

6 Maria SW Sumardjono. 2008. Tanah dalam Perspektif Hak Ekonomi, Sosial dan Budaya. Jakarta, PT Kompas Media Nusantara

7 Pasal 4 ayat (1) dan (2) Undang-Undang Nomor 5 Tahun 1960 tentang Peraturan Dasar Pokok-Pokok Agraria. 

c. Hak guna bangunan
d. Hak pakai
e. Hak sewa,
f. Hak membuka tanah,
g. Hak memungut hasil hutan,
h. Hak-hak lain yang tidak termasuk dalam hak-hak tersebut diatas yang akan
ditetapkan dengan undang-undang, serta hak-hak yang sifatnya sementara sebagai yang disebutkan dalam Pasal 53.

Tanah negara yang dapat dimohon menjadi tanah hak dapat berupa :

1. Tanah negara yang masih kosong atau murni, tanah negara yang dikuasai langsung dan belum dibebani hak suatu apapun.

2. Tanah yang habis jangka waktunya, karena hak guna bangunan, hak guna usaha, hak pakai mempunyai masa berlaku yang terbatas, dengan lewatnya jangka waktu berlakunya maka hak atas tanah tersebut menjadi hapus dan tanahnya menjadi tanah negara. Bekas pemegang hak dapat memohon perpanjangan jangka waktu itu atau memohon hak yang baru diatas tanah itu.

3. Tanah negara yang berasal dari pelepasan hak oleh pemiliknya secara sukarela, pemegang hak atas tanah dapat melepaskan haknya dan dengan dilepaskannya hak itu maka tanah yang bersangkutan menjadi tanah negara. ${ }^{8}$

Tanah timbul umumnya sudah dikuasai masyarakat secara fisik baik untuk pertanian, tambak dan perumahan, untuk perolehan haknya secara yuridis dimungkinkan dalam PP Nomor 24 tahun 1997, pasal 24 ayat 2 bahwa dalam hal tidak atau tidak lagi tersedia secara lengkap alatalat pembuktian sebagaimana dimaksud pada ayat (1), pembukuan hak dapat dilakukan berdasarkan kenyataan penguasaan fisik bidang tanah yang bersangkutan selama 20 (dua puluh) tahun atau lebih secara berturut-turut oleh pemohon pendaftaran dan pendahulu pendahulunya, dengan syarat :

a. penguasaan tersebut dilakukan dengan itikad baik dan secara terbuka oleh yang bersangkutan sebagai yang berhak atas tanah, serta diperkuat oleh kesaksian orang yang dapat dipercaya.

b. penguasaan tersebut baik sebelum maupun selama pengumuman sebagaimana dimaksud dalam Pasal 26 tidak dipermasalahkan oleh masyarakat hukum adat atau desa/kelurahan yang bersangkutan ataupun pihak lainnya.

Berkaitan dengan pemberian hak atas tanah timbul, pasal 15 Peraturan Menteri Agraria dan Tata Ruang/Badan Pertanahan Nasional Nomor 17 tahun 2016 menyatakan bahwa :

(1) tanah timbul adalah tanah yang dikuasai langsung oleh negara

(2) tanah timbul meliputi tanah yang timbul pada pesisir laut, tepian sungai, tepian danau dan pulau.

(3) Tanah timbul dengan luasan paling luas $100 \mathrm{~m} 2$ (seratus meter persegi) merupakan milik dari pemilik tanah yang berbatasan langsung dengan tanah timbul dimaksud.

8 Maria. S.W. Sumardjono, Kebijakan Pertanahan : Antara Regulasi dan Implementasi, Kompas, cetakan ke IV, Jakarta, 2007, 
(4) Terhadap tanah timbul yang luasnya lebih dari $100 \mathrm{~m} 2$ (seratus meter persegi) dapat diberikan hak atas tanah dengan ketentuan :

a. Penguasaan dan pemilikan tanah timbul harus mendapat rekomendasi dari Kementerian Agraria dan Tata Ruang/Badan Pertanahan Nasional;

b. Penggunaan dan pemanfaatannya sesuai dengan arahan peruntukannya dalam rencana tata ruang wilayah provinsi/kabupaten/kota, atau rencana zonasi wilayah pesisir dan pulau-pulau kecil.

Selanjutnya dalam pasal 16 disebutkan bahwa pemberian hak atas tanah pada tanah hasil reklamasi dan tanah timbul dapat dilakukan sesuai dengan ketentuan peraturan perundangundangan yang berlaku.

\subsection{Peraturan Perundang-undangan terkait Tanah Timbul}

1. Undang-Undang

A. UU no. 32/1990 tentang Pengelolaan Kawasan Lindung

Pasal 1 ayat (6) menyatakan :

"Sempadan Pantai adalah kawasan tertentu sepanjang pantai yang mempunyai manfaat penting untuk melestarikan fungsi pantai"

Pasal 13

"Perlindungan terhadap sempadan pantai dilakukan untuk melindungi wilayah pantai dari kegiatan yang menganggu keseltarian fungsi pantai."

Pasal 14

"Kriteria sempadan pantai adalah daratan sepanjang tepian yang lebarnya propesional dengan bentuk dan kondisi fisik pantai minimal 100 meter dari titik pasang tertinggi ke arah darat".

B. UU Nomor 26 tahun 2007 tentang Penataan Ruang

Pasal 7 Ayat (1) menyatakan :"Negara menyelenggarakan penataan ruang untuk sebesar besar kemakmuran rakyat".

Ayat (2) menyatakan "Dalam melaksanakan tugas sebagaimana dimaksud pada ayat (1), negara memberikan kewenangan penyelenggaraan penataan ruang kepada pemerintah dan pemerintah daerah"

Ayat (3) menyatakan "Penyelenggaraan penataan ruang sebagaimana dimaksud pada ayat (2) dilakukan dengan tetap menghormati hak yang dimiliki orang sesuai dengan ketentuan peraturan perundang -undangan".

Hal ini berarti bahwa penyelenggaraan penataan ruang kewenangannya diserahkan kepada daerah masing - masing dengan tetap menghormati hak yang dimiliki orang atau masyarakat setempat yang bertujuan untuk untuk sebesar - besarnya kesejahteraan masyarakat.

C. Undang-Undang Nomor 27 Tahun 2007 tentang Pengelolaan Wilayah Pesisir dan PulauPulau Kecil jo Undang-Undang Nomor 1 Tahun 2014 Tentang Perubahan Atas Undangundang Nomor 27 Tahun 2007 tentang Wilayah Pesisir dan Pulau-Pulau Kecil.

Pemilikan dan penguasaan tanah di wilayah pesisir dimungkinkan dalam Undang-Undang Nomor 27 Tahun 2007 tentang Pengelolaan Wilayah Pesisir dan Pulau-Pulau Kecil yang pada 
perkembangannya kemudian diganti dengan Undang-Undang Nomor 1 Tahun 2014 Tentang Perubahan Atas Undang-undang Nomor 27 Tahun 2007 tentang Wilayah Pesisir dan PulauPulau Kecil.

Ruang lingkup pengaturan Wilayah Pesisir dalam Undang-Undang Pesisir, yakni ruang lautan yang masih dipengaruhi oleh kegiatan di daratan dan ruang daratan yang masih terasa pengaruh lautnya, serta Pulau-Pulau Kecil dan perairan sekitarnya yang merupakan satu kesatuan dan mempunyai potensi cukup besar yang pemanfaatannya berbasis sumber daya, lingkungan, dan masyarakat.

Keberadaan Undang-Undang Nomor 27 Tahun 2007 tentang Pengelolaan Wilayah Pesisir dan Pulau-Pulau Kecil sangat strategis untuk mewujudkan keberlanjutan pengelolaan sumber daya wilayah pesisir dan pulau-pulau kecil serta meningkatkan kesejahteraan Masyarakat yang bermukim di wilayah pesisir dan pulau-pulau kecil.

Pengelolaan Wilayah Pesisir dan Pulau-Pulau Kecil juga dilakukan dengan tetap mengakui dan menghormati kesatuan-kesatuan Masyarakat Hukum Adat serta hak-hak tradisionalnya sesuai dengan prinsip Negara Kesatuan Republik Indonesia, serta mengakui dan menghormati Masyarakat Lokal dan Masyarakat Tradisional yang bermukim di wilayah pesisir dan pulaupulau kecil.

Pasal 1 angka 1

Pengelolaan Wilayah Pesisir dan Pulau-Pulau Kecil adalah suatu pengoordinasian perencanaan, pemanfaatan, pengawasan, dan pengendalian sumber daya pesisir dan pulaupulau kecil yang dilakukan oleh Pemerintah dan Pemerintah Daerah, antarsektor, antara ekosistem darat dan laut, serta antara ilmu pengetahuan dan manajemen untuk meningkatkan kesejahteraan rakyat.

Pasal 1 angka 2

Wilayah Pesisir adalah daerah peralihan antara Ekosistem darat dan laut yang dipengaruhi oleh perubahan di darat dan laut.

Pasal 1 angka 3

Pulau Kecil adalah pulau dengan luas lebih kecil atau sama dengan 2.000 km2 (dua ribu kilo meter persegi) beserta kesatuan Ekosistemnya.

Pasal 1 angka 7

Perairan Pesisir adalah laut yang berbatasan dengan daratan meliputi perairan sejauh 12 (dua belas) mil laut diukur dari garis pantai, perairan yang menghubungkan pantai dan pulau-pulau, estuari, teluk, perairan dangkal, rawa payau, dan laguna.

Pasal 1 angka 8

Kawasan adalah bagian Wilayah Pesisir dan Pulau-Pulau Kecil yang memiliki fungsi tertentu yang ditetapkan berdasarkan kriteria karakteristik fisik, biologi, sosial, dan ekonomi untuk dipertahankan keberadaannya.

Pasal 1 angka 21 menyatakan ; 
"Sempadan Pantai adalah daratan sepanjang tepian yang lebarnya proporsional dengan bentuk dan kondisi fisik pantai, minimal 100 (seratus) meter dari titik pasang tertinggi ke arah darat".

Pasal 31 Ayat (1) menyatakan;

"Pemerintah Daerah menetapkan batas sempadan pantai yang disesuaikan dengan karakteristik topografi, biofisik, hidrooseonografi pesisir, kebutuhan ekonomi dan budaya, serta ketentuan lain"

D. Undang-Undang Nomor 23 Tahun 2014 tentang Pemerintahan Daerah

Sedangkan ke arah daratan ditetapkan sesuai dengan batas kecamatan untuk kewenang-an Kewenangan kabupaten/kota ke arah laut ditetapkan sejauh sepertiga dari wilayah laut kewenangan provinsi sebagai-mana telah ditetapkan dalam Undang-Undang Nomor 32 Tahun 2004 jo. Undang-Undang Nomor 23 Tahun 2014 tentang Pemerintahan Daerah, sedangkan ke arah daratan ditetapkan sesuai dengan batas kecamatan.

Pasal 27

(1) Daerah provinsi diberi kewenangan untuk mengelola sumber daya alam di laut yang ada di wilayahnya.

(2) Kewenangan Daerah provinsi untuk mengelola sumber daya alam di laut sebagaimana dimaksud pada ayat (1) meliputi:

a. eksplorasi, eksploitasi, konservasi, dan pengelolaan kekayaan laut di luar minyak dan gas bumi;

b. pengaturan administratif;

c. pengaturan tata ruang;

d. ikut serta dalam memelihara keamanan di laut; dan

e. ikut serta dalam mempertahankan kedaulatan negara.

(3) Kewenangan Daerah provinsi untuk mengelola sumber daya alam di laut sebagaimana dimaksud pada ayat (1) paling jauh 12 (dua belas) mil laut diukur dari garis pantai ke arah laut lepas dan/atau ke arah perairan kepulauan.

(4) Apabila wilayah laut antardua Daerah provinsi kurang dari 24 (dua puluh empat) mil, kewenangan untuk mengelola sumber daya alam di laut dibagi sama jarak atau diukur sesuai dengan prinsip garis tengah dari wilayah antardua Daerah provinsi tersebut.

(5) Ketentuan sebagaimana dimaksud pada ayat (3) dan ayat (4) tidak berlaku terhadap penangkapan ikan oleh nelayan kecil.

\section{Peraturan Pemerintah}

A. Peraturan Pemerintah Republik Indonesia No. 16 tahun 2004 Tentang Penatagunaan Tanah.

Penetapan Rencana tata Ruang Wilayah tidak mempengaruhi hubungan hukum atas tanah yang telah ada haknya baik yang belum maupun yang telah terdaftar, hal ini dapat dijelaskan pada Peraturan Pemerintah Republik Indonesia No. 16 Tahun 2004 tentang Penatagunaan Tanah, bunyinya sebagai berikut : 
Pasal 6

Kebijakan penatagunaan tanah diselenggarakan terhadap:

a. bidang-bidang tanah yang sudah ada haknya baik yang sudah atau belum terdaftar;

b. tanah negara;

c. tanah ulayat masyarakat hukum adat sesuai dengan ketentuan peraturan perundangundangan yang berlaku.

Pasal 9

(1) Penetapan Rencana Tata Ruang Wilayah tidak mempengaruhi status hubungan hukum atas tanah.

(2) Penetapan Rencana Tata Ruang Wilayah tidak mempengaruhi status hubungan hukum atas tanah sebagaimana dimaksud dalam Pasal 6 yang di atas atau di bawah tanahnya dilakukan pemanfaatan ruang.

Pasal 15

"Penggunaan dan pemanfaatan tanah pada pulau-pulau kecil dan bidang-bidang tanah yang berada disempadan pantai, sempadan danau, sempadan waduk, dan atau sempadan sungai, harus memperhatikan :

a. kepentingan umum;

b. keterbatasan daya dukung, pembangunan yang berkelanjutan, keterkaitan ekosistem, pembangunan yang berkelanjutan, keanekaragaman hayati serta kelestarian lingkungan.

B. Peraturan Pemerintah Nomor 38 Tahun 2011 tentang Sungai .

Pasal 1

bahwa Sungai adalah "alur atau wadah air alami dan/atau buatan berupa jaringan pengaliran air beserta air di dalamnya, mulai dari hulu sampai muara, dengan dibatasi oleh garis sempadan yang merupakan garis maya di kiri dan kanan palung sungai yang di tetapkan sebagai batas pelindung sungai.

Pasal 8 ayat (2)

bahwa garis sempadan sungai di tentukan pada sungai :

a.Tidak bertanggul di dalam kawasan perkotaan;

b. Tidak bertanggul di luar kawasan perkotaan;

c.Bertanggul di dalam kawasan perkotaan;

d.Bertanggul di luar kawasan perkotaan.

Pasal 9 Khusus sungai tidak bertanggul di kawasan perkotaan, penentuan garis sempadannya adalah:

1. Paling sedikit 10 meter dari tepi kiri dan kanan palung sungai, sepanjang alur sungai, dalam hal kedalaman sungai kurang dari atau sama dengan 3 meter.

2. Paling sedikit 15 meter dari tepi kiri dan kanan palung sungai, sepanjang alur sungai, dalam hal kedalaman sungai lebih dari 3 meter sampai dengan 20 meter.

3. Paling sedikit 30 meter dari tepi kiri dan kanan palung sungai, sepanjang alur sungai, dalam hal kedalaman sungai lebih dari 20 meter. 
Pasal 10 Untuk kawasan di luar perkotaan yang tidak bertanggul, penentuan garis sempadan di bedakan menjadi 2 bagian yaitu sebagai berikut :

1. Untuk sungai besar, dengan luas DAS lebih besar dari $500 \mathrm{~km}$ (lima ratus kilo meter persegi) ditentukan paling sedikit berjarak 100 meter dari tepi kiri dan dan kanan.

2. Untuk sungai kecil, dengan luas DAS lebih besar dari $500 \mathrm{~km}$ (lima ratus kilo meter persegi) ditentukan paling sedikit berjarak 50 meter dari tepi kiri dan kanan.

\section{Peraturan Menteri}

Peraturan Menteri Negara Agraria/KBPN Nomor. 17 tahun 2016 tentang Penataan Pertanahan di Wilayah Pesisir dan Pulau-Pulau Kecil.

Pasal 1 angka 2

Perairan Pesisir adalah laut yang berbatasan dengan daratan meliputi perairan sejauh 12 (dua belas) mil laut diukur dari garis pantai, perairan yang menghubungkan pantai dan pulau-pulau, estuari, teluk, perairan dangkal, rawa, payau dan laguna.

Pasal 1 angka 6

Pantai adalah daerah yang merupakan pertemuan antara laut dan daratan diukur pada saat pasang tertinggi dan surut terendah.

Pasal 1 angka 7

Sempadan pantai adalah daratan sepanjang tepian lebarnya proporsional dengan bentuk dan kondisi fisik pantai minimal 100 (seratus) meter dari titik pasang tertinggi ke arah darat.

\section{Surat Edaran Menteri Negara Agraria/KaBPN Nomor 410-1293 Tahun 1996 tentang Penertiban Status Tanah Timbul dan Tanah Reklamasi}

Angka 1 :

Tanah-tanah yang hilang secara alami, baik karena abrasi pantai, tenggelam atau hilang karena longsor, tertimbun atau gempa bumi, atau pindah ke tempat lain karena pergeseran tempat (land slide) maka tanah-tanah tersebut dinyatakan hilang dan haknya hapus dengan sendirinya. Selanjutnya pemegang haknya tidak dapat minta ganti rugi kepada siapapun dan tidak berhak menuntut apabila di kemudian hari di atas bekas tanah tersebut dilakukan reklamasi/penimbunan dan/atau pengeringan (polder). 


\section{BAB III \\ METODE PENELITIAN}

\subsection{Pendekatan Penelitian}

Penelitian ini merupakan penelitian Yuridis Empiris, untuk melihat penerapan hukum (terkait tanah timbul) di tengah masyarakat.

Hasil penelitian yang telah diperoleh, baik dari penelitian lapangan maupun dari penelitian kepustakaan kemudian disusun dalam sebuah laporan yang bersifat deskriptif analisis yaitu pendekatan studi kasus dan penelitian lapangan (Case Studies and Field Research) untuk memperoleh gambaran secara rinci dan sistematis terhadap permasalahan penelitian, berdasarkan gambaran dan fakta yang diperoleh kemudian dianalisis untuk menjawab permasalahan penelitian. Analisis dilakukan baik dari aspek yuridis maupun analisa data spasial.

\subsection{Lokasi Penelitian}

Pemilihan lokasi secara purposive yakni wilayah yang diindikasikan terdapat tanah timbul dengan luasan relatif besar :
a) Jawa Barat
b) Jawa Tengah
c) Jawa Timur
d) Banten
e) Bengkulu

\subsection{Responden Penelitian}
a) Kantor Wilayah : Kepala Kantor dan Kepala Bidang
b) Kantor Pertanahan : Kepala Kantor dan Kepala Seksi
c) Pemerintah Daerah :Bappeda/Dinas Tata Ruang
d) Kepala Desa/Tokoh Masyarakat
e) Masyarakat yang menguasai tanah timbul

\subsection{Sumber Data}

A. Data Primer :

1) Pengamatan langsung di lapangan

2) Hasil wawancara dan kuesioner dari: Instansi terkait, Pihak Swasta dan Masyarakat yang menguasai tanah timbul.

B. Data Sekunder (sebagai pendukung) :
1) Peta Administrasi Wilayah
2) Peta Rencana Pola Ruang
3) Neraca Penatagunaan Tanah Kabupaten/Kota
4) Citra Satelit Google Earth 


\section{5) Peta IP4T}

\subsection{Pengolahan dan Analisa Data}

a) Hasil kuesioner diolah dan dianalisis berdasarkan peraturan perundang-undangan dan berdasarkan implikasi langsung terhadap masyarakat yang berada disekitar kawasan tanah timbul.

b) Hasil interview digunakan untuk mempertajam analisa.

c) Data sekunder (peta) ditampilkan untuk menggambarkan kondisi spasial yaitu perbedaan antara sebelum dan sesudah adanya tanah timbul, penambahan luas daratan dan juga untuk keperluan analisa kesesuaian penggunaan tanah dengan rencana tata ruang wilayah. 


\section{BAB IV \\ GAMBARAN UMUM WILAYAH PENELITIAN}

\subsection{Kabupaten Cilacap}

Kabupaten Cilacap merupakan daerah terluas di Jawa Tengah, dengan batas wilayah sebelah selatan Samudra Indonesia, sebelah utara berbatasan dengan Kabupaten Banyumas, Kabupaten Brebes dan Kabupaten Kuningan Propinsi Jawa Barat, sebelah timur berbatasan dengan Kabupaten Kebumen dan sebelah barat berbatasan dengan Kabupaten Ciamis dan Kota Banjar Propinsi Jawa Barat.

Kabupaten Cilacap merupakan salah satu kabupaten di Provinsi Jawa Tengah yang terletak disebelah selatan dan berada di pesisir selatan Pulau Jawa. Dahulu juga terdapat Kota Administrastif Cilacap yang terdiri dari 3 (tiga) Kecamatan yaitu Kecamatan Cilacap Utara, Kecamatan Cilacap Tengah dan Kecamatan Cilacap Selatan. Namun sejak diberlakukannya Undang-undang Nomor 22 tahun 1999 tentang Pemerintahan Daerah status Kota Administratif ditiadakan dan Kotif Cilacap kembali menjadi bagian dari wilayah Kabupaten Cilacap. Hari lahir Kabupaten Cilacap ditetapkan pada tanggal 21 Maret $1856 .^{9}$

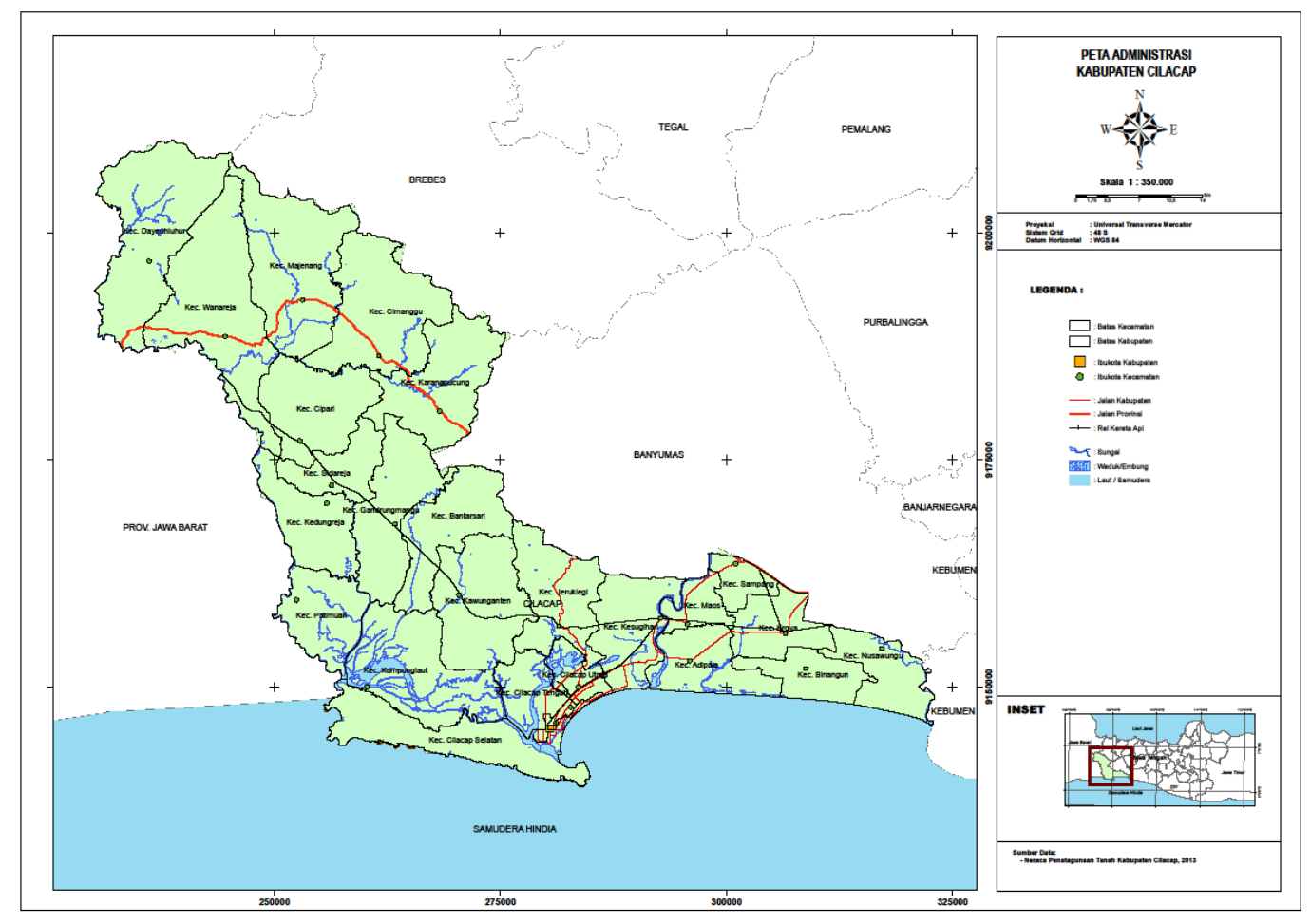

Sumber : Neraca Penatagunaan Tanah Kab. Cilacap 2013, Kanwil BPN Prov. Jawa Tengah (diolah).

Gambar 1. Peta Wilayah Kabupaten Cilacap

\footnotetext{
${ }^{9}$ https://id.wikipedia.org/wiki/Kabupaten_Cilacap
} 
Secara kultural Kabupaten Cilacap merupakan daerah pertemuan budaya Jawa (Banyumasan) dengan budaya Sunda (Priangan Timur). Sebagian penduduk Kabupaten Cilacap ada yang bertutur dalam bahasa Sunda, terutama di kecamatan-kecamatan yang berbatasan dengan Jawa Barat, dikarenakan bahwa pada masa lalu wilayah kabupaten ini adalah bagian dari Kerajaan Galuh. ${ }^{10}$

Di Kabupaten Cilacap juga terdapat area khusus di Pulau Nusakambangan, yang merupakan pulau yang tertutup, yaitu terdapat Lembaga Pemasyarakatan (LP) Kelas I yang sampai saat ini masih aktif. Di sekitar Pulau Nusakambangan juga terdapat areal unik yang telah menarik perhatian para peneliti untuk melakukan riset karena tingkat sedimentasinya yang sangat tinggi yaitu kawasan Segara Anakan. Kawasan ini juga telah ditetapkan dalam Kawasan Strategis Nasional oleh pemerintah.

\subsubsection{Kondisi Fisik Wilayah}

Wilayah Kabupaten Cilacap secara geografis berada pada posisi antara $108^{\circ} 04^{\prime} 30^{\prime \prime}-$ $109^{\circ} 30^{\prime} 30^{\prime \prime}$ BT dan $7^{\circ} 30^{\prime} 00^{\prime \prime}-7^{\circ} 45^{\prime} 20^{\prime \prime}$ LS. Dengan luas wilayah 237.172,68 ha / $2.371,7268 \mathrm{~km}^{2}$ Kabupaten Cilacap merupakan kabupaten dengan wilayah terluas di Provinsi Jawa Tengah atau sekitar 6,8\% dari total luasnya.

Secara administrasi Kabupaten Cilacap terbagi menjadi 24 Kecamatan yang terdiri dari 269 Desa dan 15 Kelurahan dengan batas-batas wilayah administrasinya sebagai berikut :

a. Sebelah Utara berbatasan dengan Kabupaten Brebes;

b. Sebelah Timur berbatasan dengan Kabupaten Banyumas dan Kabupaten Kebumen;

c. Sebelah Selatan berbatasan dengan Samudera Hindia;

d. Sebelah Barat berbatasan dengan wilayah Provinsi Jawa Barat yaitu Kabupaten Ciamis, Kota Banjar dan Kabupaten Kuningan.

Secara Topografi Kabupaten Cilacap mempunyai kondisi wilayah relatif datar di bagian selatan dan berbukit pada bagian utara. Bagian selatan umumnya mempunyai ketinggian antara $0-25$ meter dari permukaan laut, sedangkan di bagian utara dengan ketinggian berkisar antara $25-1.200$ meter dari permukaan laut. Wilayah yang termasuk bagian selatan adalah Kecamatan Gandrungmangu, Bantarsari, Kedungrejo, Kawunganten Jeruklegi, Patimuan, Kampunglaut, Cilacap Selatan, Cilacap Tengah, Cilacap Utara, Kesugihan, Maos, Adipala, Sampang, Kroya, Binangun dan Kecamatan Nusawungu. Sedangkan bagian utara meliputi Kecamatan Sidareja, Cipari, Karangpucung, Cimanggu, Majenang, Wanareja dan Dayeuhluhur. Kecamatan Dayeuhluhur merupakan wilayah tertinggi dengan ketinggian antara $198-1.210$ meter dari permukaan laut dan terdapat Gunung Pojoktiga yang menjadi titik tertinggi di Kabupaten Cilacap dengan ketinggian 1.347 meter diatas permukaan laut.

Kondisi hidrologi Kabupaten Cilacap secara umum bisa dibagi menjadi tiga mainstream yaitu Sungai Citanduy, Sungai Serayu - Kali ljo dan Segara Anakan . Sungai Citanduy yang merupakan batas wilayah antara Provinsi Jawa Tengah dengan wilayah Provinsi Jawa Barat. Sebagian besar anak sungai yang bermuara ke Sungai Citanduy hulunya berada di wilayah Provinsi Jawa Barat, sedangkan anak sungai yang berada dalam wilayah Provinsi Jawa Tengah adalah Sungai Cijolang dan Sungai Cikawung. Kedua anak sungai tersebut luasnya lebih kurang 83.800 ha. Sungai Serayu dan Kali ljo muaranya masuk dalam wilayah Kabupaten

\footnotetext{
${ }^{10} \mathrm{https} / / /$ id.wikipedia.org/wiki/Kabupaten_Cilacap.
} 
Cilacap dengan hulu dari kedua sungai tersebut masuk dalam wilayah Kabupaten Banyumas dan Kabupaten Banjarnegara. Luas kedua sungai tersebut adalah kebih kurang 58.374 ha. Sedangkan Sungai Segara Anakan mempunyai anak-anak sungai antara lain Sungai Cibereum, Sungai Cimeneng dan Sungai Jeruklegi dengan luas lebih kurang 102.183 ha.

\subsubsection{Kondisi Sosial Ekonomi Wilayah}

Jumlah penduduk tahun 2011 di Kabupaten Cilacap adalah sebanyak 1.755.268 jiwa, yang terdiri dari penduduk laki-laki sebanyak 879.198 jiwa $(50,09 \%)$ dan penduduk perempuan sebanyak 876.070 jiwa (49,91\%), dengan jumlah Kepala Keluarga sebanyak 452.344 KK, dan sex ratio sebesar 100,36 \%, yang berarti setiap 1000 jiwa penduduk perempuan terdapat 1.004 jiwa penduduk laki-laki. Pertambahan penduduk sebesar 32.662 jiwa dari Tahun 2006 sebanyak 1.722.607 jiwa sampai Tahun 2011 menjadi sebesar 1.755.268 jiwa, dengan pertumbuhan ratarata sebesar $0,32 \%$ tiap tahunnya.

Tingkat kepadatan penduduk di Kabupaten Cilacap rata-rata adalah 740 jiwa/Km2. Kecamatan dengan tingkat kepadatan tertinggi berada di Kecamatan Cilacap Utara yaitu sebesar 2.307 jiwa/Km2. Sedangkan kecamatan dengan tingkat kepadatan terendah berada di Kecamatan Kampunglaut yaitu sebesar 116 jiwa/Km2. Kecamatan dengan jumlah penduduk terbanyak adalah Kecamatan Majenang yaitu sebanyak 126.175 jiwa, dan kecamatan dengan jumlah penduduk terendah berada di Kecamatan Kampunglaut yaitu sebanyak 16.840 jiwa.

Dalam hal perekonomian, pertanian merupakan sektor utama perekonomian masyarakat di Kabupaten Cilacap. Komoditi pertanian di Kabupaten Cilacap adalah komoditas tanaman pangan yang meliputi : padi, jagung, kedelai, kacang tanah, kacang hijau, ubi kayu, dan ubi jalar. Sementara subsektor nelayan digeluti oleh sebagian besar penduduk yang tinggal di pesisir pantai selatan.

Akan tetapi Cilacap lebih dikenal dengan industrinya. Cilacap adalah satu dari tiga kawasan industri utama di Jawa Tengah (selain Semarang dan Surakarta). Sektor ini juga merupakan sektor yang memberikan distribusi terbesar bagi perekonomian di Kabupaten Cilacap, dengan kontribusi pada PDRB kabupaten sebesar Rp. 61.887,99,- milyar atau sebesar $60,39 \%$. Disusul perdagangan, hotel dan restoran pada urutan kedua dengansebesar 27,09\%. Sektor pertanian menjadi urutan ke tiga terhadap PDRB yaitu sebesar 6,04\%. Sektor jasa keuangan, persewaan, jasa perusahaan / financial, listrik, air minum, bangunan dan pertambangan mendapat urutan ke empat dengan 4,70\% dan terakhir sektor angkutan dan komunikasi menjadi penyumbang PDRB terkecil yaitu sebesar 1,78 \%.

Di Cilacap terdapat 6 (enam) industri besar antara lain yaitu : Pertamina Refinery Unit IV, Pabrik Semen Holcim Indonesia, Pabrik Gula Rafinasi (PT. DHARMAPALA USAHA SUKSES), Pabrik Tepung Panganmas Inti Persada, PLTU Karangkandri, Pengolahan Ikan PT. Juifa Internasional. Disamping industri yang sudah ada, di Kota Cilacap masih tersedia kawasan untuk pengembangan sektor industri.

Selain dari sektor-sektor diatas, sektor Pekerja Imigran (TKI/TKW)" juga menyumbangkan banyak devisa terutama karena kiriman uang (remitan) mereka ke daerah asal, remitan dan devisa tersebut merupakan potensi ekonomi yang cukup besar. Buruh imigran tersebut berasal dari seluruh kecamatan yang ada di wilayah Kabupaten Cilacap, untuk saat ini kecenderungan buruh imigran tersebut tidak lagi ke Malaysia, Singapura atau Brunei Darussalam tetapi ke negara-negara Asia Timur, yang menjadi tempat tujuan antara lain Korea 
Selatan, Hongkong dan Taiwan, kecuali tempat tujuan Asia Timur saat ini semakin banyak juga imigran (TKI/TKW) dengan tujuan ke negara Timur Tengah.

\subsubsection{Penggunaan Tanah}

Berdasarkan data penggunaan tanah Kabupaten Cilacap tahun 2013 terlihat bahwa penggunaan tanah yang paling dominan di wilayah Kabupaten Cilacap adalah berupa tanah pertanian (meliputi sawah irigasi, tegalan, kebun campuran, perkebunan dan tambak), yaitu sebesar $56,48 \%$ dari luas wilayah Kabupaten Cilacap.

Jenis penggunaan tanah di Kabupaten Cilacap berdasarkan penyebaran pada setiap kecamatan dapat diuraikan sebagai berikut :

a. Penggunaan tanah sawah di Kabupaten Cilacap seluas $80.014,32 \mathrm{Ha}(33,74 \%$ dari luas wilayah Kabupaten Cilacap), terdiri dari sawah $1 x$ padi seluas $6.324,81 \mathrm{Ha}(2,67 \%)$ dan sawah $2 x$ padi seluas $73.689,51 \mathrm{Ha}(31,07 \%)$. Penggunaan tanah sawah $2 x$ padi terdapat di seluruh kecamatan wilayah Kabupaten Cilacap, yang terluas terdapat di Kecamatan Patimuan seluas 5.607,71 Ha, sedangkan luasan terendah terdapat di Kecamatan Cilacap selatan seluas $318,21 \mathrm{Ha}$.

b. Penggunaan tanah tegalan di Kabupaten Cilacap seluas $14.690,10 \mathrm{Ha}(6,19 \%)$ terdapat pada setiap wilayah kecamatan, kecuali di Kecamatan Kroya.

c. Penggunaan tanah kebun campuran di Kabupaten Cilacap seluas 28.817,89 Ha $(12,15 \%)$, terdapat pada setiap wilayah kecamatan kecuali di Kecamatan Kampunglaut.

d. Penggunaan tanah berupa perkebunan di Kabupaten Cilacap seluas 10.218,61 Ha $(4,31 \%)$.

e. Penggunaan tanah berupa hutan di Kabupaten Cilacap seluas $8.730,84 \mathrm{Ha}(3,68 \%)$, penggunaan tanah hutan terluas berada di Kecamatan Cilacap Selatan seluas $6.795,11 \mathrm{Ha}$ dan luasan terendah berada di Kecamatan Cimanggu seluas 1,35 Ha;

f. Penggunaan tanah hutan rawa di Kabupaten Cilacap seluas 6.682,37 Ha $(2,82 \%)$, terluas berada di Kecamatan Kampunglaut seluas 4.525,33 Ha.

g. Penggunaan tanah hutan sejenis di Kabupaten Cilacap seluas 31.986,56 Ha $(13,49 \%)$, penggunaan tanah hutan sejenis terluas berada di Kecamatan Dayeuhluhur seluas 6.048,67 Ha, sedangkan luasan terendah berada di Kecamatan Cipari seluas 407,78 Ha;

h. Penggunaan tanah belukar di Kabupaten Cilacap seluas 6.407,60 Ha (2,70\%), berada di Kecamatan Adipala, Bantarsari, Cilacap Selatan, Cilacap Tengah, Cimanggu, Cipari, Dayeuhluhur, Gandrungmangu, Karangpucung, Kawunganten, Kedungreja, Kesugihan, Majenang, dan Wanareja. Penggunaan tanah belukar terluas berada di Kecamatan Cilacap Selatan seluas 3.546,82 Ha, sedangkan luasan terendah berada di Kecamatan Kesugihan seluas 0,01 Ha; 
Tabel 1. Penggunaan Tanah Kabupaten Cilacap Tahun 2013 (Baru)

\begin{tabular}{|c|l|r|r|}
\hline No & Penggunaan Tanah & Luas (ha) & \% Wilayah \\
\hline 1 & Belukar & $6,407.60$ & 2.70 \\
\hline 2 & Hutan & $8,730.84$ & 3.68 \\
\hline 3 & Hutan Rawa & $6,682.37$ & 2.82 \\
\hline 4 & Hutan Sejenis & $31,986.56$ & 13.49 \\
\hline 5 & Industri & 171.43 & 0.07 \\
\hline 6 & Instalasi & 371.35 & 0.16 \\
\hline 7 & Kampung & $37,184.91$ & 15.68 \\
\hline 8 & Kebun Campuran & $28,817.89$ & 12.15 \\
\hline 9 & Kuburan & 109.62 & 0.05 \\
\hline 10 & Lapangan & 109.99 & 0.05 \\
\hline 11 & Pasir & 112.32 & 0.05 \\
\hline 12 & Perkebunan & $10,218.61$ & 4.31 \\
\hline 13 & Rawa & $4,402.20$ & 1.86 \\
\hline 14 & Rumput & 996.87 & 0.42 \\
\hline 15 & Sawah 1 X padi & $6,324.81$ & 2.67 \\
\hline 16 & Sawah 2 X padi & $73,689.51$ & 31.07 \\
\hline 17 & Sungai & $5,864.55$ & 2.47 \\
\hline 18 & Tadus/Batu & 63.97 & 0.03 \\
\hline 19 & Tambak & 213.58 & 0.09 \\
\hline 20 & Tegalan & $14,690.10$ & 6.19 \\
\hline 21 & Waduk/Embung & 23.61 & 0.01 \\
\hline Grand Total & $\mathbf{2 3 7 , 1 7 2 . 6 8}$ & $\mathbf{1 0 0 . 0 0}$ \\
\hline
\end{tabular}

Sumber : Neraca Penatagunaan Tanah Kabupaten Cilacap Tahun 2013, Kanwil BPN Prov. Jawa Tengah.

\subsubsection{Penguasaan tanah}

Penguasaan tanah yang ada di Kabupaten Cilacap meliputi Hak Milik sebesar 66,98 persen dari luas wilayah, kemudian penguasaan tanah oleh Kehutanan sebesar 19.89 persen, penguasaan tanah oleh Menkumham untuk Nusakambangan sebesar 5,98 persen, dan yang paling kecil adalah penguasaan tanah untuk waduk sebesar 0,01 persen.

Tabel 2. Gambaran Umum Penguasaan Tanah Kabupaten Cilacap Tahun 2013

\begin{tabular}{|c|l|r|r|}
\hline No & Penguasaan tanah & Luas (ha) & \% Wilayah \\
\hline 1 & Dikelola Kehutanan & $47,184.57$ & 19.89 \\
\hline 2 & HGB & 896.83 & 0.38 \\
\hline 3 & HGU & $10,061.82$ & 4.24 \\
\hline 4 & HM & $158,859.31$ & 66.98 \\
\hline 5 & HP & 102.66 & 0.04 \\
\hline 6 & Dikelola Menkumham & $14,179.32$ & 5.98 \\
\hline 7 & Sungai & $5,864.55$ & 2.47 \\
\hline 8 & Waduk/Embung & 23.61 & 0.01 \\
\hline \multicolumn{2}{|l|}{ Grand Total } & $\mathbf{2 3 7 , 1 7 2 . 6 8}$ & $\mathbf{1 0 0 . 0 0}$ \\
\hline
\end{tabular}

Sumber : Neraca Penatagunaan Tanah Kabupaten Cilacap 2013, Kanwil BPN Prov. Jawa Tengah.

Sebaran penguasaan tanah yang terdapat di Kabupaten Cilacap meliputi : 
a. Tanah Hak Milik seluas $158.859,31 \mathrm{Ha}(66,98 \%)$, terdapat di setiap kecamatan yang ada di wilayah Kabupaten Cilacap;

b. Tanah Hak Guna Bangunan (HGB) seluas $896,83 \mathrm{Ha}(0,38 \%)$, terdapat di wilayah Kecamatan Adipala, Cilacap Selatan, Cilacap Tengah, Cilacap Utara, Kesugihan, dan Kecamatan Maos;

c. Tanah Hak Guna Usaha (HGU) seluas $10.061,82 \mathrm{Ha}(4,42 \%)$, terdapat di wilayah Kecamatan Cimanggu, Cipari, Dayeuhluhur, Jeruklegi, Karangpucung, Kawunganten, Majenang, dan Kecamatan Wanareja;

d. Tanah Hak Pakai (HP) seluas 102,66 Ha (0,04\%), terdapat di beberapa wilayah kecamatan, yaitu : di Kecamatan Cilacap Selatan, Cilacap Tengah, Cilacap Utara, Jeruklegi, dan Kecamatan Kesugihan;

e. Tanah dikelola oleh Menkumham seluas $14.179,32 \mathrm{Ha}$ (5,98\%), terletak di wilayah Kecamatan Cilacap Selatan (wilayah Nusakambangan), dan Kecamatan Kampunglaut;

f. Tanah dikelola oleh Kehutanan seluas $47.184,57 \mathrm{Ha}(19,89 \%)$, berada hampir di setiap kecamatan di wilayah Kabupaten Cilacap, kecuali Kecamatan Binangun, Kroya, Maos, Nusawungu, dan Kecamatan Sampang;

\subsection{Kabupaten Kebumen}

Wilayah Kabupaten Kebumen terletak disebelah selatan dan berada di pesisir selatan Pulau Jawa. Nama Kebumen konon berasal dari kabumian yang berarti sebagai tempat tinggal Kyai Bumi setelah dijadikan daerah pelarian Pangeran Bumidirja atau Pangeran Mangkubumi dari Mataram pada 26 Juni 1677, saat berkuasanya Sunan Amangkurat I (Al Faqir, 2017). Sebelumnya, daerah ini sempat tercatat dalam peta sejarah nasional sebagai salah satu tonggak patriotik dalam penyerbuan prajurit Mataram di zaman Sultan Agung ke benteng pertahanan Belanda di Batavia. Saat itu Kebumen masih bernama Panjer.

\subsubsection{Kondisi Fisik Wilayah}

Kabupaten Kebumen merupakan salah satu kabupaten di Provinsi Jawa Tengah yang secara geografis wilayahnya berada pada posisi antara $7^{\circ} 37^{\prime}-7^{\circ} 50^{\prime}$ LS dan $109^{\circ} 22^{\prime}-109^{\circ} 87^{\prime}$ BT. Kabupaten Kebumen secara administratif terdiri dari 26 kecamatan, luas wilayah Kabupaten Kebumen berdasarkan Neraca Penatagunaan Tanah Kanwil BPN Provinsi jawa Tengah tahun 2013 adalah 133.243,55 Ha. Kecamatan dengan wilayah terluas berada di Kecamatan Karanggayam yaitu $11.457,98 \mathrm{Ha}$ (8,60\% dari luas wilayah Kabupaten Kebumen), sedangkan kecamatan dengan luas terkecil berada di Kecamatan Gombong yaitu $1.961,30 \mathrm{Ha}(1,47 \%)$.

Topografi Kabupaten Kebumen terdiri atas daerah pantai (pesisir), dataran rendah, perbukitan dan sebagian merupakan lereng pegunungan. Strata pantai (pesisir) terletak di sebelah selatan. Strata dataran rendah membentang sepanjang jalan raya (jalan propinsi) mulai dari ujung timur yang berbatasan dengan Kabupaten Purworejo sampai dengan ujung barat yang berbatasan dengan Kabupaten Banyumas dan Cilacap. Sedangkan Strata perbukitan (pegunungan) di bagian utara, berbatasan dengan Kabupaten Banjarnegara dan Wonosobo. 


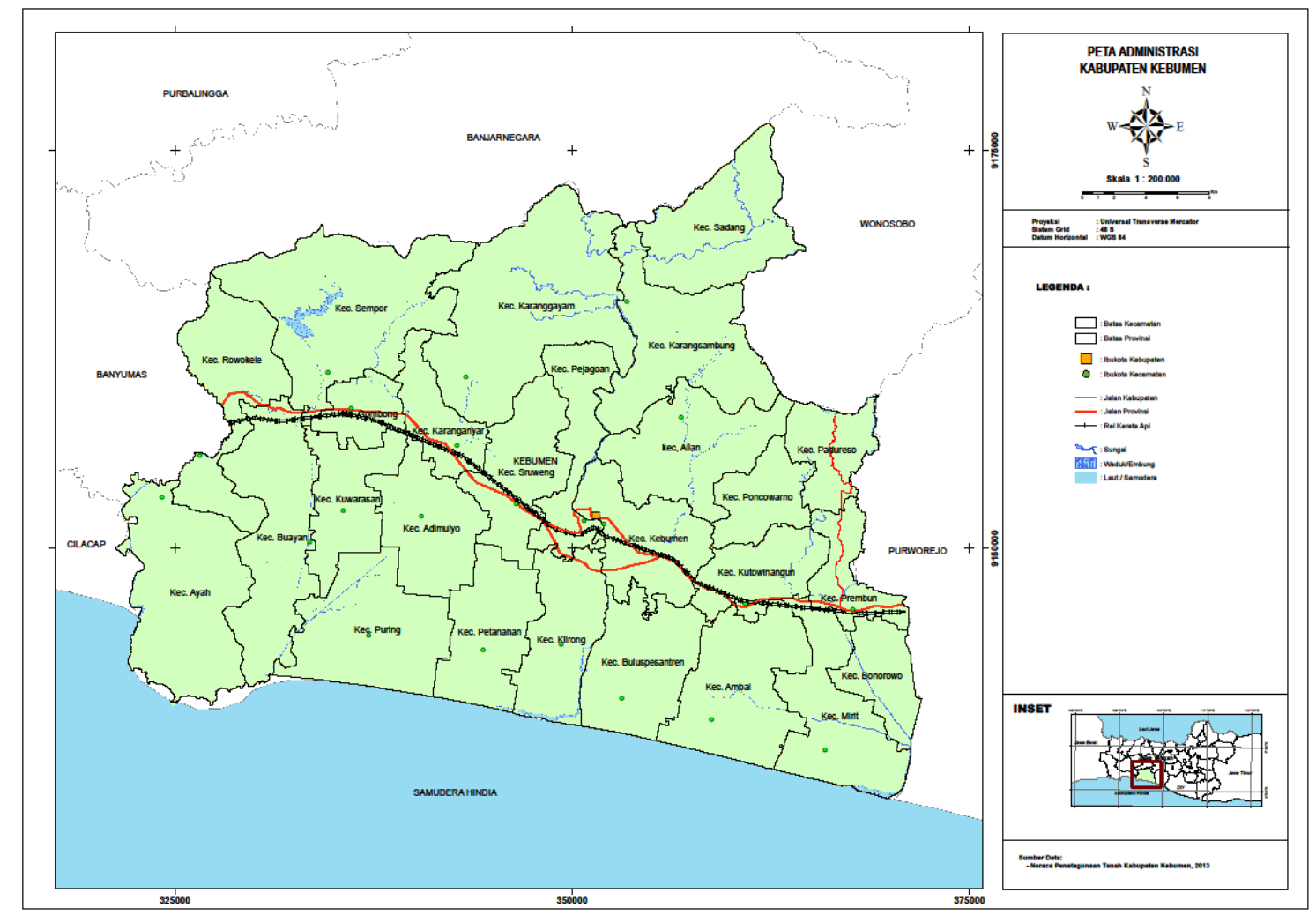

Sumber : Neraca Penatagunaan Tanah Kabupaten Kebumen 2013, Kanwil BPN Prov. Jawa Tengah(diolah) Gambar 2. Peta Administrasi Kabupaten Kebumen

Batas wilayah administrasi Kabupaten Kebumen adalah sebagai berikut:

a. Sebelah Utara berbatasan dengan Kabupaten Wonosobo, Kab. Banjarnegara;

b. Sebelah Timur berbatasan dengan Kabupaten Purworejo;

c. Sebelah Selatan berbatasan dengan Samudera Hindia;

d. Sebelah Barat berbatasan dengan Kabupaten Cilacap, Kabupaten Banjarnegara.

\subsubsection{Kondisi Sosial Ekonomi Wilayah}

Jumlah penduduk di Kabupaten Kebumen adalah sebanyak 1.163.591 jiwa, yang terdiri dari penduduk laki-laki sebanyak 581.947 jiwa (50,01\%) dan penduduk perempuan sebanyak 581.644 jiwa (49,99\%), dengan jumlah KK sebanyak $312.646 \mathrm{KK}$, dan sex ratio sebesar 100\%, yang berarti setiap 100 jiwa penduduk perempuan terdapat 100 jiwa penduduk laki-laki. Penduduk Kabupaten Kebumen mengalami pengurangan sebesar 77.846 jiwa dari Tahun 2008 sebanyak 1.241.437 jiwa sampai Tahun 2012 menjadi sebesar 1.163.591 jiwa, dengan pertumbuhan rata-rata sebesar $0,42 \%$.

Tingkat kepadatan penduduk di Kabupaten Kebumen rata-rata adalah 908 jiwa/Km2. Tiga kecamatan dengan tingkat kepadatan tertinggi berada di Kecamatan Kebumen yaitu sebesar 2.835 jiwa/Km2, Kecamatan Gombong sebesar 2.412 jiwa/Km2, dan Kecamatan Pejagoan sebesar 1.379 jiwa/Km2. Sedangkan kecamatan dengan tingkat kepadatan terendah berada di Kecamatan Sadang yaitu sebesar 332 jiwa/Km2. Sementara kecamatan dengan jumlah penduduk terbanyak adalah di Kecamatan Kebumen yaitu sebanyak 119.163 jiwa, dan 
kecamatan dengan jumlah penduduk terendah berada di Kecamatan Padureso yaitu sebanyak 13.191 jiwa.

Dalam hal ekonomi, tulang punggung perekonomian Kabupaten Kebumen adalah sektor pertanian. Kontribusi sektor ini terhadap PDRB Kabupaten Kebumen atas dasar harga berlaku mencapai 33,60\% dan atas dasar harga konstan tahun 2000 sebesar 36,82\%. Sektor pertanian Kabupaten Kebumen terdiri dari sub sektor tanaman pangan, sub sektor tanaman perkebunan, sub sektor peternakan, sub sektor perikanan dan sub sektor kehutanan.

Padi merupakan komoditi unggulan Kabupaten Kebumen. Sebagai salah satu kabupaten penyangga pangan pokok khususnya padi di Jawa Tengah, produksi padi pada tahun 2011 tercatat sebesar 440.007,10 ton dengan peningkatan sebesar 0,20\% dari tahun sebelumnya. Komoditi lainya berupa tanaman palawija yang meliputi jagung, ketela pohon, ketela rambat, kacang tanah, kacang kedelai dan kacang hijau. Kebumen bahkan menjadi salah satu produsen utama ketela pohon di Jawa Tengah. Potensi tanaman sayuran semusim di Kabupaten Kebumen diantaranya adalah cabe (besar dan rawit), kacang panjang dan kangkung. Sementara untuk tanaman sayuran tahunan, produk utamanya adalah melinjo yang disamping digunakan sebagai sayuran juga banyak dimanfaatkan sebagai bahan baku emping dengan produksi mencapai $143.015 \mathrm{kw}$.

Dari sektor peternakan, jenis ternak yang diusahakan di Kabupaten Kebumen meliputi teknak besar (sapi, kerbau dan kuda), ternak kecil (kambing, domba dan babi) dan unggas (ayam, itik, itik manila, puyuh dan angsa).

\subsubsection{Penggunaan Tanah}

Penggunaan tanah di wilayah Kabupaten Kebumen (berdasarkan data penggunaan tanah tahun terakhir atau 2013) didominasi oleh penggunaan tanah pertanian, yaitu seluas $84.413,45 \mathrm{Ha}(63,34 \%)$, meliputi penggunaan tanah untuk kebun campur seluas $25.828,44 \mathrm{Ha}$ $(19,38 \%)$, sawah 1 kali padi seluas $8.052,46 \mathrm{Ha}(6,04 \%)$, sawah 2 kali padi seluas $36.179 \mathrm{Ha}$ $(27,15 \%)$, tambak seluas $40,17 \mathrm{Ha}(0,03 \%)$ dan tegalan seluas $14.313,38 \mathrm{Ha}(10,74 \%)$. Selain itu terdapat belukar seluas 1.549,39 Ha (1,16\%), hutan seluas 14.293,11 Ha (10,73\%), kampung seluas $30.120,75 \mathrm{Ha}(22,61 \%)$, kuburan seluas $56,36 \mathrm{Ha}(0,04 \%)$, lapangan seluas $22,97 \mathrm{Ha}(0,02 \%)$, pasir seluas $1.112,38 \mathrm{Ha}(0,83 \%)$, rumput seluas $141,84 \mathrm{Ha}(0,11 \%)$, sungai seluas $1.278,30 \mathrm{Ha}(0,96 \%)$ dan waduk seluas 254,99 Ha (0,19\%).

Penggunaan tanah (baru) di Kabupaten Kebumen Tahun 2013 didominasi penggunaan tanah berupa sawah irigasi seluas 44.231,46 Ha (terdiri dari sawah irigasi 1xpadi seluas 8.052,46 Ha dan sawah irigasi 2xpadi seluas $36.179 \mathrm{Ha}$ ). Penggunaan tanah berupa sawah sawah 2xpadi terdapat di seluruh wilayah kecamatan, yang terluas terdapat di Kecamatan Adimulyo seluas 3.199,95 Ha, untuk 1xpadi terdapat di 20 (dua puluh) wilayah kecamatan. Sedangkan penggunaan tanah terkecil untuk tambak yaitu sebesar 0,03 persen.

Tabel 3. Penggunaan Tanah (baru) Kabupaten Kebumen Tahun 2013

\begin{tabular}{|c|l|r|r|}
\hline No & Penggunaan Tanah & \multicolumn{1}{c|}{ Luas (Ha) } & \multicolumn{1}{c|}{ \% Luas Wilayah } \\
\hline 1 & Belukar & $1.549,39$ & 1,16 \\
\hline 2 & Hutan & $14.293,11$ & 10,73 \\
\hline 3 & Kampung & $30.120,75$ & 22,61 \\
\hline
\end{tabular}




\begin{tabular}{|r|l|r|r|}
\hline 4 & Kebun Campuran & $25.828,44$ & 19,38 \\
\hline 5 & Kuburan & 56,36 & 0,04 \\
\hline 6 & Lapangan & 22,97 & 0,02 \\
\hline 7 & Pasir & $1.112,38$ & 0,83 \\
\hline 8 & Rumput & 141,84 & 0,11 \\
\hline 9 & Sawah 1xpadi & $8.052,46$ & 6,04 \\
\hline 10 & Sawah 2xpadi & $36.179,00$ & 27,15 \\
\hline 11 & Sungai & $1.278,30$ & 0,96 \\
\hline 12 & Tambak & 40,17 & 0,03 \\
\hline 13 & Tegalan & $14.313,38$ & 10,74 \\
\hline 14 & Waduk & 254,99 & 0,19 \\
\hline Jumlah & & $\mathbf{1 3 3 . 2 4 3 , 5 5}$ & $\mathbf{1 0 0}$ \\
\hline
\end{tabular}

Sumber : Neraca Penatagunaan tanah Kabipaten Kebumen, 2013, kanwil BPN prov. Jawa Tengah.

\subsubsection{Penguasaan Tanah}

Penguasaan tanah di Kabupaten Kebumen sebagian besar merupakan tanah hak milik, yaitu 111.183,02 Ha atau sebesar $83,44 \%$ dari luas keseluruhan wilayah Kabupaten Kebumen. Tanah yang termasuk ke dalam tanah hak UUPA ini meliputi tanah-tanah dengan jenis penguasaan berupa Hak Milik (HM), Hak Pakai (HP), Hak Guna Bangunan (HGB), Hak Pengelolaan (HP). Selain tanah-tanah dengan hak-hak tersebut di atas, di Kabupaten Kebumen terdapat pula tanah dikelola kehutanan, tanah desa/bengkok dan tanah Negara.

Tabel. 4 Gambaran Umum Penguasaan Tanah Kabupaten Kebumen

\begin{tabular}{|c|l|r|r|}
\hline No. & Penguasaan Tanah & \multicolumn{1}{c|}{ Luas (Ha) } & \% Luas Wilayah \\
\hline 1 & Hak Guna Bangunan & 71,99 & 0,05 \\
\hline 2 & Hak Milik Yasan & $111.049,98$ & 83,34 \\
\hline 3 & Hak Pakai & 52,25 & 0,04 \\
\hline 4 & Hak Pengelolaan & 8,81 & 0,01 \\
\hline 5 & Tanah dikelola Kehutanan & $16.961,94$ & 12,73 \\
\hline 6 & Tanah Desa / Bengkok & $1.632,95$ & 1,23 \\
\hline 7 & Tanah Negara & $1.932,35$ & 1,45 \\
\hline 8 & Waduk & 254,99 & 0,19 \\
\hline 9 & Sungai & $1.278,30$ & 0,96 \\
\hline Jumlah & & $\mathbf{1 3 3 . 2 4 3 , 5 5}$ & $\mathbf{1 0 0}$ \\
\hline
\end{tabular}

Sumber : Neraca Penatagunaan tanah Kabipaten Kebumen, 2013, kanwil BPN prov. Jawa Tengah.

Adapun penyebaran dari masing-masing tanah dengan jenis penguasaan tersebut adalah sebagai berikut:

a. Hak Milik seluas $111.049,98 \mathrm{Ha}(83,34 \%)$, terdapat di seluruh wilayah Kabupaten Kebumen;

b. Hak Pakai seluas $52,25 \mathrm{Ha}(0,04 \%)$, terdapat di Kecamatan Adimulyo, Kecamatan Buluspesantren, Kecamatan Kebumen, Kecamatan Kutowinangun, Kecamatan Pejagoan dan Kecamatan Sempor; 
c. Hak Guna Bangunan seluas $71,99 \mathrm{Ha}$ (0,05\%), terdapat di Kecamatan Buluspesantren, Kecamatan Kebumen, Kecamatan Kutowinangun, Kecamatan Pejagoan, Kecamatan Puring dan Kecamatan Sempor;

d. Hak Pengelolaan seluas 52,25 Ha (0,04\%), terdapat di Kecamatan Adimulyo, Kecamatan Buluspesantren, Kecamatan Kebumen, Kecamatan Kutowinangun, Kecamatan Pejagoan dan Kecamatan Sempor;

e. Tanah dikelola kehutanan seluas $16.961,94 \mathrm{Ha}$ (12,73\%) terdapat di Kecamatan Ayah, Kecamatan Buayan, Kecamatan Karanganyar, Kecamatan Karanggayam, Kecamatan Karangsambung, Kecamatan Paradeso, Kecamatan Pejagoan, Kecamatan Puring, Kecamatan Rowokele, Kecamatan Sadang, Kecamatan Sempor dan Kecamatan Sruweng;

f. Tanah desa/bengkok seluas $1.632,95 \mathrm{Ha}(1,23 \%)$ terdapat di Kecamatan Alian, Kecamatan Adimulyo, Kecamatan Ambal, Kecamatan Ayah, Kecamatan Bonorowo, Kecamatan Buayan, Kecamatan Buluspesantren, Kecamatan Gombong, Kecamatan Karanganyar, Kecamatan Karanggayam, Kecamatan Kebumen, Kecamatan Klirong, Kecamatan Kutowinangun, Kecamatan Kuwarasan, Kecamatan Mirit, Kecamatan Padureso, Kecamatan Pejagoan, Kecamatan Petanahan, Kecamatan Poncowarno, Kecamatan Prembun, Kecamatan Puring, Kecamatan Sempor dan Kecamatan Sruweng.

g. Tanah negara seluas 1.932,35 Ha (1,45\%) terdapat di Kecamatan Ambal, Kecamatan Buluspesantren, Kecamatan Klirong, Kecamatan Mirit, Kecamatan Petanahan dan Kecamatan Puring.

\subsection{Kabupaten Tulungagung}

Kabupaten Tulungagung adalah salah satu kabupaten yang terletak di Provinsi Jawa Timur. Pusat pemerintahannya terletak di Kecamatan Tulungagung dan berlokasi $154 \mathrm{~km}$ barat daya Kota Surabaya, ibu kota Provinsi Jawa Timur. Tulungagung terkenal sebagai satu dari beberapa daerah penghasil marmer terbesar di Indonesia.

Kabupaten Tulungagung kaya akan potensi bahan galian gol C (batu gamping, marmer dan fosfat) membuat daerah ini berkembang menjadi sentra industri kerajinan marner dan onix. Kabupaten Tulungagung untuk mengelola sumber daya alam dan sumber daya manusia yang potensial, telah mengantarkan Tulungagung sebagai kota penghasil kerajinan marmer dan onix yang dikenal dunia, hingga ke benua asia dan eropa.

Desa Besole merupakan penghasil kerajinan marmer dan onix terbesar, dengan hasil produksi sebanyak 24.151 unit per bulan. Marmer, Onyx dan Batu Fosil, deposit marmer berada di Desa Besole Kecamatan Besuki, Desa Ngentrong dan Desa Gamping Kecamatan Campurdarat, serta Desa Sukorejo Kecamatan Bandung, jumlah cadangan $\pm 4.322 .500 \mathrm{~m}^{3}$. Kabupaten Tulungagung yang didominasi oleh struktur batuan yang beraneka ragam membuat daerah ini kaya akan potensi bahan galian gol. C (batu gamping, marmer dan fosfat) membuat daerah ini berkembang menjadi sentra industri kerajinan marner dan onix. 


\subsubsection{Kondisi Geografis Wilayah}

Secara geografis Kabupaten Tulungagung terletak pada $111^{\circ} 43^{\prime}$ sampai dengan $112^{\circ}$ $07^{\prime}$ Bujur Timur $7^{0} \quad 51^{\prime}$ sampai dengan $8^{0}$ 18' Lintang Selatan dengan batas - batas administrasi wilayah sebagai berikut :

- Sebelah Utara : :Kabupaten Kediri.

- Sebelah Timur : :Kabupaten Blitar.

- Sebelah Selatan :Samudera Indonesia.

- Sebelah Barat $\quad$ :Kabupaten Trenggalek.

Pembagian administrasi Kabupaten Tulungagung terdiri atas 19 kecamatan 257 desa, dan 14 kelurahan. Untuk lebih jelas kesembilan belas kecamatan dapat dilihat pada tabel 1 berikut yang diambil dari Neraca Penatagunaan Tanah Kabupaten Tulungagung Tahun 2011:

Tabel 5. Pembagian Wilayah Kecamatan di Kab. Tulungagung

\begin{tabular}{|l|l|r|r|}
\hline \multirow{2}{*}{ No } & \multirow{2}{*}{ Kecamatan } & \multicolumn{2}{|c|}{ Lua } \\
\cline { 3 - 4 } & & $4.695,93$ & \% Wilayah \\
\hline 1 & BANDUNG & $9.287,99$ & 4,08 \\
\hline 2 & BESUKI & $3.765,02$ & 8,07 \\
\hline 3 & BOYOLANGU & $4.470,27$ & 3,27 \\
\hline 4 & CAMPURDARAT & $4.338,86$ & 3,89 \\
\hline 5 & GONDANG & $11.369,18$ & 3,77 \\
\hline 6 & KALIDAWIR & $3.800,84$ & 9,88 \\
\hline 7 & KARANGREJO & $2.900,53$ & 3,30 \\
\hline 8 & KAUMAN & $3.392,56$ & 2,52 \\
\hline 9 & KEDUNGWARU & $4.142,92$ & 2,95 \\
\hline 10 & NGANTRU & $3.908,82$ & 3,60 \\
\hline 11 & NGUNUT & $10.906,62$ & 3,40 \\
\hline 12 & PAGERWOJO & $3.811,79$ & 9,48 \\
\hline 13 & PAKEL & $7.787,19$ & 3,31 \\
\hline 14 & PUCANGLABAN & $7.589,84$ & 6,77 \\
\hline 15 & REJOTANGAN & $12.150,79$ & 6,60 \\
\hline 16 & SENDANG & $4.180,92$ & 10,56 \\
\hline 17 & SUMBERGEMPOL & $11.474,37$ & 3,63 \\
\hline 18 & TANGGUNGGUNUNG & $1.085,69$ & 9,97 \\
\hline 19 & TULUNGAGUNG & $\mathbf{1 1 5 . 0 6 0 , 1 1}$ & $\mathbf{1 0 0 , 0 0}$ \\
\hline & TOTAL & & \\
\hline Sumber $:$ Kanwil BPN Propinsi Jawa Timur & & \\
\hline
\end{tabular}




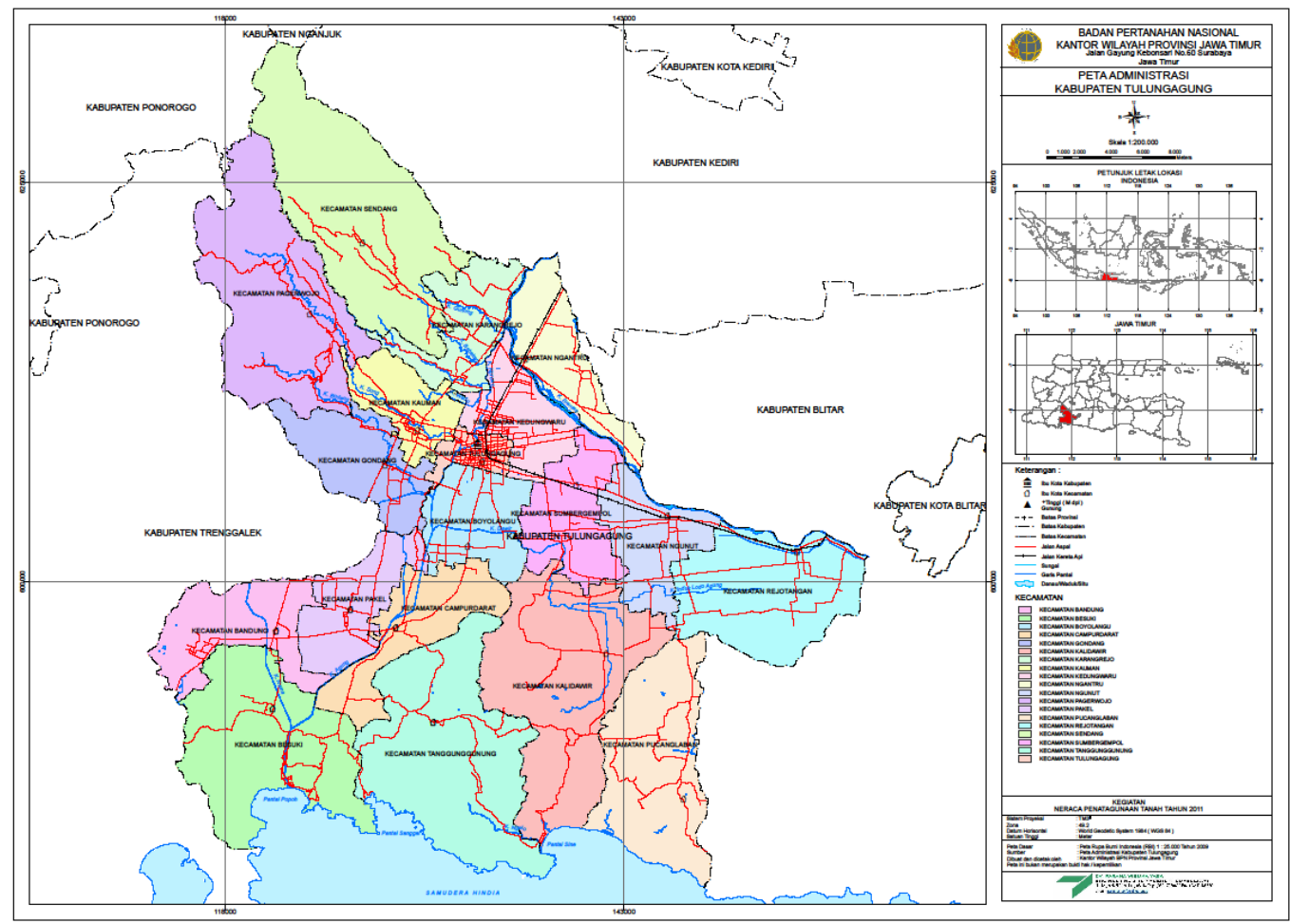

Sumber : Kanwil BPN Propinsi Jawa Timur

Gambar 3. Peta Administrasi Kabupaten Tulungagung

Dalam hal kependudukan tercatat pada akhir 2006 jumlah penduduk di Kabupaten Tulungagung tercatat sebanyak 1.002 .807 jiwa yang terbagi atas laki-laki 498.533 (49,71\%) jiwa dan perempuan $504.274(50,29 \%) .{ }^{11}$ Sedangkan menurut hasil registrasi penduduk akhir tahun 2012 berjumlah 1.048 .472 jiwa di tahun 2012, yang terbagi atas laki-laki 523.788 jiwa dan perempuan 524.684 jiwa dengan tingkat kepadatan penduduk rata-rata 993 jiwa/km2 . ${ }^{12}$ Kepadatan penduduk terkonsentrasi pada tiga kecamatan yaitu Kecamatan Tulungagung, Kecamatan Kedungwaru, dan Kecamatan Boyolangu.

\subsubsection{Kondisi Sosial Ekonomi Wilayah}

Sebagaimana tingkat kepadatan penduduknya, pembangunan Kabupaten Tulungagung juga terkonsentrasi di ketiga kecamatan tersebut. Pembangunan yang dimaksud disini adalah pembangunan yang berkaitan dengan pembangunan pemerintahan, pendidikan, perdagangan dan jasa. Kecamatan Tulungagung sebagai pusat Kabupaten Tulungagung sebagai pusat pemerintahan, sedangkan Kecamatan Kedungwaru dan Kecamatan Boyolangu sebagai pusat pendidikan, perdagangan dan jasa sedangkan kecamatan selain ketiga kecamatan tersebut dilakukan pengembangan pada bidang industri kecil, industri menengah dan industri besar serta sebagai pusat pengembangan pada sektor perikanan, pertambangan dan pusat sektor pertanian.

\footnotetext{
11 https://id.wikipedia.org/wiki/Kabupaten_Tulungagung
}

12 Tulungagung dalam Angka 2013, 
Sektor pertanian merupakan sektor utama perekonomian di Kabupaten Tulungagung. Peranan sektor pertanian berdasarkan kontribusinya dalam Produk Domestik Regional Bruto (PDRB)terlihat dalam hal penyerapan tenaga kerja. Jenis pertanian Tanaman Pangan yang ada di Kabupaten Tulungagung antara lain adalah padi, jagung, dan kedelai.

Sektor lain yang mendukung perekonomian Kabupaten Tulungagung adalah pariwisata. Wisata yang banyak dikembangkan adalah wisata pantai dikarenakan Kabupaten Tulungagung dikaruniai wilayah pantai yang luas di sebelah selatan. Beberapa pantai yang cukup terkenal adalah Pantai Popoh, Pantai Sidem, Pantai, Coro, Pantai Sine, Pantai Brumbun, Pantai Sanggar, Pantai Patuk Gebak serta pantai-pantai baru yang banyak ditemukan.

Dalam hal perindustrian Kabupaten Tulungung terkenal dengan industri batu marmer. Kabupaten ini merupakan penghasil marmer yang terbesar di Indonesia bahkan aset industri marmer telah menembus pasar Internasional. Sehingga industri batu marmer dapat menjadi potensi yang baik untuk perekonomian Kabupaten Tulungagung karena industri marmer merupakan salah satu komoditi ekspor antar negara dengan omset per tahun mencapai 850 juta rupiah. ${ }^{13}$

\subsubsection{Penggunaan Tanah}

Wilayah Kabupaten Tulungagung sebagian besar penggunaan tanahnya adalah kegiatan budidaya tanah pertanian yaitu sawah irigasi seluas $20.610 \mathrm{Ha}(29,21 \%)$. Sementara kawasan non budidaya terdiri dari kawasan hutan $(3,6 \%)$ dan padang $(3,9 \%)$. Penggunaan tanah budidaya non pertanian dengan luasan terbesar adalah permukiman yaitu 14.157,9 $\mathrm{Ha}$ atau $20,06 \%$ dari luas wilayah Kabupaten Tulungagung. Secara spasial pola ruang sama seperti kondisi pada tahun 2009, sebagian besar orientasi penduduk masih berpusat pada bagian tengah wilayah yaitu Kecamatan Tulungagung.

Tabel 6. Penggunaan Tanah Tahun 2011

\begin{tabular}{|l|l|r|r|}
\hline No & Penggunaan Tanah & \multicolumn{1}{c|}{ Luas (ha) } & \% Luas Wilayah \\
\hline 1 & Hutan & $18.130,48$ & 15,76 \\
\hline 2 & Permukiman & $22.294,53$ & 19,38 \\
\hline 3 & Kebun & $20.085,24$ & 17,46 \\
\hline 4 & Padang & $10.473,26$ & 9,10 \\
\hline 5 & Sawah Irigasi & $23.552,49$ & 20,47 \\
\hline 6 & Sawah Tadah Hujan & $6.617,24$ & 5,75 \\
\hline 7 & Tanah Jasa & 60,53 & 0,05 \\
\hline 8 & Tegalan/Ladang & $10.743,00$ & 9,34 \\
\hline 9 & Kolam Air Tawar & 2,00 & 0,00 \\
\hline 10 & Sungai/Danau & 927,42 & 0,81 \\
\hline 11 & Tanah Terbuka & 29,83 & 0,03 \\
\hline 12 & Perkebunan & $2.144,12$ & 1,86 \\
\hline & Total & $\mathbf{1 1 5 . 0 6 0 , 1 1}$ & $\mathbf{1 0 0}$ \\
\hline
\end{tabular}

Sumber : Kanwil BPN Propinsi Jawa Timur

\footnotetext{
${ }^{13} \mathrm{http}: / /$ puspakrtika.blogspot.co.id/
} 


\subsubsection{Penguasaan Tanah}

Gambaran penguasaan tanah di Kabupaten Tulungagung tahun 2011, sebagian besar wilayahnya merupakan tanah negara dikuasai dan hak milik. Tanah negara dikuasai $(40,64 \%)$ dengan luasan terbesar berada di Kecamatan Tanggunggunung seluas 9.566,79 $\mathrm{Ha}$ dan Pagerwojo seluas $8.595,4 \mathrm{Ha}$. Sementara itu pada tanah hak milik (40\%) luasan terbesar berada di Kecamatan Kalidawir seluas $3.839 \mathrm{Ha}$. Pada tanah hak adat, wilayah terluas berada di Kecamatan Pucanglaban dengan 3.405,6 Ha, dan penguasaan hak guna usaha terluas 620 Ha terdapat di Kecamatan Pucanglaban.

Tabel 7. Penguasaan Tanah Kabupaten Tulungagung

\begin{tabular}{|c|l|r|r|}
\hline No & Gambaran Umum Penguasaan Tanah & \multicolumn{1}{c|}{ Luas (ha) } & $\begin{array}{c}\text { \% Luas } \\
\text { Wilayah }\end{array}$ \\
\hline 1 & Hak Adat & $18.471,804$ & 16,05 \\
\hline 2 & Hak Milik & $46.020,576$ & 40,00 \\
\hline 3 & Tanah Negara Dikuasai & $46.758,186$ & 40,64 \\
\hline 4 & Sungai/Danau & 927,415 & 0,81 \\
\hline 5 & Hak Guna Usaha & $2.882,133$ & 2,50 \\
\hline & $\quad$ Total & $\mathbf{1 1 5 . 0 6 0 , 1 1 4}$ & $\mathbf{1 0 0 , 0 0}$ \\
\hline
\end{tabular}

Sumber : Kanwil BPN Propinsi Jawa Timur

\subsection{Kabupaten Pasuruan}

Kawasan Pasuruan merupakan kawasan pertanian dan perdagangan sejak periode klasik Indonesia. Pelabuhan Pasuruan telah melayani perdagangan untuk kerajaan-kerajaan di Jawa Timur. Pada masa penguasaan oleh VOC (diserahkan dari wilayah Kesultanan Mataram sebagai imbalan bantuan VOC dalam perang Suksesi Jawa, Pasuruan menjadi salah satu penghasil utama komoditas perdagangan hasil pertanian. Hal ini diteruskan pada periode penguasaan oleh Hindia Belanda. ${ }^{14}$ Sedangkan saat ini Kabupaten Pasuruan dikenal sebagai daerah perindustrian, pertanian, dan tujuan wisata. Kompleks pegunungan Tengger dengan Gunung Bromo merupakan atraksi wisata utama di Kabupaten Pasuruan. Wilayah timur Kabupaten Pasuruan termasuk ke dalam wilayah Tapal Kuda, Jawa Timur. Pusat pemerintah Kabupaten Pasuruan berlokasi di Bangil dengan penetapan pemerintah melalui PP No 26 Tahun 2016.

\subsubsection{Kondisi Fisik Wilayah}

Kabupaten Pasuruan terletak pada koordinat $112^{\circ} 33^{\circ} 55^{\prime \prime}$ hingga 113030 $37^{\prime \prime}$ Bujur Timur dan antara $7^{0} 32^{\prime} 34^{\prime \prime}$ hingga $8^{\circ} 30^{\prime} 20^{\prime \prime}$ Lintang Selatan. Letak geografis wilayah Daerah Tingkat II Kabupaten Pasuruan berada pada posisi sangat strategis yaitu jalur regional dan jalur utama perekonomian Surabaya - Malang dan Surabaya - Banyuwangi. Adapun batas administrasinya adalah sebagai berikut : ${ }^{15}$

- Sebelah Utara: Kabupaten Sidoarjo, Kota Pasuruan dan Selat Madura

- Sebelah Timur : Kabupaten Probolinggo

\footnotetext{
14 https://id.wikipedia.org/wiki/Kabupaten_Pasuruan

${ }^{15}$ Neraca Penatagunaan Tanah kabupaten Pasuruan tahun 2013, Kanwil BPN Provinsi Jawa Timur.
} 
- Sebelah Selatan : Kabupaten Malang

- Sebelah Barat : Kota Mojokerto

Secara administrasi wilayah Kabupaten Pasuruan terbagi atas 24 wilayah Kecamatan, 341 wilayah Desa, 24 wilayah Keluarahan. Tabel berikut menunjukan pembagian administrasi kabupaten Pasuruan per kecamatan, yang diambil dari laporan Neraca penatagunaan Tanah tahun 2013:

Tabel 8. Jumlah Kecamatan dan Luas Kabupaten Pasuruan

\begin{tabular}{|r|l|r|r|}
\hline \multirow{2}{*}{ No } & \multirow{2}{*}{ Kecamatan } & \multicolumn{2}{|c|}{ Luas } \\
\cline { 3 - 4 } & & \multicolumn{1}{c|}{ Ha } & \multicolumn{1}{c|}{ \% Wilayah } \\
\hline 1 & Bangil & $4.332,80$ & 2,92 \\
\hline 2 & Beji & $3.914,34$ & 2,63 \\
\hline 3 & Gempol & $6.048,41$ & 4,07 \\
\hline 4 & Gondang Wetan & $2.699,34$ & 1,82 \\
\hline 5 & Grati & $4.673,24$ & 3,15 \\
\hline 6 & Kajayan & $7.995,88$ & 5,38 \\
\hline 7 & Kraton & $5.614,63$ & 3,78 \\
\hline 8 & Lekok & $4.768,07$ & 3,21 \\
\hline 9 & Lumbang & $12.279,99$ & 8,26 \\
\hline 10 & Nguling & $4.533,57$ & 3,05 \\
\hline 11 & Pandaan & $4.357,87$ & 2,93 \\
\hline 12 & Pasrepan & $8.342,02$ & 5,61 \\
\hline 13 & Pohjentrek & $1.255,75$ & 0,85 \\
\hline 14 & Prigen & $13.141,07$ & 8,84 \\
\hline 15 & Purwodadi & $9.083,83$ & 6,11 \\
\hline 16 & Purwosari & $7.457,53$ & 5,02 \\
\hline 17 & Puspo & $7.191,14$ & 4,84 \\
\hline 18 & Rejoso & $3.527,11$ & 2,37 \\
\hline 19 & Rembang & $5.718,92$ & 3,85 \\
\hline 20 & Sukorejo & $5.810,69$ & 3,91 \\
\hline 21 & Tosari & $8.157,39$ & 5,49 \\
\hline 22 & Tutur & $9.021,93$ & 6,07 \\
\hline 23 & Winongan & $4.292,34$ & 2,89 \\
\hline 24 & Wonorejo & $\mathbf{1 4 8 . 5 8 0 . 7 4}$ & $\mathbf{1 0 0 , 0 0}$ \\
\hline & TOTAL & & \\
\hline
\end{tabular}

Sumber : Kanwil BPN Propinsi Jawa Timur 


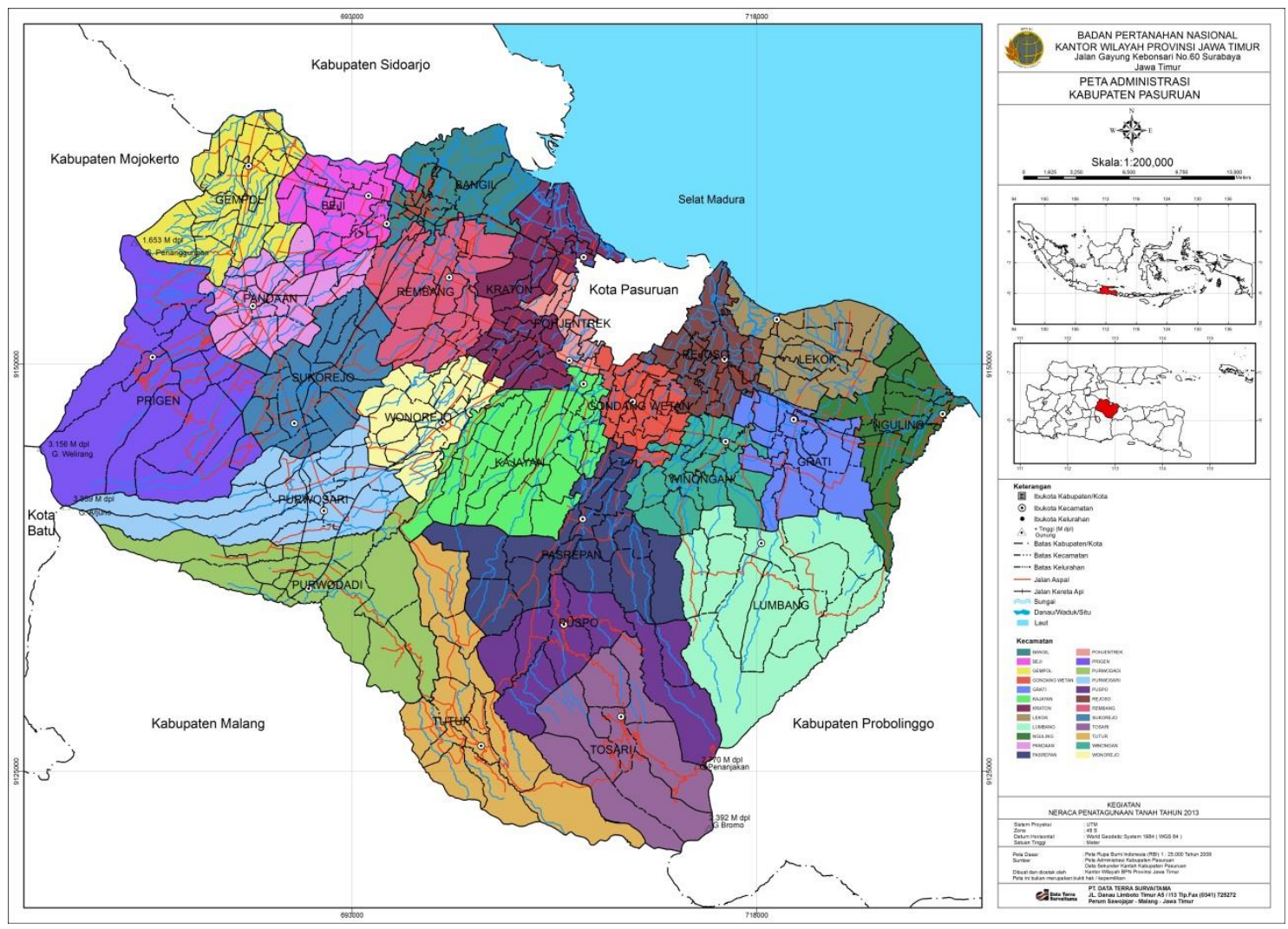

Sumber : Kanwil BPN Propinsi Jawa Timur

Gambar 4. Peta Administrasi Kabupaten Pasuruan

\subsubsection{Kondisi Sosial Ekonomi}

Jumlah penduduk Kabupaten Pasuruan berdasar data pada Neraca Penatagunaan Tanah dari Kanwil BPN Provinsi Jawa Timur tahun 2013 adalah 1.520.978 Jiwa. Kecamatan dengan jumlah penduduk terbanyak adalah Kecamatan Gempol dengan penduduk sebanyak 124.162 jiwa, sedangkan kecamatan dengan penduduk paling sedikit adalah Kecamatan Tosari, dengan penduduk sebanyak 18.485 jiwa. Lebih jelasnya bisa dilihat pada gambar 2 dibawah ini.

Dalam hal tingkat kepadatan penduduk, kepadatan tertinggi berada Kecamatan Pandaan yaitu $24 \mathrm{jiwa} / \mathrm{Ha}$, berikutnya adalah Kecamatan Pohjentrek dengan $23 \mathrm{jiwa} / \mathrm{Ha}$. Sementara wilayah dengan kepadatan terendah pada wilayah Kecamatan Tosari yaitu $2 \mathrm{jiwa} / \mathrm{Ha}$. 


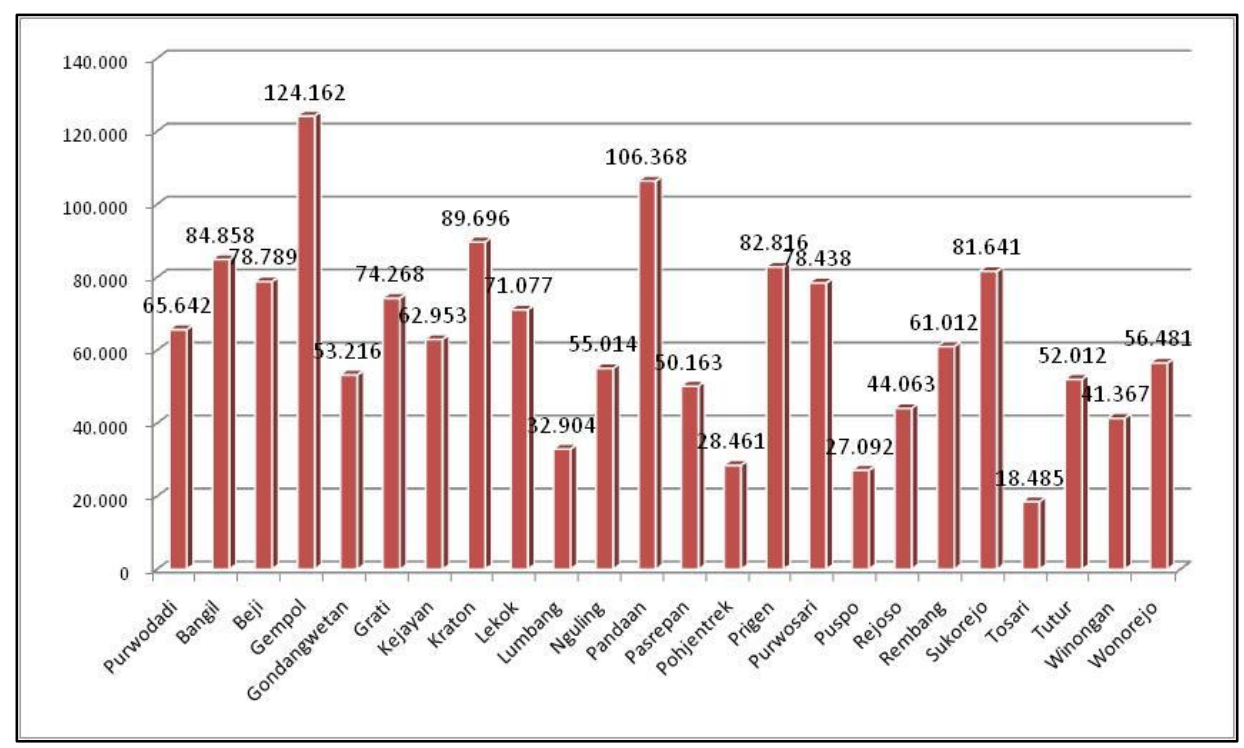

Sumber : Kanwil BPN Propinsi Jawa Timur

Gambar 5. Diagram Jumlah Penduduk Kabupaten Pasuruan

Dari segi perekonomian, berdasarkan kontribusi masing-masing sektor dan sub sektor ekonomi di wilayah Kabupaten Pasuruan selama tahun terakhir ini dari seluruh sektor dan sub sektor yang ada, dapat diidentifikasikan 3 (tiga) sektor yang berpotensi dengan kontribusi terbesar meliputi sektor tanaman bahan makanan $21,71 \%$, industri pengolahan makanan, minuman dan tembakau sebesar 19,35\%, serta perdagangan dengan kontribusi sebesar 12,36\%. Adapun berdasarkan tingkat pertumbuhannya dalam 3 tahun terakhir, maka sektor angkutan dan komunikasi, bangunan, serta industri pengolahan merupakan sektor dengan tingkat pertumbuhan paling tinggi.

\subsubsection{Penggunaan Tanah}

Kabupaten Pasuruan sebagian besar penggunaan tanahnya adalah kegiatan budidaya pertanian yaitu sawah seluas 50.828,45 Ha (34,2\%), perkebunan 12.506,75 Ha (8,4\%), perikanan 1,99 Ha dan budidaya pertanian lainnya seluas 37.332.03 Ha. Sementara kawasan budidaya non-pertanian berupa perumahan seluas 16.152,38 Ha (10,9\%), industri 3.063,45 Ha (2,06\%), pertambangan 126,52 Ha dan budidaya non-pertanian lainnya 604,48 Ha. Sedangkan Penggunaan tanah non budidaya dengan luasan terbesar adalah hutan yaitu 16.785,09 $\mathrm{Ha}$ atau $11,29 \%$ dari luas wilayah Kabupaten Pasuruan.

Tabel 9. Penggunaan Tanah Kabupaten Pasuruan Tahun 2013

\begin{tabular}{|c|l|r|r|}
\hline No & \multicolumn{1}{|c|}{ Penggunaan Tanah } & \multicolumn{1}{c|}{ Luas (Ha) } & \multicolumn{1}{c|}{$\begin{array}{c}\text { Luas } \\
\text { Wilayah }\end{array}$} \\
\hline 1 & Danau & 188,71 & 0,13 \\
\hline 2 & Hutan & $17.549,76$ & 11,81 \\
\hline 3 & Industri & 319,44 & 0,21 \\
\hline 4 & Padang & $5.472,75$ & 3,68 \\
\hline 5 & Perairan darat & $4.386,85$ & 2,95 \\
\hline 6 & Perkebunan & $12.218,50$ & 8,22 \\
\hline 7 & Permukiman & $15.840,97$ & 10,66 \\
\hline
\end{tabular}




\begin{tabular}{|c|l|r|r|}
\hline 8 & Persawahan & $1.554,76$ & 1,05 \\
\hline 9 & Pertanian tanah kering semusim & $38.646,44$ & 26,01 \\
\hline 10 & Sungai & 75,85 & 0,05 \\
\hline 11 & Tanah Terbuka & $52.307,58$ & 35,20 \\
\hline 12 & Waduk & 19,01 & 0,01 \\
\hline & Total & $\mathbf{1 4 8 . 5 8 0 , 6 2}$ & $\mathbf{1 0 0 , 0 0}$ \\
\hline
\end{tabular}

Sumber : Kanwil BPN Propinsi Jawa Timur

\subsubsection{Penguasaan Tanah}

Gambaran penguasaan tanah di Kabupaten Pasuruan tahun 2013 adalah sebagian besar wilayahnya merupakan tanah milik adat/ulayat. Penguasaan tanah milik adat/ulayat dengan luas $125.110,4 \mathrm{Ha}(84,2 \%)$ dengan luasan terbesar berada di Kecamatan Kajayan (7.555,02 Ha). Sementara itu pada tanah Negara dikuasai $(13,55 \%)$ luasan terbesar berada di Kecamatan Prigen (6408,545 Ha). Selengkapnya mengenai sebaran luasan penguasaan tanah di Kabupaten Pasuruan dapat dilihat pada Lampiran tentang rincian penguasaan tanah tahun 2013 Kabupaten Pasuruan.

Adapun penguasaan tanah di Kabupaten Pasuruan didominasi oleh tanah milik adat/ulayat yang tersebar di semua kecamatan di Kabupaten Pasuruan. Sedangkan untuk tanah negara dikuasai tersebar pada bagian selatan, barat dan tengah. Tepatnya terletak di Kecamatan Gempol, Pasrepan, Kejayan dan Purwodadi.

Tabel 10. Penguasaan Tanah Kabupaten Pasuruan Tahun 2013

\begin{tabular}{|c|l|r|r|}
\hline No & \multicolumn{1}{|c|}{$\begin{array}{c}\text { Gambaran Umum Penguasaan } \\
\text { Tanah }\end{array}$} & \multicolumn{1}{c|}{ Luas (Ha) } & \multicolumn{1}{c|}{ \% Wilayah } \\
\hline 1 & Hak Guna Bangunan & $3.063,48$ & 2,06 \\
\hline 2 & Sungai/Danau & 276,73 & 0,19 \\
\hline 3 & Tanah Milik,Adat/Ulayat,UUPA & $125.110,40$ & 84,20 \\
\hline 4 & Tanah Negara Dikuasai & $20.134,59$ & 13,55 \\
\hline & \multicolumn{1}{|c|}{ Total } & $\mathbf{1 4 8 . 5 8 5 , 2}$ & $\mathbf{1 0 0}$ \\
\hline
\end{tabular}

Sumber : Kanwil BPN Propinsi Jawa Timur

\subsection{Kota Pasuruan}

Sebagaimana dikutip dari situs resmi Kota Pasuruan, secara legalitas formal, kepastian mulai adanya Pemerintah Kota Pasuruan adalah setelah dibentuknya Residensi Pasuruan pada 1 Januari 1901 oleh Pemerintah Hindia Belanda. Kemudian ditindaklanjuti pembentukan Kota Praja (Gementee) Pasuruan seperti termaktub dalam Staatblat 1918 No. 320 dengan nama Stads Gementee van Pasoeroean pada tanggal 20 Juni 1918. Semasa Presiden Soekarno, Pasuruan dinyatakan sebagai Kotamadya dengan wilayah kekuasaan terdiri dari tiga desa dan satu kecamatan. Pada 21 Desember 1982 Kotamadya Pasuruan diperluas menjadi 3 kecamatan dengan 19 kelurahan dan 15 desa.

Sementara di masa lalu Pasuruan dikenal dengan nama 'Paravan' Orang Tionghoa menyebut Pasuruan sebagai Yanwang atau Basuluan. Ada juga yang menyandingkan nama Pasuruan dengan kata 'Pasar dan 'Oeang'. Ini tidak lepas dari ramainya perdagangan di 
Pasuruan dengan adanya Pelabuhan Tanjung Tembikar, sehingga mampu menarik banyak kaum pedagang untuk datang ke Pasuruan. Berkat pelabuhan ini pulalah di masa lalu Kota Pasuruan menjadi salah satu pusat terjadinya transaksi dagang antar pulau di kawasan timur nusantara. ${ }^{16}$

\subsubsection{Kondisi Fisik Wilayah}

Kota Pasuruan termasuk salah satu Kota di Provinsi Jawa Timur yang terletak pada koordinat $112^{0} 45^{\prime}-112^{0} 55^{\prime}$ Bujur Timur dan $7^{0} 35^{\prime}-7^{\circ} 45^{\prime}$ Lintang Selatan dan berjarak sekitar 40 Km di sebelah timur laut Ibukota Provinsi Jawa Timur. Secara administrasi, Kota Pasuruan dikelilingi oleh Kabupaten Pasuruan kecuali bagian sebelah utara yang berada di Pantai Selatan Madura. Adapun batas administrasinya adalah sebagai berikut $:^{17}$

- Sebelah Utara : Selat Madura

- Sebelah Timur : Kecamatan Rejoso Kabupaten Pasuruan

- Sebelah Selatan : Kecamatan Pohjentrek Kabupaten Pasuruan

- Sebelah Barat : Kecamatan Kraton Kabupaten Pasuruan

Kota Pasuruan terdiri atas empat kecamatan seperti dapat dilihat pada tabel berikut:

Tabel 10. Jumlah Kecamatan dan Jumlah Kelurahan di Kota Pasuruan

\begin{tabular}{|c|l|c|}
\hline No & \multicolumn{1}{|c|}{ Kecamatan } & $\begin{array}{c}\text { Jumlah } \\
\text { Kelurahan }\end{array}$ \\
\hline 1 & Purworejo & 7 \\
\hline 2 & Bugul Kidul & 6 \\
\hline 3 & Gadingrejo & 8 \\
\hline 4 & Panggungrejo & 13 \\
\hline & TOTAL & $\mathbf{3 4}$ \\
\hline
\end{tabular}

Sumber : http://pasuruankota.go.id/menu/80.html

\footnotetext{
16 http://pasuruankota.go.id/menu/80.html

${ }^{17}$ Neraca Penatagunaan Tanah Kota Pasuruan Tahun 2013, kanwil BPN Provinsi Jawa Timur
} 


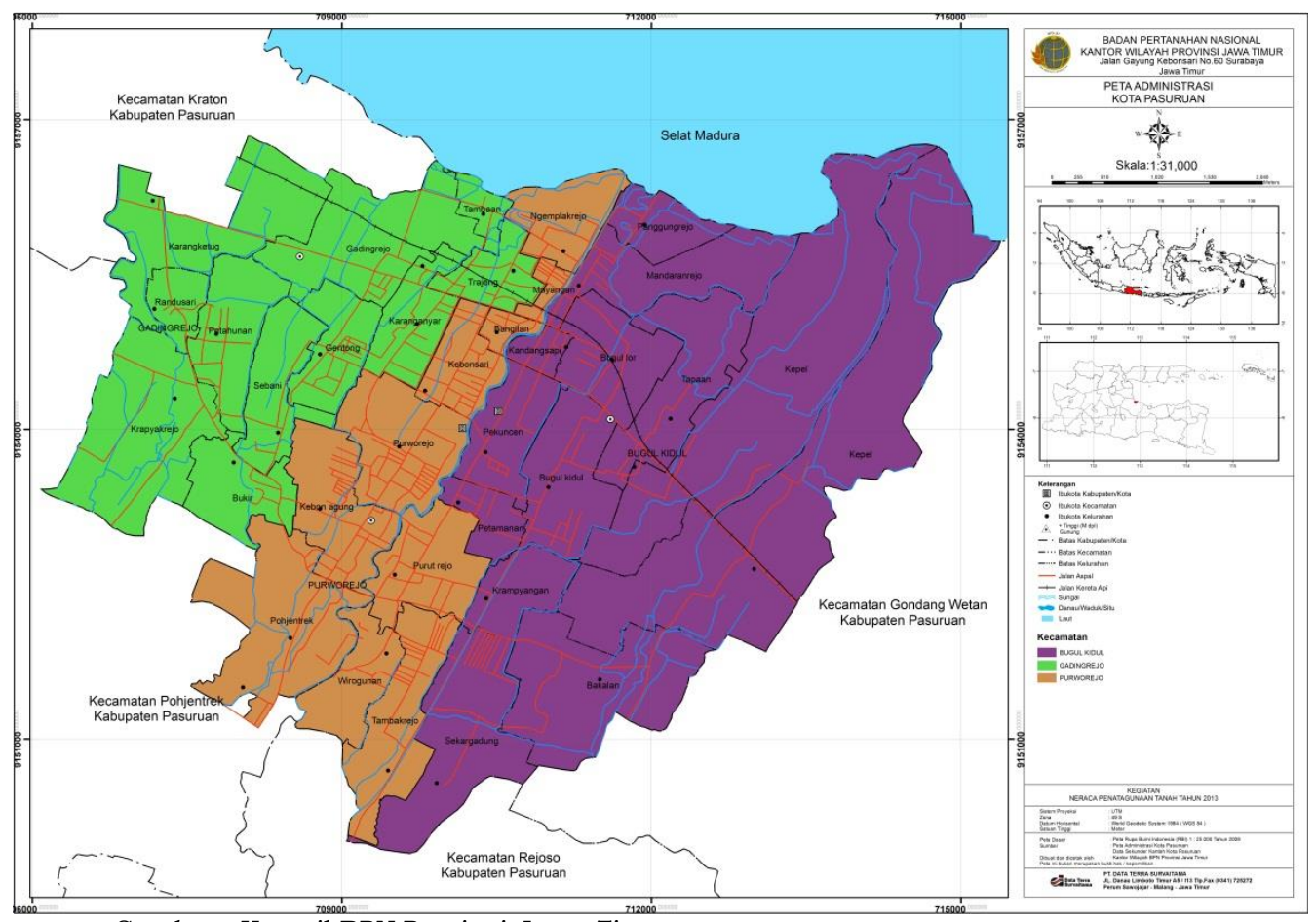

Sumber : Kanwil BPN Propinsi Jawa Timur

Gambar 6. Peta Administrasi Kota Pasuruan

Gambar diatas menunjukan wilayah administrasi Kota Pasuruan yang masih terdiri dari tiga kecamatan sebelum Pemekaran Kecamatan Kandangsapi dari Kecamatan Bugul Kidul. Selanjutnya, atas aspirasi dari warga masyarakat nama Kandangsapi diganti menjadi Panggungrejo yang memiliki arti "tempat yang tinggi” .

\subsubsection{Kondisi Sosial Ekonomi Wilayah}

Jumlah penduduk Kota Pasuruan berdasarkan data dari Dinas Kependudukan dan Pencatatan Sipil pada tahun 2013 adalah sebanyak 208.079 jiwa dengan kepadatan penduduk sekitar $\pm 5.091 \mathrm{jiwa} / \mathrm{km}^{2}$. Kecamatan Panggung Rejo merupakan Wilayah dengan penduduk terbanyak sedangkan Bugul Kidul memiliki penduduk paling sedikit. Berikut adalah penduduk Kota Pasuruan per Kecamatan tahun 2012: ${ }^{18}$

a. Kecamatan Gadingrejo : 45.581 jiwa

b. Kecamatan Purworejo : 58.120 jiwa

c. Kecamatan Bugulkidul : 30.839 jiwa

d. Kecamatan Panggungrejo :73.537 jiwa

Dari sisi perekonomian, Kota Pasuruan masih memiliki lahan pertanian yang masih tergolong produktif. Budidaya tanaman pertanian Kota Pasuruan lebih banyak ditanami padi dan sebagian kedelai. Untuk lahan produksi perkebunan di Kota Pasuruan meliputi buahbuahan, tebu dan randu. Dalam hal peternakan hasil produksi terbesarnya adalah sapi yang diambil daging, kulit dan susunya. Dalam bidang perikanan diketahui hasil perikanan Kota

${ }^{18}$ https://id.wikipedia.org/wiki/Kota_Pasuruan 
Pasuruan dibedakan menjadi dua yaitu ikan laut dan ikan darat. Dari hasil produksi ikan laut tertinggi adalah ikan tembeng sedangkan hasil produksi ikan darat tertinggi adalah ikan bandeng.

Industri yang terdapat di Kota Pasuruan dibedakan menjadi dua yaitu industri kimia agro dan hasil hutan dan industri logam mesin elektronika dan aneka. Dari masing-masing industri tersebut masih dibedakan menjadi dua lagi yaitu formal dan non formal. Mayoritas industri yang terdapat di Kota Pasuruan adalah industri industri kimia agro dan hasil hutan sebesar 2.295 buah terdiri dari 468 buah formal dan 1827 buah. $^{19}$

\subsubsection{Penggunaan Tanah}

Hasil updating data di lapangan oleh Kantor Wilayah Badan Pertanahan Propinsi Jawa Timur dengan peta dasar yaitu peta rupabumi Indonesia, wilayah Kota Pasuruan sebagian besar penggunaan tanahnya adalah kegiatan budidaya pertanian yaitu sawah seluas 1491,2 Ha (39\%), perkebunan 55,4 Ha (1,5\%) dan budidaya pertanian lainnya seluas 10,3 Ha. Sementara kawasan budidaya non-pertanian berupa perumahan seluas 1069,7 Ha (28,1\%), industry 127,6 $\mathrm{Ha}(3,4 \%)$, jasa $148,8 \mathrm{Ha}$ dan budidaya non-pertanian lainnya $102,7 \mathrm{Ha}$. Sedangkan Penggunaan tanah non budidaya dengan luasan terbesar adalah tanah terbuka yaitu $69 \mathrm{Ha}$ atau $1,7 \%$ dari luas wilayah Kota Pasuruan. Pola ruang sama seperti kondisi pada tahun 2009, sebagian besar orientasi penduduk masih berpusat pada bagian tengah wilayah dengan menginfiltrasi ruang kosong kota menjadi lahan terbangun yang termasuk dalam wilayah Kecamatan Purworejo.

Tabel 11. Penggunaan Tanah Kota Pasuruan Tahun 2013

\begin{tabular}{|l|l|r|r|}
\hline No & \multicolumn{1}{|c|}{ Penggunaan Lahan } & Luas (Ha) & $\begin{array}{c}\% \\
\text { Wilayah }\end{array}$ \\
\hline 1 & Dermaga & 0,173 & 0,005 \\
\hline 2 & Fasilitas Umum & 51,11 & 1,349 \\
\hline 3 & Hutan & 3,907 & 0,103 \\
\hline 4 & Industri Dan Pergudangan & 127,378 & 3,362 \\
\hline 5 & Jalan Aspal & 63,115 & 1,666 \\
\hline 6 & Kebun & 55,316 & 1,460 \\
\hline 7 & Komplek Militer & 9,849 & 0,260 \\
\hline 8 & Lapangan Olahraga & 3,283 & 0,087 \\
\hline 9 & Makam & 29,541 & 0,780 \\
\hline 10 & Mangrove & 19,978 & 0,527 \\
\hline 11 & Perairan darat & 654,564 & 17,277 \\
\hline 12 & Perdagangan dan Jasa & 56,154 & 1,482 \\
\hline 13 & Perkantoran & 41,011 & 1,082 \\
\hline 14 & Permukiman & 1067,554 & 28,178 \\
\hline 15 & Persawahan & & 6,495 \\
\hline
\end{tabular}

${ }^{19}$ Neraca Penatagunaan Tanah Kota Pasuruan Tahun 2013, Kanwil BPN Provinsi Jawa Timur 


\begin{tabular}{|r|l|r|r|}
\hline 16 & Sawah Irigasi 2x Padi/Tahun & 1.242072 & 32,785 \\
\hline 17 & Sungai / Waduk & 18,626 & 0,492 \\
\hline 18 & Tambak & 23,042 & 0,608 \\
\hline 19 & Tanah Terbuka & 65,525 & 1,730 \\
\hline 20 & Tegalan & 10,303 & 0,272 \\
\hline \multicolumn{2}{|c|}{ Total } & $\mathbf{3 . 7 8 8 . 5 8}$ & $\mathbf{1 0 0 , 0 0}$ \\
\hline
\end{tabular}

\subsubsection{Penguasaan Tanah}

Gambaran penguasaan tanah di Kota Pasuruan tahun 2011 adalah sebagian besar wilayahnya merupakan tanah perorangan dan instansi pemerintah. Penguasaan tanah perorangan dengan luas 3255,8,2 Ha dengan luasan terbesar berada di Kecamatan Bugul Kidul $(1678,42 \mathrm{Ha})$. Sementara itu pada tanah instansi pemerintah $(3,6 \%)$ luasan terbesar berada di Kecamatan Purworejo (63,02 Ha). Sebaran penguasaan tanah di Kota Pasuruan dimana pola penguasaan tanah milik negara terletak pada bagian utara, tepatnya di pesisir Kota Pasuruan. Untuk tanah milik instansi pemerintah lebih banyak berada pada bagian tengah kota yaitu Kecamatan Purworejo dimana di Kecamatan Purworejo banyak terdapat perkantoran skala Kota. Tanah yang dikuasai oleh badan hukum lebih banyak terletak di sebelah barat dan utara Kota Pasuruan. Tanah di Kota Pasuruan didominasi oleh tanah milik perorangan sebesar $90,83 \%$ dari total luas wilayah Kota Pasuruan.

Tabel 12. Penguasaan Tanah Kota Pasuruan Tahun 2013

\begin{tabular}{|c|c|c|c|}
\hline No & $\begin{array}{c}\text { Gambaran Umum Penguasaan } \\
\text { Tanah }\end{array}$ & Luas (Ha) & $\%$ Wilayah \\
\hline 1 & Badan Hukum & 3,46 & 0,09 \\
\hline 2 & Hak Guna Bangunan & 127,38 & 3,36 \\
\hline 3 & Instansi Pemerintah & 135,80 & 3,58 \\
\hline 4 & Jalan & 6346 & 1,67 \\
\hline 5 & Kelompok Masyarakat & 0,83 & 0,02 \\
\hline 6 & Negara & 22,93 & 0,61 \\
\hline 7 & Perorangan & $3.255,80$ & 85,94 \\
\hline \multirow[t]{2}{*}{8} & Sungai & 178,91 & 4,72 \\
\hline & Total & $3.788,58$ & 100,00 \\
\hline
\end{tabular}

\subsection{Kabupaten Mojokerto}

Kabupaten Mojokerto adalah sebuah kabupaten di Provinsi Jawa Timur. Resmi didirikan pada tanggal 9 Mei 1293, kabupaten ini merupakan wilayah tertua ke-10 di Provinsi Jawa Timur dan merupakan salah satu wilayah yang masuk dalam kawasan metropolitan Surabaya, yaitu Gerbangkertosusila. Dahulu pusat pemerintahan masih berada di Kota Mojokerto, namun kini banyak gedung dan kantor pemerintahan yang dipindahkan ke Kecamatan Mojosari 
sebelah timur kota Mojokerto setelah Kota Mojokerto berdiri pada tanggal 20 Juni 1918. Sebelumnya Kabupaten Jombang juga merupakan bagian dari wilayah Kabupaten Mojokerto sebelum diberi kemandirian manjadi sebuah Kabupaten sendiri pada tahun $1910 .^{20}$

\subsubsection{Kondisi Geografis Wilayah}

Kabupaten Mojokerto Kabupaten Mojokerto secara astronomis terletak pada $111^{\circ} 20^{\prime} 13^{\prime \prime}$

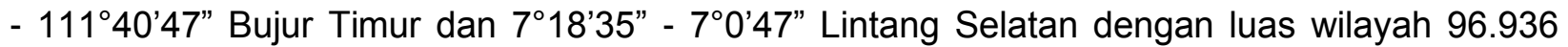
hektar. Adapun batas administrasi Kabupaten Mojokerto sebagai berikut :21

- Sebelah Utara $\quad$ : Kabupaten Lamongan dan Kabupaten Gresik

- Sebelah Timur : Kabupaten Sidoarjo dan Kabupaten Pasuruan

- Sebelah Selatan : Kabupaten Malang dan Kota Batu

- Sebelah Barat : Kabupaten Jombang

Kabupaten ini terbagi menjadi 18 kecamatan dan 304 desa/kelurahan, dimana 299 berstatus desa dan 5 berstatus kelurahan. Berikut perincian luas masing-masing kecamatan di wilayah Kabupaten Mojokerto.

Tabel 13. Luas Wilayah Kecamatan di Kabupaten Mojokerto Tahun 2016

\begin{tabular}{|r|l|r|r|}
\hline No. & \multicolumn{1}{|c|}{ Kecamatan } & \multicolumn{1}{c|}{ Luas (Ha) } & \% wilayah \\
\hline 1 & Bangsal & $2.471,83$ & 2,54 \\
\hline 2 & Dawarblandong & $8.034,89$ & 8,24 \\
\hline 3 & Dlanggu & $3.745,29$ & 3,84 \\
\hline 4 & Gedeg & $2.651,38$ & 2,72 \\
\hline 5 & Gondang & $11.318,29$ & 11,61 \\
\hline 6 & Jatirejo & $8.556,88$ & 8,78 \\
\hline 7 & Jetis & $6.016,25$ & 6,17 \\
\hline 8 & Kemlagi & $5.805,74$ & 5,96 \\
\hline 9 & Kutorejo & $4.584,22$ & 4,70 \\
\hline 10 & Mojoanyar & $2.482,67$ & 2,55 \\
\hline 11 & Mojosari & $2.891,31$ & 2,97 \\
\hline 12 & Ngoro & $6.928,84$ & 7,11 \\
\hline 13 & Pacet & $9.850,53$ & 10,11 \\
\hline 14 & Pungging & $4.558,80$ & 4,68 \\
\hline 15 & Puri & $3.785,79$ & 3,88 \\
\hline 16 & Sooko & $2.508,08$ & 2,57 \\
\hline 17 & Trawas & $6.612,11$ & 6,78 \\
\hline 18 & Trowulan & $4.662,09$ & 4,78 \\
\hline \multicolumn{2}{|c|}{ Total } & $97.465,00$ & 100 \\
\hline
\end{tabular}

Sumber : Kanwil BPN Propinsi Jawa Timur

\footnotetext{
${ }^{20}$ https://id.wikipedia.org/wiki/Kabupaten_Mojokerto

${ }^{21}$ Neraca Penatagunaan Tanah Kabupaten Mojokerto, 2016.
} 


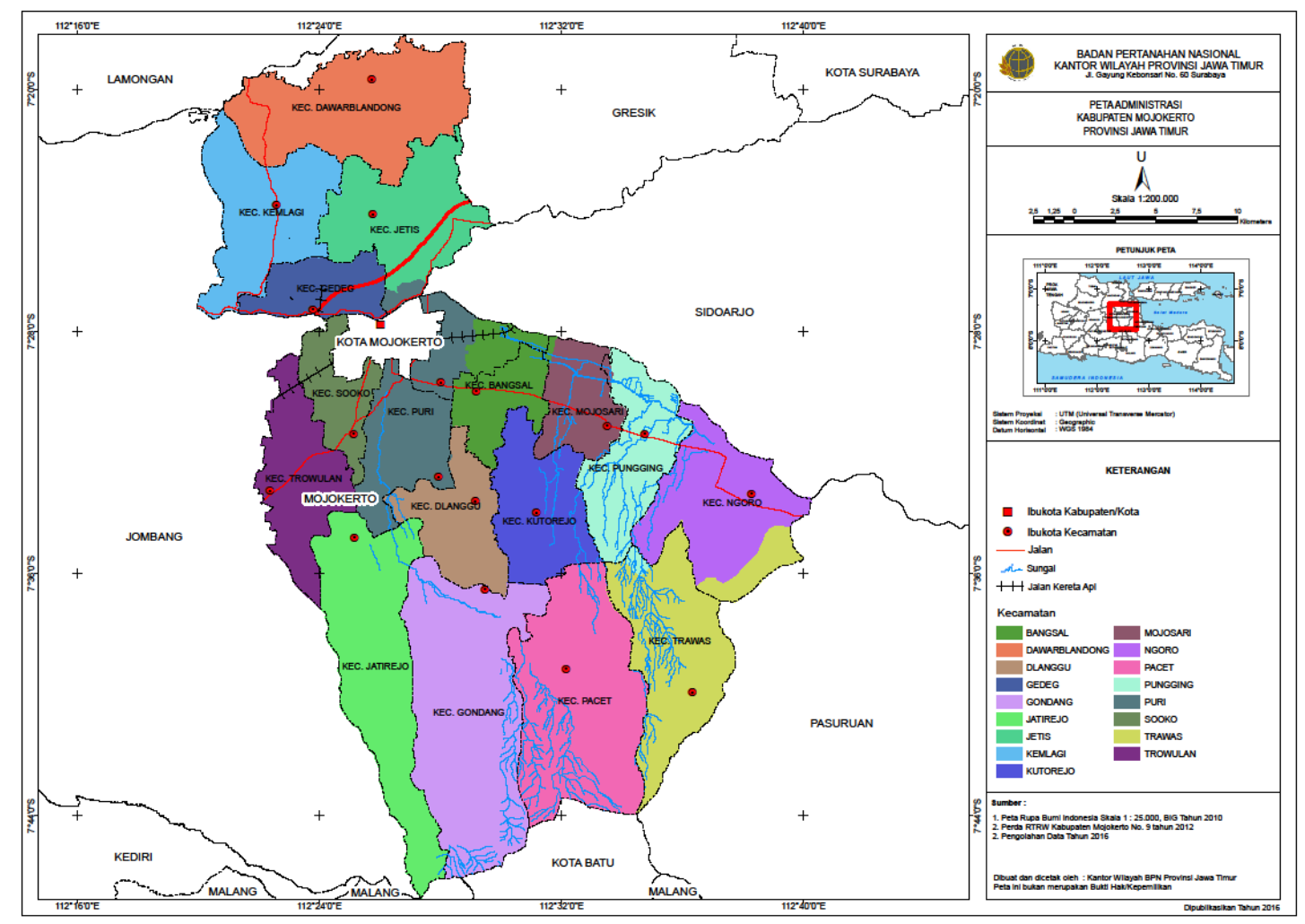

Sumber : Kanwil BPN Propinsi Jawa Timur

Gambar 7. Peta administrasi Kabupaten Mojokerto

\subsubsection{Kondisi Sosial Ekonomi Wilayah}

Berdasarkan data Badan Pusat Statistik Kabupaten Mojokerto Tahun 2015, jumlah penduduk Kabupaten Mojokerto adalah 1.174.603 jiwa. Kecamatan dengan jumlah penduduk terbesar adalah Kecamatan Jetis sebanyak 89.710 jiwa, sedangkan kecamatan dengan penduduk paling sedikit adalah Kecamatan Trawas dengan penduduk sejumlah 31.916 jiwa.

Hal ini ditunjang dengan peranan Kecamatan Jetis sebagai pusat pelayanan dalam hierarki pelayanan. Aktivitas perekonomian yang tinggi memicu mobilitas penduduk disamping pertumbuhan secara alami.

Sementara dalam hal lapangan usaha penunjang ekonomi, sektor Industri pengolahan merupakan penyumbang terbesar pada PDRB dengan menyumbang lebih dari $50 \%$. Sektor ini juga menjadi sektor yang paling banyak menyerap tenaga kerja. Pada tahun 2014 tercatat sebayak 168.365 orang penduduk dari usia produktif bekerja di sektor ini. ${ }^{22}$ Sektor Konstruksi dan Perdagangan Eceran berada di urutan selanjutnya dengan persentase masing-masing 10 $\%$. Sementara sektor pertanian menyumbang sebesar $9 \%$ dari total luas lahan untuk usaha pertanian $97.862 \mathrm{Ha}^{23}$

\footnotetext{
22 http://www.mojokertokab.go.id/thm/v1/?vi=data\&mode=1

${ }^{23}$ http://arsipweb.mojokertokab.go.id/index.php?mn=data_statistik\&vi=data_statistik\&id=3
} 


\subsubsection{Penggunaan Tanah}

Penggunaan tanah Kabupaten Mojokerto pada tahun 2016 didominasi oleh kelompok budidaya yaitu seluas $10.717,5 \mathrm{Ha}(97,38 \%)$, meliputi budidaya non pertanian seluas $6.959,5$ $\mathrm{Ha}(63,23 \%)$, dan budidaya pertanian sebesar $3.758 \mathrm{Ha}(34,14 \%)$. Sisanya adalah kelompok non budidaya seluas $288,9 \mathrm{Ha}(2,62 \%)$.

Penggunaan tanah yang paling luas di Kabupaten Mojokerto tahun 2016 masih berupa sawah irigasi $2 x$ padi/tahun seluas $43.021,56$ Ha (44,14\%), tersebar merata di seluruh kecamatan di Kabupaten Mojokerto. Sawah irigasi 2x padi/tahun terluas terdapat di Kecamatan Dawarblandong. Penggunaan tanah terluas kedua adalah hutan sejenis yaitu seluas $23.522,80$ $\mathrm{Ha}(24,13 \%)$. Penggunaan tanah terluas ketiga adalah Industri seluas $9.733,00 \mathrm{Ha}(9,99 \%)$.

Tabel 14. Penggunaan Tanah Kabupaten Mojokerto 2016

\begin{tabular}{|r|l|r|r|}
\hline No & \multicolumn{1}{|c|}{ Penggunaan Tanah } & Luas (Ha) & \multicolumn{1}{c|}{$\%$} \\
\hline & Budidaya Non Pertanian & $\mathbf{1 6 . 8 1 5 , 6 6}$ & $\mathbf{1 7 , 2 5}$ \\
\hline 1 & Perumahan Jarang & 102,01 & 0,10 \\
\hline 2 & Perumahan Padat & $1.438,91$ & 1,48 \\
\hline 3 & Industri & $9.733,00$ & 9,99 \\
\hline 4 & Kampung Jarang & 16,07 & 0,02 \\
\hline 5 & Kampung Padat & $5.136,19$ & 5,27 \\
\hline 6 & Emplasemen Tetap (TOL) & 4,32 & 0,00 \\
\hline 7 & Tanah Terbuka Sementara & 385,17 & 0,40 \\
\hline & Budidaya Pertanian & $\mathbf{5 6 . 5 4 4 , 1 2}$ & $\mathbf{5 8 , 0 1}$ \\
\hline 1 & Kebun Campuran & $1.314,07$ & 1,35 \\
\hline 2 & Kebun Sejenis & 187,60 & 0,19 \\
\hline 3 & Sawah Irigasi 2xpadi/th & $43.021,56$ & 44,14 \\
\hline 4 & Sawah Tadah Hujan & $7.577,40$ & $\mathbf{7 , 7 7}$ \\
\hline 5 & Tegalan/Ladang & $4.443,49$ & 4,56 \\
\hline & Non Budidaya & $\mathbf{2 4 . 1 0 5 , 2 2}$ & $\mathbf{2 4 , 7 3}$ \\
\hline 1 & Hutan Sejenis & $23.522,80$ & 24,13 \\
\hline 2 & Kuburan/Pemakaman Unmum & 15,113 & 0,02 \\
\hline 3 & Sungai/Danau/Situ/Telaga & 567,311 & 0,58 \\
\hline & Jumlah & $97.465,00$ & 100 \\
\hline
\end{tabular}

Sumber : Kanwil BPN Propinsi Jawa Timur

Penguasaan tanah secara umum di Kabupaten Mojokerto sebagaimana terdapat dalam Neraca Penatagunaan Tanah Kabupaten Mojokerto adalah merupakan tanah Hak UUPA dan Perorangan seluas $71.805,59 \mathrm{Ha}(73,67 \%)$, Tanah Negara untuk Kepentingan Umum seluas $117,12 \mathrm{Ha}(0,12 \%)$ dan Kelompok tanah yang lain adalah Penguasaan Tanah Skala Besar (PTSB). 
Tabel 15. Gambaran Umum Penguasaan Tanah Kabupaten Mojokerto

\begin{tabular}{|r|l|r|r|}
\hline No & \multicolumn{1}{|c|}{ Gambaran Umum Pengusaan Tanah } & Luas (Ha) & \multicolumn{1}{c|}{$\%$} \\
\hline 1 & Hutan & $23.536,07$ & 24,15 \\
\hline 2 & PTSB Industri & $1.438,91$ & 1,48 \\
\hline 3 & Sungai/Danau/Situ/Telaga & 567,31 & 0,58 \\
\hline 4 & Tanah Hak UUPA, dan Perorangan & $71.805,59$ & 73,67 \\
\hline 5 & Tanah Negara untuk Kepentingan Umum & $97.465,00$ & 100 \\
\hline & Total & & 0,12 \\
\hline
\end{tabular}

Sumber : Kanwil BPN Propinsi Jawa Timur

Tanah Hak UUPA dan Perorangan meliputi tanah milik perorangan, instansi pemerintah, dan tanah yang dilekati hak atas tanah lainnya sesuai UUPA, baik bersertifikat maupun tidak. Kemudian Tanah Negara untuk Kepentingan Umum adalah tanah yang dikuasai instansi pemerintah dan juga meliputi penggunaan tanah berupa makam dan emplasemen tetap (TOL). Sedangkan kelompok tanah yang lain berupa Penguasaan Tanah Skala Besar (PTSB) adalah tanah yang dikuasai oleh badan hukum dengan skala luas tanah yang besar. PTSB Industri di Kabupaten Mojokerto didominasi oleh tanah-tanah industri, kelompok PTSB ini mencapai luas $1.438,91 \mathrm{Ha}(1,48 \%)$.

\subsection{Kota Cirebon}

Kota Cirebon adalah salah satu kota yang berada di Provinsi Jawa Barat, Indonesia. Kota ini berada di pesisir utara Pulau Jawa atau yang dikenal dengan jalur pantura yang menghubungkan Jakarta-Cirebon-Semarang-Surabaya. Kota Cirebon terletak pada 10833 Bujur Timur dan 641 Lintang Selatan pada pantai Utara Pulau Jawa, bagian timur Jawa Barat, memanjang dari barat ke timur $\pm 11 \mathrm{Km}$ dengan ketinggian dari permukaan laut $\pm 5 \mathrm{M}$ (termasuk dataran rendah). Letaknya yang berada di wilayah pantai menjadikan Kota Cirebon memiliki wilayah dataran yang lebih luas dibandingkan dengan wilayah perbukitannya. Luas Kota Cirebon adalah $3.735,82$ hektar atau $\pm 37 \mathrm{~km} 2$ dengan dominasi penggunaan lahan untuk perumahan (32\%) dan tanah pertanian (38\%).

Cirebon dikenal dengan nama Kota Udang dan Kota Wali. Selain itu kota Cirebon disebut juga sebagai Caruban Nagari (penanda gunung Ceremai)dan Grage (Negeri Gede dalam bahasa jawa cirebon berarti kerajaan yang luas).Sebagai daerah pertemuan budaya Jawa dan Sunda sejak beberapa abad silam, masyarakat Cirebon biasa menggunakan dua bahasa, bahasa Sunda dan Jawa.

Nama Cirebon berasal dari kata Caruban, dalam Bahasa sunda yang berarti campuran (karena budaya Cirebon merupakan campuran dari budaya Sunda, Jawa, Tionghoa, dan unsur- 
unsur budaya Arab) atau bisa juga berasal dari kata Ci yang artinya air atau sungai dan Rebon yang artinya udang dalam Bahasa Sunda (karena udang merupakan salah satu hasil perikanan Kota Cirebon).

Kota Cirebon dalam Penataan Ruang Nasional menurut Peraturan Pemerintah Nomor 26 Tahun 2008 tentang Rencana Tata Ruang Wilayah Nasional (RTRWN) adalah sebagai Pusat Kegiatan Nasional (PKN) yang merupakan salah satu pengembangan kawasan metropolitan, serta merupakan bagian dari kawasan andalan yaitu Ciayumajakuning (CirebonIndramayu-Majalengka-Kuningan) dengan sektor unggulan pertanian, industri, perikanan, dan pertambangan.

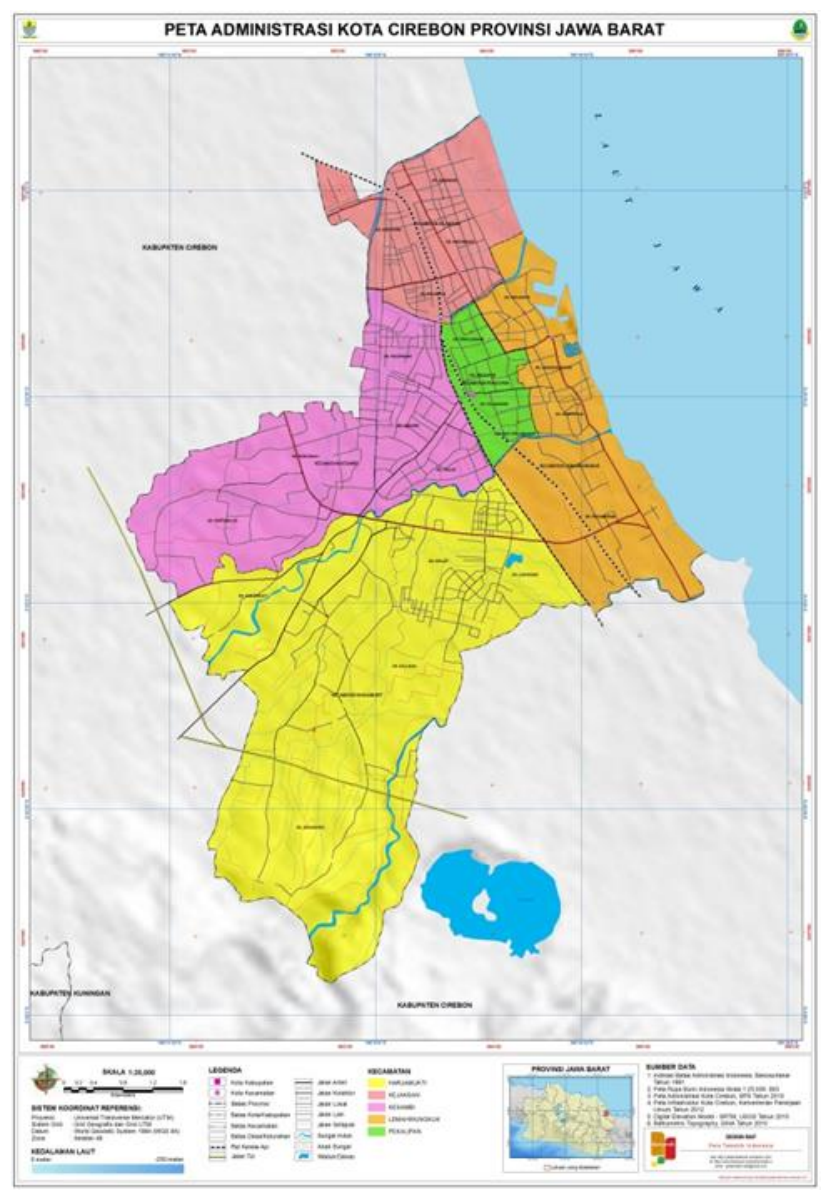

Sumber : https://petatematikindo.files.wordpress.com

Gambar 8. Peta Wilayah Kota Cirebon

\subsubsection{Kondisi Fisik Wilayah}

Secara topografis, sebagian besar wilayah Kota Cirebon merupakan dataran rendah dan sebagian kecil merupakan wilayah perbukitan yang berada di Wilayah Selatan kota. Kondisi wilayah kota yang sebagian besar berupa dataran rendah menjadi kendala tersendiri karena kecepatan aliran air hujan yang terbuang ke laut menjadi lambat dan sangat berpotensi 
menimbulkan genangan banjir di beberapa tempat. Oleh karena itu di beberapa titik dibangun stasiun pompa yang berfungsi mempercepat pembuangan air hujan ke laut.

Wilayah Kota Cirebon merupakan dataran rendah dengan ketinggian bervariasi antara 0 - 200 meter di atas permukaan laut. Peningkatan ketinggian mulai dari daerah pantai menuju ke arah Selatan dengan ketinggian maksimal 200 meter, yaitu di Kelurahan Argasunya, Kecamatan Harjamukti.

Berdasarkan letak geografisnya, wilayah Kabupaten Cirebon berada pada posisi $108^{\circ} 31,19^{\prime}-$ $108^{\circ} 35,36^{\prime}$ Bujur Timur dan $6^{\circ}$ 41,73' - 6 47,77' Lintang Selatan, yang dibatasi oleh:

Sebelah Utara : berbatasan dengan wilayah Kabupaten Cirebon dan Laut Jawa

Sebelah Barat : berbatasan dengan wilayah Kabupaten Cirebon

Sebelah Selatan : berbatasan dengan wilayah Kabupaten Cirebon

Sebelah Timur : berbatasan dengan wilayah Kabupaten Cirebon dan Laut Jawa

Kota Cirebon mempunyai luas $37,358 \mathrm{~km}^{2}$, dengan jumlah penduduk 307.494 jiwa, maka kepadatan penduduknya adalah 8.231 jiwa tiap $\mathrm{km}^{2}$. Pada Tabel 1. menunjukkan luas Kota Cirebon dibatasi oleh : wilayah Kota Cirebon untuk tiap-tiap kecamatan beserta dengan jumlah penduduknya pada tahun 2015.

Tabel 16. Luas Kecamatan dan Jumlah Penduduk Kota Cirebon 2015

\begin{tabular}{|r|l|r|r|}
\hline No & KECAMATAN & LUAS (Km2) & $\begin{array}{r}\text { JUMLAH } \\
\text { PENDUDUK } \\
\text { (jiwa) }\end{array}$ \\
\hline 1 & Harjamukti & 17,615 & 105.987 \\
\hline 2 & Lemahwungkuk & 6,507 & 54.788 \\
\hline 3 & Pekalipan & 1,561 & 30.013 \\
\hline 4 & Kesambi & 8,059 & 72.819 \\
\hline 5 & Kejaksan & 3,616 & 43.887 \\
\hline & Jumlah & $\mathbf{3 7 , 3 5 8}$ & $\mathbf{3 0 7 . 4 9 4}$ \\
\hline
\end{tabular}

Sumber : Kota Cirebon Dalam Angka 2016

Dari Tabel di atas Menunjukkan bahwa Kecamatan Harjamukti merupakan kecamatan dengan luas wilayah terbesar dan Kecamatan Pekalipan mempunyai luas wilayah terkecil. Begitu juga dengan jumlah penduduk, dimana Kecamatan Harjamukti yang tertinggi dan Kecamatan Pelakipan yang terendah. Setelah dilihat kepadatan penduduknya, yang terjadi sebaliknya, dimana kecamatan Harjamukti yang terendah yaitu $6.017 \mathrm{jiwa} / \mathrm{km}^{2}$, dan Kecamatan Pekalipan yang tertinggi yaitu $19.227 \mathrm{jiwa} / \mathrm{km}^{2}$.

Di Kota Cirebon terdapat empat sungai yang tersebar merata di seluruh wilayah yaitu Sungai Kedung Pane, Sungai Sukalila, Sungai Kesunean (Kriyan) dan Sungai Kalijaga. Sungai berfungsi sebagai batas wilayah antara Kabupaten Cirebon dan sebagai saluran pembuangan air. Sungai-sungai tersebut yang membawa material-material yang berasal dari hulu sampai ke muara, kemudian membentuk sedimentasi di sepanjang pantai. Kota Cirebon memiliki karakter sebagai kota pantai yang ditandai oleh pendangkalan yang cukup tinggi di daerah pantai sehingga menyebabkan terjadinya tanah-tanah timbul yang mempengaruhi luas wilayah administrasi kota. 


\subsubsection{Kondisi Sosial Ekonomi Wilayah}

Semakin bertambahnya jumlah penduduk dan kebutuhan akan aktivitas menyebabkan perubahan penggunaan lahan sulit di kontrol khususnya daerah perkotaan, untuk Kota Cirebon perubahan penggunaan lahan banyak terjadi dari lahan pertanian menjadi lahan non pertanian. Dari beberapa kejadian perubahan penggunaan lahan, terdapat 3 desa di Kecamatan Harjamukti dan 2 desa di Kecamatan Kesambi yang mengalami perubahan lahan pertanian sawah menjadi lahan non pertanian. Ditinjau dari penggunaan lahannya, sebagian besar lahan di Kota Cirebon digunakan untuk lahan non pertanian yang mencapai 95\% dari total lahan. Penggunaan lahan untuk pertanian hanya mencapai 5\%, terdiri lahan pertanian sawah $3 \%$ dan lahan pertanian non sawah $2 \%$.

Pada tahun 2014, leading sector perekonomian Kota Cirebon masih sama dengan tahun sebelumnya yaitu perdagangan. Nilai PDRB Atas Dasar Harga Berlaku pada tahun 2014 sebesar Rp 15,06 trilyun. Sedangkan nilai PDRB Atas Dasar Harga Konstan 2010 pada tahun 2014 sebesar Rp. 12,54 trilyun. Sektor perdagangan dan jasa merupakan sektor andalan bagi perekonomian Kota Cirebon. Majunya kedua sektor ini dikarenakan letak geografis Kota Cirebon yang strategis, sehingga menjadi pusat perdagangan bagi Wilayah III Cirebon yang meliputi Kabupaten Kuningan, Kabupaten Cirebon, Kabupaten Majalengka dan Kabupaten Indramayu, dan juga merupakan kota lintasan yang menghubungkan Jawa Barat dan Jawa Tengah. Kondisi tersebut memacu perkembangan perdagangan, jasa perhotelan dan pariswisata di Kota Cirebon.

\subsubsection{Penggunaan Tanah}

Pola penggunaan tanah Tahun 2015 tidak berubah dari penggunaan tanah tahun 2009, namun terjadi perubahan jumlah luas pada masing penggunaan tanah. Hal ini akibat meningkatnya aktivitas masyarakat dan peningkatan jumlah penduduk akibat dari urbanisasi yang mengakibatkan meningkatnya kebutuhan tanah untuk permukiman dan kegiatan lainnya. Kondisi penggunaan tanah Tahun 2015, perumahan tidak teratur yang paling dominan yaitu seluas 1.227,977 Ha (32,08\%). Dibanding data penggunaan tanah tahun 2009 perumahan tidak teratur mengalami penambahan sebesar 9,12 ha.

Tabel 17. Penggunaan Tanah Kota Cirebon Tahun 2015

\begin{tabular}{|l|l|l|l|}
\hline No. & Jenis Penggunaan Tanah & Hektar & $\%$ \\
\hline 1 & Akomodasi dan Rekreasi & 29,139 & 0,76 \\
\hline 2 & Bandar Udara & 23,593 & 0,62 \\
\hline 3 & Industri Non Pertanian & 62,727 & 1,64 \\
\hline 4 & Industri Pengolahan Pertanian & 3,067 & 0,08 \\
\hline 5 & Instalasi Listrik & 12,876 & 0,34 \\
\hline 6 & Jalan Tol & 11,458 & 0,30 \\
\hline 7 & Jalan Utama & 61,918 & 1,62 \\
\hline 8 & Jasa Kesehatan & 15,637 & 0,41 \\
\hline 9 & Jasa Pelayanan Umum & 0,958 & 0,03 \\
\hline 10 & Jasa Pemerintahan & 19,238 & 0,50 \\
\hline 11 & Jasa Pendidikan & 72,480 & 1,89 \\
\hline 12 & Jasa Peribadatan & 4,150 & 0,11 \\
\hline 13 & Kantor/Bangunan Militer & 8,569 & 0,22 \\
\hline
\end{tabular}




\begin{tabular}{|l|l|l|l|}
\hline 14 & Kebun Campuran & 565,170 & 14,77 \\
\hline 15 & Kolam/Empang & 8,335 & 0,22 \\
\hline 16 & Komplek Keraton & 14,170 & 0,37 \\
\hline 17 & Lapangan/Gedung Olahraga & 15,840 & 0,41 \\
\hline 18 & Lembaga Keuangan Non Bank & 0,872 & 0,02 \\
\hline 19 & Lembaga Keuangan/Bank & 11,160 & 0,29 \\
\hline 20 & Makam & 44,250 & 1,16 \\
\hline 21 & Mangrove & 15,603 & 0,41 \\
\hline 22 & Padang Rumput & 30,408 & 0,79 \\
\hline 23 & Pasar & 6,974 & 0,18 \\
\hline 24 & Pelabuhan Laut & 55,530 & 1,45 \\
\hline 25 & Perbengkelan & 1,549 & 0,04 \\
\hline 26 & Perdagangan Umum & 162,442 & 4,24 \\
\hline 27 & Pergudangan & 70,572 & 1,84 \\
\hline 28 & Perkantoran & 19,972 & 0,52 \\
\hline 29 & Perumahan Teratur & 476,840 & 12,46 \\
\hline 30 & Perumahan Tidak Teratur & $1.227,977$ & 32,08 \\
\hline 31 & Peternakan & 0,791 & 0,02 \\
\hline 32 & Rumah Dinas Bupati & 1,750 & 0,05 \\
\hline 33 & Sawah Irigasi 2x Padi/Tahun & 12,629 & 0,33 \\
\hline 34 & Sawah Tadah Hujan & 269,778 & 7,05 \\
\hline 35 & Semak Belukar & 11,356 & 0,30 \\
\hline 36 & Situ/Danau/Waduk & 3,243 & 0,08 \\
\hline 37 & Stasiun KA & 1,680 & 0,04 \\
\hline 38 & Sungai & 40,606 & 1,06 \\
\hline 39 & Taman & 47,156 & 1,23 \\
\hline 40 & Tambak & 95,335 & 2,49 \\
\hline 41 & Tanah Kosong & 152,422 & 3,98 \\
\hline 42 & Tegalan/Ladang & 133,908 & 3,50 \\
\hline 43 & Terminal Umum/Bus & 3,465 & 0,09 \\
\hline Jumlah & $\mathbf{3 . 8 2 7 , 5 9 4}$ & $\mathbf{1 0 0 , 0 0}$ \\
\hline & Ket:Luasyangdigunak bedasanan & \\
\hline
\end{tabular}

Ket : Luas yang digunakan berdasarkan hasil digitas peta

Sumber:Olahan Peta Penggunaan Tanah Kota Cirebon Tahun 2015

\subsubsection{Penguasaan Tanah}

Berdasarkan data pada tabel di bawah ini, dapat diketahui bahwa gambaran umum penguasaan tanah di Kota Cirebon terluas adalah tanah hak UUPA dan perorangan seluas $3.345,220 \mathrm{Ha}$ atau $87,40 \%$ dari luas wilayah, terluas kedua selanjutnya adalah tanah negara dikuasai seluas $129,003 \mathrm{Ha}$ atau 3,37\%, sedangkan terkecil adalah tanah keraton yaitu seluas 14,170 Ha.

Tabel 18 Penguasaan Tanah Kota Cirebon Tahun 2015

\begin{tabular}{|c|l|l|l|}
\hline No & Jenis Penggunaan Tanah & Hektar & $\%$ \\
\hline 1 & Jalan Tol & 11,458 & 0,30 \\
\hline 2 & Jalan Utama & 61,918 & 1,62 \\
\hline 3 & PTSB Industri & 65,794 & 1,72 \\
\hline 4 & PTSB Perumahan & 107,888 & 2,82 \\
\hline 5 & Situ/Danau/Waduk & 3,243 & 0,08 \\
\hline 6 & Sungai & 40,606 & 1,06 \\
\hline 7 & Tanah Hak UUPA \& Perorangan & $3.345,220$ & 87,40 \\
\hline
\end{tabular}




\begin{tabular}{|c|l|l|l|}
\hline 8 & Tanah Keraton & 14,170 & 0,37 \\
\hline 9 & Tanah Komunal & 48,294 & 1,26 \\
\hline 10 & Tanah Negara Dikuasai & 129,003 & 3,37 \\
\hline \multicolumn{2}{|l|}{ Jumlah } & $\mathbf{3 . 8 2 7 , 5 9 4}$ & $\mathbf{1 0 0 , 0 0}$ \\
\hline
\end{tabular}

Sumber : Neraca Penatagunaan Tanah Kota Cirebon

\subsection{Kabupaten Cirebon}

Kabupaten Cirebon merupakan salah satu kabupaten di Provinsi Jawa Barat yang terletak di sebelah timur laut. Kabupaten Cirebon berada di perbatasan dengan Provinsi Jawa Tengah, yaitu Kabupaten Brebes.

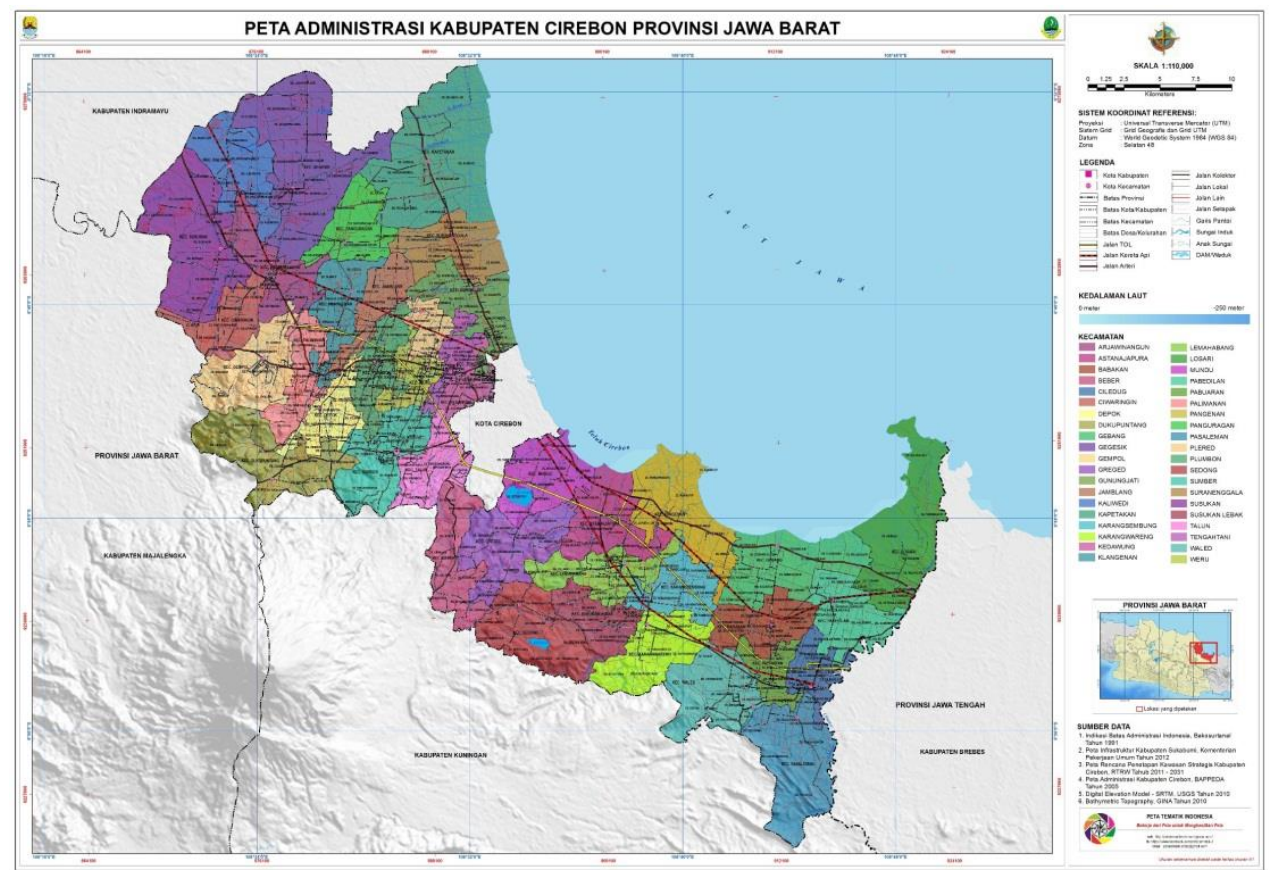

Sumber : https://petatematikindo.files.wordpress.com

Gambar 9. Peta Administrasi Kabupaten Cirebon

Berdasarkan letak geografisnya, wilayah Kabupaten Cirebon berada pada posisi $108^{\circ} 40^{\prime}-$ $108^{\circ} 48^{\prime}$ Bujur Timur dan 6 $6^{\circ} 30^{\prime}-7^{\circ} 00^{\prime}$ Lintang Selatan, yang dibatasi oleh:

Sebelah Utara : berbatasan dengan wilayah Kabupaten Indramayu, Kota Cirebon dan Laut Jawa

Sebelah Barat : berbatasan dengan wilayah Kabupaten Majalengka, Kabupaten Kuningan, dan Kabupaten Indramayu.

Sebelah Selatan: berbatasan dengan wilayah Kabupaten Kuningan dan Kabupaten Majalengka.

Sebelah Timur : berbatasan dengan Kabupaten Brebes Provinsi Jawa Tengah.

Kabupaten Cirebon mempunyai luas 990,36 km², dengan jumlah penduduk 2.183 .695 jiwa, maka kepadatan penduduknya adalah 2.205 jiwa tiap $\mathrm{km}^{2}$. Pada tabel berikut menunjukkan 
luas wilayah Kabupaten Cirebon untuk tiap-tiap kecamatan beserta dengan jumlah penduduknya pada tahun 2015.

Tabel 19. Luas Kecamatan dan Jumlah Penduduk Kabupaten Cirebon 2015

\begin{tabular}{|c|c|c|c|}
\hline No & KECAMATAN & $\begin{array}{l}\text { LUAS } \\
\text { (Km2) }\end{array}$ & $\begin{array}{c}\text { JUMLAH } \\
\text { PENDUDUK } \\
\text { (jiwa) }\end{array}$ \\
\hline 1 & Arjawinangun & 24,11 & 58.725 \\
\hline 2 & Astanajapura & 25,47 & 72.098 \\
\hline 3 & Babakan & 21,93 & 72.461 \\
\hline 4 & Beber & 32,25 & 41.559 \\
\hline 5 & Ciledug & 13,25 & 45.508 \\
\hline 6 & Ciwaringin & 17,79 & 34.561 \\
\hline 7 & Depok & 15,55 & 63.810 \\
\hline 8 & Dukupuntang & 26,40 & 62.162 \\
\hline 9 & Gebang & 31,68 & 65.143 \\
\hline 10 & Gegesik & 60,38 & 74.269 \\
\hline 11 & Gempol & 30,73 & 46.795 \\
\hline 12 & Greged & 29,92 & 59.172 \\
\hline 13 & Gunung Jati & 20,55 & 76.062 \\
\hline 14 & Jamblang & 17,76 & 39.046 \\
\hline 15 & Kaliwedi & 27,82 & 42.394 \\
\hline 16 & Kapetakan & 60,20 & 57.882 \\
\hline 17 & Karangsembung & 15,14 & 37.658 \\
\hline 18 & Karangwareng & 23,12 & 30.849 \\
\hline 19 & Kedawung & 9,58 & 56.462 \\
\hline 20 & Klangenan & 20,57 & 47.937 \\
\hline
\end{tabular}

\begin{tabular}{|r|l|r|c|}
\hline No & KECAMATAN & $\begin{array}{r}\text { LUAS } \\
\text { (Km2) }\end{array}$ & $\begin{array}{c}\text { JUMLAH } \\
\text { PENDUDUK } \\
\text { (jiwa) }\end{array}$ \\
\hline 21 & Lemahabang & 21,49 & 55.046 \\
\hline 22 & Losari & 39,07 & 60.687 \\
\hline 23 & Mundu & 25,58 & 72.420 \\
\hline 24 & Pabedilan & 24,08 & 61.214 \\
\hline 25 & Pabuaran & 8,95 & 35.919 \\
\hline 26 & Palimanan & 17,18 & 62.282 \\
\hline 27 & Pangenan & 30,54 & 46.054 \\
\hline 28 & Panguragan & 20,31 & 47.033 \\
\hline 29 & Pasaleman & 32,11 & 31.501 \\
\hline 30 & Plered & 11,34 & 51.503 \\
\hline 31 & Plumbon & 18,19 & 69.507 \\
\hline 32 & Sedong & 31,02 & 44.626 \\
\hline 33 & Sumber & 25,65 & 88.255 \\
\hline 34 & Suranenggala & 22,98 & 44.271 \\
\hline 35 & Susukan & 50,10 & 69.153 \\
\hline 36 & Susukan Lebak & 18,74 & 41.719 \\
\hline 37 & Talun & 21,21 & 69.409 \\
\hline 38 & Tengah Tani & 8,97 & 39.021 \\
\hline 39 & Waled & 28,46 & 53.357 \\
\hline 40 & Weru & 9,19 & 56.165 \\
\hline
\end{tabular}

Sumber : Kabupaten Cirebon Dalam Angka 2016

Persebaran penduduk Kabupaten Cirebon per Kecamatan hingga pada Tahun 2015 masih menunjukkan kondisi kurang merata. Penduduk terbesar terdapat di Kecamatan Sumber yaitu sebanyak 88.255 jiwa dan yang terkecil adalah Kecamatan Karangwareng dengan jumlah penduduk hanya 30.849 jiwa. Kepadatan penduduk di masing-masing Kecamatan juga menunjukkan ketidakmerataan. Hal ini disebabkan kondisi dan potensi masing-masing wilayah kecamatan yang tidak sama, makin padatnya penduduk cenderung di pusat.

\subsubsection{Kondisi Fisik Wilayah}

Kondisi Topografi Kabupaten Cirebon berada pada ketinggian $0-300 \mathrm{~m}$ dpl. Wilayah dataran rendah yang terletak disepanjang pantai utara Jawa Barat memiliki ketinggian antara 0 - $25 \mathrm{~m}$ di atas permukaan air laut, yaitu Kecamatan Gunungjati, Suranenggala, Kapetakan, Mundu, Pangenan, Losari, Astanajapura dan Pabedilan. Wilayah yang memiliki ketinggian antara 25 - 100 mdpl berada dibagian tengah ke selatan, dan yang terletak pada ketinggian 100 
- $300 \mathrm{mdpl}$ ada di bagian selatan sedangkan yang memiliki ketinggian $300 \mathrm{~m}$ dpl terdapat disebagian wilayah Lemah Abang, Beber, Gegesik, Sedong, Dukupuntang dan Palimanan. Daerah bagian selatan di Kabupaten Cirebon merupakan daerah perbukitan.

Sedangkan berdasarkan kemiringannya wilayah Kabupaten Cirebon dikelompokkan menjadi enam kelompok, yaitu :

1. Daerah datar. Daerah ini memiliki kemiringan tanah antara $0 \%-3 \%$ dengan luas $77.670 \mathrm{Ha}$ atau $78,43 \%$ dari luas wilayah kabupaten.

2. Daerah landai I. Daerah ini memiliki kemiringan antara 3\% - 8\% dengan luas 5.500 $\mathrm{Ha}$ atau $5,55 \%$ dari luas wilayah kabupaten.

3. Daerah Landai II. Daerah ini memiliki kemiringan antara $8 \%-15 \%$ dengan luas $4.000 \mathrm{Ha}$ atau $4,04 \%$ dari luas wilayah kabupaten.

4. Daerah Miring I. Daerah ini memiliki kemiringan antara $15 \%-25 \%$ dengan luas $5.800 \mathrm{Ha}$ atau $5,86 \%$ dari luas wilayah kabupaten.

5. Daerah Miring II. Daerah ini memiliki kemiringan antara $25 \%-40 \%$ dengan luas $4.200 \mathrm{Ha}$ atau $4,24 \%$ dari luas wilayah kabupaten.

6. Daerah Terjal. Daerah ini memiliki kemiringan diatas $40 \%$ dengan luas $1.866 \mathrm{Ha}$ atau $1,88 \%$ dari luas wilayah kabupaten.

Sumber-sumber air yang ada di Kabupaten Cirebon berasal dari air permukaan dan air bawah tanah. Sumber air permukaan berasal dari beberapa sungai besar seperti : Sungai Cisanggarung, Sungai Ciwaringin, Sungai Cimanis, Sungai Cipager, Sungai Kumpul Kuista dan Sungai Jamblang. Selain itu terdapat sungai-sungai kecil yang merupakan anak sungai dari sungai-sungai besar yang berhulu di bagian Selatan. Sungai-sungai besar yang ada membentuk Daerah Aliran Sungai (DAS) yaitu DAS Cisanggarung dan DAS Cimanuk Hilir.

\subsubsection{Kondisi Sosial Ekonomi Wilayah}

Kota Kecamatan dan daerah perkotaan, dimana banyak terdapat kegiatan-kegiatan ekonomi masyarakat di berbagai bidang usaha yang dapat memberikan lapangan pekerjaan seperti perdagangan, industri, pengangkutan, pertanian, pertambangan, pemerintahan, jasajasa dan lain-lain, perkembangan jumlah pencari kerja di Kota Cirebon pada tahun 2015 sebanyak 25.604 orang dengan tingkat pendidikan terbanyak lulusan SLTA sederjat sebanyak 13.717 orang.

Salah satu sumber devisa bagi Kabupaten Cirebon adalah sektor perikanan. Perikanan disini meliputi perikanan darat (kolam dan waduk), perikanan tambak, dan perikanan Laut. Selain potensi perikanan, kawasan pantai utara Kabupaten Cirebon, juga memiliki potensi penggaraman seluas $\pm 7.500 \mathrm{Ha}$ dengan rata-rata produksi $\pm 67.740 \mathrm{Ton} /$ tahun yang cukup besar kontribusinya dalam memenuhi kebutuhan garam, baik ditingkat lokal maupun nasional.

Sektor Pertanian masih merupakan sector andalan bagi Kabupaten Cirebon, terlihat dari kontribusinya terhadap PDRB yang hamper $30 \%$. Tanaman pangan yang dimaksud meliputi tanaman bahan makanan (padi-padian, jagung, umbi-umbian dan kacang-kacangan), sayuran dan buah-buahan. Produksi padi sawah kabupaten Cirebon pada tahun 2013 mengalami peningkatan (618.891 ton) dibandingkan produksi pada tahun 2012 (489.002 ton). Produksi padi Kecamatan Gegesik mampu menghasilkan 71.522 Ton padi sawah dengan luas panen sebesar $10.446 \mathrm{Ha}$. Pada tahun 2013, produksi padi gabah kering giling sebesar 620.788 Ton. 


\subsubsection{Penggunaan Tanah}

Kondisi penggunaan tanah Tahun 2016, dimana yang paling dominan yaitu sawah irigasi 2x padi/tahun seluas 47.208,330 Ha (43,99\%). Dibanding data penggunaan tanah tahun 2010 sawah irigasi $2 x$ padi/tahun mengalami penurunan sebesar 248,86 ha.

Tabel 20. Penggunaan Tanah Kabupaten Cirebon Tahun 2016

\begin{tabular}{|c|c|c|c|}
\hline Jenis Penggunaan Tanah & Jumlah & \multicolumn{2}{|l|}{$\begin{array}{l}\% \text { Luas } \\
\text { Wilayah }\end{array}$} \\
\hline Bendungan & 0,792 & \multicolumn{2}{|l|}{0,00} \\
\hline Emplasemen Tetap & 44,469 & \multicolumn{2}{|l|}{0,04} \\
\hline Hutan Belukar & $3.502,471$ & \multicolumn{2}{|l|}{3,26} \\
\hline Hutan Mangrove & 46,464 & \multicolumn{2}{|l|}{0,04} \\
\hline Hutan Sejenis & $3.188,454$ & \multicolumn{2}{|l|}{2,97} \\
\hline Industri Aneka Bahan Bangunan & 18,802 & \multicolumn{2}{|l|}{0,02} \\
\hline Industri Aneka Kimia dan Serat & 4,688 & \multicolumn{2}{|l|}{0,00} \\
\hline Industri Aneka Pangan & 43,597 & 0,04 & \\
\hline Industri Aneka Sandang & 12,942 & 0,01 & \\
\hline Industri Kecil & 21,318 & 0,02 & \\
\hline Industri Non Pertanian & 408,399 & 0,38 & \\
\hline Instalasi Listrik & 54,030 & 0,05 & \\
\hline Jalan Pantura & 119,659 & 0,11 & \\
\hline Jalan Tol & 252,350 & 0,24 & \\
\hline Jasa Kesehatan & 25,594 & 0,02 & \\
\hline Jasa Pemerintahan & 104,310 & 0,10 & \\
\hline Jasa Pendidikan & 181,872 & 0,17 & \\
\hline Jasa Peribadatan & 13,548 & 0,01 & \\
\hline Kampung Jarang & $1.408,515$ & 1,31 & \\
\hline Kampung Padat & $14.882,295$ & 13,87 & \\
\hline Kebun Campuran & $10.385,702$ & 9,68 & \\
\hline Kebun Sejenis & 311,642 & 0,29 & \\
\hline Kolam Air Tawar & 38,325 & 0,04 & \\
\hline Komplek Olah Raga & 17,320 & 0,02 & \\
\hline Lapangan Golf & 66,731 & 0,06 & \\
\hline Lapangan Olah Raga & 76,290 & 0,07 & \\
\hline Makam Khusus & 2,345 & 0,00 & \\
\hline Padang Rumput & 43,270 & 0,04 & \\
\hline Pasar & 11,870 & 0,01 & \\
\hline Pasir Pantai & 476,420 & 0,44 & \\
\hline Pemakaman Umum & 280,128 & & 0,26 \\
\hline Penggaraman & $1.646,784$ & & 1,53 \\
\hline Perdagangan Umum & 129,817 & & 0,12 \\
\hline Pergudangan & 204,332 & & 0,19 \\
\hline Pertambangan Terbuka & 346,804 & & 0,32 \\
\hline Perumahan Jarang & 382,897 & & 0,36 \\
\hline Perumahan Padat & 474,244 & & 0,44 \\
\hline Peternakan & 29,276 & & 0,03 \\
\hline Rawa & 7,767 & & 0,01 \\
\hline Sawah Irigasi 2x Padi/Tahun & $47.208,330$ & & 43,99 \\
\hline $\begin{array}{l}\text { Sawah Irigasi 2x Padi/Tahun + } \\
\text { Palawija }\end{array}$ & $4.345,597$ & & 4,05 \\
\hline Sawah Tadah Hujan & $3.342,856$ & & 3,11 \\
\hline Semak & 648,199 & & 0,60 \\
\hline
\end{tabular}




\begin{tabular}{|l|l|l|}
\hline Sungai/Danau/Situ/Telaga & $1.267,596$ & 1,18 \\
\hline Taman & 20,371 & 0,02 \\
\hline Tambak & $7.110,393$ & 6,63 \\
\hline Tanah Terbuka Sementara & 145,319 & 0,14 \\
\hline Tegalan/Ladang & $3.965,512$ & 3,69 \\
\hline Terminal & 2,717 & 0,00 \\
\hline JUMLAH & $\mathbf{1 0 7 . 3 2 3 , 4 2 1}$ & $\mathbf{1 0 0 , 0 0}$ \\
\hline
\end{tabular}

Ket : Luas yang digunakan berdasarkan hasil digitas peta

Sumber : Olahan Peta Penggunaan Tanah Kabupaten Cirebon Tahun 2016

\subsubsection{Penguasaan Tanah}

Berdasarkan data pada tabel 21, dapat diketahui bahwa gambaran umum penguasaan tanah di Kabupaten Cirebon terluas adalah tanah Hak UUPA dan Perorangan seluas $97.537,691 \mathrm{Ha}$ atau $90,88 \%$ dari luas wilayah, terluas selanjutnya adalah kawasan kehutanan seluas 5.326,006 $\mathrm{Ha}$ atau 4,96\%, sedangkan terkecil adalah penguasaan tanah skala besar (PTSB) perikanan seluas 226,381 $\mathrm{Ha}$.

Tabel 21. Penguasaan Tanah Kabupaten Cirebon Tahun 2016

$\begin{array}{lll}\text { Jenis Penguasaan Tanah } & \text { Jumlah } & \text { \% Luas Wilayah } \\ \text { Kawasan Kehutanan } & 5.326,006 & 4,96 \\ \text { PTSB Industri } & 506,892 & 0,47 \\ \text { PTSB Perikanan } & 226,381 & 0,21 \\ \text { PTSB Perumahan } & 857,141 & 0,80 \\ \text { Sungai/Danau/Situ/Telaga } & 1.267,596 & 1,18 \\ \text { Tanah Hak UUPA \& Perorangan } & 97.537,691 & 90,88 \\ \text { Tanah Komunal } & 372,099 & 0,35 \\ \text { Tanah Negara Lainnya } & 476,420 & 0,44 \\ \text { Tanah Negara Untuk Kepentingan Umum } & \mathbf{7 5 3 , 1 9 4} & 0,70 \\ \text { Jumlah } & \mathbf{1 0 7 . 3 2 3 , 4 2 1} & \mathbf{1 0 0 , 0 0}\end{array}$

Ket : Luas yang digunakan berdasarkan hasil digitas peta

Sumber : Olahan Peta GUPT Kabupaten Cirebon Tahun 2016

\subsection{Kabupaten Indramayu}

Kabupaten Indramayu terletak di pesisir utara Jawa Barat yang memiliki panjang garis pantai $147 \mathrm{Km}$. Wilayah Kabupaten Indramayu yang berbatasan langsung dengan laut terdiri dari 11 kecamatan dengan 36 desa.

Secara geografis Kabupaten Indramayu terletak membujur pada posisi $107^{0} 52^{\prime}-108^{0}$ 36' Bujur Timur dan $6^{\circ} 15^{\prime}-6^{\circ} 40^{\prime}$ Lintang Selatan. Batas-batas wilayah Kabupaten Indramayu adalah sebagai berikut :

Sebelah Utara : berbatasan dengan Laut Jawa

Sebelah Barat : berbatasan dengan wilayah Kabupaten Subang.

Sebelah Selatan : berbatasan dengan Kabupaten Majalengka, Kabupaten Sumedang dan Kabupaten Cirebon.

Sebelah Timur : berbatasan dengan Kabupaten Cirebon dan Laut Jawa 

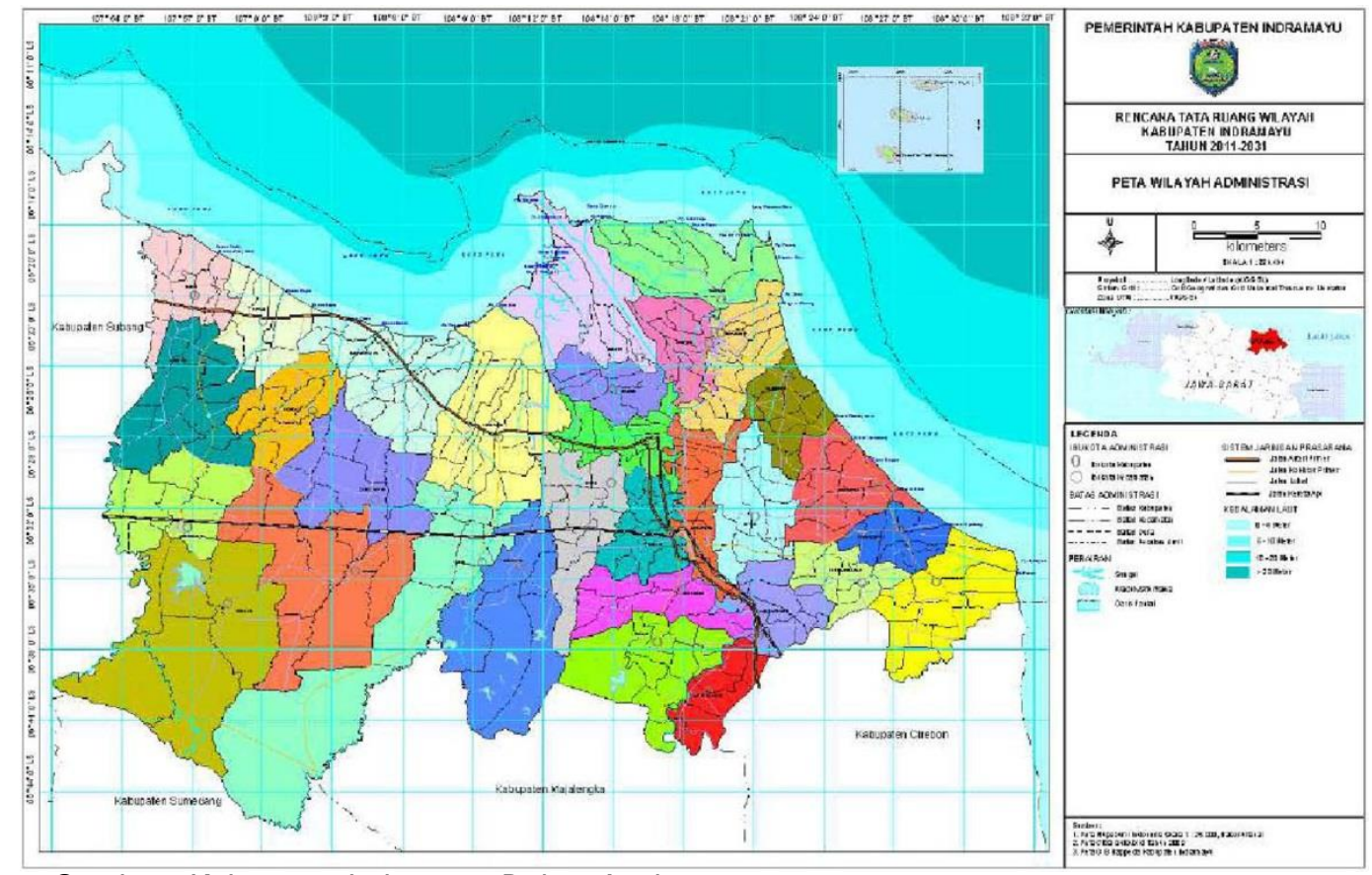

Sumber : Kabupaten Indramayu Dalam Angka 2017

Gambar 10. Peta Administrasi Kabupaten Indramayu

Kabupaten Indramayu mempunyai luas $2.099,42 \mathrm{~km}^{2}$, dengan jumlah penduduk 1.728.049 jiwa, maka kepadatan penduduknya adalah 823 jiwa tiap $\mathrm{km}^{2}$. Pada tabel berikut menunjukkan luas wilayah Kabupaten Indramayu untuk tiap-tiap kecamatan beserta dengan jumlah penduduknya pada tahun 2016.

Tabel 22. Luas Kecamatan dan Jumlah Penduduk Kabupaten Indramayu 2016

\begin{tabular}{|c|l|r|r|}
\hline No & KECAMATAN & $\begin{array}{r}\text { LUAS } \\
\text { (Km }^{2} \text { ) }\end{array}$ & $\begin{array}{c}\text { JUMLAH } \\
\text { PENDUDUK } \\
\text { (jiwa) }\end{array}$ \\
\hline 1 & Haurgeulis & 64,697 & 91.478 \\
\hline 2 & Gantar & 172,687 & 62.250 \\
\hline 3 & Kroya & 135,64 & 63.718 \\
\hline 4 & Gabuswetan & 79,115 & 55.492 \\
\hline 5 & Cikedung & 112,886 & 39.535 \\
\hline 6 & Terisi & 178,572 & 54.450 \\
\hline 7 & Lelea & 60,95 & 48.485 \\
\hline 8 & Bangodua & 47,307 & 27.784 \\
\hline 9 & Tukdana & 73,808 & 51.435 \\
\hline 10 & Widasari & 40,486 & 34.375 \\
\hline 11 & Kertasemaya & 39,458 & 61.474 \\
\hline 12 & Sukagumiwang & 33,214 & 37.818 \\
\hline
\end{tabular}

\begin{tabular}{|r|l|r|r|}
\hline No & KECAMATAN & \multicolumn{1}{c|}{$\begin{array}{c}\text { LUAS } \\
\text { (Km }^{2} \text { ) }\end{array}$} & $\begin{array}{c}\text { JUMLAH } \\
\text { PENDUDUK } \\
\text { (jiwa) }\end{array}$ \\
\hline 17 & Sliyeg & 54,857 & 59.525 \\
\hline 18 & Jatibarang & 43,022 & 70.943 \\
\hline 19 & Balongan & 35,085 & 38.890 \\
\hline 20 & Indramayu & 54,92 & 111.626 \\
\hline 21 & Sindang & 36,834 & 50.844 \\
\hline 22 & Cantigi & 62,111 & 32.056 \\
\hline 23 & Pasekan & 68,382 & 24.269 \\
\hline 24 & Lohbener & 38,087 & 55.015 \\
\hline 25 & Arahan & 34,014 & 32.700 \\
\hline 26 & Losarang & 136,726 & 54.333 \\
\hline 27 & Kandanghaur & 83,728 & 87.085 \\
\hline 28 & Bongas & 49,697 & 47.132 \\
\hline
\end{tabular}




\begin{tabular}{|l|l|l|l|}
13 & Krangkeng & 74,227 & 64.300 \\
\hline 14 & Karangampel & 31,468 & 63.485 \\
\hline 15 & Kedokanbunder & 31,843 & 45.037 \\
\hline 16 & Juntinyuat & 53,858 & 79.081 \\
\hline
\end{tabular}

Sumber : Kabupaten Indramayu Dalam Angka 2017

\begin{tabular}{|r|l|r|r|}
29 & Anjatan & 84,653 & 83.252 \\
\hline 33 & Sukra & 44,334 & 44.128 \\
\hline 31 & Patrol & 42,754 & 56.054 \\
\hline & Jumlah & $\mathbf{2 . 0 9 9 , 4 2}$ & $\mathbf{1 . 7 2 8 . 0 4 9}$ \\
\hline
\end{tabular}

Persebaran penduduk Kabupaten Indramayu per Kecamatan hingga pada Tahun 2016 masih menunjukkan kondisi kurang merata. Penduduk terbesar terdapat di Kecamatan Indramayu yaitu sebanyak 111.626 jiwa. Kepadatan penduduk di masing-masing Kecamatan juga menunjukkan ketidakmerataan. Kepadatan penduduk tertinggi juga di Kecamatan Indramayu. Hal ini disebabkan karena Kecamatan Indramayu merupakan Ibukota Kabupaten, yang mana banyak terdapat pusat-pusat kegiatan.

Kabupaten Indramayu merupakan daerah hilir dari aliran sungai-sungai yang sangat potensial sebagai sumber air bagi kebutuhan masyarakat, baik untuk kepentingan usaha pertanian, usaha industri maupun bahan baku air bersih. Daerah Aliran Sungai (DAS) tersebut yaitu Cipunegara, Cipancuh, Sewo, Mang Setan, Bugel, Legok, Eretan, Cilet, Tuan, Cilalanang, Cipanas, Cipondoh, Cibelerang, Pangkalan, Semak, Maja, Rambatan, Cimanuk, Prawiro Kepolo, Prawiro Darung, Gebang Sawit, Glayem, Kamal, Sigedang, Bobos, Oyoran, Pamengkang, Cimanis, dan Kumpulkuista. Dengan banyaknya sungai-sungai yang mengalir melalui Kabupaten Indramayu, akan membawa banyak material ke muara-muara sungai. Material-material yang terbawa sungai tersebut akan sangat berpotensi menjadikan adanya tanah timbul di sepanjang pantai.

\subsubsection{Kondisi Fisik Wilayah}

Kabupaten Indramayu merupakan daerah hilir dari aliran sungai-sungai yang sangat potensial sebagai sumber air bagi kebutuhan masyarakat, baik untuk kepentingan usaha pertanian, usaha industri maupun bahan baku air bersih. Daerah Aliran Sungai tersebut yaitu Cipunegara, Cipancuh, Sewo, Mang Setan, Bugel, Legok, Eretan, Cilet, Tuan, Cilalanang, Cipanas, Cipondoh, Cibelerang, Pangkalan, Semak, Maja, Rambatan, Cimanuk, Prawiro Kepolo, Prawiro Darung, Gebang Sawit, Glayem, Kamal, Sigedang, Bobos, Oyoran, Pamengkang, Cimanis, dan Kumpulkuista.

Ketinggian wilayah pada umumnya berkisar antara 0 - 18 meter diatas permukaan laut. Wilayah dataran rendahnya berkisar antara 0 - 6 meter diatas permukaan laut berupa rawa, tambak, sawah, pekarangan, dan lain sebagainya. Wilayah dataran rendah menempati bagian terluas dari total wilayah yang terletak di sebelah Utara dan Timur. Sebagian besar permukaan tanahnya berupa dataran dengan kemiringan antara 0\% - 2\% seluas $201.285 \mathrm{Ha}$ atau $96,03 \%$ dari total luas wilayah.

Secara geomorfologi, wilayah Kabupaten Indramayu terbagi menjadi daerah perbukitan rendah bergelombang dan dataran rendah. Perbukitan rendah bergelombang menempati daerah sempit di bagian Barat Daya membentuk perbukitan yang memanjang dengan arah Barat Laut sampai Tenggara, sedangkan dataran rendah menempati bagian tengah sampai ke Utara. 


\subsubsection{Kondisi Sosial Ekonomi Wilayah}

Sektor pertanian masih merupakan sektor yang cukup dominan dalam pembangunan perekonomian di Kabupaten Indramayu. Hasil pertanian yang terdiri dari pertanian tanaman pangan, perkebunan, peternakan, kehutanan, dan perikanan merupakan potensi wilayah yang digunakan untuk pemenuhan kebutuhan masyarakat dan sisanya diekspor ke luar wilayah. Selain hasilnya sebagai sumber pemenuhan kebutuhan, sektor pertanian juga merupakan salah satu mata pencaharian utama penduduk di Kabupaten Indramayu

Sesuai dengan letaknya yang berada di pesisir pantai, Indramayu merupakan salah satu Kabupaten penghasil ikan. Produksi ikan laut segar selama tahun 2014 mencapai 126.782,92 ton. Nilai Produksinya mengalami peningkatan dari Rp. 1.829.994.727,03,- pada tahun 2013 menjadi Rp. 2.139.360.709,60,- pada tahun 2014. Kabupaten Indramayu memiliki pulau-pulau kecil sebagai Kawasan Konservasi Laut Daerah (KKLD) yaitu Pulau Biawak, Pulau Gosong dan Pulau Candikian.

Sektor Industri merupakan salah satu sektor yang kini banyak dilirik masyarakat sebagai sarana untuk berusaha dalam menghadapi era otonomi daerah. Keadaan ini bisa terlihat dari meningkatnya jumlah perusahaan industri di Kabupaten Indramayu, jumlah perusahaan industri kecil dan menengah andalan pada tahun 2014 tercatat sebanyak 6.433 unit usaha dengan jumlah tenaga kerja sebanyak 21.269 orang.

Salah satu potensi bidang pertambangan dan energi adalah Minyak Gas dan Bumi dimana Kabupaten Indramayu merupakan daerah yang terbentuk dari endapan.laut dan pantai berjuta tahun silam yang didalamnya mengandung minyak dan gas yang cukup potensial. PT. Pertamina merupakan perusiahaan Nasional yang menguasai eksplorasi, pengolahan dan produksi minyak dan gas bumi dengan wilayah kerja untuk Eksplorasi dan Produksi (EP III) di Mundu Cirebon, dan Unit Pengolahan (UP VI) di Balongan Indramayu. PT. Pertamina (Persero) Refinery Unit VI Balongan beroperasi sejak tahun 1994 berlokasi di Kecamatan Balongan Kabupaten Indramayu yang memasok kebutuhan produk unggulan BBM seperti Premium, Solar, Minyak Tanah, dan BBK seperti Pertamax, Pertamax Plus, Pertamina DEX, LPG dan Propylene serta gas ke DKI Jakarta, Banten dan Jawa Barat. PT. Pertamina (Persero) Refinery Unit VI Balongan mempunyai kontribusi besar dalam menjaga kestabilan pasokan bahan bakar.

Potensi lainnya dalam hal energi adalah Ketenagalistrikan dimana penyediaan tenaga listrik untuk Kabupaten Indramayu dilakukan oleh PT PLN (Persero) UPJ Indramayu melalui 3 (tiga) Gardu Induk. Ketiga Gardu Induk tersebut melayani kebutuhan listrik untuk berbagai sector usaha dan jasa serta seluruh masyarakat sampai ke pelosok desa.

\subsubsection{Penggunaan Tanah}

Kondisi penggunaan tanah Tahun 2015, sawah irigasi 2x padi/ tahun yang paling dominan yaitu seluas $133.106,437 \mathrm{Ha}(63,402 \%)$. Dibanding data penggunaan tanah tahun 2009 sawah irigasi 2x padi/ tahun mengalami penambahan sebesar 15.099,557 Ha, sedangkan penggunaan tanah pedesaan yang meliputi: empang, kebun campuran, kebun sejenis, perkebunan besar, peternakan, sawah irigasi 1x padi/ tahun, sawah irigasi $2 \mathrm{x}$ padi/ tahun, tambak, dan tegalan/ladang mengalami penambahan pada tahun 2015 menjadi 180.659,384 $\mathrm{Ha}(86,05 \%)$, yang berarti terjadi penurunan sebanyak $20.876,153 \mathrm{Ha}$, dan luas penggunaan lainnya seluas $29.282,616 \mathrm{Ha}(13,95 \%)$. 
Tabel 23 Penggunaan Tanah Kabupaten Indramayu Tahun 2015

\begin{tabular}{|c|c|c|c|}
\hline No. & Jenis Penggunana Tanah & Luas ( $\mathrm{Ha})$ & $\%$ \\
\hline 1 & Alang-Alang & 9,721 & 0,005 \\
\hline 2 & Aneka Pangan & 3,323 & 0,002 \\
\hline 3 & Empang & 845,539 & 0,403 \\
\hline 4 & Emplasemen Tetap & 611,669 & 0,291 \\
\hline 5 & Fasilitas Ibadah & 18,228 & 0,009 \\
\hline 6 & Fasilitas Kesehatan & 4,084 & 0,002 \\
\hline 7 & Fasilitas Pendidikan & 121,559 & 0,058 \\
\hline 8 & Gardu & 0,531 & 0,000 \\
\hline 9 & Hutan Sejenis & $2.728,382$ & 1,300 \\
\hline 10 & Industri & 171,859 & 0,082 \\
\hline 11 & Industri Kimia & 24,496 & 0,012 \\
\hline 12 & Jalan Tol & 113,277 & 0,054 \\
\hline 13 & Kampung Jarang & $1.378,041$ & 0,656 \\
\hline 14 & Kampung Padat & $17.813,687$ & 8,485 \\
\hline 15 & Kebun Campuran & $3.241,100$ & 1,544 \\
\hline 16 & Kebun Sejenis & 271,747 & 0,129 \\
\hline 17 & Komplek Militer & 3,473 & 0,002 \\
\hline 18 & Lapangan Olahraga & 26,222 & 0,012 \\
\hline 19 & Makam Khusus & 0,428 & 0,000 \\
\hline 20 & Makam Pahlawan & 1,126 & 0,001 \\
\hline 21 & Makam Umum & 142,455 & 0,068 \\
\hline 22 & Padang Rumput/Sabana & 78,936 & 0,038 \\
\hline 23 & Pasar & 50,413 & 0,024 \\
\hline 24 & Pasir Pantai & 266,798 & 0,127 \\
\hline 25 & Pelabuhan & 3,057 & 0,001 \\
\hline 26 & Perairan Dangkal & 243,300 & 0,116 \\
\hline 27 & Pergudangan & 19,430 & 0,009 \\
\hline 28 & Perkebunan Besar & $8.384,547$ & 3,994 \\
\hline 29 & Pertambangan Terbuka & 142,322 & 0,068 \\
\hline 30 & Pertambangan Tertutup & 193,170 & 0,092 \\
\hline 31 & Pertamina & 354,064 & 0,169 \\
\hline 32 & Perumahan Jarang & 369,230 & 0,176 \\
\hline 33 & Perumahan Padat & 317,409 & 0,151 \\
\hline 34 & Peternakan & 146,119 & 0,070 \\
\hline 35 & PLTA/PLTU & 64,322 & 0,031 \\
\hline 36 & Rawa & 0,140 & 0,000 \\
\hline 37 & $\begin{array}{l}\text { Sawah Irigasi 1x } \\
\text { Padi/Tahun }\end{array}$ & $4.621,379$ & 2,201 \\
\hline 38 & $\begin{array}{l}\text { Sawah Irigasi } 2 x \\
\text { Padi/Tahun }\end{array}$ & $133.106,437$ & 63,402 \\
\hline 39 & Semak & 157,748 & 0,075 \\
\hline 40 & Situs Sejarah & 0,114 & 0,000 \\
\hline 41 & Sungai/Danau/Situ/Telaga & $3.640,944$ & 1,734 \\
\hline 42 & Taman & 2,534 & 0,001 \\
\hline 43 & Tambak & $20.635,295$ & 9,829 \\
\hline 44 & Tanah Rusak & 9,217 & 0,004 \\
\hline 45 & Tanah Terbuka Sementara & 192,221 & 0,092 \\
\hline 46 & Tegalan/Ladang & $9.407,220$ & 4,481 \\
\hline 47 & Waduk & 4,687 & 0,002 \\
\hline \multicolumn{2}{|c|}{ JUMLAH } & $209.942,000$ & 100,000 \\
\hline
\end{tabular}

Ket : Luas yang digunakan berdasarkan hasil digitas peta

Sumber : Olahan Peta Penggunaan Tanah Kabupaten Indramayu Tahun 2015 


\subsubsection{Penguasaan Tanah}

Berdasarkan data pada Tabel 24 dapat diketahui bahwa gambaran umum penguasaan tanah di Kabupaten Indramayu terluas adalah tanak hak UUPA/ulayat seluas 163.549,433 Ha atau $77,90 \%$ dari luas wilayah, terluas kedua selanjutnya adalah hutan produksi seluas $31.473,998 \mathrm{Ha}$ atau $14,99 \%$, sedangkan terkecil adalah tanah yang dikuasai oleh badan hukum yaitu seluas $449,095 \mathrm{Ha}$.

Tabel 24 Penguasaan Tanah Kabupaten Indramayu Tahun 2015

\begin{tabular}{|l|l|r|r|}
\hline No. & Jenis Penguasaan Tanah & Luas (Ha) & \multicolumn{1}{|c|}{ \% } \\
\hline 1 & Badan Hukum & 449,095 & 0,21 \\
\hline 2 & Hak Guna Usaha & 641,870 & 0,31 \\
\hline 3 & Hak Milik/Perorangan & $2.706,288$ & 1,29 \\
\hline 4 & Hutan Lindung & $7.367,096$ & 3,51 \\
\hline 5 & Hutan Produksi & $31.473,998$ & 14,99 \\
\hline 6 & Jalan Tol & 113,277 & 0,05 \\
\hline 7 & Sungai/Danau/Situ/Telaga & $3.640,944$ & 1,73 \\
\hline 8 & Tanah Hak UUPA/Ulayat & $163.549,433$ & 77,90 \\
\hline JUMLAH & $\mathbf{2 0 9 . 9 4 2 , 0 0 0}$ & $\mathbf{1 0 0 , 0 0}$ \\
\hline
\end{tabular}

Ket : Luas yang digunakan berdasarkan hasil digitas peta

Sumber: Olahan Peta GUPT Kabupaten Indramayu Tahun 2015

\subsection{Kabupaten Serang}

Kabupaten Serang ada salah satu kabupaten di Provinsi Banten yang terletak di sebelah utara, yang berbatasan dengan Laut Jawa.Di smping itu Kabupaten Serang juga berbatasan dengan Selat Sunda, yaitu selat yang menghubungkan Pulau Jawa dengan Pulau Sumatra. Wilayah Kabupaten Serang terdiri dari 29 Kecamatan dan 326 Desa/Kelurahan, Selain itu, perairan Kabupaten Serang juga terdapat 16 pulau diantaranya adalah Pulau Sangiang, Pulau Salira, Pulau Kali, Pulau Tarahan, Pulau Kemanisan, Pulau Cikatung, Pulau Panjang, Pulau Semut, Pulau Kubur, Pulau Lima, Pulau Gedang, Pulau Dua (Burung), Pulau Satu, Pulau Pamujan Besar, Pulau Pamujan Kecil dan Pulau Tunda (Babi). 


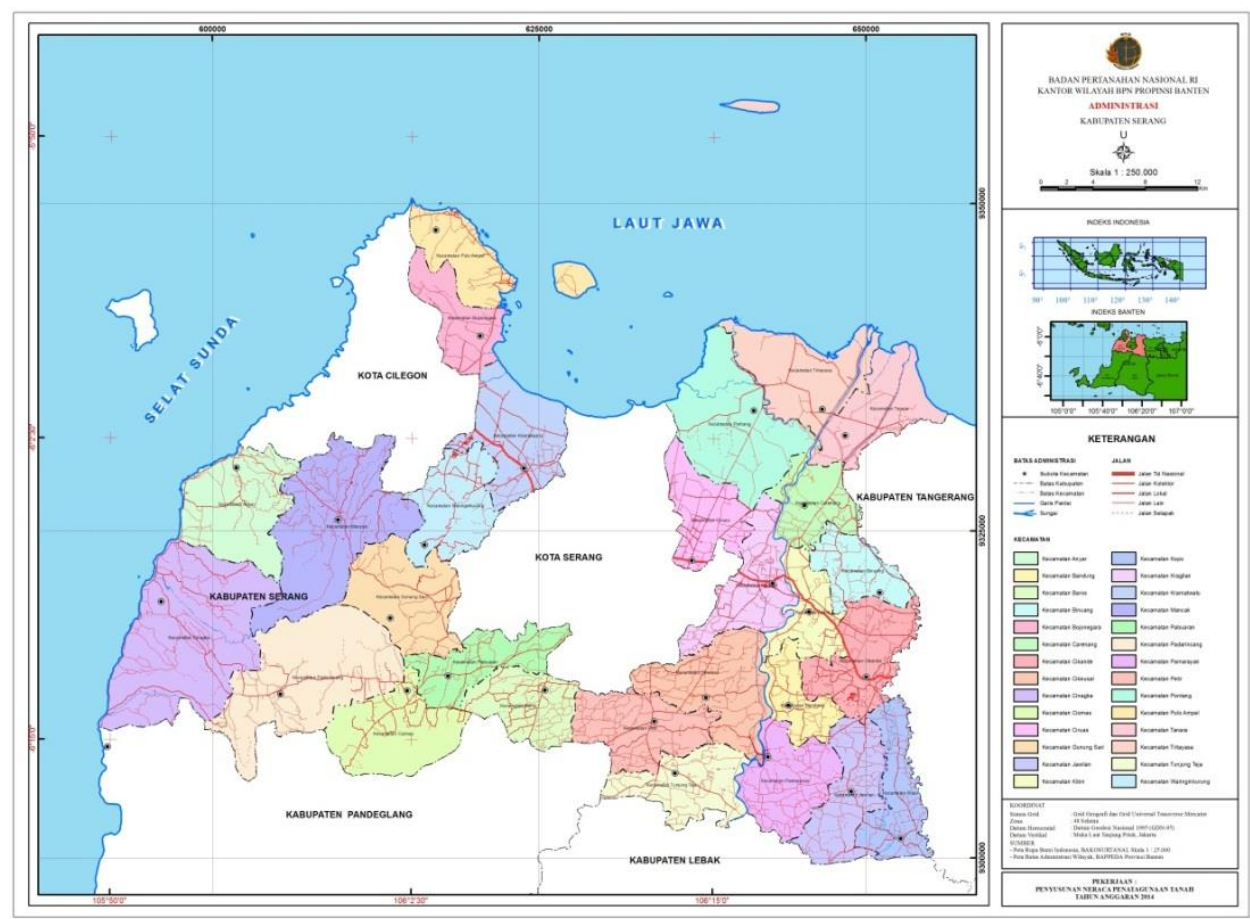

Sumber : Kanwil BPN Provinvi Banten

Gambar 11. Peta Administrasi Kabupaten Serang

\subsubsection{Kondisi Fisik Wilayah}

Berdasarkan letak geografisnya, wilayah Kabupaten Serang berada pada posisi $105^{\circ} 49^{\prime}$ 30,14"- 106²4' 43,38" Bujur Timur dan 548' 26,71" - 6²0' 8,99” Lintang Selatan, yang dibatasi oleh:

Sebelah Utara : berbatasan dengan wilayah Kota Serang dan Laut Jawa

Sebelah Barat : berbatasan dengan wilayah Kota Cilegon dan Selat Sunda.

Sebelah Selatan : berbatasan dengan wilayah KabupatenPandeglang dan Lebak.

Sebelah Timur : berbatasan dengan Kabupaten Tangerang.

Kabupaten Serang mempunyai luas $1.467,35 \mathrm{~km}^{2}$, dengan jumlah penduduk 1.484 .502 jiwa, maka kepadatan penduduknya adalah 1.012 jiwa tiap km².

Sumber-sumber air yang ada di Kabupaten Serang berasal dari air permukaan dan air bawah tanah. Sumber air permukaan berasal dari banyak sungai seperti : Sungai Ciujung, Cidurian, Cibanten, Cipaseuran, Cipasang, Anyar, dan lain-lain. Sungai-sungai yang terdapat di Kabupaten Serang memiliki lebar yang relatif kecil, yaitu dengan lebar kurang dari 50 meter, dan pendek, yaitu dengan panjang kurang dari 100 kilometer. Sungai-sungai yang terdapat di wilayah Kabupaten Serang sebagian besar berhulu di bagian Selatan. Sedangkan untuk arah aliran airnya, sebagian besar mengalir ke utara, yaitu ke Laut Jawa / Teluk Banten, dan sebagian kecil mengalir ke arah barat, yaitu ke Selat Sunda, Sungai-sungai besar yang ada membentuk Daerah Aliran Sungai (DAS) yaitu DAS Cidurian, DAS Ciujung, DAS Cibanten dan DAS Cidanau. 


\subsubsection{Kondisi Sosial Ekonomi Wilayah}

Struktur ekonomi Kabupaten Serang terbesar pada industry pengolahan dan pertanian, terdapatnya industry pengolahan membuka lapangan pekerjaan bagi masyarakat setempat. Pusat kawasan industry terdapat di kawasan Bojonegara dan Serang Timur khususnya di kawasan Cikande. Selain kawasan Cikande, yang menjadi prioritas dalam pengembangan potensi ekonomi adalah Kawasan Ekonomi Khusus (KEK) Bojonegara. KEK meliputi Bojonegara, Puloampel dan Kramatwatu.

Berdasarkan PDRB Kabupaten Serang tahun 2012 Perekonomian Kabupaten Serang pada tahun 2012 tumbuh 5,10 persen, artinya secara agregat kuantitas output perekonomiannya meningkat sebesar 5,10 persen dibandingkan tahun sebelumnya. Apabila dibandingkan dengan laju pertumbuhan ekonomi tahun 2011 yang dikoreksi sebesar 5,18 persen maka perkembangan perekonomian Kabupaten Serang sepanjang peroide 2011 - 2012 secara riil mengalami perlambatan disbanding periode $2010-2011$.

Pembangunan ekonomi yang bertujuan mensejahterakan masyarakatnya nampak masih mengalami berbagai kendala.Tampak pada tahun 2014 jumlah keluarga yang tergolong pra sejahtera menurun hanya sebesar 1,86 persen. Kini tercatat keluarga pra sejahtera masih sebanyak 83,89 ribu keluarga, sedangkan pada tahun sebelumnya mencapai 85,48 ribu keluarga.

\subsubsection{Penggunaan Tanah}

Penggunaan Tanah di wilayah Kabupaten Serang tahun 2014 ini sebagian besar masih merupakan sawah irigasi yaitu sekitar 60.273,37 atau 41,21\% dari luas Wilayah Kabupaten Serang dan Kecamatan Pontang merupakan Kecamatan yang paling luas penggunaan tanahnya berupa Kebun Campuran yaitu seluas 4.987,83 ha. Penggunaan tanah berupa kebun campuran mengalami pengurangan luas yaitu sekitar $9.463,39$ ha atau 13,57 \% dibandingkan data penggunaan tanah tahun 2009, hal tersebut dikarenakan adanya alih fugsi lahan.

Tabel 25. Penggunaan Tanah Kabupaten SerangTahun 2014

\begin{tabular}{|c|l|r|r|}
\hline No & Penggunaan Tanah & \multicolumn{1}{|c|}{ Luas (Ha) } & \% Luas Wilayah \\
\hline 1 & Bandar Udara & 38,10 & $0,03 \%$ \\
\hline 2 & Hutan Belukar & $3.190,13$ & $6,28 \%$ \\
\hline 3 & Hutan Rawa & $1.822,08$ & $0,24 \%$ \\
\hline 4 & Industri/Pergudangan & $33.000,40$ & $1,25 \%$ \\
\hline 5 & Kebun Campuran & $8.040,11$ & $22,56 \%$ \\
\hline 6 & Ladang/Tegalan & $1.990,87$ & $5,50 \%$ \\
\hline 7 & Padang Rumput & $1.857,50$ & $1,36 \%$ \\
\hline 8 & Perkampungan Jarang & & $1,27 \%$ \\
\hline
\end{tabular}




\begin{tabular}{|r|l|r|r|}
\hline 9 & Perkampungan Padat & $10.758,93$ & $7,36 \%$ \\
\hline 10 & Perkebunan Besar & 397,91 & $0,27 \%$ \\
\hline 11 & Perumahan Jarang & 36,36 & $0,02 \%$ \\
\hline 12 & Perumahan Padat & 314,82 & $0,22 \%$ \\
\hline 13 & Rawa & $1.459,79$ & $1,00 \%$ \\
\hline 14 & Sawah Irigasi & $60.273,37$ & $41,21 \%$ \\
\hline 15 & Sawah Tadah Hujan & $1.313,69$ & $0,90 \%$ \\
\hline 16 & Semak Belukar & $6.592,35$ & $4,51 \%$ \\
\hline 17 & Sungai/Danau/Telaga & $1.158,47$ & $0,79 \%$ \\
\hline 18 & Tambak & $7.078,02$ & $4,84 \%$ \\
\hline 19 & Tanah Kosong & $\mathbf{1 4 6 . 2 6 9 , 2 8}$ & $\mathbf{1 0 0 , 0 0 \%}$ \\
\hline & Total & & $\mathbf{1 0 0} \%$ \\
\hline
\end{tabular}

Sumber : Updating Data Penatagunaan Tanah Tahun 2014

Dari segi penggunaan tanahnya terlihat wilayah Kabupaten Serang didominasi oleh penggunaan tanah pertanian (Sawah Irigasi, Sawah Tadah Hujan, Perkebunan Besar, Kebun Campuran, Ladang/ Tegalan dan Tambak) yaitu seluas $110.103,51 \mathrm{Ha}$. atau $75,27 \%$ dari luas wilayah Kabupaten Serang. Terutama penggunaan tanah Sawah Irigasi yaitu seluas 60.273,37 Ha. atau $41,21 \%$ dari luas wilayah Kabupaten Serang.

\subsubsection{Penguasaan Tanah}

Hasil identifikasi di Kabupaten Serang terdapat 2 kelompok jenis penguasaan tanah, seperti dapat dilihat pada tabel berikut.

Tabel 26. Penguasaan Tanah Kabupaten Serang Per Kecamatan

\begin{tabular}{|c|c|c|c|c|c|}
\hline \multirow{2}{*}{ No } & \multirow{2}{*}{ Kecamatan/ Desa } & \multicolumn{2}{|c|}{$\begin{array}{c}\text { Gambaran Umum Penguasaan } \\
\text { Tanah }\end{array}$} & \multicolumn{2}{|c|}{ Jumlah } \\
\hline & & $\begin{array}{c}\text { Tanah } \\
\text { Kehutanan }\end{array}$ & $\begin{array}{c}\text { Tanah Hak } \\
\text { Milik }\end{array}$ & Luas (Ha) & \% Wilayah \\
\hline 1 & Anyar & $1.691,02$ & $5.271,42$ & $6.962,44$ & $4,76 \%$ \\
\hline 2 & Bandung & & $2.525,21$ & $2.525,21$ & $1,73 \%$ \\
\hline 3 & Baros & & $3.763,19$ & $3.763,19$ & $2,57 \%$ \\
\hline 4 & Binuang & & $2.936,17$ & $2.936,17$ & $2,01 \%$ \\
\hline \multirow{2}{*}{ No } & \multirow{2}{*}{ Kecamatan/ Desa } & \multicolumn{2}{|c|}{$\begin{array}{c}\text { Gambaran Umum Penguasaan } \\
\text { Tanah }\end{array}$} & \multicolumn{2}{|c|}{ Jumlah } \\
\hline & & $\begin{array}{c}\text { Tanah } \\
\text { Kehutanan }\end{array}$ & $\begin{array}{l}\text { Tanah Hak } \\
\text { Milik }\end{array}$ & Luas (Ha) & $\%$ Wilayah \\
\hline 5 & Bojonegara & 334,80 & $3.001,08$ & $3.335,88$ & $2,28 \%$ \\
\hline 6 & Carenang & & $3.303,86$ & $3.303,86$ & $2,26 \%$ \\
\hline 7 & Cikande & & $4.854,16$ & $4.854,16$ & $3,32 \%$ \\
\hline
\end{tabular}




\begin{tabular}{|r|l|r|r|r|r|}
\hline 8 & Cikeusal & & $5.692,11$ & $5.692,11$ & $3,89 \%$ \\
\hline 9 & Cinangka & 697,98 & $12.019,83$ & $12.717,81$ & $8,69 \%$ \\
\hline 10 & Ciomas & $1.499,36$ & $4.005,18$ & $5.504,54$ & $3,76 \%$ \\
\hline 11 & Ciruas & & $4.324,72$ & $4.324,72$ & $2,96 \%$ \\
\hline 12 & Gunung Sari & $1.421,74$ & $4.076,44$ & $5.498,18$ & $3,76 \%$ \\
\hline 13 & Jawilan & & $4.438,42$ & $4.438,42$ & $3,03 \%$ \\
\hline 14 & Kibin & & $2.995,27$ & $2.995,27$ & $2,05 \%$ \\
\hline 15 & Kopo & & $3.786,25$ & $3.786,25$ & $2,59 \%$ \\
\hline 16 & Kragilan & 180,70 & $5.457,66$ & $4.457,66$ & $3,05 \%$ \\
\hline 17 & Kramatwatu & $2.625,06$ & $7.315,16$ & $5.495,87$ & $3,76 \%$ \\
\hline 18 & Mancak & 0,00 & $3.826,67$ & $9.666,50$ & $6,61 \%$ \\
\hline 19 & Pabuaran & $3.226,86$ & $6.685,93$ & $9.826,68$ & $2,62 \%$ \\
\hline 20 & Padarincang & & $4.566,24$ & $4.566,24$ & $6,78 \%$ \\
\hline 21 & Pamarayan & & $4.787,88$ & $4.787,88$ & $3,12 \%$ \\
\hline 22 & Petir & & $7.792,27$ & $7.792,27$ & $3,27 \%$ \\
\hline 23 & Pontang & $1.038,06$ & $3.111,26$ & $4.149,32$ & $2,84 \%$ \\
\hline 24 & Pulo Ampel & & $4.492,46$ & $4.492,46$ & $3,07 \%$ \\
\hline 25 & Tanara & & $5.887,67$ & $5.887,67$ & $4,03 \%$ \\
\hline 26 & Tirtayasa & & $4.190,64$ & $4.190,64$ & $2,87 \%$ \\
\hline 27 & Tunjung Teja & 41,89 & $4.363,20$ & $4.405,09$ & $3,01 \%$ \\
\hline 28 & Waringinkurung & $\mathbf{1 2 . 7 5 7 , 4 8}$ & $\mathbf{1 3 3 . 5 1 1 , 8 1}$ & $\mathbf{1 4 6 . 2 6 9 . 2 8}$ & $\mathbf{1 0 0 , 0 0 \%}$ \\
\hline & TOTAL & $\mathbf{1 3 2}$ & & \\
\hline
\end{tabular}

Sumber : Hasil Inventarisasi Data Penatagunaan Tanah Tahun 2014

Gambaran Umum Penguasaan Tanahnya dapat diketahui bahwa penguasaan tanah terluas di Kabupaten Serang berupa Tanah Hak Milik seluas 133.511,81 Ha. atau 91,28 \% dan sisanya adalah Tanah Kehutanan yaitu seluas 12.757,48 Ha.atau 8,72 \%.

\subsection{Kabupaten Tangerang}

Kabupaten Tangerang ada salah satu kabupaten di Provinsi Banten yang terletak di sebelah utara, yang berbatasan dengan Laut Jawa. Di samping itu, Kabupaten Tangerang juga berbatasan dengan Daerah Khusus Ibukota Jakarta, sehingga menyebabkan daerah ini mempunyai pertumbuhan yang sangat pesat.

Pada awal tahun 2000, pusat pemerintahan Kabupaten Tangerang pun di pindahkan Bupati H. Agus Djunara ke Ibukota Tigaraksa. Pemindahan ini dinilai strategis dalam upaya memajukan daerah karena bertepatan dengan penerapan otonomi daerah, diberlakukannya perimbangan keuangan pusat dan daerah, adanya revisi pajak dan retribusi daerah, serta terbentuknya Provinsi Banten. 


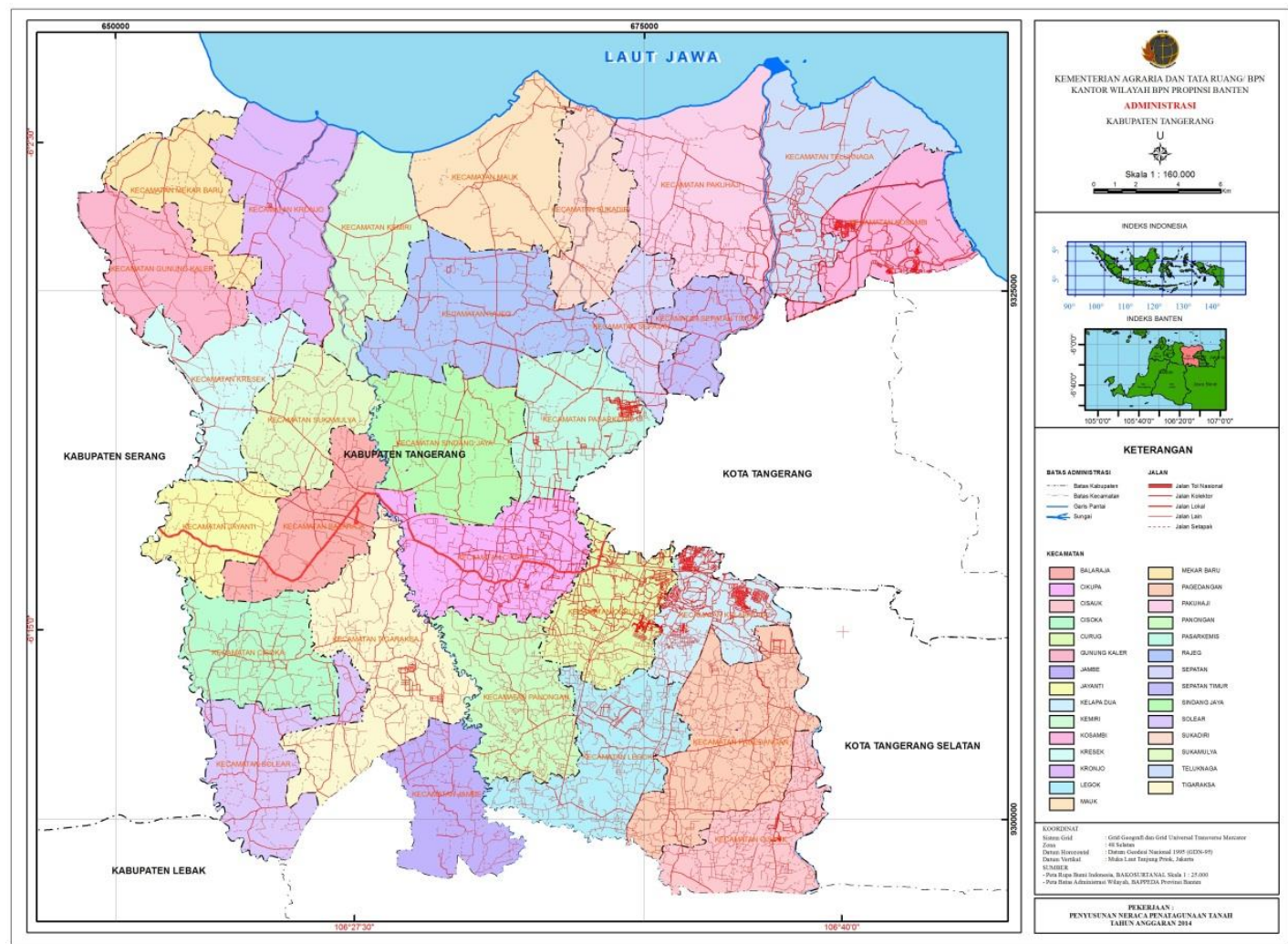

Sumber : Kanwil BPN Provinvi Banten

Gambar 12. Peta Administrasi Kabupaten Tangerang

\subsubsection{Kondisi Geografis Wilayah}

Berdasarkan letak geografisnya, wilayah Kabupaten Tangerang berada pada posisi $106^{\circ}$ $20^{\prime} 24,5^{\prime \prime}-106^{\circ} 43^{\prime}$ 5,84" Bujur Timur dan 6 0' 17,64" - 6 $21^{\circ}$ ' 46,18" Lintang Selatan, yang dibatasi oleh:

Sebelah Utara : berbatasan dengan Laut Jawa

Sebelah Barat : berbatasan dengan wilayah Kabupaten Serang

Sebelah Selatan : berbatasan dengan wilayah Kabupaten Lebak dan Kabupaten Bogor (Jawa Barat).

Sebelah Timur : berbatasan dengan wilayah DKI Jakarta, Kota Tangerang, dan Kota Tangerang Selatan.

Kabupaten Tangerang mempunyai luas 959,61 $\mathrm{km}^{2}$, dengan jumlah penduduk 3.477.495 jiwa, maka kepadatan penduduknya adalah 3.624 jiwa tiap $\mathrm{km}^{2}$. Wilayah Kabupaten Tangerang terdiri dari 29 Kecamatan dan 374 Desa/Kelurahan,

Sumber-sumber air yang ada di Kabupaten Tangerang berasal dari air permukaan dan air bawah tanah. Sumber air permukaan berasal dari banyak sungai seperti : Sungai Cimanceuri, Ciranggon, Cileleus, Cimauk, Cirarab, Ciasin, Cisadane dan lain-lain. Sungaisungai yang terdapat di wilayah Kabupaten Tangerang berhulu di bagian Selatan. Sedangkan untuk arah aliran airnya, mengalir ke utara, yaitu ke Laut Jawa. Ada 3 sungai besar yang mengalir di wilayah kabupaten Tangerang, antara lain : Cisadane, Cimanceuri dan Cirarab. 


\subsubsection{Kondisi Ekonomi Sosial Wilayah}

Perekonomian Kabupaten Tangerang didominasi oleh industri pengolahan, perdagangan, hotel dan restoran. Kabupaten Tangerang adalah salah satu kantung industri Indonesia. Terutama karena keberadaannya juga memperkuat pertumbuhan ekonomi daerah dalam wilayah Jabotabek. Kegiatan industri yang menyita lebih dari 50 persen potensi ekonomi daerah setempat memberi peran yang tidak sedikit terhadap daerah lain, terutama yang menyangkut distribusi manusia dan barang, dan sektor lain yang terkait dengan dua hal ini. Di sektor pertanian, kabupaten Tangerang dikenal sebagai lumbung padi. Setelah lahan-lahan persawahan berubah menjadi lahan industri dan pemukiman, luas areal pertanian dan hasil produksi padi terus menurun.

Namun demikian, produksi ini bisa kembali dikembangkan dengan penerapan teknologi budidaya dan industri pengolahan hasil panen tepat guna. Terdapat beberapa jenis tanaman lainnya dengan produksi lebih kecil, yaitu aren, cengkeh, kakao, jahe, jambu mete, kapuk, karet, kenanga, kencur. kopi, kumis kucing, lada, melati, melinjo, mendong, nipah, pandan, pandan wangi, pinang, sereh sayur, sirih, tebu, temu lawak, dan vanili.Di sektor perikanan, Industri pengolahan ikan yang dapat didirikan misalnya industri pengalengan ikan, industri pengasinan dan pengeringan ikan, industri pengasapan ikan.

\subsubsection{Penggunaan Tanah}

Penggunaan tanah di Kabupaten Tangerang cukup beragam. Untuk wilayah dataran, yaitu mengarah ke utara, penggunaan tanahnya didominasi persawahan. Luas areal persawahan lebih dari $50 \%$ wilayah Kabupaten Tangerang. Areal persawahan yang paling banyak berada di Kecamatan Rajeg. Untuk wilayah yang agak terjal, yaitu yang mengarah ke selatan, penggunaan tanahnya cenderung berupa perkebunan dan kebun campuran. Untuk penggunaan permukiman cenderung di wilayah timur, yaitu berbatasan dengan Kota Tangerang. Hal ini disebabkan karena daerah ini dekat dengan pusat-pusat kegiatan di wilayah Kota Tangerang, sehingga penduduk akan bermukim di sekitar tempat tersebut.

Tabel 27.Penggunaan Tanah Kabupaten Tangerang Tahun 2014

\begin{tabular}{|c|l|r|r|}
\hline No & Penggunaan Tanah & Luas (Ha) & \% Wilayah \\
\hline 1 & $\begin{array}{l}\text { Jasa, Industri dan } \\
\text { Pergudangan }\end{array}$ & $1,652.46$ & $1.65 \%$ \\
\hline 2 & Kebun Campuran & $16,676.68$ & $16.61 \%$ \\
\hline 3 & Perairan Darat & $5,856.32$ & $5.83 \%$ \\
\hline 4 & Perkebunan & $2,119.57$ & $2.11 \%$ \\
\hline 5 & Permukiman & $14,194.36$ & $14.14 \%$ \\
\hline 6 & Persawahan & $56,741.24$ & $56.52 \%$ \\
\hline 7 & Pertambangan & 110.11 & $0.11 \%$ \\
\hline 8 & Sungai/danau & 953.07 & $0.95 \%$ \\
\hline 9 & Tanah Terbuka & 63.23 & $0.06 \%$ \\
\hline 10 & Tegalan/Ladang & $2,031.61$ & $2.02 \%$ \\
\hline & Total & $\mathbf{1 0 0 , 3 9 8 . 6 6}$ & $\mathbf{1 0 0 . 0 0 \%}$ \\
\hline
\end{tabular}

Sumber : Kanwil BPN Provinvi Banten 


\subsection{Kota Bengkulu}

Kota Bengkulu yang dalam Bahasa Inggris disebut "Bencoolen" merupakan kota terbesar kedua di pantai barat Pulau Sumatera, setelah Kota Padang. Sebelumnya kawasan ini berada dalam pengaruh Kerajaan Inderapura dan Kesultanan Banten. Selanjutnya dikuasai oleh Inggris sebelum diserahkan kepada Belanda. Kota ini juga pernah menjadi tempat pengasingan presiden pertama Indonesia, Ir. Soekarno dalam kurun tahun 1939 - 1942 pada masa pemerintahan Hindia Belanda. ${ }^{24}$

Berdasarkan sejarahnya, daerah Bengkulu pernah berada di bawah kekuasaan kolonial Inggris, Belanda, dan Jepang (dari tahun 1685 sampai tahun 1945). Sejak tahun 1713, dibangun benteng Marlborough (selesai 1719) yang hingga sekarang masih tegak berdiri. Sejak dilaksanakannya Perjanjian London pada tahun 1824, Bengkulu diserahkan ke Belanda, dengan imbalan Malaka sekaligus penegasan atas kepemilikan Tumasik/Singapura dan Pulau Belitung). ${ }^{[2]}$ Sejak perjanjian itu Bengkulu menjadi bagian dari Hindia Belanda.

Secara resmi, setelah Indonesia merdeka, Keresidenan Bengkulu dibentuk oleh Pemerintah Republik Indonesia pada tanggal 12 Oktober 1945.

\subsubsection{Kondisi Fisik Wilayah}

Kota Bengkulu terletak pada $102^{\circ} 14^{\prime}-102^{\circ} 22^{\prime}$ BT dan pada $30^{\circ} 45^{\prime}-30^{\circ} 59^{\prime}$ LS dengan batas-batas wilayahnya sebagai berikut:
a. Sebelah Utara
: Kabupaten Bengkulu Tengah
b. Sebelah Timur
: Kabupaten Bengkulu Tengah
c. Sebelah Selatan
: Kabupaten Seluma
d. Sebelah Barat
: Samudera Hindia

Secara administratif Kota Bengkulu terbagi menjadi 9 (sembilan) kecamatan yaitu Kecamatan Gading Cempaka, Kampung Melayu, Muara Bangkahulu, Ratu Agung, Ratu Samban, Selebar, Singaran Pati, sungai Serut dan Teluk Segara.

Tabel 28. Pembagian administrasi Kota Bengkulu

\begin{tabular}{|c|l|r|r|}
\hline \multirow{2}{*}{ No } & \multirow{2}{*}{ Kecamatan } & \multicolumn{2}{|c|}{ Luas } \\
\cline { 3 - 4 } & & \multicolumn{1}{|c|}{ Ha } \\
\hline 1 & & 627,91 & \multicolumn{1}{|c|}{4,11} \\
2 & Gading Cempaka & $3.533,76$ & 23,11 \\
3 & Kampung Melayu & $2.258,80$ & 14,77 \\
4 & Ruara Bangkahulu & $1.119,22$ & 7,32 \\
5 & Ratu Samban & 293,15 & 1,92 \\
6 & Selebar & $4.301,25$ & 28,13
\end{tabular}

${ }^{24}$ https://id.wikipedia.org/wiki/Kota_Bengkulu 


\begin{tabular}{|c|l|r|r|}
7 & Singaran Pati & $1.035,31$ & 6,77 \\
8 & Sungai Serut & 743,46 & 4,86 \\
10 & Teluk Segara & 255,52 & 1,67 \\
11 & Perairan & $1.124,51$ & 7,35 \\
\hline \multicolumn{2}{|c|}{ Total } & $15.292,89$ & 100 \\
\hline
\end{tabular}

Sumber: Kanwil BPN Provinsi Bengkulu

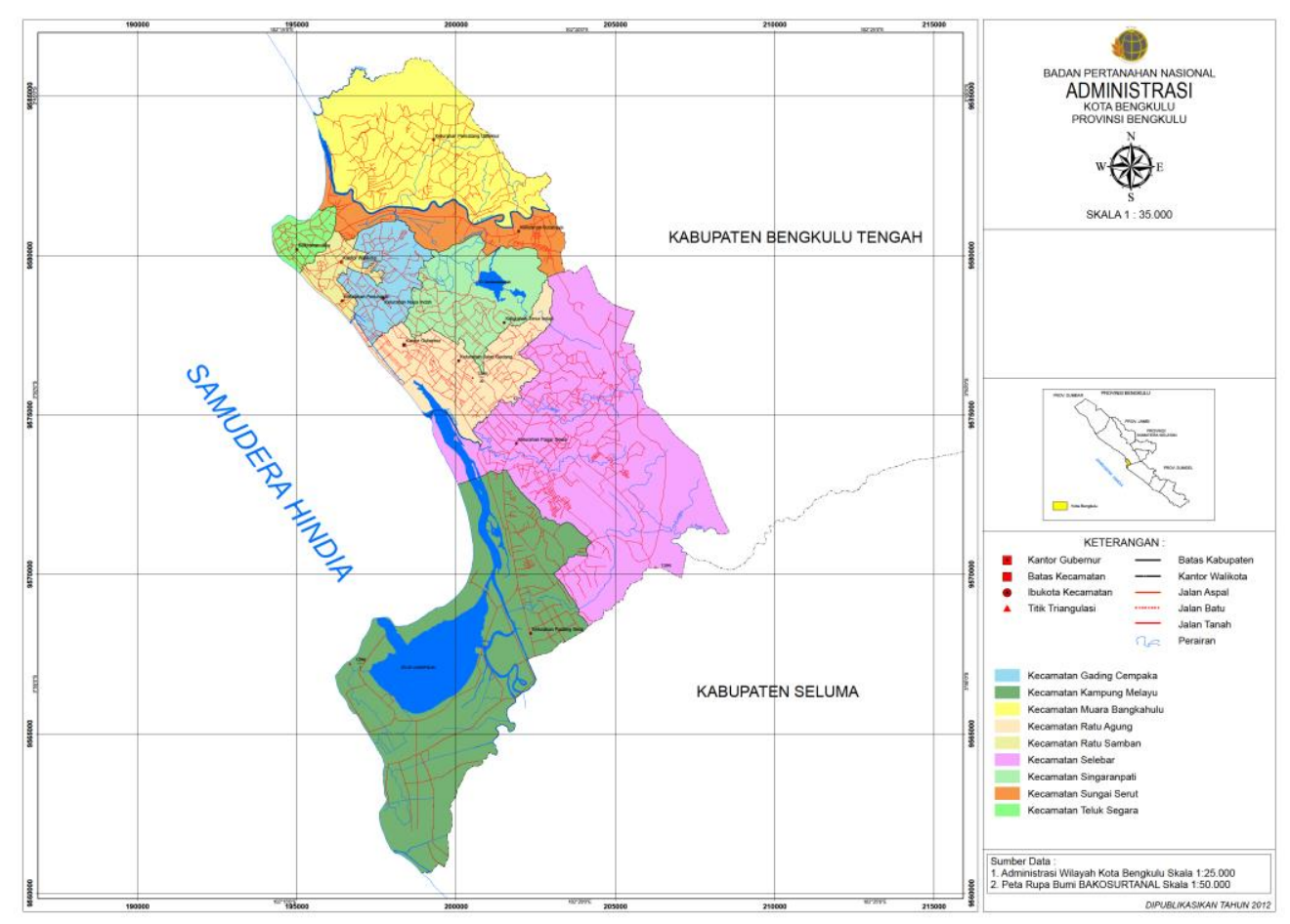

Sumber: Kanwil BPN Provinsi Bengkulu

Gambar 13. Peta Administrasi Kota Bengkulu

\subsubsection{Kondisi Sosial Ekonomi Wilayah}

Dalam hal kependudukan, jumlah penduduk Kota Bengkulu berdasarkan hasil dari Badan Pusat Statistik (BPS) sampai tahun 2011 tercatat sebanyak 308.544 jiwa dengan kepadatan penduduk $2.018 \mathrm{jiwa} / \mathrm{Km}^{2}$. 155.288 jiwa diantaranya adalah laki-laki sedangkan jumlah penduduk perempuan sebanyak 153.255 jiwa. Kecamatan dengan penduduk terbanyak adalah Kecamatan Gading Cempaka (masih menjadi satu dengan Kecamatan Singaran Pati) memiliki jumlah penduduk terbanyak yaitu 78.787 jiwa sedangkan kecamatan yang jumlah penduduknya paling sedikit Kecamatan Sungai Serut yaitu 21.981 jiwa.

Mata pencaharian masyarakat Kota Bengkulu sebagian besar adalah di sektor jasa dan perdagangan. Data pada Neraca Penatagunaan Tanah yang bersumber dari BPS tahun 2011 menyebutkan persentase penduduk 15 tahun ke atas di Kota Bengkulu yang bekerja di sektor ini pada tahun 2010 adalah 35,9\%. Sektor selanjutnya adalah sektor perikanan, pertanian dan perkebunan yang berupa padi, sayur-sayuran, palawija, kelapa sawit, dan karet. 


\subsubsection{Penggunaan Tanah}

Penggunaan tanah pada Tahun 2012 seluas $73,10 \%$ penggunaan tanahnya adalah penggunaan tanah budidaya atau seluas $11.179,06 \mathrm{Ha}$. Kota Bengkulu didominasi oleh tanah yang sudah diusahakan penduduk terdiri dari perumahan tidak teratur seluas $3.792,12 \mathrm{Ha}$ $(24,80 \%)$. Untuk Perairan berdasarkan klasifikasi penggunaan tanah skala 1:25.000 terdiri dari bendungan, sungai, danau, telaga, dan rawa memiliki luas 2.033,55 Ha atau 13,30\%.

Tabel 29. Penggunaan Tanah Kota Bengkulu Tahun 2012

\begin{tabular}{|c|l|r|r|}
\hline No & \multicolumn{1}{|c|}{ Penggunaan Tanah } & Luas (Ha) & \multicolumn{2}{|c|}{\begin{tabular}{c} 
Wualayah \\
\hline 1
\end{tabular}} & Hutan Sejenis & 361,02 & 2,36 \\
2 & Jalur Hijau & 465,01 & 3,04 \\
3 & Jasa Pemerintahan & 21,23 & 0,14 \\
4 & Jasa Pendidikan & 10,08 & 0,07 \\
5 & Kebun Campuran & 1677,18 & 10,97 \\
6 & Kebun Sejenis & 2036,06 & 13,31 \\
7 & Pemakaman & 0,92 & 0,01 \\
8 & Perikanan & 264,54 & 1,73 \\
9 & Perumahan Teratur & 322,43 & 2,11 \\
10 & Perumahan Tidak Teratur & 3792,12 & 24,80 \\
11 & Prasarana Transport & 103,47 & 0,68 \\
12 & Sawah Irigasi 2xpadi/th & 417,18 & 2,73 \\
13 & Sawah Tadah Hujan & 4,27 & 0,03 \\
14 & Semak & 1254,26 & 8,20 \\
15 & Tanah Industri & 47,09 & 0,31 \\
16 & Tanah Jasa & 58,82 & 0,38 \\
17 & Tanah Perusahaan & 232,40 & 1,52 \\
18 & Tanah Terbuka Sementara & 342,73 & 2,24 \\
19 & Tegalan/Ladang & 1848,52 & 12,09 \\
20 & Perairan & 2033,55 & 13,30 \\
\hline & & $15.292,89$ & 100,00 \\
\hline
\end{tabular}

Sumber : $\quad$ Hasil Perhitungan dari Peta Penggunaan Tanah Kota Bengkulu, Skala 1 : 25.000, Tahun 2012

Tabel di atas menunjukkan bahwa pada tahun 2012 penggunaan tanah Kota Bengkulu terbesar berupa berupa Hutan Lebat $(64,23 \%)$ dan kebun sejenis $(20,21 \%)$. Hutan Lebat memiliki luas $107.351,72 \mathrm{Ha}$ sedangkan kebun sejenis seluas $33.785,75 \mathrm{Ha}$. Jika dibandingkan dengan Tahun 2007 Hutan Lebat di Kota Bengkulu mengalami pengurangan luas yang diakibatkan banyaknya pembukaan tanah yang diusahakan oleh masyarakat (budidaya pertanian).

\subsubsection{Penguasaan tanah}

Berdasarkan data yang diperoleh dari Kantor Pertanahan Kota Bengkulu, Gambaran umum penguasaan tanah di Kota Bengkulu dapat dilihat pada Tabel 5 di bawah ini. 
Tabel 30. Gambaran Umum Penguasaan Tanah Kota Bengkulu

\begin{tabular}{|c|l|r|r|}
\hline No & Gambaran Umum Penguasaan Tanah & Luas (Ha) & \% Luas Wilayah \\
\hline 1 & PTSB Industri & 17,77 & 0,12 \\
2 & Tanah Hak UUPA, dan Perorangan & $12.622,12$ & 82,54 \\
3 & Tanah Negara Lainnya & 1,52 & 0,01 \\
4 & Hutan Suaka Alam dan Hutan Wisata & $1.526,97$ & 9,98 \\
5 & Perairan TOTAL & $1.124,51$ & 7,35 \\
\hline \multicolumn{2}{|c|}{ TOn } \\
Sumber: & Hasil Perhitungan dari Peta Gambaran Umum Penguasaan Tanah Kota Bengkulu, Skala 1: \\
& 25.000, Tahun 2012
\end{tabular}

Sebagian besar wilayah Kota Bengkulu berupa Tanah Hak UUPA, dan Perorangan seluas 12.622,12 Ha atau 82,54\% dari total luas Kota Bengkulu. Diurutan terluas kedua berupa Hutan Suaka Alam dan Hutan Wisata dengan luas 1.526,97 Ha atau 9,98\% dari luas wilayah Kota Bengkulu, Perairan memiliki luas 1.124,51 Ha (7,35\%), PTSB Industri memiliki luas 17,77 $\mathrm{Ha}$ atau $0,12 \%$ dari luas total Kota Bengkulu dan Tanah Negara Lainnya seluas 1,52 $\mathrm{Ha}$.

Berdasarkan tabeldi atas menunjukkan bahwa 9,98\% wilayah Kota Bengkulu merupakan Kawasan Konservasi (Kawasan Hutan) yang perlu mendapat perhatian khusus terkait kebijakan yang diambil Pemerintah Daerah setempat mengingat dengan tingginya alih fungsi lahan menjadi tanah budidaya non pertanian mengingat kebutuhan akan tanah akan semakin besar, dan cenderung untuk memanfaatkan tanah non budidaya.

Jika dilihat dari Gambaran Umum Penguasaan Tanah perkecamatan klasifikasi berupa Tanah Hak UUPA, dan Perorangan sebagian besar terdapat di Kecamatan Selebar (3.908,58 $\mathrm{Ha})$, Kecamatan Kampung Melayu $(2.915,33 \mathrm{Ha})$ dan Kecamatan Muara Bangkahulu seluas 2.253,09 Ha. Kawasan Hutan Suaka Alam dan Hutan Wisata terdapat di seluruh (sembilan) Kecamatan di Kota Bengkulu. Kecamatan yang memiliki Kawasan Hutan Suaka Alam dan Hutan Wisata terluas terdapat di Kecamatan Kampung Melayu seluas 600,81 Ha, Penguasaan Tanah Hak-hak UUPA dan Perorangan terluas terdapat di Kecamatan Selebar dengan luas 3.908,58 Ha, PTSB Industri hanya terdapat di Kecamatan Kampung Melayu (16,09 Ha) dan Kecamatan Sungai Serut $(1,68 \mathrm{Ha})$.

\subsection{Kabupaten Bengkulu Utara}

Kabupaten Bengkulu Utara termasuk dalam wilayah Propinsi Bengkulu yang telah berdiri sejak provinsi Bengkulu masih bagian dari Provinsi Sumatera Selatan (Undang-Undang Darurat No. 4 Tahun 1956 menyatakan Bengkulu Utara sebagai salah satu Kabupaten dalam Provinsi Sumatera Selatan dengan Ibu Kota di Kotamadya Bengkulu). Setelah terbentuknya Provinsi Bengkulu, Kabupaten Bengkulu Utara merupakan bagian dari Provinsi Bengkulu melalui Undang-Undang No.9 Tahun 1967 (Undang-Undang Pembentukan Propinsi Bengkulu). Sejak tahun 1976 Ibu kota Kabupaten Bengkulu Utara pindah dari Kota Bengkulu ke Kota Arga Makmur (melalui PP. No. 23 Tahun 1976). Pasca era Reformasi Berdasarkan Undang-Undang Republik Indonesia No. 23 Tahun 2003 Kabupaten Bengkulu Utara dimekarkan menjadi 
Kabupaten Mukomuko dan Kabupaten Bengkulu Utara dan berdasarkan Undang-undang Nomor 24 Tahun 2008 Bengkulu Utara dimekarkan kembali menjadi Bengkulu Utara dan Bengkulu Tengah.

\subsubsection{Kondisi Fisik Wilayah}

Secara geografis Kabupaten Bengkulu Utara terletak pada 101032' - 10208' BT dan pada $2^{0} 15^{\prime}-4^{0}$ LS. Batas-batas wilayah Kabupaten Bengkulu Utara adalah:
a. Sebelah Utara
: Kabupaten Mukomuko
b. Sebelah Timur
:Provinsi Jambi, Kabupaten Lebong dan Kabupaten Kepahiang
c. Sebelah Selatan : Kabupaten Bengkulu Tengah
d. Sebelah Barat : Samudera Hindia.

Berdasarkan Bengkulu Utara dalam Angka Tahun 2010, Luas wilayah Kabupaten Bengkulu Utara adalah 4.424,60 $\mathrm{km}^{2}$. Kabupaten Bengkulu Utara secara administratif terbagi menjadi 12 (duabelas) kecamatan yaitu Kecamatan Air Besi, Kecamatan Air Napal, Kecamatan Argamakmur, Kecamatan Batiknau, Kecamatan Enggano, Kecamatan Girimulya, Kecamatan Kerkap, Kecamatan Ketahun, Kecamatan Lais, Kecamatan Napal Putih, Kecamatan Padang Jaya dan Kecamatan Putri Hijau. Untuk lebih lengkapnya dapat dilihat pada Tabel 1.

Kondisi geografisnya sebagian besar merupakan dataran dengan ketinggian di bawah $150 \mathrm{~m}$ dpl terdapat dibagian barat membujur searah pantai dari selatan ke timur, sedangkan dibagian timur topografinya berbukit-bukit dengan ketinggian $541 \mathrm{~m}$ dpl.

Tabel 31. Luas dan Jumlah Penduduk Kabupaten Bengkulu Utara

\begin{tabular}{|c|l|r|r|r|r|r|}
\hline \multirow{2}{*}{ No Kecamatan } & \multicolumn{2}{|c|}{ Luas } & \multicolumn{2}{c|}{$\begin{array}{c}\text { Jumlah } \\
\text { Penduduk }\end{array}$} & $\begin{array}{c}\text { Kepadatan } \\
\text { Penduduk }\end{array}$ \\
\cline { 3 - 7 } & & \multicolumn{1}{c|}{ Ha } & \multicolumn{1}{c}{$\%$} & \multicolumn{1}{c|}{ Jiwa } & \multicolumn{1}{c|}{$\%$} & Jiwa/Km ${ }^{2}$ \\
\hline 1 & Air Besi & $8.999,82$ & 1,98 & 9.908 & 3,92 & 110 \\
2 & Air Napal & $7.455,80$ & 1,64 & 10.521 & 4,16 & 141 \\
3 & Arga Makmur & $12.882,38$ & 2,84 & 44.772 & 17,69 & 348 \\
4 & Batiknau & $15.509,89$ & 3,42 & 10.322 & 4,08 & 67 \\
5 & Enggano & $39.611,55$ & 8,74 & 2.322 & 0,92 & 6 \\
6 & Girimulya & $23.144,65$ & 5,10 & 13.798 & 5,45 & 60 \\
7 & Kerkap & $40.746,25$ & 8,99 & 23.245 & 9,19 & 57 \\
8 & Ketahun & $88.589,87$ & 19,54 & 38.217 & 15,10 & 43 \\
9 & Lais & $17.146,84$ & 3,78 & 16.752 & 6,62 & 98 \\
10 & Napal Putih & $84.902,95$ & 18,72 & 16.325 & 6,45 & 19 \\
11 & Padang Jaya & $24.017,62$ & 5,30 & 26.074 & 10,30 & 109 \\
12 & Putri Hijau & $86.274,54$ & 19,03 & 40.796 & 16,12 & 47 \\
13 & Sungai/Danau/Situ/Telaga & $4.153,24$ & 0,92 & - & - & - \\
\hline & Total & $453.435,40$ & 100,00 & 253.052 & 100,00 & 56 \\
\hline
\end{tabular}

Sumber: Perhitungan luas administrasi, Badan Pertanahan Nasional RI (2011) dan Kabupaten Bengkulu Utara Dalam Angka Tahun 2010 
Tabel di atas menunjukkan luas Kabupaten Bengkulu Utara adalah 453.435,40 Ha (BPN $\mathrm{RI}$ 2011). Kecamatan yang terluas adalah Kecamatan Ketahun dengan luas $88.589,87 \mathrm{Ha}$ atau $19,54 \%$ dari luas Kabupaten Bengkulu Utara. Sedangkan kecamatan yang luasannya paling kecil yaitu Kecamatan Air Napal dengan luas 7.455,80 Ha atau 1,64\%. Sebaran lokasi Kecamatan dapat dilihat pada Peta Administrasi Kabupaten Bengkulu Utara (Peta 1).

\subsubsection{Kondisi Sosial Ekonomi Wilayah}

Pertanian merupakan sektor yang penting, karena memiliki peran yang besar terhadap pertumbuhan ekonomi Kabupaten Bengkulu Utara.Hal tersebut dapat dilihat dari besarnya kontribusi sektor pertanian terhadap peningkatan PDRB Kabupaten Bengkulu Utara, terutama sub sektor tanaman bahan makanan, yaitu padi dan palawija.

Nilai nominal PDRB sektor pertanian atas dasar harga berlaku pada tahun 2015 sebesar Rp 2.371.848,00 juta dan peranannya dalam PDRB Kabupaten Bengkulu Utara sebesar 41,35 $\%$. Kemudian diikuti sektor pertambangan dan penggalian dengan nominal atas dasar harga berlaku pada tahun 2015 sebesar Rp 622.664,4 juta dengan peran sebesar 10,86 \%. Produksi terbesar batubara se-Provinsi Bengkulu adalah Kabupaten Bengkulu Utara, sehingga Kabupaten Bengkulu Utara juga merupakan kontributor terbesar pada lapangan usaha pertambangan dan penggalian PDRB Provinsi Bengkulu.Selain pertambangan Batubara, terdapat pertambangan dan penggalian lainnya, seperti batu, pasir dan lain-lain. Pada Tahun 2014, lapangan usaha industri pengolahan memberikan kontribusi sebesar 8,58 persen sedangkan pada Tahun 2013 sebesar 8,36 persen. Industri yang memberikan kontribusi terbesar adalah industri makanan dan minuman.Di kabupaten Bengkulu Utara, industri makanan dan minuman terbesar adalah industri CPO yang berada dibeberapa kecamatan di Kabupaten Bengkulu Utara.

\subsubsection{Penggunaan Tanah}

Penggunaan tanah Kabupaten Bengkulu Utara pada tahun 2011 terbesar berupa berupa Hutan Lebat $(38,74 \%)$ dan perkebunan rakyat $(29,89 \%)$. Hutan Lebat memiliki luas $175.683,23$ Ha sedangkan perkebunan rakyat seluas $135.510,91 \mathrm{Ha}$. Jika dibandingkan dengan Tahun 2006 Hutan Lebat di Kabupaten Bengkulu Utara mengalami pengurangan luas yang diakibatkan banyaknya pembukaan tanah yang diusahakan oleh masyarakat (budidaya pertanian). Tanah yang sudah diusahakan penduduk berupa perkebunan rakyat seluas 135.510,91 $\mathrm{Ha}$ atau 29,89\%; perkebunan besar seluas 59.945,61 $\mathrm{Ha}$ atau 13,22\%; kebun campuran seluas $18.200,76 \mathrm{Ha}(4,01 \%)$, sawah irigasi 2xpadi/th seluas $4.827,86 \mathrm{Ha}$ atau 1,06\%; tegalan/ladang seluas $11.336,60(2,50 \%)$ serta kampung seluas $11.947,62 \mathrm{Ha}$ atau 2,63\%. Jika dilihat penggunaan tanah perkecamatan untuk Tahun 2011 hampir di 90\% Kecamatan di Kabupaten Bengkulu Utara terjadi alih fungsi lahan dari penggunaan tanah berupa hutan belukar dan hutan lebat ke perkebunan rakyat. Alih fungsi lahan dari hutan belukar menjadi lahan perkebunan rakyat terluas terjadi di Kecamatan Kerkap yaitu dari 5.857,79 Ha hutan belukar beralih fungsi $1.369,14$ Ha menjadi lahan perkebunan rakyat. 
Tabel 32. Penggunaan Tanah Kabupaten Bengkulu Utara Tahun 2011

\begin{tabular}{|c|l|r|r|}
\hline No & Penggunaan Tanah & Luas (Ha) & \multicolumn{2}{|c|}{ Wilayah } \\
\hline 1 & Emplasemen & 1,29 & 0,00 \\
2 & Hutan Belukar & $23.822,64$ & 5,25 \\
3 & Hutan Lebat & $175.683,23$ & 38,74 \\
4 & Hutan Sejenis & $1.533,52$ & 0,34 \\
5 & Kampung & $11.947,62$ & 2,63 \\
6 & Kebun Campuran & $18.200,76$ & 4,01 \\
7 & Padang rumput/sabana & 422,08 & 0,09 \\
8 & Perkebunan Besar & $59.945,61$ & 13,22 \\
9 & Perkebunan Rakyat & $135.510,91$ & 29,89 \\
10 & Pertambangan & 65,33 & 0,01 \\
11 & Rawa & 878,72 & 0,19 \\
12 & Sawah Irigasi 1xpadi/Th & 711,43 & 0,16 \\
14 & Sawah Irigasi 2xpadi/Th & $4.827,86$ & 1,06 \\
15 & Sawah Tadah Hujan & 73,99 & 0,02 \\
16 & Semak & $3.823,00$ & 0,84 \\
17 & Tambak & 335,33 & 0,07 \\
18 & Tanah Rusak & 12,40 & 0,00 \\
19 & Tanah Terbuka Sementara & 149,82 & 0,03 \\
20 & Tegalan/Ladang & $11.336,60$ & 2,50 \\
21 & Sungai/Danau/Situ/Telaga & $4.153,24$ & 0,92 \\
\hline & & Total & 100,00 \\
\hline
\end{tabular}

Sumber: Hasil Perhitungan dari Peta Penggunaan Tanah Kabupaten Bengkulu Utara, Skala 1 : 50.000, Tahun 2011

\subsubsection{Penguasaan Tanah}

Berdasarkan data yang diperoleh dari Kantor Pertanahan Kabupaten Bengkulu Utara, Gambaran umum penguasaan tanah di Kabupaten Bengkulu Utara dapat dilihat pada Tabel di bawah ini.

Tabel 33. Penguasaan Tanah Kabupaten Bengkulu Utara Tahun 2011

\begin{tabular}{|c|l|r|r|}
\hline No & Gambaran Umum Penguasaan Tanah & Luas (Ha) & \multicolumn{1}{c|}{$\begin{array}{c}\text { \% Luas } \\
\text { Wilayah }\end{array}$} \\
\hline 1 & Hutan Lindung & $16.461,08$ & 3,630 \\
2 & Hutan Produksi & $18.693,31$ & 4,123 \\
3 & Hutan Produksi Terbatas & $47.787,58$ & 10,539 \\
4 & Hutan Suaka Alam dan Hutan Wisata & 14,74 & 0,003 \\
5 & PTSB Industri & 49,07 & 0,011 \\
6 & PTSB Perkebunan & $57.453,34$ & 12,671 \\
7 & Taman Nasional & $71.628,64$ & 15,797
\end{tabular}




\begin{tabular}{|c|l|r|r|}
8 & Tanah Hak UUPA Badan Hukum dan Perorangan & $196.699,50$ & 43,380 \\
9 & Tanah Negara Lainnya & $40.494,90$ & 8,931 \\
10 & Sungai/Danau/Situ/Telaga & $4.153,24$ & 0,916 \\
\hline Total & $453.435,40$ & 100 \\
\hline
\end{tabular}

Sumber: Hasil Perhitungan dari Peta Gambaran Umum Penguasaan Tanah Kabupaten Bengkulu Utara, Skala 1 : 50.000, Tahun 2011

Sebagian besar wilayah Kabupaten Bengkulu Utara berupa Tanah Hak UUPA, Badan Hukum dan Perorangan dengan luas 196.699,50 Ha atau 43,38\% dari luas wilayah Kabupaten Bengkulu Utara, Taman Nasional memiliki luas 71.628,64 Ha (15,80\%), PTSB Perkebunan memiliki luas 57.453,34\% (12,67\%), Hutan Produksi Terbatas memiliki luas 47.787,58 Ha (10,54\%) dan Tanah Negara Lainnya seluas $40.494,90$ Ha (8,93\%) sisanya adalah, Hutan Produksi 18.693,31 Ha, Hutan Lindung 16.461,08 Ha, PTSB Industri 49,07 Ha, Hutan Suaka Alam dan Hutan Wisata 14,74 Ha dan sungai/danau/situ/telaga 4.153,24 Ha (0,92\%) .

Berdasarkan tabel di atas menunjukkan bahwa Kabupaten Bengkulu Utara memiliki Kawasan Hutan yang cukup luas yang perlu mendapat perhatian dari Pemerintah Daerah dan Dinas Kehutanan mengingat dengan bertambahnya penduduk kebutuhan akan tanah akan semakin besar, dan cenderung untuk memanfaatkan tanah yang masih belum dikuasai oleh orang atau badan hukum. 


\section{BAB V \\ HASIL PENGUMPULAN DATA DAN PEMBAHASAN}

\subsection{Lokasi Tanah Timbul}

Dari lima provinsi sampel, diperoleh tiga belas kabupaten/kota yang diindikasikan terdapat lokasi tanah timbul. Indikasi lokasi tanah timbul berdasarkan informasi data Direktorat WP3WT, dan beberapa nara sumber. Setelah melakukan pengumpulan data lapang, ada beberapa lokasi yang perlu dipertimbangkan apakah dapat disebut sebagai tanah timbul, walaupun memenuhi ketentuan perundangan untuk disebut sebagai tanah timbul.

Tipologi lokasi tanah timbul yang ditemukan berada di pesisir pantai, muara dan sungai, bahkan ada yang di tengah sungai.

\subsubsection{Kabupaten Cilacap}

Tanah timbul di Kabupaten Cilacap terbentuk akibat proses sedimentasi lumpur di Laguna Segara Anakan. Kawasan Segara Anakan berlokasi di perbatasan Kabupaten Ciamis Provinsi Jawa Barat dengan Kabupaten Cilacap Provinsi Jawa Tengah. Segara Anakan merupakan laguna raksasa yang secara geografis terletak pada koordinat $7^{\circ} 35^{\prime}$ LS sampai $7^{\circ} 50^{\prime}$ LS dan $108^{\circ} 45^{\prime}$ BT sampai $109^{\circ} 45^{\prime}$ BT dan secara administratif masuk ke dalam wilayah Kecamatan Kampung laut.

Kawasan Segara Anakan merupakan tempat bertemunya 3 (tiga) sungai besar, yaitu Sungai Citanduy, Sungai Cibereum dan Sungai Cikonde serta sungai-sungai kecil lainnya. Kawasan ini juga menjadi penghubung pergerakan ekonomi dan sarana transportasi air masyarakat dari Cilacap menuju Pangandaran.

Laguna sendiri dalam istilah geografi adalah perairan yang hampir seluruh wilayahnya dikelilingi daratan dan hanya menyisakan sedikit celah yang berhubungan dengan laut. Segara Anakan merupakan kawasan perairan yang unik, karena didominasi hamparan hutan bakau (mangrove) yang sangat luas.

Laguna Segara Anakan secara berkesinambungan mengalami degradasi akibat tingkat pengendapan yang tinggi. Adanya pengendapan pada perairan tersebut telah mengakibatkan terjadinya pendangkalan serta penyempitan luasan. Luas perairan Laguna Segara Anakan tahun 1903 masih 6.450 ha. Namun tahun 1939, tinggal 6.060 ha. Jadi, dalam kurun waktu 36 tahun luas wilayah perairan laguna yang hilang akibat sedimentasi mencapai 390 ha. Sekitar tahun 1971, luas Segara Anakan menyusut lagi menjadi 4.290 ha. Hal ini terus berlanjut hingga pada tahun 1984, luas laguna yang memiliki hutan mangrove terluas di Jawa itu hanya 2.906 ha. Jumlah itu, pada tahun 1994, atau 10 tahun kemudian, menyusut dari 1.331 ha menjadi 1.575 ha. Penyusutan kembali terjadi tahun 2005, atau 11 tahun kemudian, menjadi 834 ha. Artinya, dalam kurun waktu 21 tahun, terjadi penyusutan luasan laguna 2.072 ha atau 98,6 ha per tahun.

Penumpukan sedimen terutama terjadi pada daerah utara laguna. Hal tersebut dimungkinkan karena bagian selatan laguna ialah bagian cekungan yang tidak memiliki arus 
deras. Sedangkan pada bagian selatan, yang mendekati Pulau Nusakambangan merupakan kawasan yang berarus deras.

Perkembangan pengurangan luas kawasan laguna padatahun 1998 - 2003 hanya mengalami pengurangan luas sekitar $60 \mathrm{Ha}$ /tahun. Terdapat indikasi telah terjadi perbaikan kondisi 3 kali lebih baik dari 20 tahun sebelumnya, meskipun pengurangan luas $60 \mathrm{Ha}$ per tahun masih tidak dapat dihindari.

Kerusakan laguna Segara Anakan terutama disebabkan tingginya materi sedimen yang masuk ke dalamnya. Diperkirakan besarnya sedimen yang masuk dari sungai Citanduy sebesar 8.05 juta ton/tahun, sungai Cimeneng sebesar 0.87 juta ton /tahun dan sungai Cikonde 0,22 juta ton/tahun, dengan total pasokan sedimen 9.14 juta ton/tahun. Dan total sedimen yang masuk ke Segara Anakan sekitar 8,5 juta ton/tahun keluar ke laut dan sekitar 0,66 juta ton/tahun mengendap di laguna Segara Anakan. ${ }^{25}$

Laju sedimentasi yang tinggi dari tahun ke tahun menyebabkan luasan laguna Segara Anakan semakin menyusut. Walaupun terdapat perbedaan data dari berbagai sumber yang berbeda, namun data-data tersebut menunjukkan kecenderungan yang sama dalam menggambarkan laju penurunan luasan laguna Segara Anakan. Laju sedimentasi yang tinggi di laguna Segara Anakan juga mengakibatkan menyempitnya alur (celah) di Plawangan Barat yang menghubungkan laguna dan laut lepas Samudera Hindia hingga berjarak sekitar $60 \mathrm{~m}$ antara pulau Jawa dan Nusakambangan dari sebelumnya berjarak 300 m pada tahun 2002. Kedalamannya pun menjadi semakin dangkal, mulai dari minus 0,63 m sampai 4,6 $\mathrm{m}$. Celah tersebut sangat penting untuk mengalirkan air sungai dan sedimen ke laut, sirkulasi air laut dan air tawar di laguna, serta menjadi pintu gerbang masuk dan keluarnya biota laut pada saat pemijahan, mencari makan, dan membesarkan diri. ${ }^{26}$ Adanya proses sedimentasi di Segara Anakan yang cukup tinggi membentuk tanah timbul yang kemudian dikenal sebagai kampung laut.

Tanah-tanah timbul terdapat pada semua desa di wilayah di Kecamatan Kampung Laut yaitu: Desa Klaces, Ujung Alang, Panikel dan Ujung Gagak. Desa Klaces dan Ujung Alang lokasinya menempel dengan Pulau Nusa Kambangan, sementara Desa Panikel dan Ujung Gagak letaknya di Pulau Jawa. Luas Wilayah Kecamatan kampung Laut adalah 144,2621 km2 atau 6,08\% dari luas Kabupaten Cilacap.

Keberadaan tanah timbul di Kawasan Segara Anakan ini sangat berpengaruh pada proses pembentukan Kecamatan Kampung Laut. Sebelum terbentuknya Kecamatan Kampung Laut, pada awalnya tiga desa, Panikel, Ujung Alang dan Ujung Gagak, masih termasuk ke dalam wilayah Kecamatan Patimunan. Keberadaan tanah timbul di wilayah ini menjadi daya tarik yang kuat bagi masyarakat untuk datang dan mulai mengokupasinya. Seiring waktu jumlah masyarakat yang datang semakin banyak dan mulai menetap pada tanah timbul yang ada terutama di wilayah Desa Ujung Alang. Pertambahan penduduk pada tiga desa tersebut

\footnotetext{
${ }^{25}$ https://id.wikipedia.org/wiki/Segara_Anakan

${ }^{26}$ Yuliarko Sukardi, Permasalahan Kawasan Segara Anakan, Jurnal Perencanaan Pembangunan edisi 2, 2010
} 
memunculkan wacana untuk membentuk wilayah kecamatan administratif yang baru. Untuk memenuhi persyaratan pengembangan wilayah kecamatan baru yang mensyaratkan minimal terdapat empat desa, maka Desa Ujung Alang dipecah menjadi dua menjadi Desa Ujung Alang dan Klaces. Pada tahun 2012 Kecamatan Kampung Laut resmi secara definitif berdiri dengan ibukotanya di Klaces.

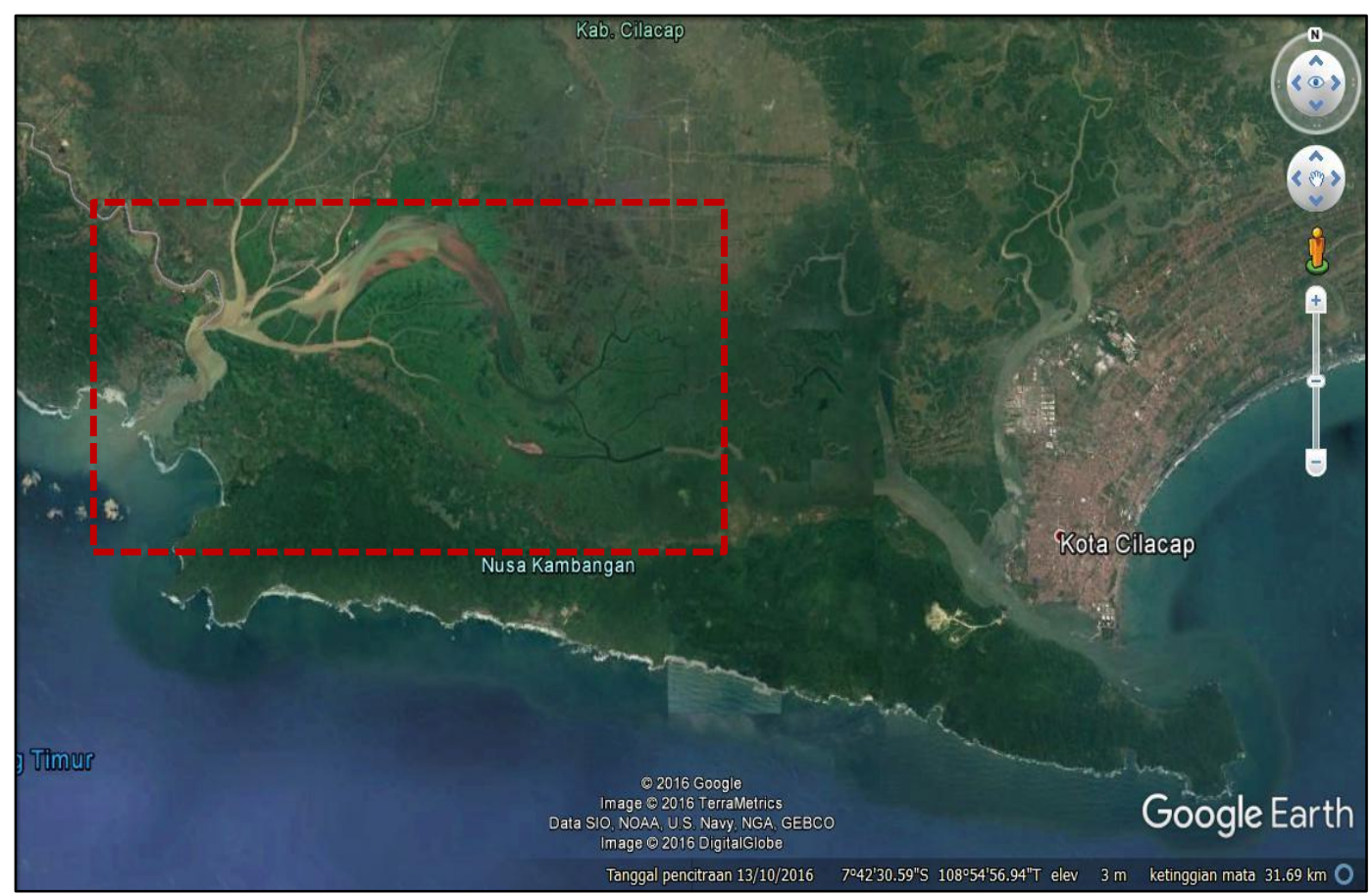

(Sumber : Google Earth)

Gambar 14. Kawasan Segara Anakan dan sekitarnya

Hasil overlay data sungai dan perairan di wilayah Kecamatan Kampung Laut dari Neraca Penatagunaan Tanah (2013) dengan Peta Army Map Service (1954) pada gambar dibawah ini cukup memberikan gambaran mengenai penambahan daratan (tanah timbul) yang terjadi di Laguna Segara Anakan dalam kurun waktu selama hampir 60 tahun tersebut. Penyusutan wilayah perairan menjadi daratan dapat dilihat dari berkurangnya luasan warna biru tua (1954) menjadi warna biru muda (2013). Berdasarkan informasi Kantor Pertanahan Kabupaten Cilacap diperoleh data telah terjadi penambahan daratan sebesar $2.082 \mathrm{Ha}$. 


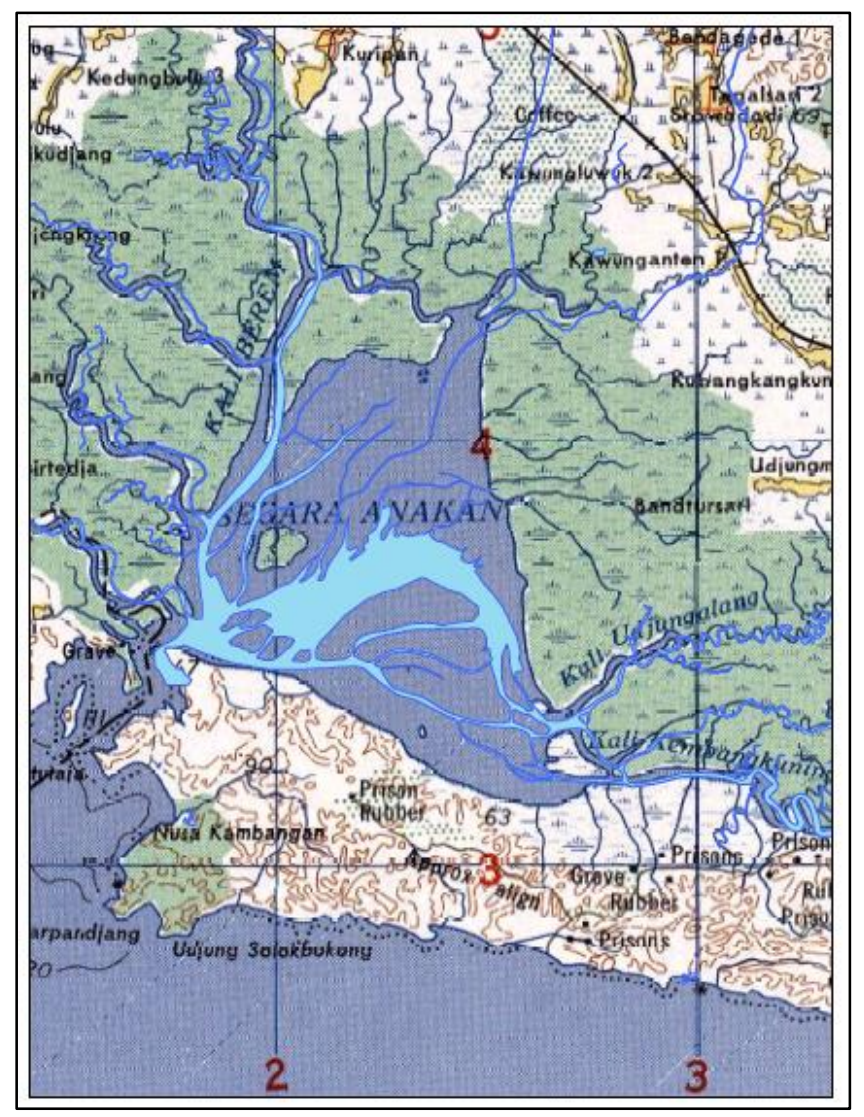

Gambar 15. Overlay kondisi perairan Segara Anakan tahun 1954 dan 2013

Berdasarkan Neraca Penatagunaan Tanah Kabupaten Cilacap tahun 2013 tutupan lahan terbesar di Kecamatan Kampung Laut berupa Hutan Rawa dan Lahan Pertanian sebesar masing masing kurang lebih 31 persen. Sedangkan luasan terkecil berupa Hutan sebesar 4,81 hektar atau 0,03 persen. Sebagian besar Hutan Rawa berada di sebelah timur laguna sedangkan pada bagian tengah didominasi Rawa-rawa.

Tabel 34. Penggunaan Tanah Kecamatan Kampung Laut

\begin{tabular}{clrr}
\hline No & Penggunaan Tanah & Luas_Ha & \multicolumn{1}{c}{$\%$} \\
\hline 1 & Hutan & 4,81 & 0,03 \\
\hline 2 & Hutan Rawa & 4525,48 & 31,43 \\
\hline 3 & Kampung & 278,99 & 1,94 \\
\hline 4 & Rawa & 3093,22 & 21,48 \\
\hline 5 & Rumput & 14,25 & 0,10 \\
6 & Sawah 2 X padi & 4535,13 & 31,49 \\
\hline 7 & Sungai & 1858,63 & 12,91 \\
8 & Tambak & 46,04 & 0,32 \\
\hline 9 & Tegalan & 43,69 & 0,30 \\
\hline Luas Total & $\mathbf{1 4 4 0 0 , 2 4}$ & $\mathbf{1 0 0}$ \\
\hline Sumber : Neraca Penatagunaan Tanah Kabupaten Cilacap 2013 (diolah).
\end{tabular}




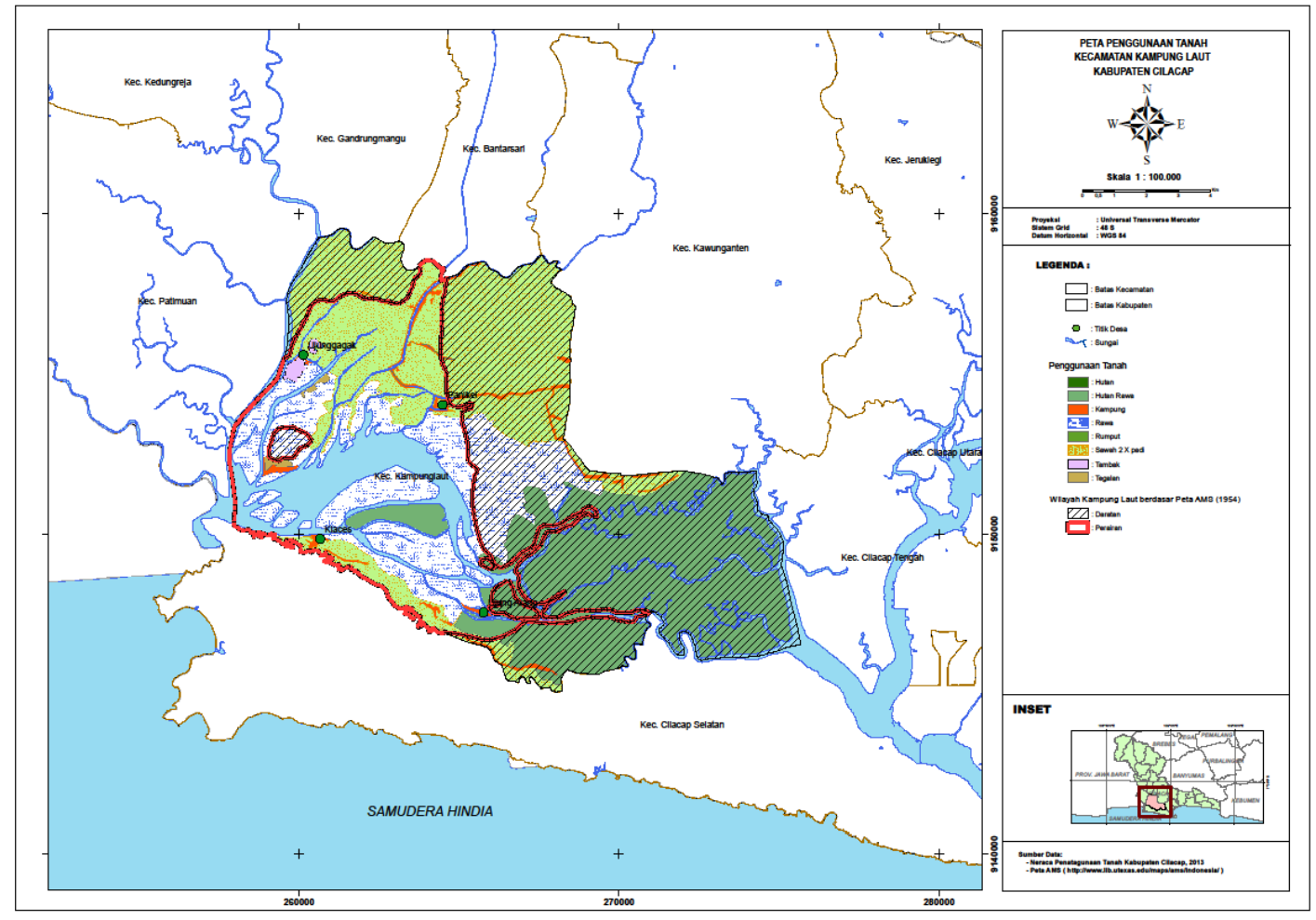

Sumber : Pengolahan data (Puslitbang, 2017).

Gambar 16. Peta Penggunaan Tanah Kecamatan Kampung Laut

Dengan mendeliniasi garis perairan pada peta AMS kemudian mengoverlay dengan Peta Penggunaan Tanah dari Neraca Penggunaan Tanah (Gambar 16) maka bisa dilihat tutupan lahan pada area tanah timbul. Berdasarkan gambar diatas, penggunaan tanah pada lokasi-lokasi yang diidentifikasi sebagai tanah timbul besar masih merupakan rawa-rawa. Tutupan lahan yang merupakan hasil budi daya manusia yang dominan terlihat berupa tanah pertanian yang dimanfaatkan sebagai sawah oleh masyarakat.Tanah timbul yang berkembang menjadi area pemukiman terdapat di dua desa yaitu Desa Klaces yang menjadi lbukota Kecamatan Kampung Laut dan Desa Ujung Alang. Penggunaan tanah yang lain berupa tambak-tambak bisa ditemukan di wilayah Desa Ujung Gagak.

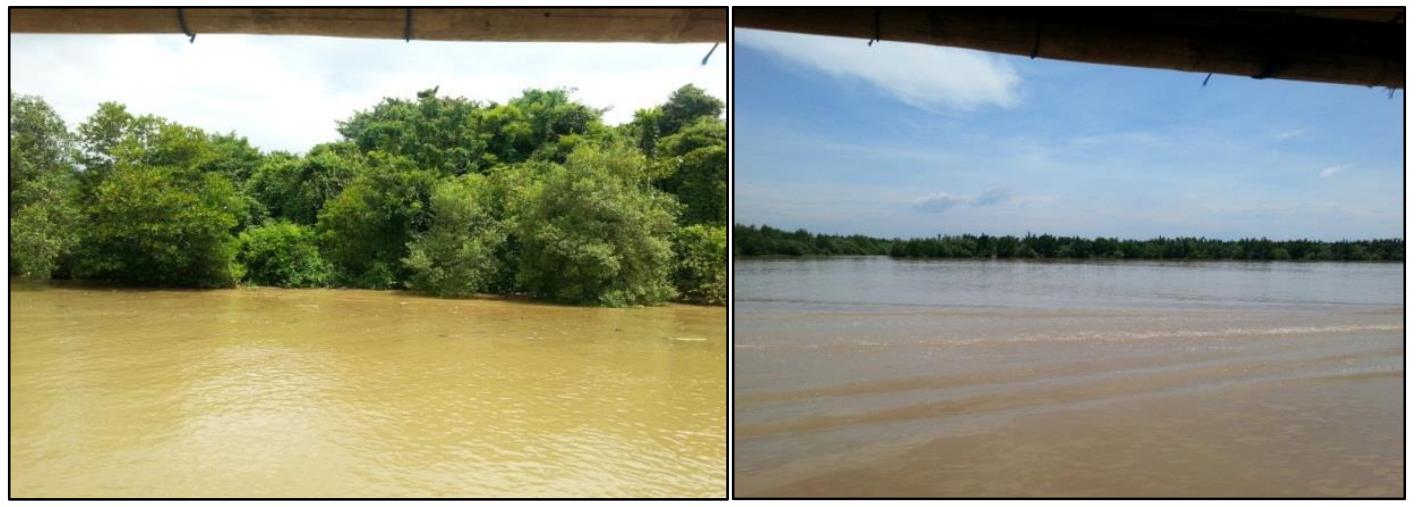

Gambar 17. Tanah timbul dengan tutupan lahan berupa hutan, tutupan rawa dan nipah(kanan) 

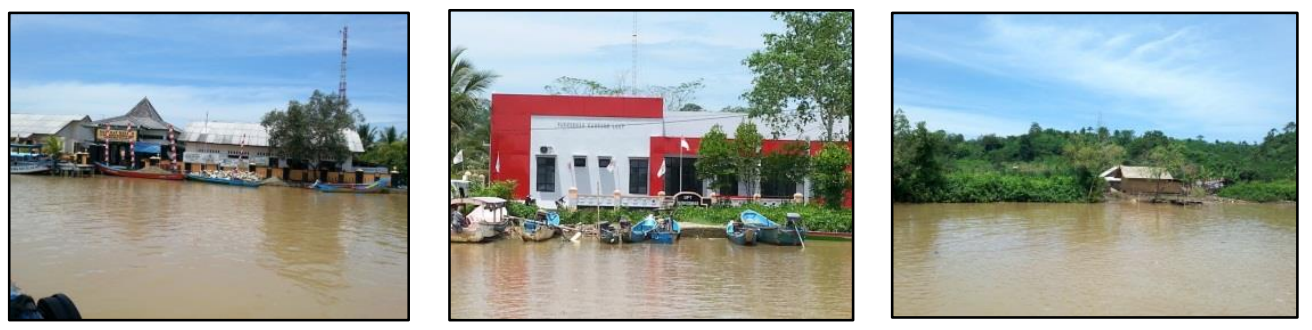

Gambar 18. Kantor Kecamatan Kampung Laut, Puskesmas dan rumah semi permanen di Klaces

\subsubsection{Lokasi Tanah Timbul di Kabupaten Kebumen}

Lokasi tanah timbul terletak di Desa Ayah, Kecamatan Ayah berdekatan dengan hutan mangrove yang sekarang menjadi alternatif tujuan wisata dan dikelola oleh Dinas Kehutanan. Berada di dekat muara Sungai Tanjung Bodo dengan Samudera Hindia, Tanah timbul terbentuk di kelokan sungai terbentuk akibat sedimentasi dari material-material yang terbawa aliran sungai.

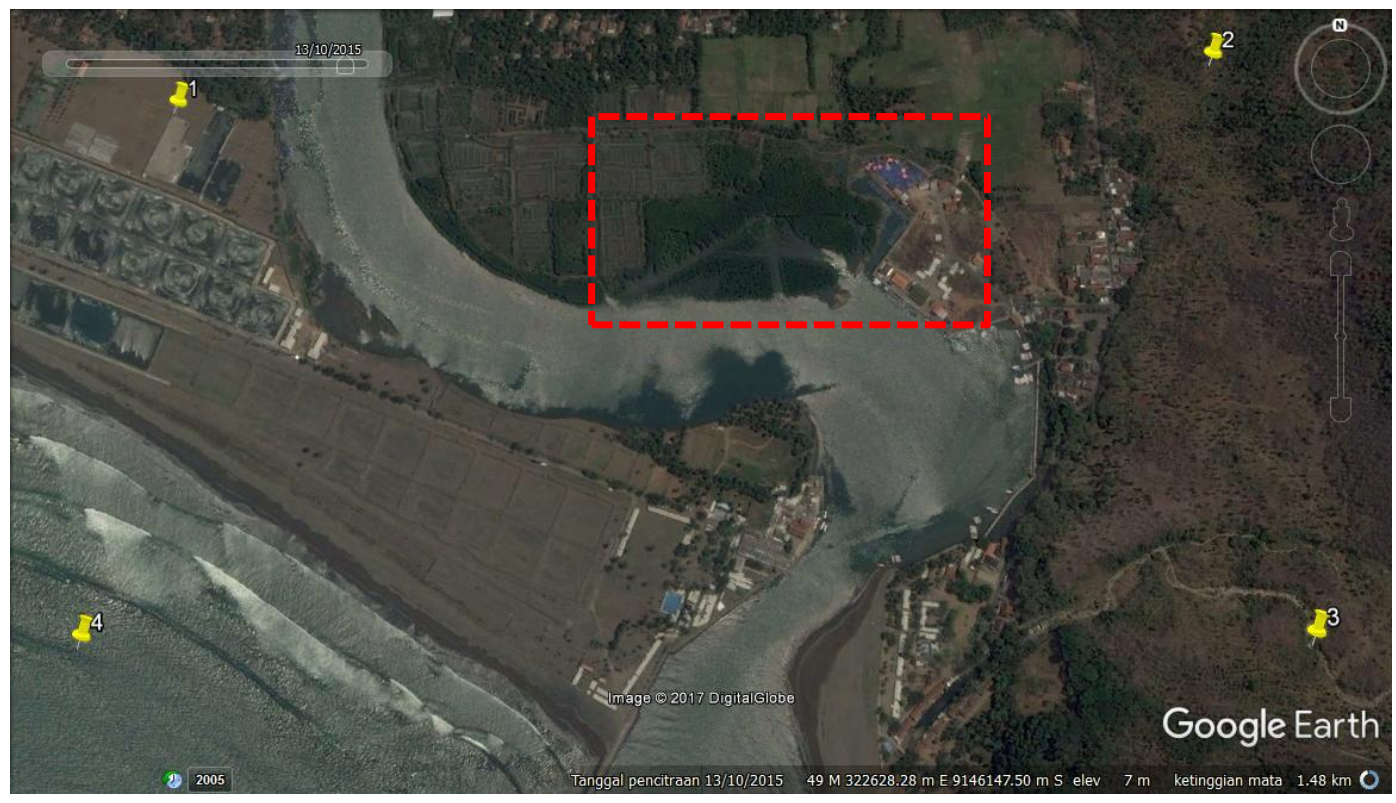

(Sumber : Google Earth)

Gambar 19. Lokasi tanah timbul di Kabupaten Kebumen

Berdasarkan data hasil inventarisasi Kantor Pertanahan Kabupaten Kebumen, lokasi tanah timbul yang dikuasai oleh masyarakat di desa Ayah Kecamatan Ayah, sebagian besar berada pada wilayah yang di tetapkan menjadi Kawasan Hutan Rakyat dan hanya sebagian kecil yang masuk dalam Kawasan Sempadan Sungai seperti terlihat pada gambar 19. Lebih lanjut, berdasarkan reklasifikasi dalam RTRW, Kawasan Sempadan Sungai adalah kawasan lindung sedang Kawasan Hutan Rakyat merupakan kawasan budidaya. Sehingga berdasarkan reklasifikasi tersebut maka bisa dikatakan bahwa tanah-tanah timbul yang dikuasai dan dimanfaatkan oleh masyarakat tersebut pada dasarnya berada pada kawasan yang diarahkan untuk kegiatan budidaya Hutan Rakyat. Hanya saja penggunaan tanah untuk areal pertanian 
dan tambak dikategorikan tidak sesuai untuk area yang diarahkan untuk Kawasan Hutan Rakyat.
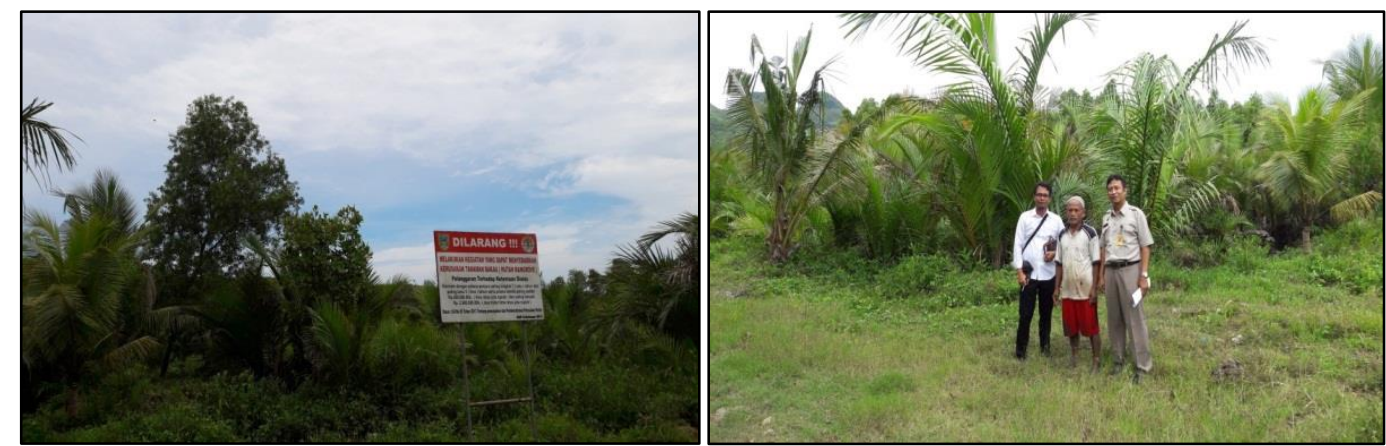

Gambar 20. Tanah Timbul berbatasan dengan kawasan mangrove dan foto penggarap

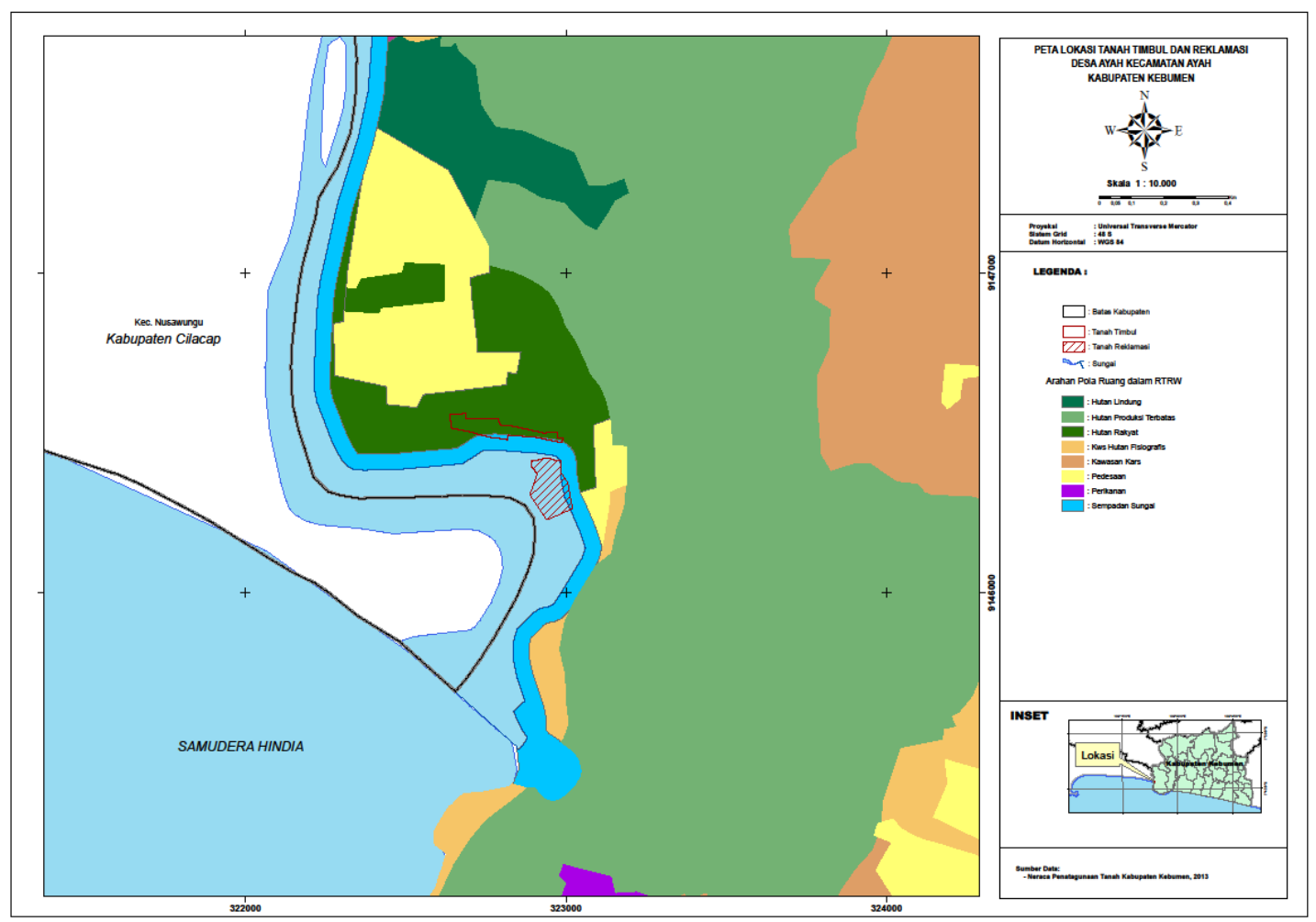

Sumber : Pengolahan data (Puslitbang, 2017)

Gambar 21. Lokasi Tanah Timbul dan Reklamasi di Kabupaten Kebumen di atas RTRW 


\subsubsection{Kabupaten Tulungagung}

Berdasarkan hasil koordinasi dengan Kantor Pertanahan dan Pemda Kabupaten Tulungagung, diperoleh informasi bahwa terdapat indikasi tanah timbul yang berada di delapan lokasi di daerah pantai selatan. Berikut ke delapan lokasi indikasi tanah timbul tersebut :

Tabel 35. Lokasi Tanah Timbul di Kab. Tulungagung

\begin{tabular}{|c|l|l|l|}
\hline NO & \multicolumn{1}{|c|}{ Nama Pantai } & \multicolumn{1}{c|}{ Desa } & \multicolumn{1}{c|}{ Kecamatan } \\
\hline 1 & Pantai Sane & Kalibatur & Kalidawir \\
\hline 2 & Pantai Dlodo & Pucanglaban & Pucanglaban \\
\hline 3 & Pantai Gerangan & Tanggunggunung & Tanggunggunung \\
\hline 4 & Pantai Brumbun & Ngrejo & Tanggunggunung \\
\hline 5 & Pantai Sidem & Sidem & Besuki \\
\hline 6 & Pantai bayem & Keboireng & Besuki \\
\hline 7 & Pantai Gemah & Keboireng & Besuki \\
\hline 8 & Pantai Nglarap & Keboireng & Besuki \\
\hline
\end{tabular}

Sumber : Pemda Kabupaten Tulungagung

Pengamatan lapangan pada beberapa lokasi, secara fisik pada area yang disebut sebagai tanah timbul terlihat sebagaimana pantai biasa pada umumnya dengan tidak menunjukan ciri-ciri tanah timbul. Klaim sebagai "tanah timbul" sendiri datang dari Pemerintah Daerah Kabupaten Tulungagung dengan mendeliniasi area ditepi pantai tersebut. Selanjutnya pihak Pemda bermaksud mengajukan Hak Pengelolaan untuk area tersebut, terutama di lokasi Pantai Gemah dan sekitarnya, karena memiliki potensi pariwisata yang bagus.

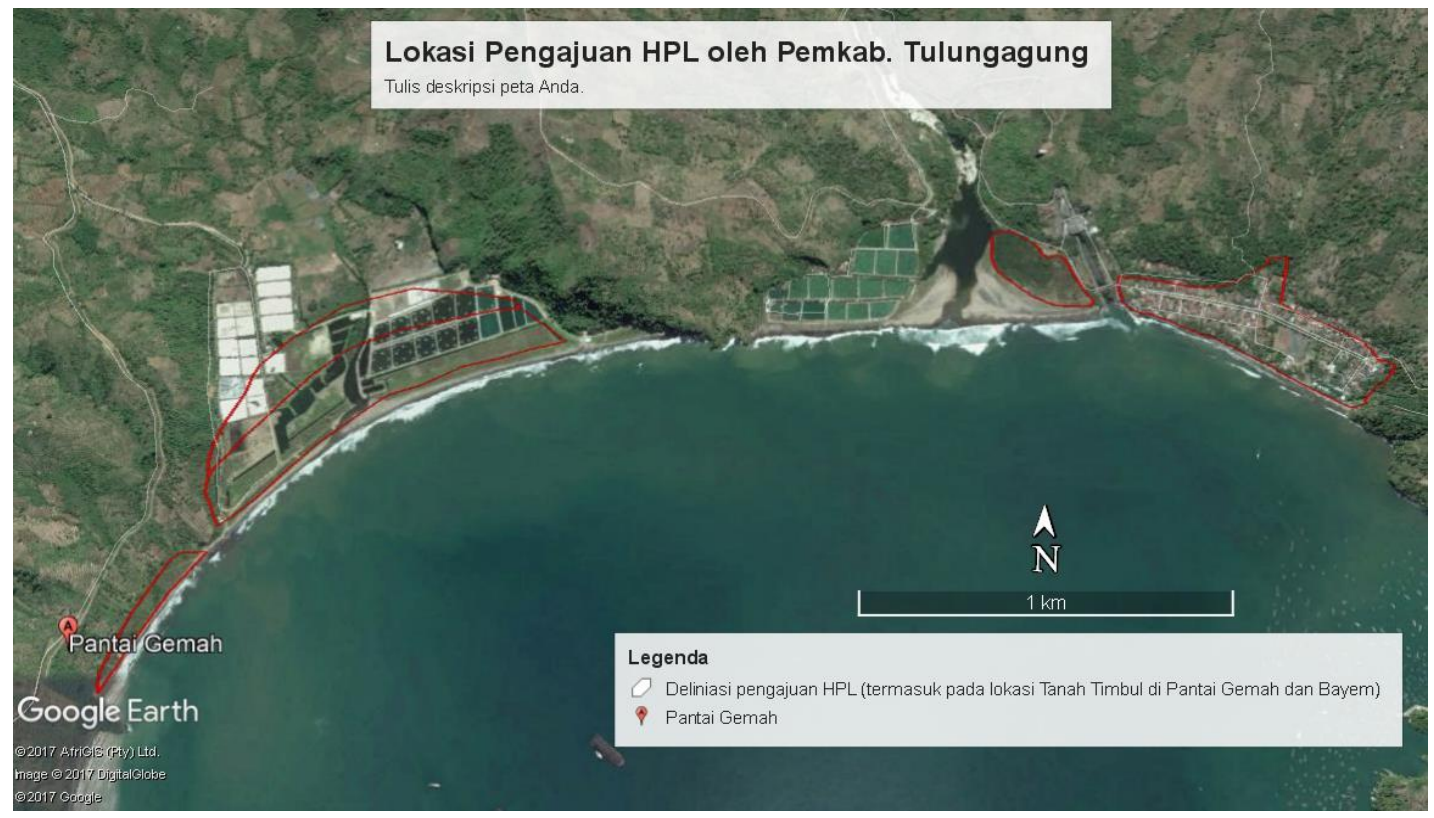

sumber : Google Earth (diolah)

Gambar 22. Lokasi tanah timbul dan pengajuan HPL oleh Pemda Tulungagung 

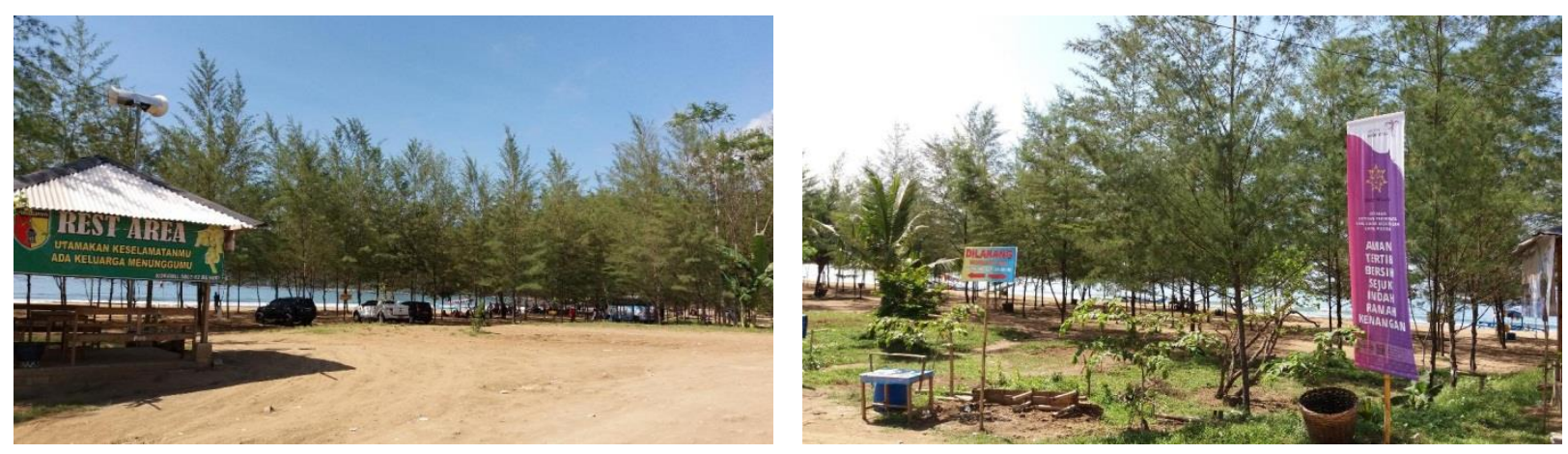

Sumber : Dokumen Penelitian

Gambar 23. Pantai Gemah
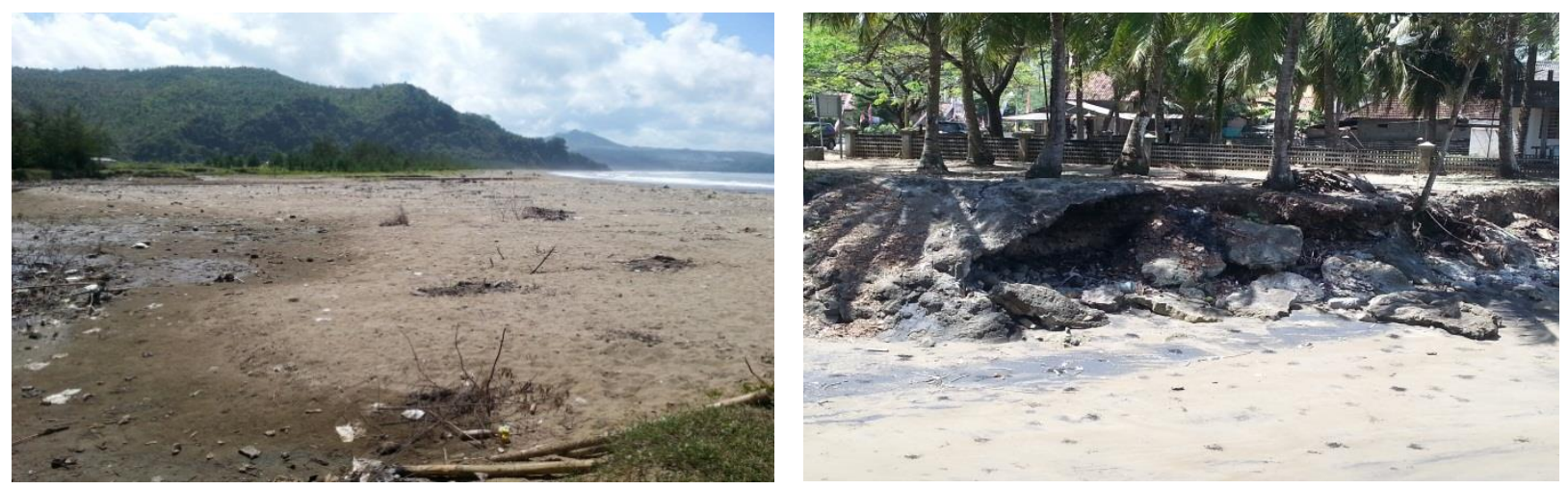

Sumber : Dokumen Penelitian

Gambar 24. Pantai Bayem dan Sidem

\subsubsection{Lokasi Tanah Timbul di Kabupaten Pasuruan dan Kota Pasuruan}

Sekitar dua per tiga pantai Pasuruan merupakan pantai landai dengan kemiringan lereng kurang dari $3 \%$ dan banyak sungai bermuara di daerah ini. Sungai-sungai tergaris tersebut membawa sedimen dari daratan dan mengendapkannya di sekitar muara sungai menyebabkan garis pantai semakin lama semakin maju ke arah laut. Pantai dengan kemiringan kurang dari $5 \%$ dikategorikan sebagai pantai datar. Pada pantai landai ini material pantai didominasi oleh lumpur dan substrat ini sangat baik untuk pertumbuhan vegetasi mangrove. Secara alami sebagian besar pantai Pasuruan sangat cocok untuk pertumbuhan vegetasi mangrove, oleh sebab itu di masa lalu ketebalan hutan mangrove di pantai Pasuruan mencapai ratusan meter bahkan ada yang melebihi satu kilometer. ${ }^{27}$

27 Eko Kusratmoko (2000) Klasifikasi Wilayah Pantai Di Indonesia . Proc. Seminar Nasional Pengelolaan Ekosistem Pantai dan Pulau-pulau Kecil Dalam Konteks Negara 
Terbatasnya tanah membuat masyarakat membabat hutan mangrove dan menjadikan tambak baik untuk tambak udang, bandeng maupun garam, bahkan perlahan-lahan menjadi rumah.

Tanah timbul di Kabupaten dan Kota Pasuruan terletak di pantai utara yang berbatasan dengan Selat Madura. Data dari Kantor Pertanahan Kabupaten Pasuruan, sampai dengan tahun 2017 luas tanah timbul menjadi 59,94 Ha. Areal tanah timbul tersebut terbagi meliputi dua wilayah kecamatan, yaitu Kecamatan Kraton dan Rejoso. Untuk luas tanah timbul per desa dapat dilihat pada Tabel 12.

Sedangkan untuk Kota Pasuruan lokasi tanah timbul berada di Kecamatan Bugul Kidul tepatnya di Kelurahan Kepel dan Blandongan. Penambahan daratan di Kelurahan Blandongan diperkirakan lebih kurang 400 ha, dengan jarak dari pantai sekitar $4 \mathrm{~km}$, sedangkan untuk kelurahan Kepel, diperkirakan penambahan berkisar 150 ha (Tabel 13).

Tanah timbul di kelurahan Blandongan, menurut informasi Kasi Penataan Kawasan Tertentu Kanwil BPN Provinsi jawa Timur, diindikasikan terjadi karena adanya perbuatan manusia salah satunya menahan pasir dengan menanam bambu yang lama kelamaan akan menebal dan setelah stabil dijadikan tambak. Fenomena seperti ini dikenal sebagai tanah oloran (mud island). Menurut masyarakat setempat dikatakan tanah oloran karena kenyataan yang ada di daerah tersebut tanah kampung yang semula dekat dengan laut menjadi molor atau panjang sehingga jauh dari permukaan air laut sebagai hasil proses pengendapan lumpur (sedimentasi).

Tabel 36. Luasan Tanah Timbul per Desa di Kabupaten Pasuruan

\begin{tabular}{|l|l|r|}
\hline \multicolumn{1}{|c|}{ Kecamatan } & \multicolumn{1}{|c|}{ Desa } & \multicolumn{1}{c|}{ Luas (Ha) } \\
\hline Rejoso & Jarangan & 20,74 \\
\hline Kraton & Semare & 39,20 \\
\hline \multicolumn{2}{|c|}{ Jumlah } & $\mathbf{5 9 , 9 4}$ \\
\hline
\end{tabular}

Tabel 37. Luasan Tanah Timbul per Kelurahan di Kota Pasuruan

\begin{tabular}{|l|l|r|}
\hline \multicolumn{1}{|c|}{ Kecamatan } & \multicolumn{1}{|c|}{ Kelurahan } & Luas (Ha) \\
\hline Bugulkidul & Blandongan & 400 \\
\hline & Kepel & 150 \\
\hline \multicolumn{2}{|c|}{ Jumlah } & $\mathbf{5 5 0}$ \\
\hline
\end{tabular}

Lokasi tanah timbul di Desa Jarangan (Kabupaten Pasuruan) berada menyatu dengan lokasi tanah timbul kelurahan Kepel dan Blandongan (Kota Pasuruan). 


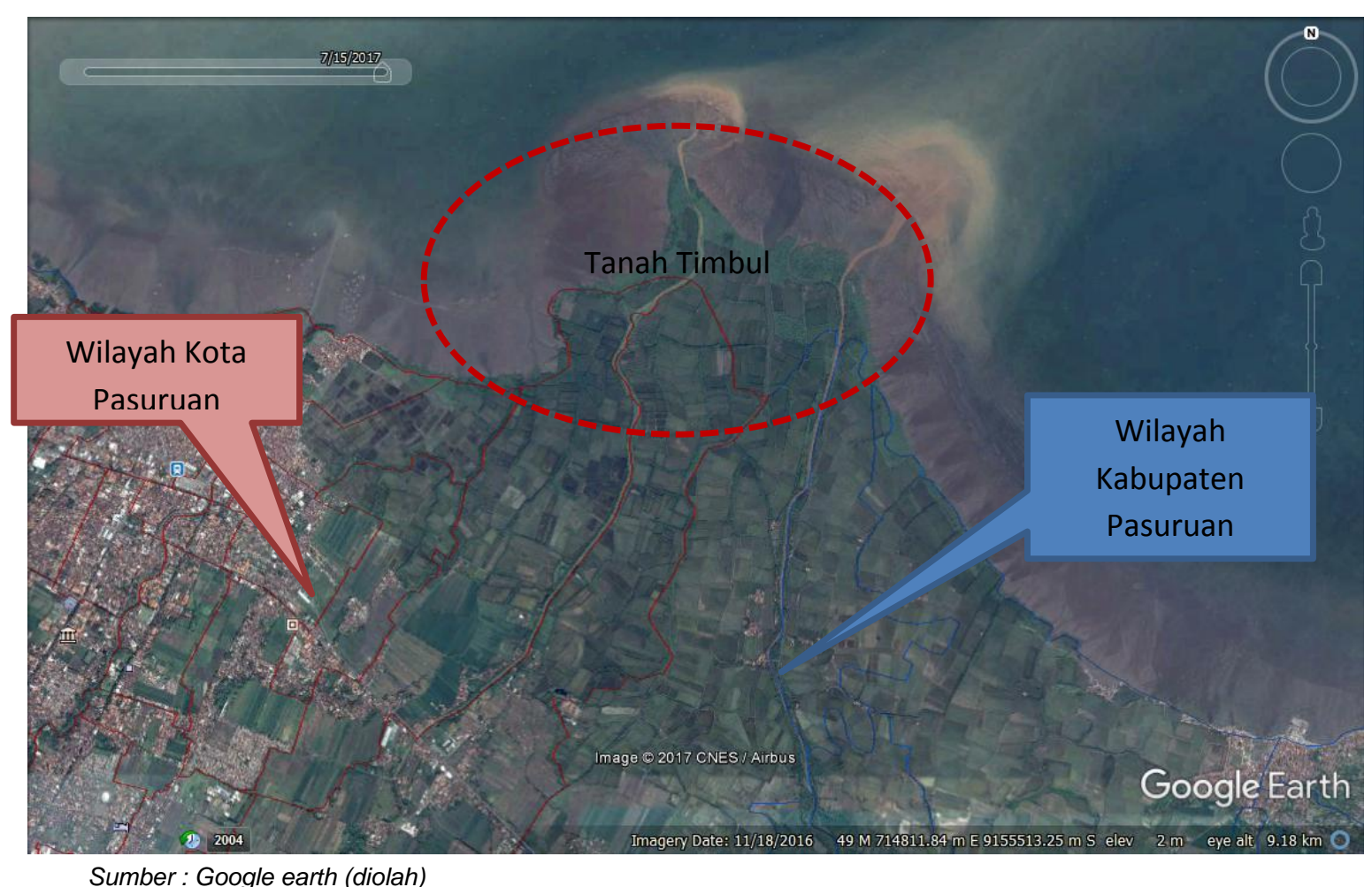

Gambar 25. Tanah Timbul di wilayah Kota Pasuruan dan Kabupaten Pasuruan

\subsubsection{Lokasi Tanah Timbul di Kabupaten Mojokerto}

Kabupaten Mojokerto terletak di bagian tengah dari Provinsi Jawa Timur sehingga tidak memiliki wilayah pantai. Potensi keberadaan tanah timbul di kabupaten ini berada di Daerah Aliran Sungai Brantas yang mengalir membelah wilayahnya. Berdasarkan informasi dari Kantor Pertanahan, lokasi tanah timbul terdapat di Kecamatan Gedeg.

Tabel 38. Lokasi Tanah Timbul di Kabupaten Mojokerto

\begin{tabular}{|l|l|l|r|}
\hline No. & Kecamatan & Desa & Luas (ha) \\
\hline 1. & Gedeg & Kemantren & 14,04 \\
& & Gembongan & 6,69 \\
& & Gedeg & 1,45 \\
& & Gembolkerep & 5,46 \\
& & Ngareskidul & 1,14 \\
& & Pagerluyung & 1,74 \\
& & Terusan & 8,76 \\
\hline \multicolumn{2}{|c|}{ Jumlah } \\
\end{tabular}

Sampel peninjauan lapang yang diambil adalah dua lokasi tanah timbul masing-masing di Desa Kemantren dan Gembongan. Tanah timbul yang dimaksud pada kedua lokasi terlihat secara fisik berupa daratan yang terletak diantara tepi Sungai Brantas dan tanggul sungai (Gambar 25). 


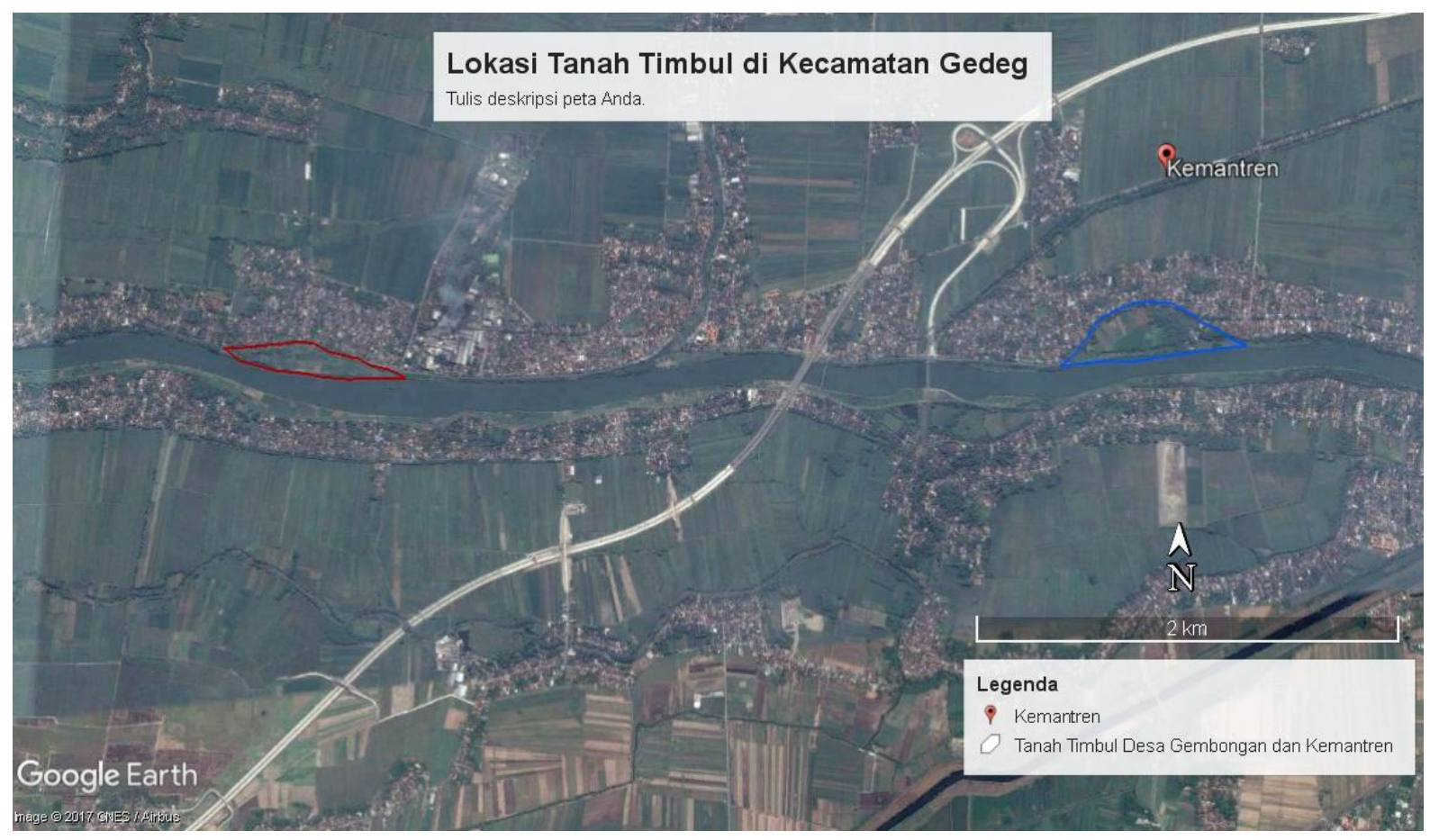

Sumber : Google Earth (diolah)

Gambar 26. Lokasi Tanah Timbul Desa Kemantren dan Gedeg

\subsubsection{Lokasi Tanah Timbul di Kota Cirebon}

Tanah timbul di Berdasarkan data dari Kantor Pertanahan Kota Cirebon, sampai dengan tahun 2017 luas tanah timbul di wilayah Kota Cirebon bertambah sebanyak \pm 887,34 Ha. Dari areal seluas $\pm 887,34$ Ha tersebut terbagi ke 2 wilayah kecamatan, yaitu Kecamatan Lemahwungkuk seluas 690,03 Ha dan Kecamatan Kejaksan seluas 197,31 Ha. Untuk luas tanah timbul per desa dapat dilihat pada Tabel 38. Proses sedimentasi di sepanjang pantai Kota Cirebon menyebabkan banyaknya tanah timbul di pesisir pantai yaitu daerah Kasepuhan, Kebonbaru, Panjunan, Lemahwungkuk, pegambiran, Kebonbaru dan Kesenden. Dengan fenomena ini, tidak menutup kemungkinan bila setiap tahun luas daerah kota Cirebon terus bertambah.

Tabel 39. Luasan Tanah Timbul per Desa di Kota Cirebon

\begin{tabular}{|l|l|r|}
\hline \multicolumn{1}{|c|}{ Kecamatan } & \multicolumn{1}{c|}{ Desa } & \multicolumn{1}{c|}{ Luas (Ha) } \\
\hline Lemahwungkuk & Lemahwungkuk & 0,55 \\
\hline & Panjunan & 128,8 \\
\hline & Pegambiran & 494,6 \\
\hline & Kasepuhan & 66,08 \\
\hline & & $\mathbf{6 9 0 , 0 3}$ \\
\hline Kejaksan & Kebonbaru & $\mathbf{7 2 , 3 1}$ \\
\hline & Kesenden & 125 \\
\hline & & $\mathbf{1 9 7 , 3 1}$ \\
\hline
\end{tabular}

Sumber : Kantor Pertanahan Kota Cirebon 
Adanya tanah timbul ini menjadi potensi pengembangan wilayah kota Cirebon. Dalam Perda No. 7 tahun 1986 tentang Rencana Induk Kota, diketahui wilayah Kota Cirebon seluas 3.735,82 hektar, namun hasil perhitungan berdasarkan citra satelit Ikonos skala $1: 25.000$ menunjukkan adanya penambahan luas daratan menjadi 3.810 ha. Luasan ini kemudian diakui dalam Perda No. 7 tahun 2012 tentang RTRW Kota Cirebon tahun 2012-2032. Dari overlay citra tahun 1994 - 2014, hasil pengolahan citra landsat 5 tahun 1994 dan landsat 8 tahun 2014 menunjukkan adanya proyeksi perubahan tanah pesisir pantai dengan estimasi lebih kurang 100 hektar.

Berdasarkan hasil data lapang penelitian, tanah timbul yang disebut dengan istilah a cukul dewek (tanah tumbuh sendiri) sudah banyak yang menjadi perumahan, seperti di kelurahan kesenden, terdapat perumahan Jala Kesenden lebih kurang 100 bidang (luas masing-masing $72 \mathrm{~m} 2$, termasuk rumah subsidi). Di kelurahan Panjunan, terdapat perkampungan nelayan, Masjid, PAUD dan Pelabuhan Cirebon yang dikelola Pelindo, di lokasi ini menjadi obyek PTSL sebanyak 90 bidang. Demikian pula di kelurahan lemah wungkuk, terdapat perkampungan nelayan dan masjid. Adapun tanah yang sudah bersertipikat, perolehan haknya melalui proses pemberian hak. Tanah timbul di kelurahan Pegambiran berbatasan dengan kabupaten Cirebon, terdapat Pelabuhan Cirebon yang dikelola Pemerintah Daerah, Masjid, pabrik sumpit dan Krematorium Yayasan Pancaka Seroja. Pensertipikatan tanahnya melalui Prona pada tahun 2012.
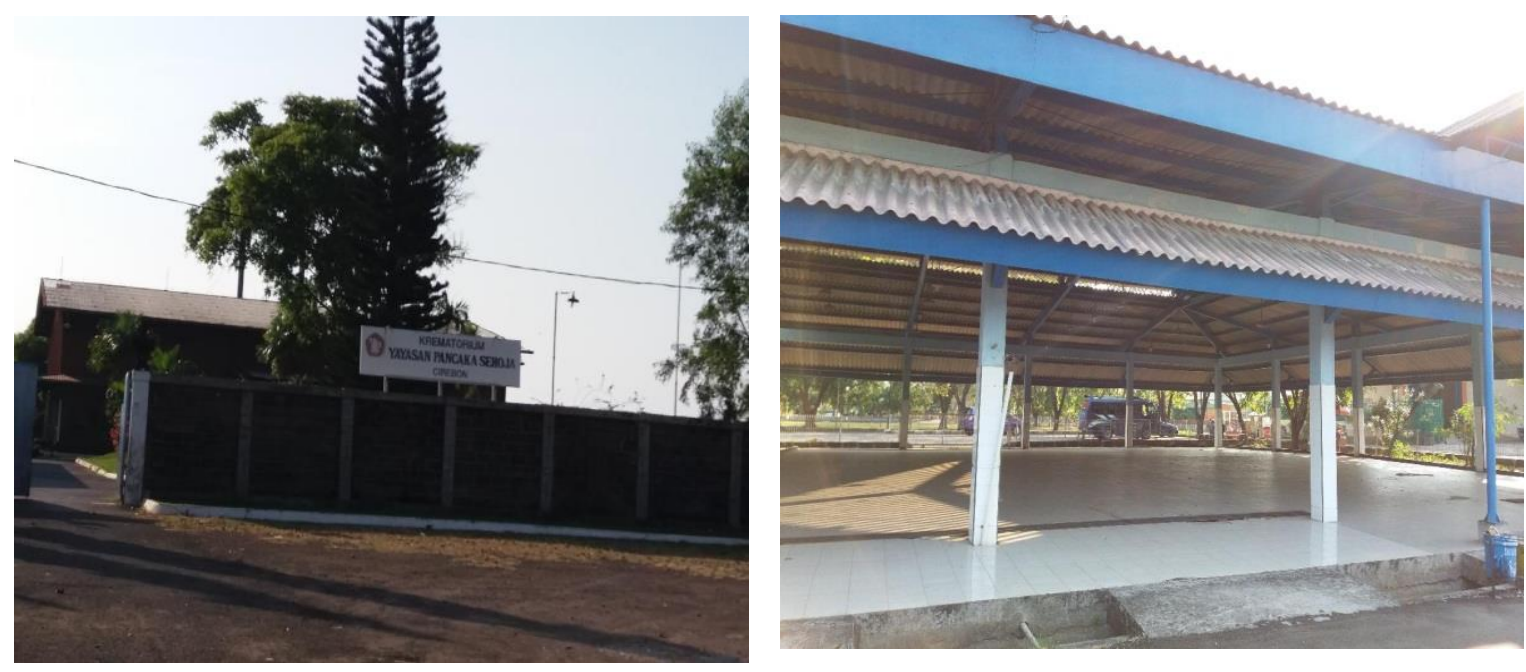

Gambar 27. Tanah timbul di Kelurahan Pegambiran untuk crematorium dan pelabuhan 

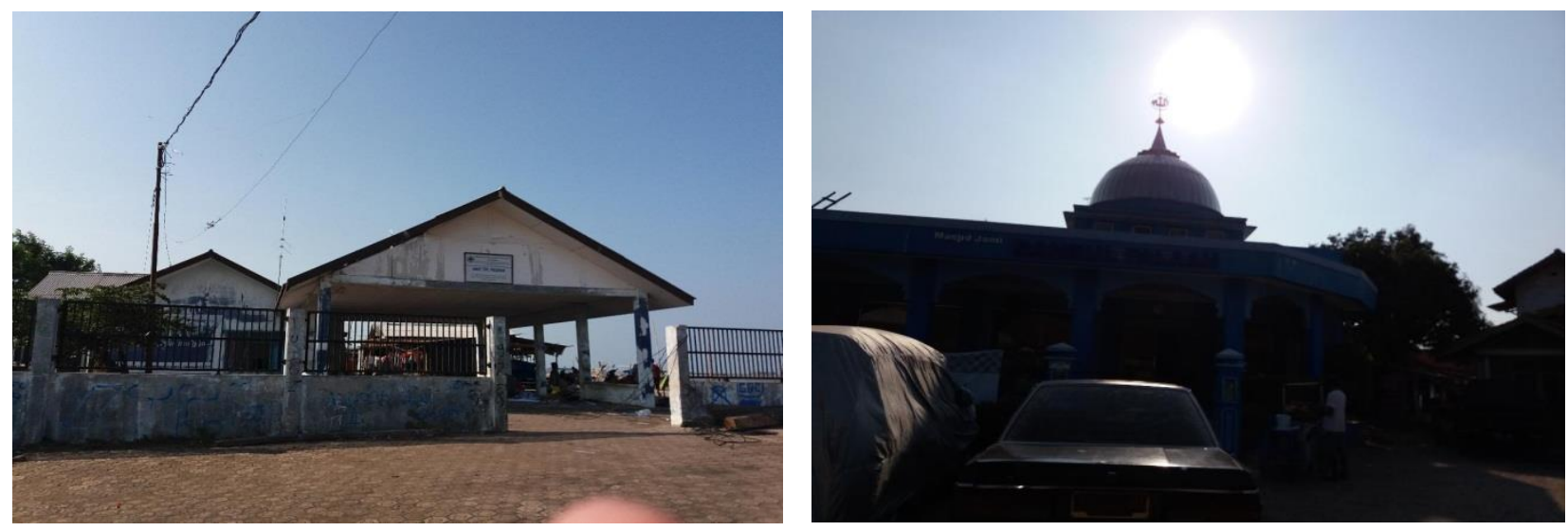

Gambar 28. Tanah Timbul di Kelurahan Panjunan untuk TPI dan Masjid
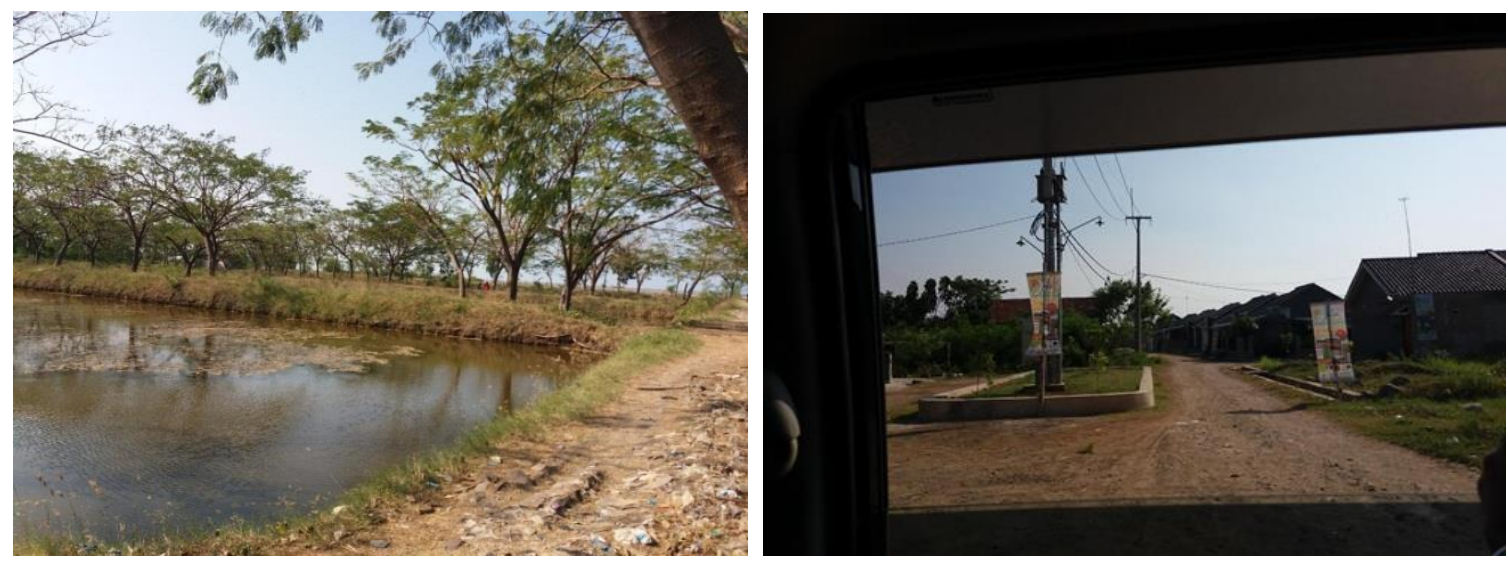

Gambar 29.Tanah timbul di kelurahan kesenden untuk tambak dan perumahan Jala Kesenden 


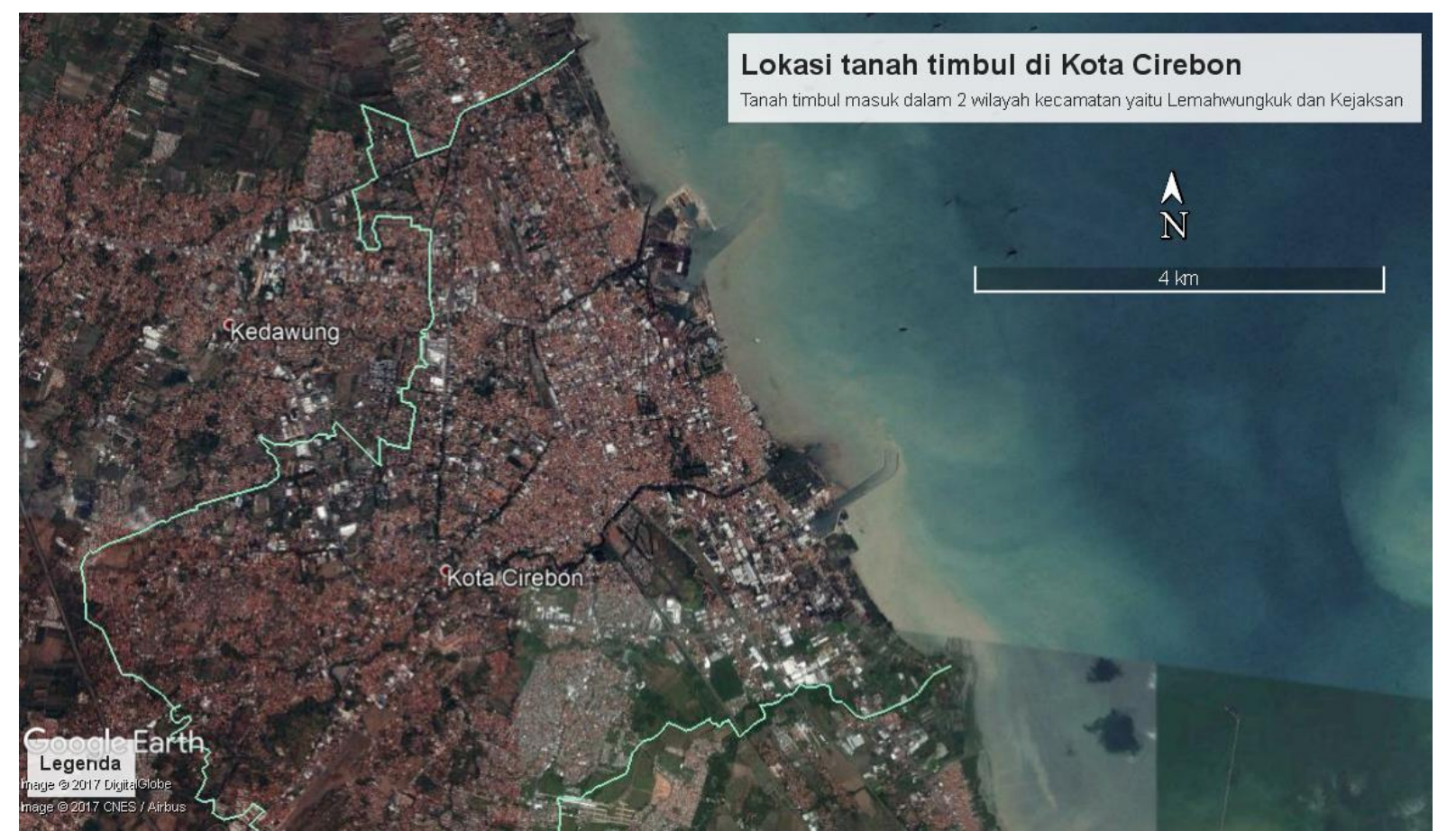

Sumber : Google Earth

Gambar. 30 Lokasi Tanah Timbul di Kota Cirebon

\subsubsection{Lokasi Tanah Timbul di Kabupaten Cirebon}

Kabupaten Cirebon dilalui 2 Daerah Aliran Sungai (DAS) yaitu DAS Cisanggarung dan DAS Cimanuk Hilir. Hali tersebut menyebabkan banyak material-material hasil erosi yang terbawa oleh aliran sungai menuju ke laut. Material yang dibawa oleh aliran sungai tersebut kemudian membentuk sedimentasi di sepanjang pantai di sekitar muara. Sedimentasi yang semakin banyak dalam proses yang lama akan membuat daratan baru yang mengubah garis pantai semakin ke depan. Daratan baru inilah yang disebut dengan tanah timbul.

Dengan terbentuknya tanah timbul merupakan berkah bagi masyarakat di daerah sekitarnya. Tanah timbul tersebut akan dapat dimanfaatkan oleh masyarakat sebagai lahan usaha bagi perekonomian mereka. Keberadaan Tanah timbul ini terkadang bisa menimbulkan konflik di masyarakat karena adanya saling klaim lahan tersebut. Namun hal tersebut tidak sampai menimbulkan masalah, karena akan diselesaikan dengan cara mediasi dari pihak Pemerintah Desa. Di samping menjadi penengah adanya konflik, Pemerintah Desa juga berwenang dalam memberikan ijin penggarapan lahan di lokasi tanah timbul.

Keberadaan tanah timbul di Kabupaten Cirebon menghampar dari perbatasan dengan Kota Cirebon ke arah timur, sampai perbatasan dengan Kabupaten Brebes Jawa Tengah. Tanah timul di Kabupaten Cirebon tersebar di 4 kecamatan dan 19 desa, dengan luas total \pm $1.069,7 \mathrm{Ha}$. 
Tabel 40. Luasan Tanah Timbul per Desa di Kabupaten Cirebon

\begin{tabular}{|c|c|c|}
\hline Kecamatan & Desa & Luas (Ha) \\
\hline \multirow{4}{*}{ Mundu } & Mundu Pesisir & 27,5 \\
\hline & Bandengan & 15 \\
\hline & Citemu & 25 \\
\hline & Waruduwur & 25 \\
\hline \multicolumn{2}{|l|}{ Luas Total } & 92,5 \\
\hline \multirow{5}{*}{ Pangenan } & Pangenan & 50 \\
\hline & Ender & 20 \\
\hline & Wrawa Urip & 126 \\
\hline & Bendungan & 9,2 \\
\hline & Pengarengan & 250 \\
\hline \multicolumn{2}{|l|}{ Luas Total } & 455,2 \\
\hline \multirow{6}{*}{ Gebang } & Melakasari & 20 \\
\hline & Playangan & 20 \\
\hline & Gebang Kulon & 40 \\
\hline & Gebang Ilir & 15 \\
\hline & Gebang Mekar & 20 \\
\hline & Kalipasung & 25 \\
\hline \multicolumn{2}{|l|}{ Luas Total } & 140 \\
\hline \multirow{4}{*}{ Losari } & Tawangsari & 237 \\
\hline & Kalisari & 150 \\
\hline & Kalirahayu & 20 \\
\hline & Ambulu & 50 \\
\hline \multicolumn{2}{|l|}{ Luas Total } & 457 \\
\hline
\end{tabular}

Dari Tabel di atas dapat dilihat, bahwa tanah timbul di kabupaten Cirebon paling luas terdapat di kecamatan Losari, lebih kurang 457 ha, terluas ada di desa Tawangsari. Kemudian kecamatan Pangenan terdapat tanah timbul seluas lebih kurang 455,2 ha, terluas di desa pengarengan. Luas tanah timbul di kecamatan Gebang lebih kurang 140 ha, terluas di desa gebang kulon. Sedangkan di Kecamatan Mundu lebih kurang 92,5 ha, terluas di desa Mundu Pesisir.

Kawasan pantai Kecamatan Mundu hingga Kecamatan Losari hampir seluruhnya terdiri dari pantai berlumpur, Hal ini disebabkan oleh adanya dua sungai yang bermuatan sedimen cukup besar bermuara di kawasan pantai timur ini. Lumpur berwarna hitam kecoklatan terkadang mengandung cangkang kerang, membentuk pantai amat landai dengan sudut sekitar $2^{\circ}$ hingga $4^{\circ}$. Geometri pantai secara regional membentuk teluk-teluk dan pada muara-muara sungai yang menjorok ke arah laut terbentuk tanjung akibat material sedimen yang termuat pada sungai-sungai terendapkan di mulut muara. Kondisi ini yang dapat terlihat pada citra satelit landsat 7 ETM+ Kabupaten Cirebon dengan amat jelas memperlihatkan adanya proses akrasi dan pendangkalan di wilayah muara-muara sungai. Sebaran sedimen berbutir halus yang tersebar jauh ke arah laut mengakibatkan tingginya derajat kekeruhan air laut dan 
pendangkalan. Pada citra satelit, dapat dilihat pergerakan material sedimen dalam air laut akibat arus laut yang bergerak di sekitar kawasan pesisir maupun di laut yang lebih dalam. Proses pengendapan material sedimen sepanjang garis pantai yang membentuk daratan baru dimanfaatkan masyarakat untuk perluasan tambaknya, baik usaha tambak udang, garam maupun ikan laut. Kawasan daratan baru tersebut masih dipengaruhi oleh aktivitas pasang surut yang sangat memudahkan masyarakat untuk mendapatkan air laut guna menggenangi lahan tambaknya. Kawasan pesisir yang sudah tidak terpengaruh oleh air laut diubah pemanfaatannya, dari lahan. ${ }^{28}$

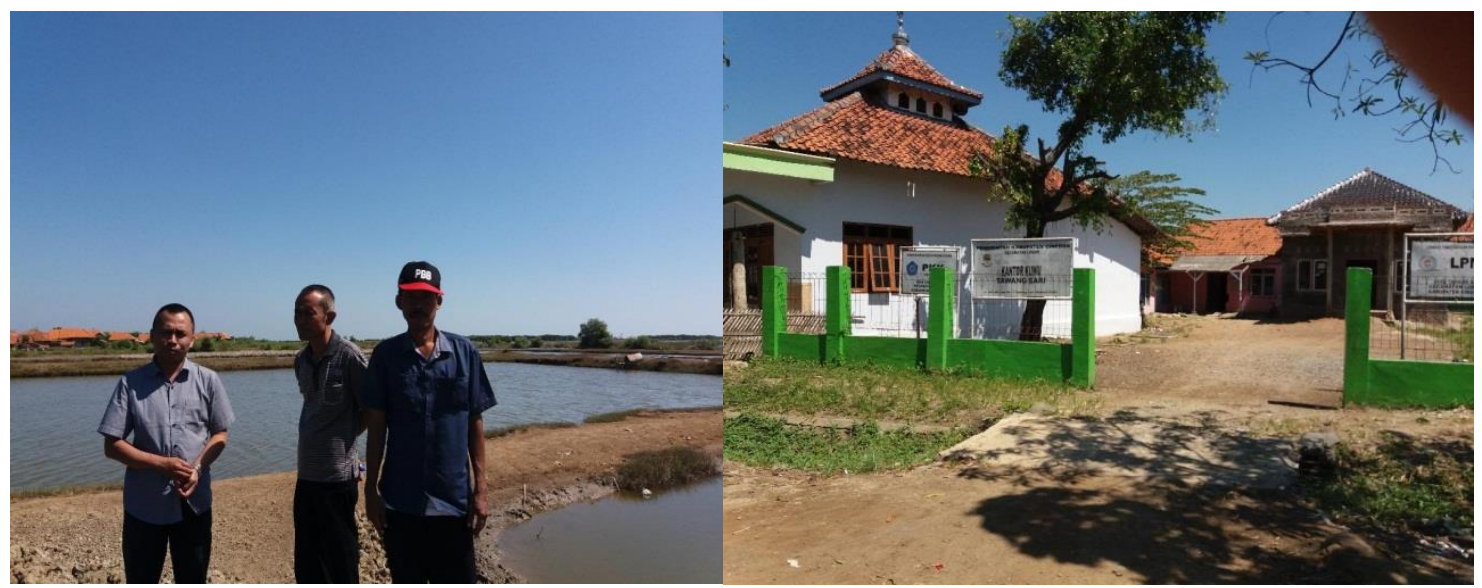

Gambar 31. Iokasi tanah timbul di Kecamatan Losari untuk tambak dan Kantor Kuwu.

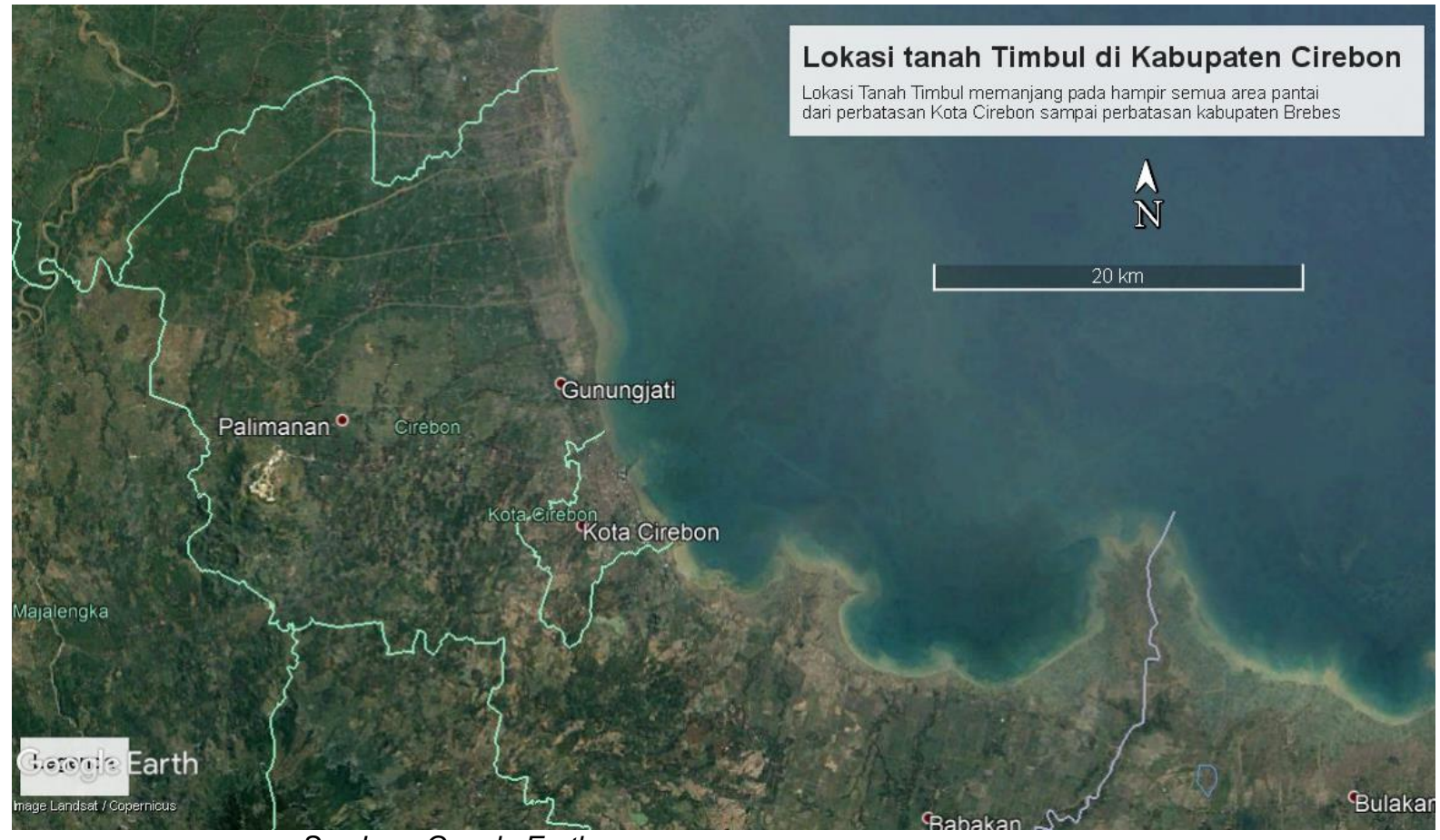

Sumber : Google Earth

Gambar 32. Lokasi Tanah Timbul di Kabupaten Cirebon

${ }^{28}$ P. Astjario dan FX. Harkins, Penelitian Lingkungan Pantai Wilayah Pesisir Kabupaten Cirebon, jawa barat, 2005 


\subsubsection{Lokasi Tanah Timbul di Kabupaten Indramayu}

Wilayah pesisir Indramayu Jawa Barat dengan panjang garis pantai lebih kurang $114 \mathrm{~km}$ merupakan salah satu daerah pantai utara Jawa Barat yang sangat strategis dan berkembang dalam aktivitasnya sebagai daerah penyangga kawasan industry. Proses erosi pantai (abrasi) di daerah Indramayu berlangsung cukup kuat, sehingga garis pantai telah mundur jauh dari garis pantai lama dan sudah mendekati jalan raya Indramayu - Jakarta, yang pada saat ini bersisa jarak hanya kurang lebih 100 meter dari tepi laut. ${ }^{29}$

Berdasarkan data dari Pemerintah Daerah Kabupaten Indramayu, tanah timbul di Kabupaten Indramayu tersebar di 6 kecamatan dan 15 desa, dengan luas total $\pm 1.935,39 \mathrm{Ha}$.

Tabel 41. Luasan Tanah Timbul per Desa di Kabupaten Indramayu

\begin{tabular}{|c|c|c|c|}
\hline Kecamatan & Desa & $\begin{array}{l}\text { Luas } \\
\text { (m2) }\end{array}$ & $\begin{array}{c}\text { LUAS } \\
(\mathrm{Ha})\end{array}$ \\
\hline \multirow[t]{3}{*}{ Kandanghaur } & Pareangirang & 1213249 & 121,32 \\
\hline & llir & 683420 & 68,34 \\
\hline & & 1896669 & 189,67 \\
\hline \multirow[t]{4}{*}{ Krangkeng } & Krangkeng & 155562 & 15,56 \\
\hline & Luwunggesik & 646439 & 64,64 \\
\hline & Kalianyar & 878997 & 87,90 \\
\hline & & 1680998 & 168,10 \\
\hline \multirow[t]{3}{*}{ Balongan } & Majakerta & 32640 & 3,26 \\
\hline & Balongan & 34780 & 3,48 \\
\hline & & 67420 & 6,74 \\
\hline \multirow[t]{5}{*}{ Indramayu } & Singajaya & 152620 & 15,26 \\
\hline & Singaraja & 61172 & 6,12 \\
\hline & Karangsong & 60860 & 6,09 \\
\hline & Pabean Udik & 1541774 & 154,18 \\
\hline & & 1816426 & 181,64 \\
\hline \multirow[t]{3}{*}{ Pasekan } & Brondong & 1179705 & 117,97 \\
\hline & Pabean Ilir & 4111019 & 411,10 \\
\hline & & 5290724 & 529,07 \\
\hline \multirow[t]{4}{*}{ Cantigi } & Lamaran Tarung & 4801425 & 480,14 \\
\hline & Cemara & 3800280 & 380,03 \\
\hline & & 8601705 & 860,17 \\
\hline & Jumlah & 19353942 & $1.935,39$ \\
\hline
\end{tabular}

Tabel di atas dapat dilihat, bahwa tanah timbul di kabupaten Indramayu paling luas terdapat di Kecamatan Cantigi. Hal ini disebabkan pada Kecamatan Cantigi terdapat muara sungai terbesar di Kabupaten Indramayu besar yaitu Sungai Cimanuk.

\footnotetext{
${ }^{29} \mathrm{mgi.esdm.go.id/content/studi-perubahan-garis-pantai-kaitannya-dengan-pengelolaan-wilayah-pesisir} \mathrm{indramayu-}$ jawabarat
} 


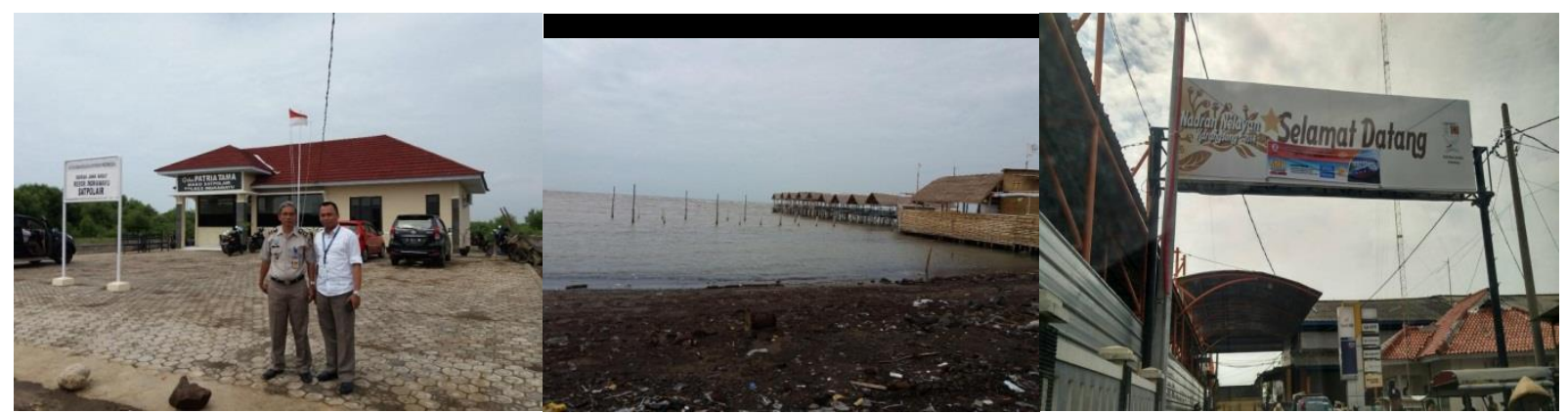

Gambar 33. lokasi tanah timbul, di desa karangsong terdapat TPI, Rumah Makan dan Kantor SATPOL AIR.

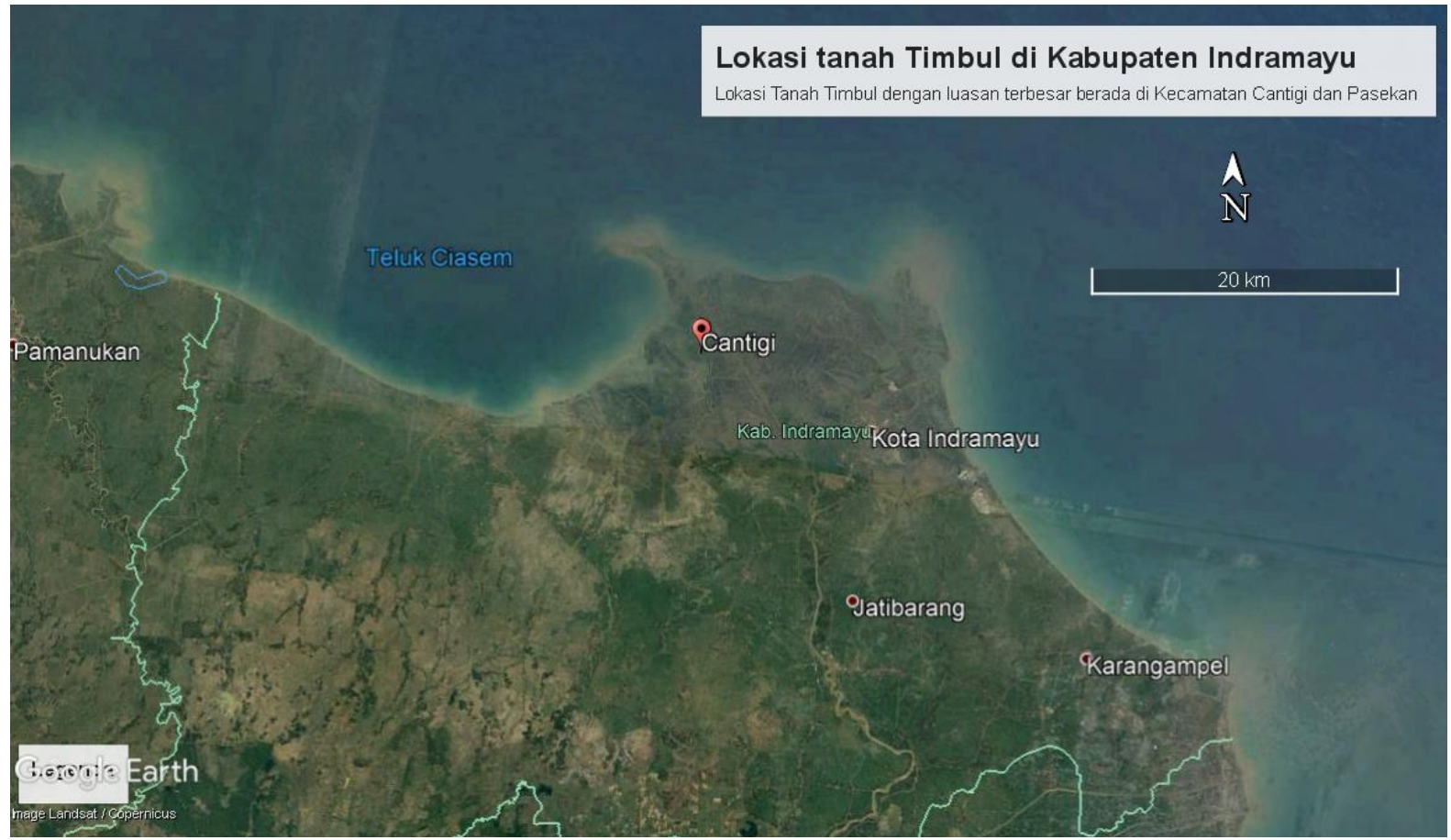

Sumber : Google Earth

Gambar 34. Lokasi Tanah Timbul di Kabupaten Indramayu

\subsubsection{Lokasi Tanah Timbul di Kabupaten Serang}

Keberadaan tanah timbul di Kabupaten Serang mengelompok di bagian timur wilayah pesisir pantai. Tanah timbul di Kabupaten Serang tersebar di 3 kecamatan dan 4 desa, dengan luas total $\pm 256,08 \mathrm{Ha}$. Adapun luasan lebih rinci per desa disajikan pada tabel berikut ini.

Tabel 42. Luasan Tanah Timbul per Desa di Kabupaten Serang

\begin{tabular}{|l|l|r|}
\hline \multicolumn{1}{|c|}{ Kecamatan } & \multicolumn{1}{|c|}{ Desa } & Luas (Ha) \\
\hline Pontang & Sukajaya & 100 \\
\hline & & \\
\hline
\end{tabular}




\begin{tabular}{|l|l|r|} 
Tirtayasa & Tengkura & 90 \\
\hline & & \\
\hline Tanara & Tenjo Ayu & 200 \\
\hline & Pedaleman & 100 \\
\hline & & 490 \\
\hline
\end{tabular}

Dari Tabel di atas dapat dilihat, bahwa tanah timbul di kabupaten Serang paling luas terdapat di Kecamatan Tanara, yaitu sekitar $300 \mathrm{Ha}$. Tanah-tanah timbul yang ada di 3 kecamatan ini disebabkan karena terdapatnya 2 muara sungai besar yaitu Sungai Cidurian dan Sungai Ciujung, yang membuat daerah ini banyak berkumpul material hasil aliran sungai dari hulu. Di samping itu, garis pantai pada wilayah ini merupakan bagian dari Teluk Banten, sehingga membuat proses pengendapan material menjadi lebih cepat, dikarenakan ombak yang tidak begitu kuat.

Tanah timbul pada lokasi desa Sukajaya Kecamatan Pontang seluas 80 ha akan dilaksanakan Konsolidasi Tanah bekerja sama dengan Pemerintah Daerah. 
Citra Google Earth Tahun 1984

\section{Google Earth}

Tahun 2016

Citra Google Earth Tahun 2016

Domas

Google Earth

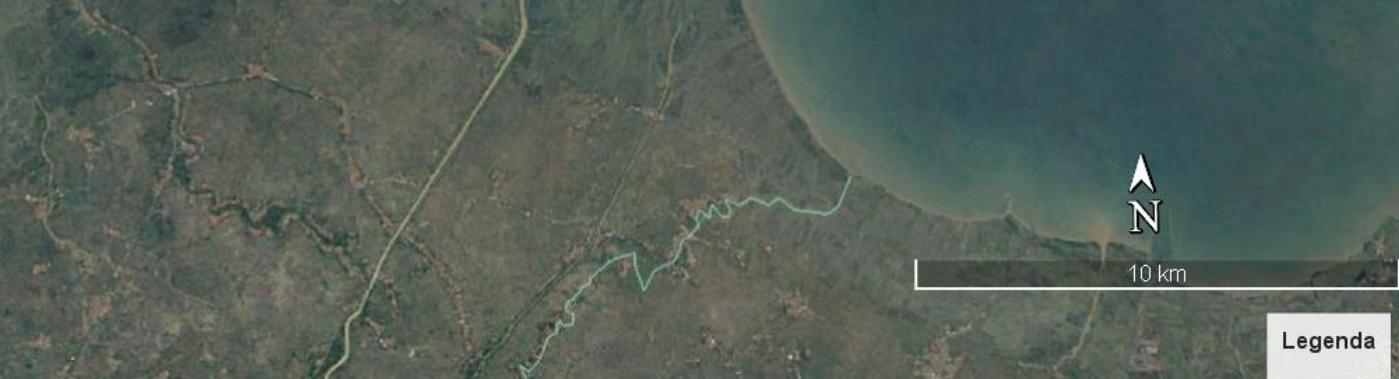

Sumber : Google Earth

Gambar 35. Penambahan daratan di salah satu lokasi tanah timbul Desa Tenjo Ayu Kecamatan Tanara. 


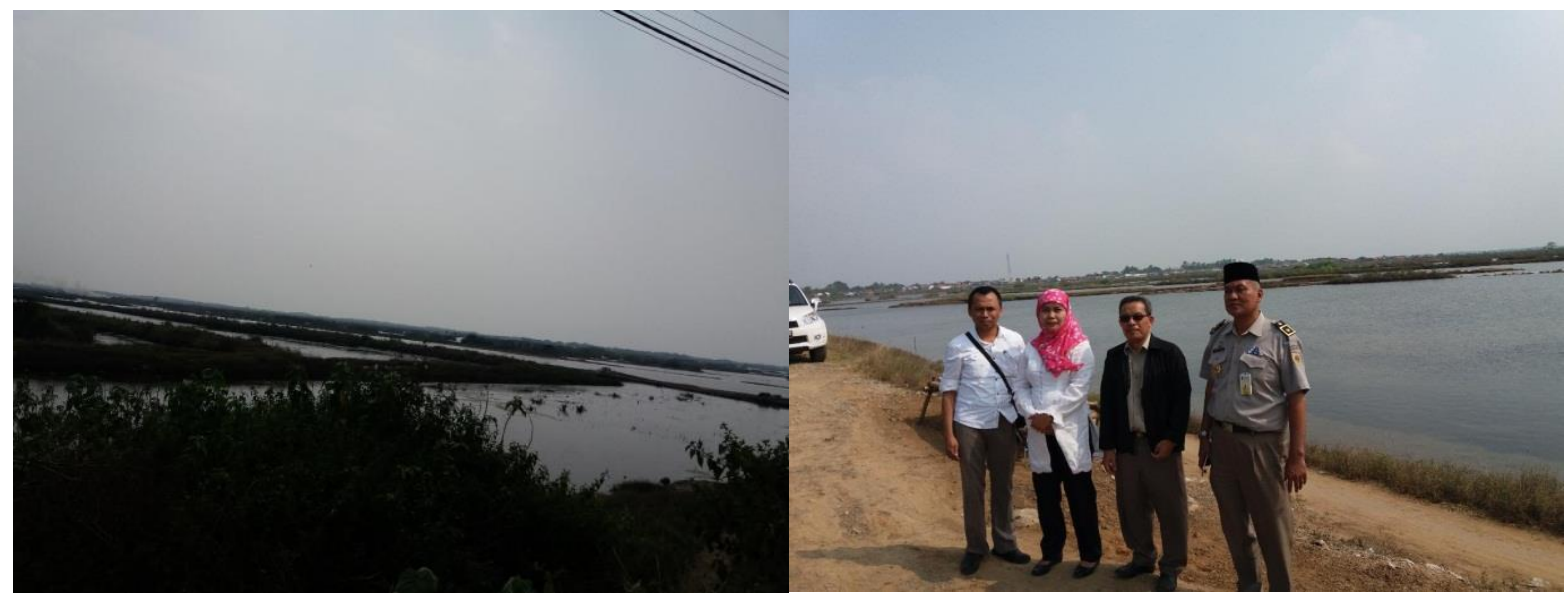

Gambar 36. Tanah timbul di desa Tengkura, Kecamatan Tirtayasa

\subsubsection{Lokasi Tanah Timbul di Kabupaten Tangerang}

Keberadaan tanah timbul di Kabupaten Tangerang tersebar di wilayah pesisir pantai. Tanah timbul di Kabupaten Tangerang tersebar di 5 kecamatan dan 13 desa, dengan luas total $\pm 313,06 \mathrm{Ha}$. Adapun luasan lebih rinci per desa disajikan pada tabel berikut ini.

Tabel 43. Luasan Tanah Timbul per Desa di Kabupaten Tangerang

\begin{tabular}{|c|c|c|}
\hline Kecamatan & Desa & Luas (Ha) \\
\hline \multirow[t]{2}{*}{ Kronjo } & Pagedangan Ilir & 40 \\
\hline & & 40 \\
\hline \multirow[t]{4}{*}{ Mauk } & Ketapang & 50 \\
\hline & Tanjung Anom & 50 \\
\hline & Mauk Barat & 9 \\
\hline & & 109 \\
\hline \multirow[t]{4}{*}{ Pakuhaji } & Surya Bahari & 45 \\
\hline & Kramat & 10 \\
\hline & Kohod & 50 \\
\hline & & 105 \\
\hline \multirow[t]{3}{*}{ Teluk Naga } & Tanjung Burung & 12,79 \\
\hline & Tanjung Pasir & 34,26 \\
\hline & & 47,05 \\
\hline \multirow[t]{6}{*}{ Kosambi } & Salembaran Jaya & 10,51 \\
\hline & Kosambi Barat & 0,81 \\
\hline & Kosambi Timur & 0,12 \\
\hline & Dadap & 0,57 \\
\hline & & 12,01 \\
\hline & & 313,06 \\
\hline
\end{tabular}

Sumber : Kanwil BPN Prov. Banten 
Dari Tabel di atas dapat dilihat, bahwa tanah timbul di kabupaten Tangerang paling luas terdapat di Kecamatan Mauk dan Pakuhaji. Tanah-tanah timbul yang ada di 2 kecamatan ini disebabkan ada muara sungai di sekitar wilayah ini, yaitu muara Sungai Cileleus dan Cirarab untuk Kecamatan Mauk dan muara Sungai Cisadane untuk Kecamatan Pakuhaji.

Tanah-tanah timbul yang ada di Kabupaten Tangerang ini sebagian besar sudah bersertipikat. Ada sedikit tanah timbul yang belum bersertipikat, yaitu di Desa Kohod, Kecamatan Pakuhaji seluas $\pm 25 \mathrm{Ha}$. Di samping itu ada lokasi tanah timbul yang sudah bersertipikat, tetapi tanahnya sudah tidak ada, yaitu terkena abrasi sehingga kondisi sekarang berupa lautan, seperti yang terdapat di Desa Karang Serang, Kecamatan Sukadiri seluas \pm 20 Ha. Hal ini harus menjadikan perhatian semua stakeholder, karena akan menimbulkan masalah seandainya sertipikat tersebut sebagai jaminan pinjaman bank. 


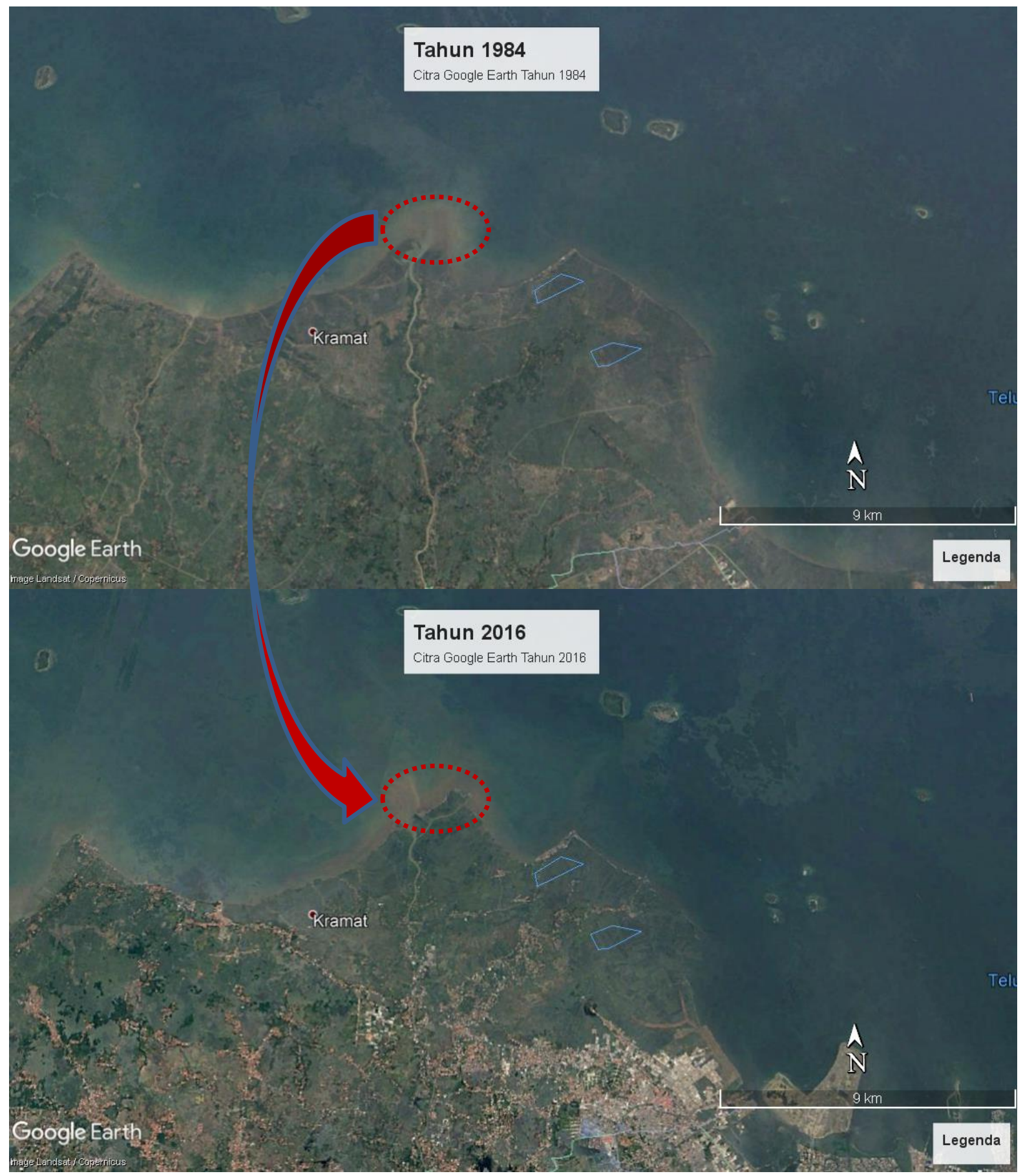

Sumber : Google Earth

Gambar 37. Penambahan daratan di salah satu lokasi tanah timbul Desa Kohod Kecamatan Pakuhaji 


\subsubsection{Lokasi Tanah Timbul di Bengkulu}

Tanah timbul di Kota Bengkulu terindikasi berada di area Sungai Jenggalu dan di daerah pantai terutama Pantai Jakat. Tanah timbul di Sungai Jenggalu berada dalam wilayah dua kelurahan yaitu: Kelurahan Muara Dua dan Kandang di Kecamatan Kampung Melayu. Secara sekilas tanah timbul yang berada di Sungai Jenggalu ini bisa langsung dikenali secara fisik. Lokasinya yang berada di tengah sungai disinyalir terbentuk dari endapan lumpur dari aliran Sungai Jenggalu yang tertahan oleh mangrove sehingga lama kelamaan membentuk "pulaupulau" kecil. Sedangkan informasi tentang waktu mulai terbentuknya pulau-pulau tersebut masih sangat minim.

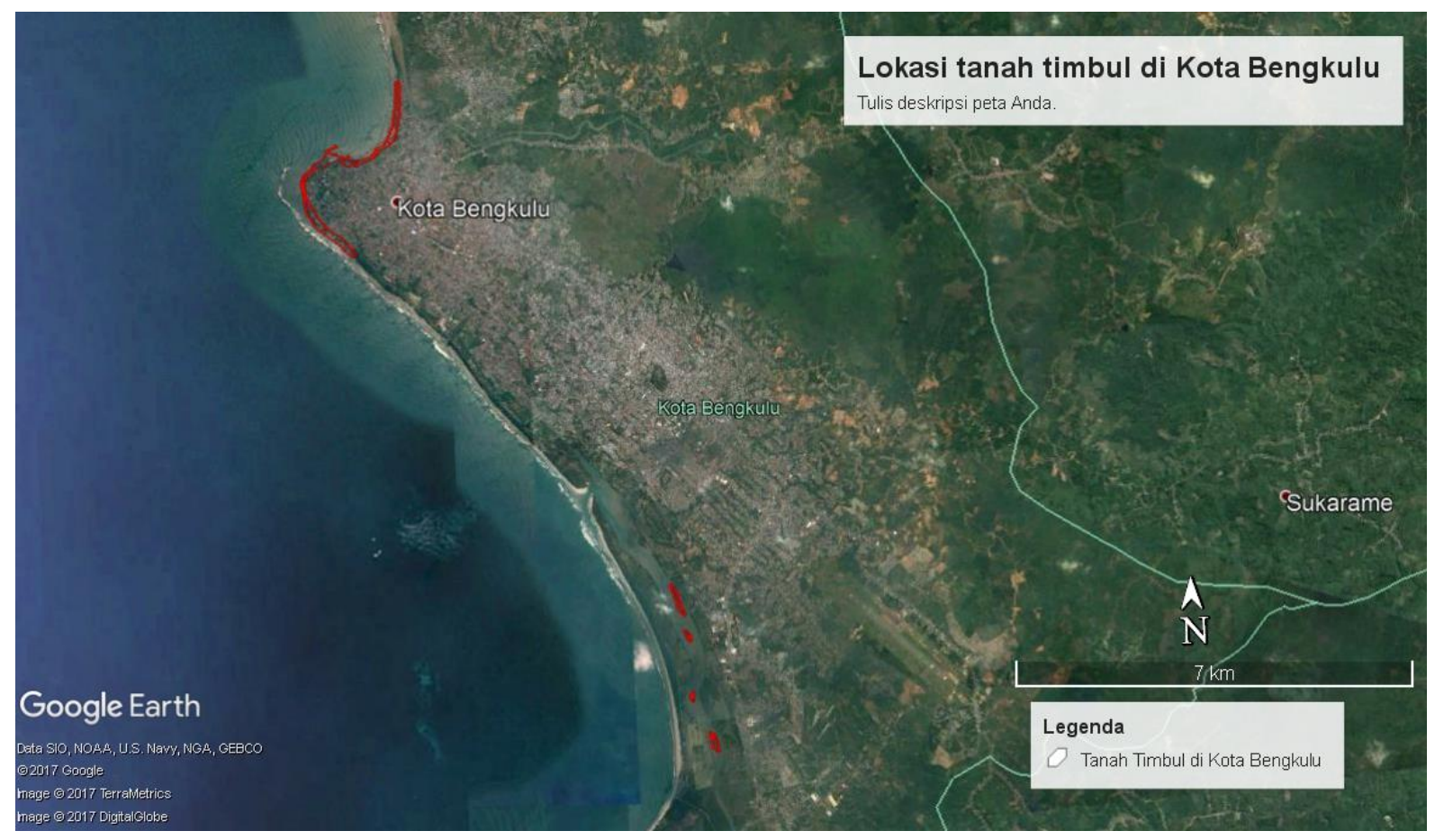

Sumber: Google Earth

Gambar 38. Lokasi tanah timbul di Kota Bengkulu

Pada lokasi Pantai Jakat, tanah timbul tidak secara langsung bisa dikenali. Berdasar pengamatan dilapangan, secara fisik lokasi tersebut berupa pantai yang membentang yang meliputi wilayah Kelurahan Berkas, Sumur Meleleh, Malabero, Kebon Keling, Pondok Besi, Bajak, Tengah Padang di Kecamatan Teluk Segara sampai muara Sungai Serut di Kelurahan Pasar Bengkulu di wilayah Kecamatan Sungai Serut. Informasi awal bahwa lokasi dimaksud merupakan tanah timbul berasal dari narasumber yang merupakan pelaku sejarah yang mengetahui adanya perubahan dan penambahan daratan baru. Seperti yang dikatakan sumber tersebut, telah terjadi penambahan daratan baru pada area sepanjang Pantai Jakat sepanjang kurang lebih 50 sampai 100 meter dari garis pantai saat ini sejak tahun 1968.

Kepastian bahwasanya lokasi merupakan tanah timbul juga dikuatkan dengan melihat Kutipan Peta Bidang Belanda dengan angka tahun 1940. Pada peta tersebut terlihat batas 
bidang tanah yang berbatasan langsung dengan laut saat itu memang tidak seperti kondisi saat ini. Pada lokasi yang masuk wilayah Kelurahan Berkas terlihat pada peta diantara jalan dan pantai hanya terdapat satu baris bidang tanah. Sementara kondisi sekarang sudah terdapat beberapa lapis rumah diantara jalan yang sama dengan pantai sepanjang kurang lebih 100 meter. Selain itu terdapat juga jalan baru, jogging track dan area pantai dengan pemecah ombak. Hal serupa juga ditemukan di wilayah Kelurahan Sumur Meleleh.

Sementara di Kelurahan malabero, pertambahan daratan tidak sebesar pada dua kelurahan sebelumnya. Panjang pertambahan tanah pada sisi barat hanya berkisar 30 meter sementara di sisi utara sepanjang kurang lebih 60 meter. Kemudian di Kelurahan Kebon Keling, tanah timbul terbentuk pada lokasi pelabuhan lama. Endapan tanah menumpuk pada cekungan yang terbentuk dari penahan ombak pelabuhan. Saat ini lokasi ini dipergunakan sebagai mess Pemda. Menurut keterangan aparat kelurahan, tanah timbul ini pernah beberapa kali dilakukan pengerukan tapi kembali terjadi pengendapan sampai akhirnya pihak pemda memanfaatkan dengan membangun mess pemda. Tepat disebelah mess pemda, masih pada lokasi tanah timbul, dibangun kawasan wisata berupa taman dengan dilengkapi kolam.

Penambahan daratan berikutnya terletak pada area teluk dan termasuk dalam wilayah Kelurahan Pondok Besi, Tengah Padang dan Bajak. Panjang penambahan pada lokasi ini bervariasi tapi sebagian besar berkisar antara 50 - 70 meter. Selanjutnya di Kelurahan Pasar Bengkulu yang masuk Kecamatan Sungai Serut indikasi penambahan daratan sekitar 80 - 90 meter dan semakin mengecil sampai pada daerah muara sungai menjadi sekitar 30 meter.

Deliniasi dilakukan diatas kutipan peta tahun 1940 yang di overlay dengan citra tahun 2013 ditambah dengan menggabungkan dengan informasi dari sumber pelaku sejarah, dan pengamatan lapang. Hasil perhitungan luas yang diperoleh adalah telah terjadi penambahan luas daratan sebesar 46,26 hektar. Gambar 3 dan 4 menggambarkan deliniasi penambahan daratan sedang tabel 2 merinci hasil perhitungan luasnya. 


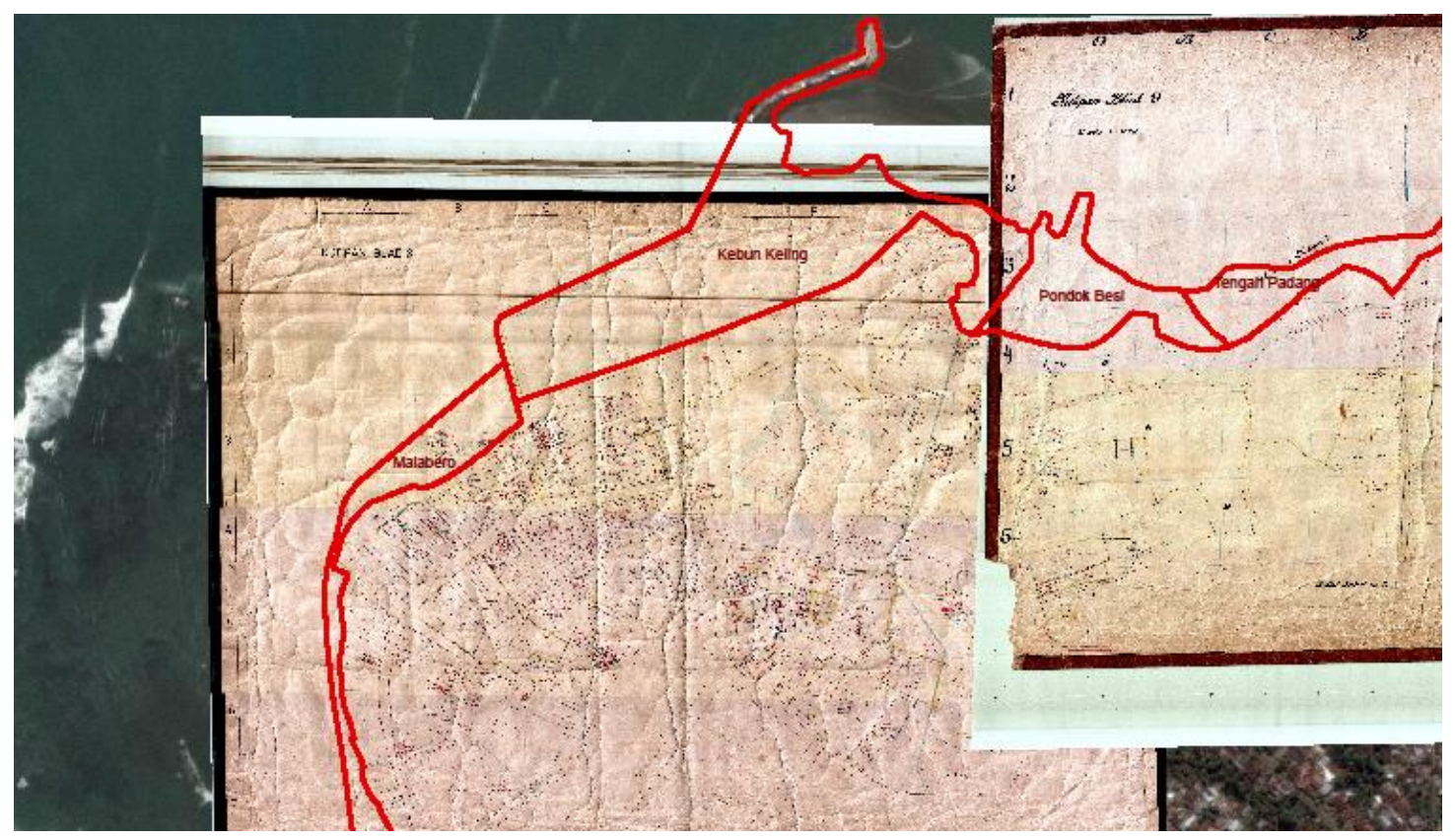

Sumber: Pengolahan data

Gambar 39. Deliniasi tanah timbul diatas kutipan peta tahun 1940

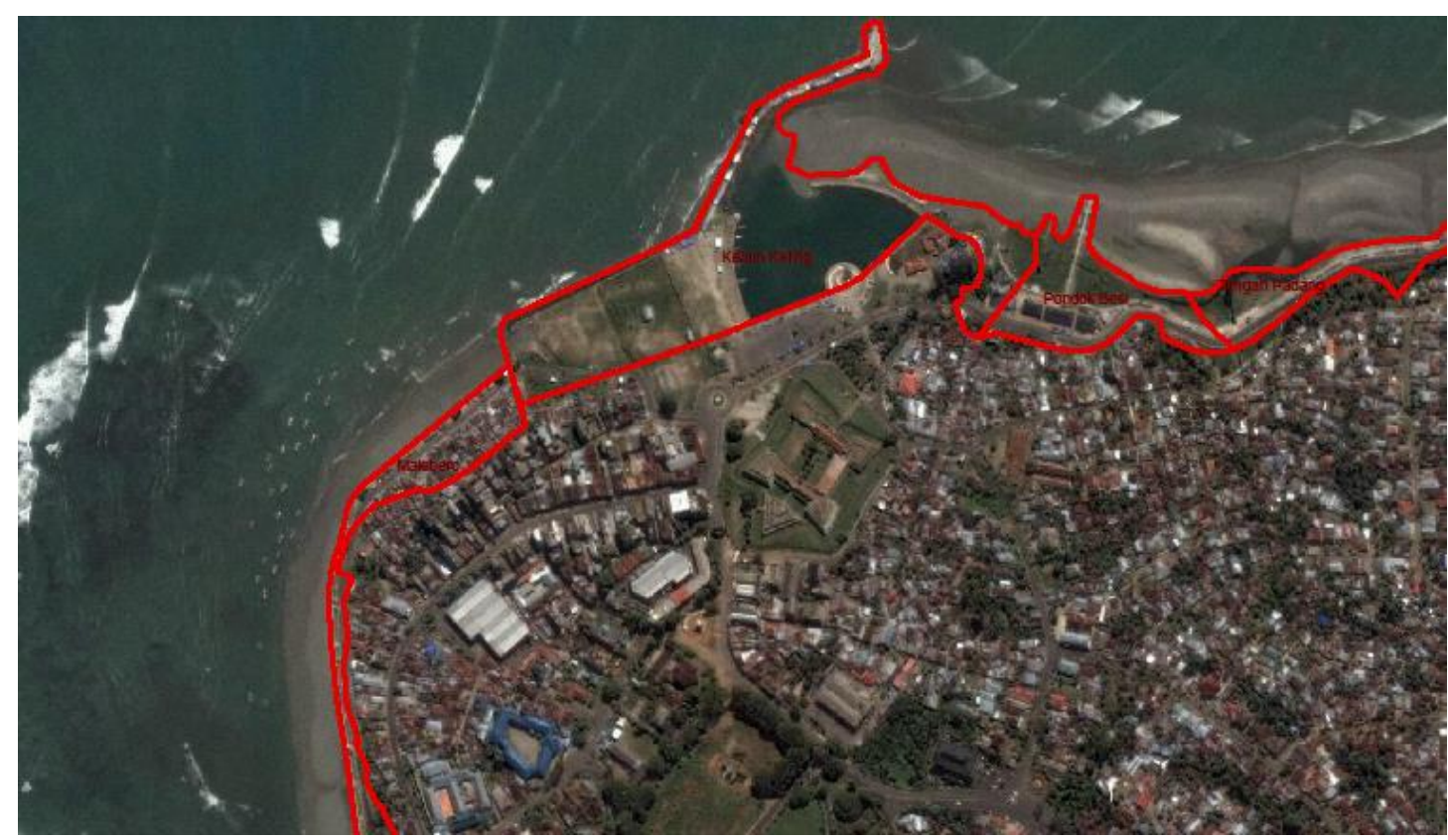

Sumber: Pengolahan data

Gambar 40. Deliniasi tanah timbul diatas Citra tahun 2013 
Tabel 44. Tanah timbul di Kota Bengkulu

\begin{tabular}{|r|l|l|r|}
\hline No & \multicolumn{1}{|l|}{ Kelurahan } & \multicolumn{1}{c|}{ Kecamatan } & \multicolumn{1}{c|}{$\begin{array}{c}\text { Luas } \\
(\mathbf{H a})\end{array}$} \\
\hline 1 & Kandang & $\begin{array}{l}\text { Kampung } \\
\text { Melayu }\end{array}$ & 1,15 \\
\hline 2 & Kandang & $\begin{array}{l}\text { Kampung } \\
\text { Melayu }\end{array}$ & 0,71 \\
\hline 3 & Kandang & $\begin{array}{l}\text { Kampung } \\
\text { Melayu }\end{array}$ & 0,24 \\
\hline 4 & Kandang & $\begin{array}{l}\text { Kampung } \\
\text { Melayu }\end{array}$ & 2,51 \\
\hline 5 & Muara Dua & $\begin{array}{l}\text { Kampung } \\
\text { Melayu }\end{array}$ & 4,1 \\
\hline 6 & Berkas & Teluk Segara & 6,27 \\
\hline 7 & Bajak & Teluk Segara & 1,32 \\
\hline 8 & Pondok Besi & Teluk Segara & 1,95 \\
\hline 9 & Kebun Keling & Teluk Segara & 7,35 \\
\hline 10 & Sumur Meleleh & Teluk Segara & 5,25 \\
\hline 11 & Tengah Padang & Teluk Segara & 1,32 \\
\hline 12 & Malabero & Teluk Segara & 1,97 \\
\hline 13 & Pasar Bengkulu & Sungai Serut & 12,12 \\
\hline \multicolumn{2}{|c|}{ Total } & 46,26 \\
\hline
\end{tabular}

Sumber: Pengolahan data

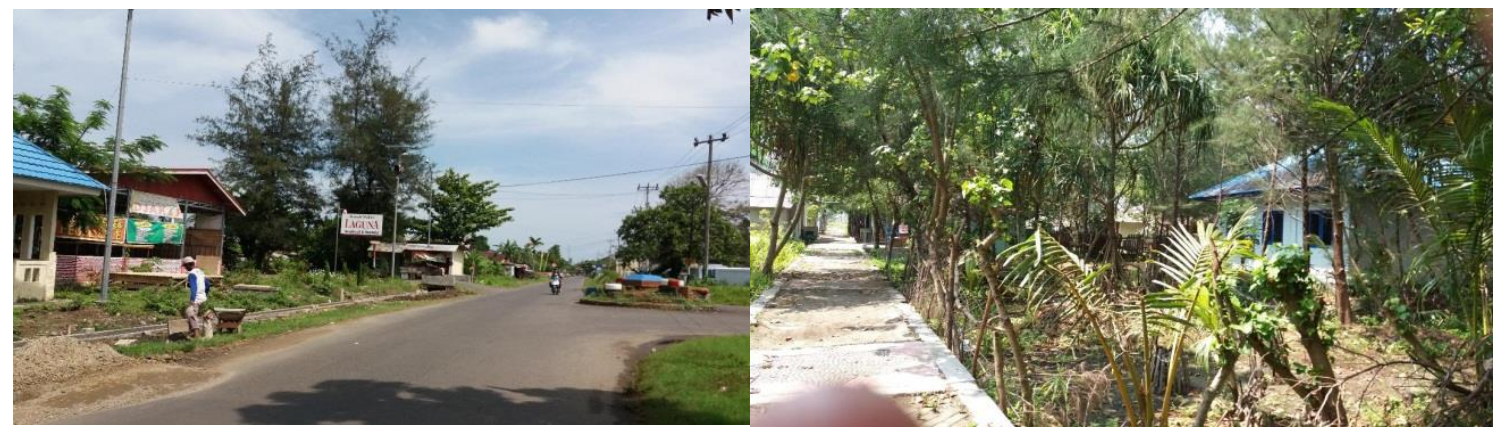

Sumber : Dokumen Penelitian

Gambar 41. Tanah Timbul Kelurahan Berkas (batas jogging track)

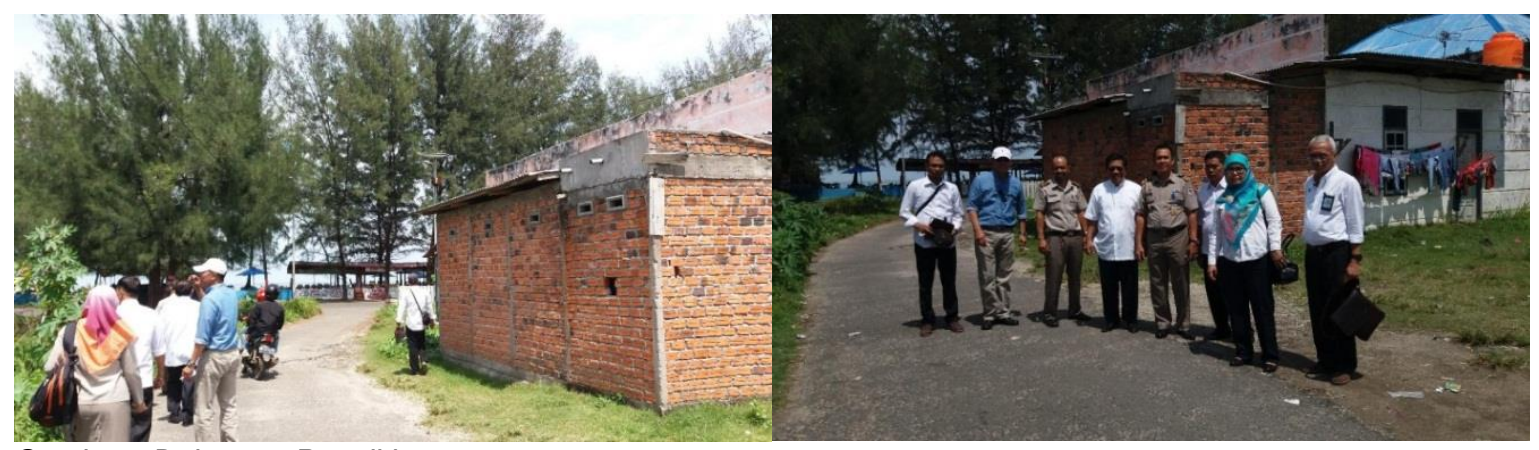

Sumber : Dokumen Penelitian

Gambar 42. Tanah Timbul Kelurahan Sumur Meleleh 

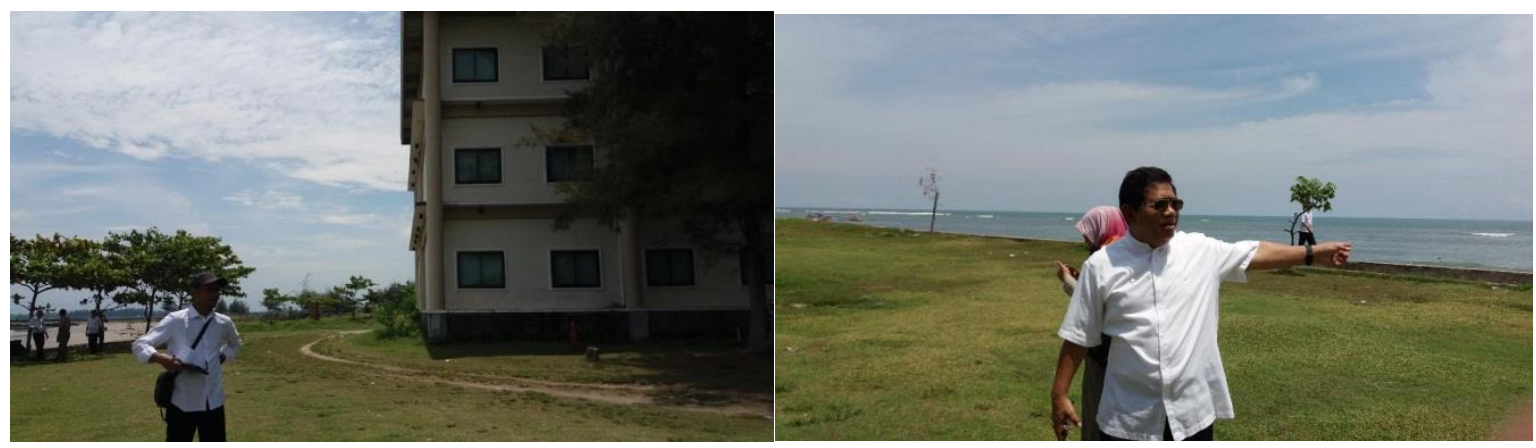

Sumber : Dokumen Penelitian

Gambar 43. Tanah Timbul Kelurahan Malabero (mess Pemda)

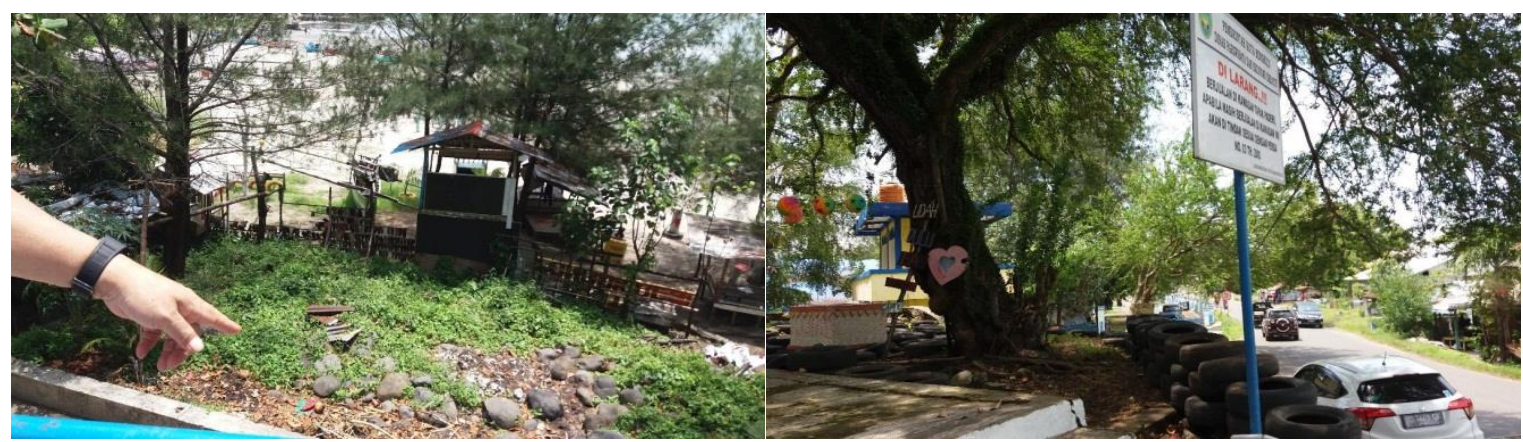

Sumber : Dokumen Penelitian

Gambar 44. Tanah Timbul di Pantai Jakat

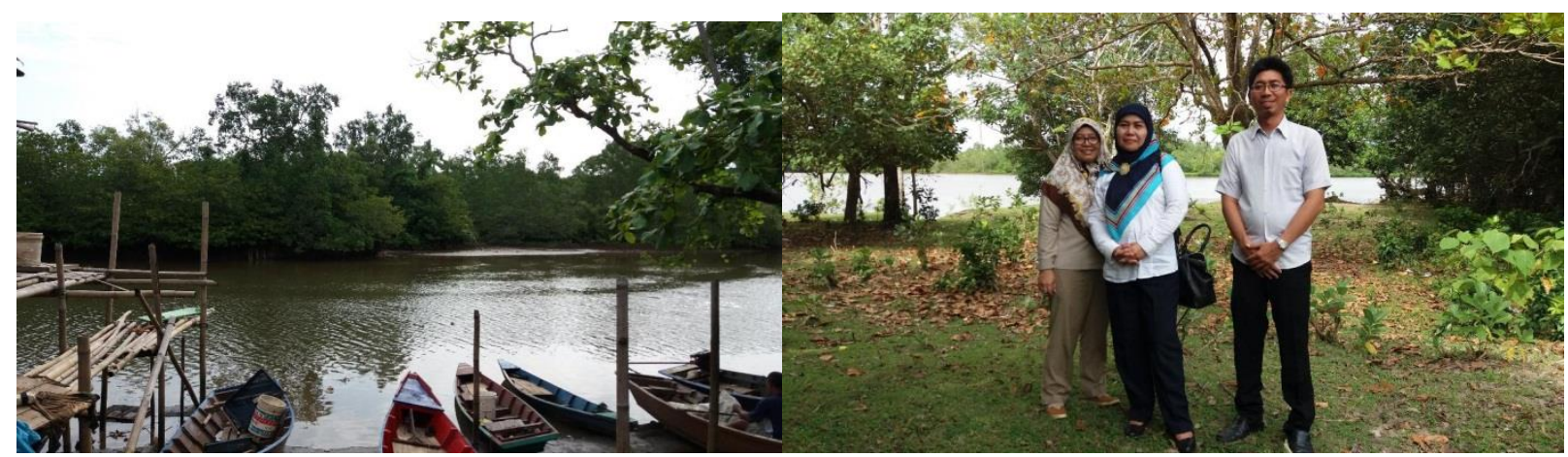

Sumber : Dokumen Penelitian

Gambar 45. Tanah Timbul di Kelurahan Kandang dan Muara Dua (masuk TWA) 


\subsubsection{Lokasi Tanah Timbul di Bengkulu Utara}

Tanah timbul di Kabupaten Bengkulu Utara terindikasi berada di Kecamatan Putri Hijau Desa Pasar Sebelat, Daerah Aliran Sungai Seblat, yang berada di tengah sungai, semacam timbunan batu, lokasinya dekat jalan utama dan tidak termasuk kawasan hutan.

Secara fisik lokasi diidentifikasi berupa daratan yang berada ditengah aliran Sungai Sebelat yang berdasarkan data dari Kantor Pertanahan Kabupaten Bengkulu Utara seluas 25,18 hektar. Material penyusunnya menurut informasi berupa batu dan tanah.

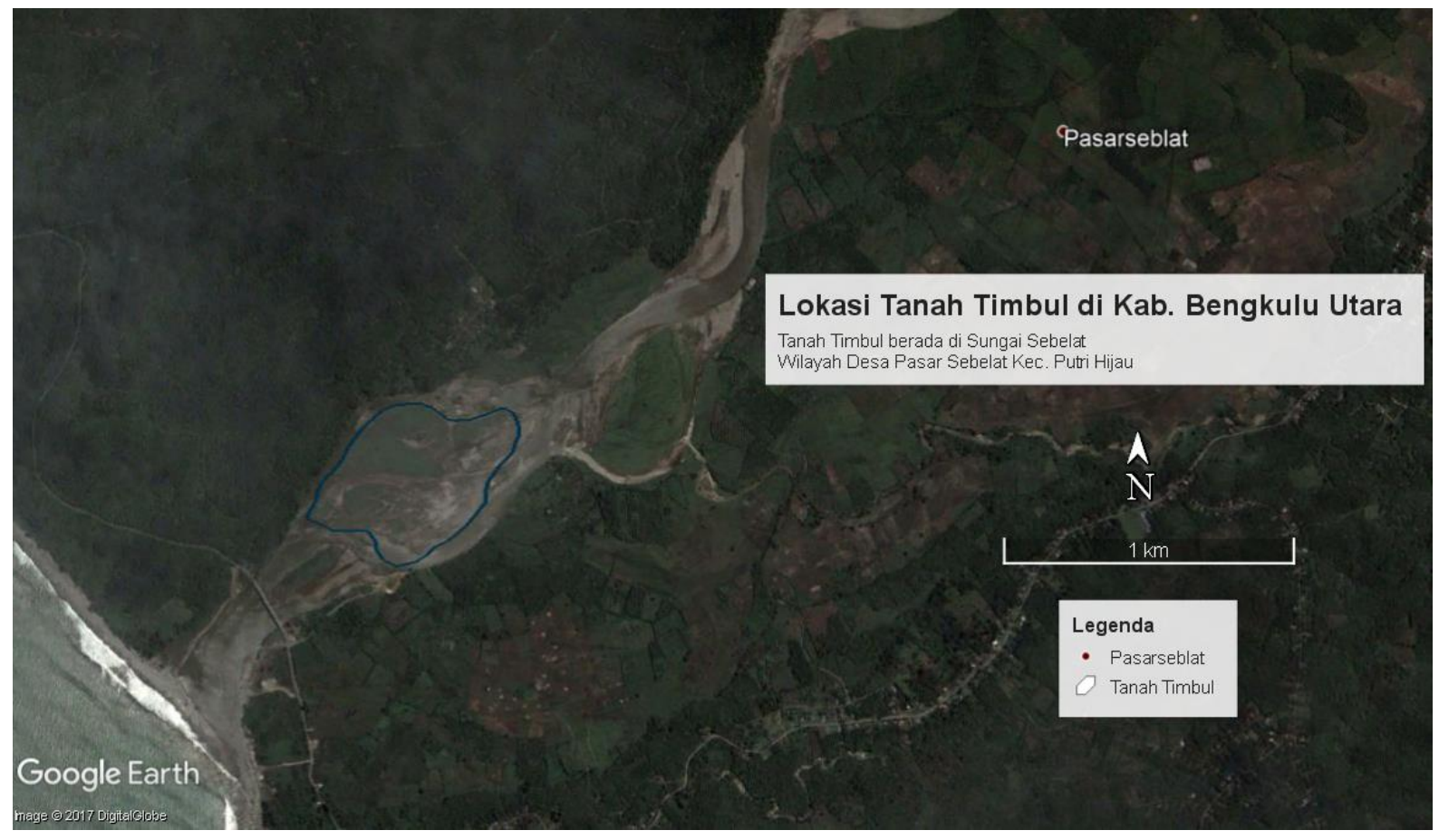

Sumber : Google earth (diolah)

Gambar 46. Tanah Timbul di Sungai Sebelat Kab.Bengkulu Utara

Proses terbentuknya daratan ini masih kurang jelas. Keberadaannya yang sudah cukup lama menyebabkan sulitnya mengidentifikasi sejarah pembentukannya. Perlu adanya penelitian khusus untuk mengetahuinya. Akan tetapi setidaknya terdapat dua kemungkinan mengenai keberadaan tanah ini sebagaimana yang disampaikan oleh Pegawai BKSDA Provinsi Bengkulu. Pertama tanah tersebut merupakan sedimentasi dari material yang dibawa oleh Sungai Sebelat seperti yang umum terjadi di wilayah lain. Kemungkinan kedua daratan tersebut terbentuk akibat aliran Sungai Sebelat yang bercabang akibat dari adanya aktivitas pengerukan material. Dari pengerukan ini aliran sungai menjadi terbelah sebelum menyatu kembali sehingga terjadi bentukan seperti pulau ditengah sungai. Pada kasus kedua ini maka lebih tepat jika disebut sebagai tanah hilang. 
Diperoleh data bahwa seluruh "pulau" tersebut dikuasai oleh satu orang yaitu Yurma Hamedi. Diatas tanah tersebut telah terbit dua buah sertipikat Hak Milik atas nama yang bersangkutan. Sertipikat pertama terbit pada tahun 2010 dengan nomor hak M 00447 seluas lebih kurang 2 hektar. Letak bidang tanah ini berada di area pinggiran daratan tanah timbul. Tidak banyak informasi lain yang bisa diambil tentang bidang tanah ini. Sertipikat kedua terbit tahun 2017 masih atas nama Yurman Hamedi dengan nomor Hak M 00207 dan luas bidang 49.000 meter persegi. Letak bidang tanah ini berada tepat ditengah daratan seperti yang bisa dilihat pada gambar dibawah ini. Kedua sertipikat tersebut diterbitkan dengan peruntukan tanah sebagai tanah pertanian atau perkebunan.

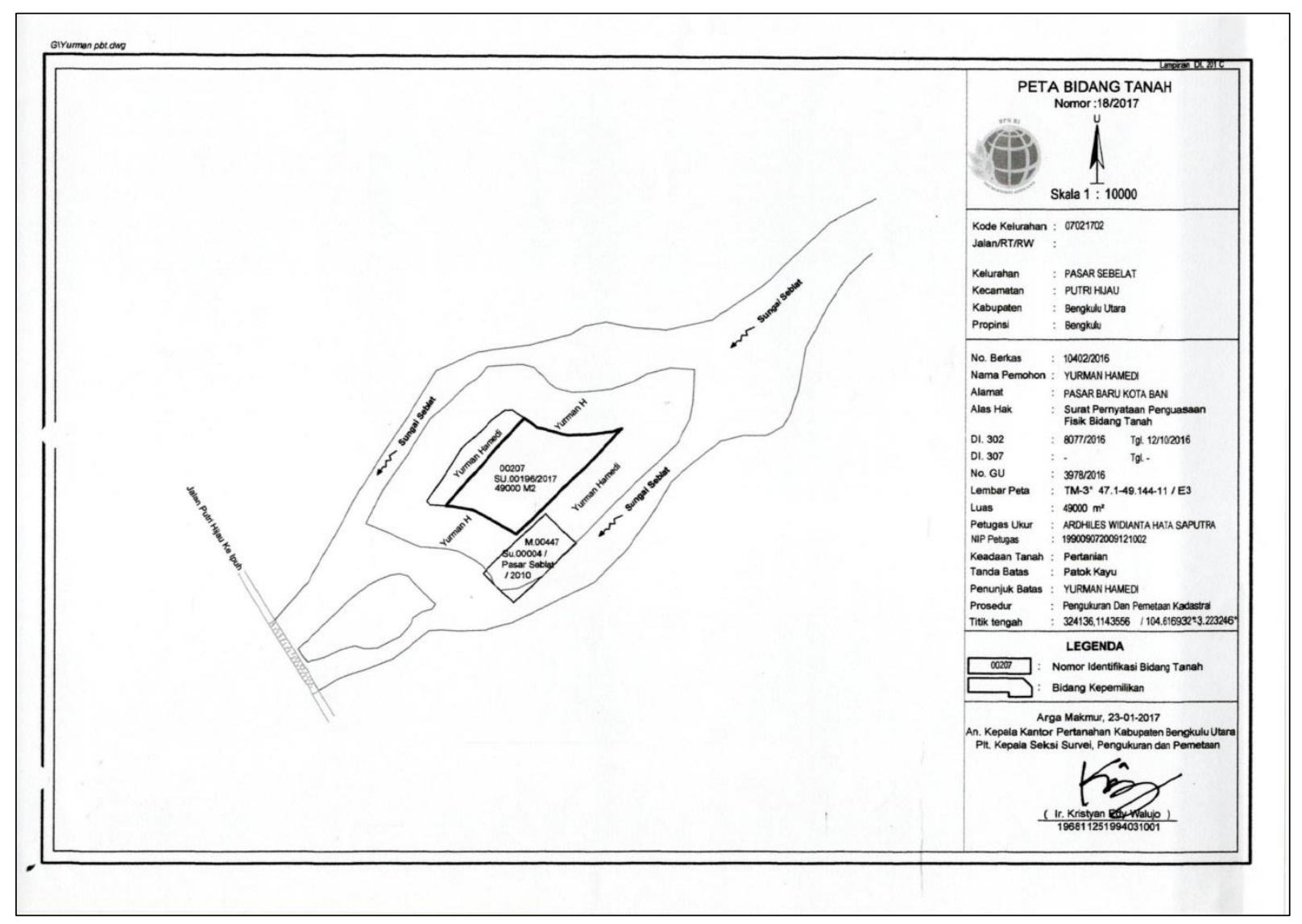

Sumber : Kantor Pertanahan kabupaten Bengkulu Utara

Gambar 47. Peta Bidang Tanah An. Yurman Hamedi

Pihak Kantor Pertanahan Kabupaten Bengkulu Utara melalui Kepala Seksi Penataan dan Pengaturan Pertanahan menjelaskan perihal penerbitan sertipikat kedua tersebut telah melalui serangkaian prosedur yang ditetapkan. Ditambahkan lagi, bahwasanya penerbitan sertpikat kedua dilakukan lebih berhati-hati untuk meminimalisir masalah yang kemungkinan timbul di masa depan. Untuk itu pihak Kantor Pertanahan Kabupaten Bengkulu Utara terlebih dahulu berkoordinasi dan meminta surat rekomendasi dari instansi terkait seperti dari Dinas Lingkungan Hidup Kabupaten bengkulu Utara dan BKSDA Provinsi Bengkulu. Setelah kedua 
rekomendasi tersebut diperoleh maka Kantor Pertanahan bisa melanjutkan proses permohonan hak untuk bidang tanah tersebut.

\subsection{Proses Terjadinya Tanah Timbul}

Tanah di wilayah pantai telah tempati oleh masyarakat dalam jangka waktu yang lama dan bahkan ada yang telah dihuni atau bermukim di wilayah tersebut secara turun temurun. Penguasaan secara turun temurun tersebut bersangkut paut dengan penguasaan wilayah pesisir oleh masyarakat adat yang kemudian diakui dalam undang-undang.

Dalam pertumbuhan tanah timbul, okupasi lahan oleh masyarakat belum tentu menunggu sampai benar-benar ada wujud "tanah". Begitu tanah itu muncul kemudian dimulai pengolahannya menjadi tanah pertanian yang baik, okupasi masyarakat di atas tanah itu biasanya sudah mantap. Lahan di kawasan pantai yang tidak dibebani hak milik, dikuasai oleh Negara dan digunakan sesuai peruntukan/fungsinya untuk kemakmuran rakyat.

Data dan informasi mengenai proses pembentukan tanah timbul sangat minim, setiap daerah dimana terdapat lokasi tanah timbul tidak mempunyai data resmi kapan mulai terbentuknya tanah timbul. Seperti di Kabupaten Tulungagung, menurut informasi daerah ini awalnya merupakan daerah yang tertutup dari akses. Baru mulai berkembang pada sekitar tahun 1998 saat maraknya penjarahan hutan. Pembangunan Jalan Lintas Selatan Pulau Jawa yang melintas di sekitar area pantai semakin membuka akses khususnya ke Pantai Gemah dan sekitarnya. Dari sini masyarakat mulai banyak datang ke lokasi karena memiliki panorama yang indah. Dengan mulai banyaknya pengunjung sebagian masyarakat sekitar yang melihat peluang usaha mulai mendirikan bangunan-bangunan non permanen yang diperuntukan untuk usaha. Semakin lama tingkat okupasi, terutama di Pantai Gemah semakin meningkat. Sementara di lokasi sebelahnya yaitu Pantai Bayem masyarakat memanfaatkan lahan untuk tambak.

Tanah timbul di Kota Cirebon terbentuk secara alami dari sedimentasi di area pantai secara terus menerus, dan dipercepat dengan adanya upaya pengurugan laut dangkal dengan sampah hingga menjadi tanah yang stabil. Secara perlahan-lahan menjadi tambak, dan ketika penduduk semakin padat akhirnya berkembang menjadi perumahan yang cukup padat. Di sisi utara terlihat adanya kemunduran pantai sedangkan di bagian tengah dan disisi selatan terlihat adanya penambahan pantai. Kemunduran di pantai kesenden diperkirakan karena abrasi (pengikisan) pantai. Permasalahan abrasi ditanggulangi dengan dibangunnya pemecah gelombang (break water) tahun 2009. Setahun setelah pembangunan break water , di kawasan ini telah terbentuk sedimen seluas kurang lebih 30 hektar. Sebaliknya di bagian tengah dan sisi selatan terjadi akresi karena adanya proses pengendapan, dari material endapan yang dibawa oleh sungai maupun endapan laut. Garis pantai yang maju ke arah laut, terutama di daerah yang sedimentasinya cukup tinggi, kemudian membentuk lahan daratan (tanah timbul). ${ }^{30}$

Bertambahnya luas wilayah Kota Cirebon yang berupa tanah timbul, ternyata dinilai menguntungkan. Keberadaan tanah timbul itu justru dimanfaatkan warga untuk mendirikan permukiman liar dan tambak. Pemanfaatan tanah timbul oleh warga dinilai memperbesar

\footnotetext{
${ }^{30} \mathrm{Nia}$ Noorrahmah, Reza Munawwir, Frans Almarta, Tanah Timbul di Kota Cirebon, Peluang dan Tantangan, Magister Perencanaan wilayah dan Kota, SAPPK ITB, 2014.
} 
terjadinya sengketa pertanahan, dengan regulasi yang jelas status tanah timbul bisa menjadi milik pemerintah kota sehingga di atas tanah timbul tersebut bisa dilakukan untuk berbagai keperluan yang bermanfaat seperti kawasan tambak, hutan mangrove, rumah penduduk atau bahkan untuk kawasan wisata.

Adapun di kabupaten Indramayu, informasi dari masyarakat yang menetap di area tanah timbul bahwa tanah timbul sudah ada sejak lama, disebabkan adanya pendangkalan air laut yang mencapai kedalaman satu meter, ketika mengalami sendimentasi warga sekitar menambah ketinggian tanah sehingga diklaim miliknya. Proses sedimentasi yang demikian kuat, khususnya di muara-muara sungai, mengakibatkan kawasan ini mengalami akrasi yang cukup cepat dan membentuk garis-garis pantai yang baru. Pola arus sejajar garis pantai (longshore current) dan pola arus laut (offshore current) mengakibatkan material sedimen terendapkan di sekitar garis pantai dan muara sungai, yang menimbulkan bertambahnya daratan, perubahan garis pantai dan tanah timbul.

Terjadinya tanah timbul di kota Bengkulu diindikasikan terjadi karena adanya sedimentasi. Ada indikasi tanah timbul (aanslibbing) terjadi di Pantai Berkas, Sumur Meleleh dan Malabero dikarenakan pembuangan limbah pengerukan Pelabuhan Pulau Baai, Penebangan hutan pantai dan mangrove untuk pembuatan jalan dari Pulau Baai, Pantai Panjang hingga Tapak Padri hingga pengambilan pasir pantai di sekitar sungai hitam, (Bengkulu menuju Kota pariwisata oleh Prof Urip Santoso tahun 2006) Pembentukan tanah timbul secara alamiah terjadi dalam kurun waktu yang panjang, puluhan tahun sampai mencapai titik kestabilan. Disamping itu, pembangunan Pelabuhan Pulau Baai juga mempercepat terjadi sedimentasi. Pulau Baai sebelum dibangun merupakan suatu lagun atau kolam yang terbentuk oleh lidah pasir yang membujur dari arah selatan ke utara. Lidah pasir ini oleh angkutan pasir pantai (littoral sand drift) yang berasal dari sebelah hulu (updrift) Tanjung kerbau, Tanjung kerbau itu sendiri merupakan terumbu koral yang asalnya terlepas dari pantai, keberadaan mulamula berbentuk tombolo, kemudian tombolo tumbuh dan menyatu dengan terumbu koral, sehingga arus pasir melewati terumbu koral tersebut dan membentuk endapan berupa lidah pasir di pulau Baai, kolam yang terbentuk oleh lidah pasir merupakan kolam yang ideal untuk dijadikan kolam pelabuhan karena terlindung dari gelombang dan berukuran luas. Untuk itu harus ada alur masuk yaitu dengan menembus lidah pasir dan membangun pemecah gelombang ditempat masuk. Proyek pelabuhan samudera Pulau Baai secara fisik mulai dikerjakan tahun anggaran 1980/1981. Pelabuhan Pulau Baai merupakan pelabuhan semi alam yaitu suatu pelabuhan yang terlindungi oleh lidah pantai dan perlindungan buatan hanya pada alur masuk, pembangunan pelabuhan ini memanfaatkan teluk yang terlindung oleh lidah pasir untu kolam pelabuhan. Pengerukan dan pemotongan dilakukan pada lidah pasir untuk membentuk saluran sebagai jalan masuk/ keluar kapal. ${ }^{31}$

Dari hasil pengumpulan data diperoleh tiga karakteristik proses terjadinya tanah timbul, yaitu :

a) Tanah timbul terjadi karena adanya sedimentasi

b) Tanah timbul yang terjadi karena usaha manusia dengan mempercepat proses sedimentasi dengan penanaman mangrove atau tiang pancang (oloran)

31 Yunisa Indasari, Analisis Yuridis Hak Penguasaan Atas Tanah Timbul Berdasarkan UUPA dan RTRW di Kecamatan Teluk Segara Kota Bengkulu, 2014. 
c) Tanah timbul terjadi karena pembangunan break water (pemecah gelombang) untuk mengatasi abrasi, yang justru menambah sedimen di sisi lain.

\subsection{Penguasaan dan Penggunaan Tanah di Lokasi Tanah Timbul}

Berdasarkan data yang diperoleh dari WP3WT, Kantor Wilayah BPN, Kantor Pertanahan dan Pemerintah daerah wilayah penelitian diperoleh gambaran penguasaan, penggunaan dan pemanfaatan tanah timbul sebagaimana terdapat dalam Tabel Matriks Penguasaan, Penggunaan dan Pemanfaatan Tanah timbul.

Luasan tanah timbul yang terbesar terdapat di Kabupaten Cilacap sebesar 2.091 ha, kedua Kabupaten Indramayu sebesar 1.935,39 ha dan Kabupaten Cirebon seluas 1.138 ha. Tanah timbul dengan luasan terendah adalah Kabupaten Bengkulu Utara seluas 25,18 ha, kedua Kabupaten Mojokerto seluas 39 ha dan Kota Bengkulu seluas 46,26 ha. Untuk penguasaan tanahnya, tanah timbul di Kota dan Kabupaten Cirebon mayoritas sudah bersertipikat. Yang belum bersertipikat ditemukan di Kabupaten Tulungagung, Kabupaten Pasuruan dan Kabupaten Kebumen, karena lokasinya masuk dalam kawasan hutan. Untuk tanah timbul yang hilang ditemukan di Kabupaten Tangerang, Desa Mauk seluas 109 ha.

Untuk penggunaan dan pemanfaatan tanah timbul mayoritas digunakan untuk tambak, kedua untuk perumahan (diwilayah Kota Cirebon, Kabupaten Cilacap dan kabupaten Indramayu), ketiga untuk industry (Kabupaten Indramayu), kemudian untuk pertanian (Kabupaten Cilacap dan Kota Cirebon), dan sebagai tempat wisata (Kabupaten Tulungagung dan Kota Bengkulu). 
Tabel 45. MATRIKS HASIL PENGUASAAN DAN PENGGUNAAN TANAH TIMBUL

Lokasi Prov. Jabar,Jateng, Banten,Jatim, Bengkulu

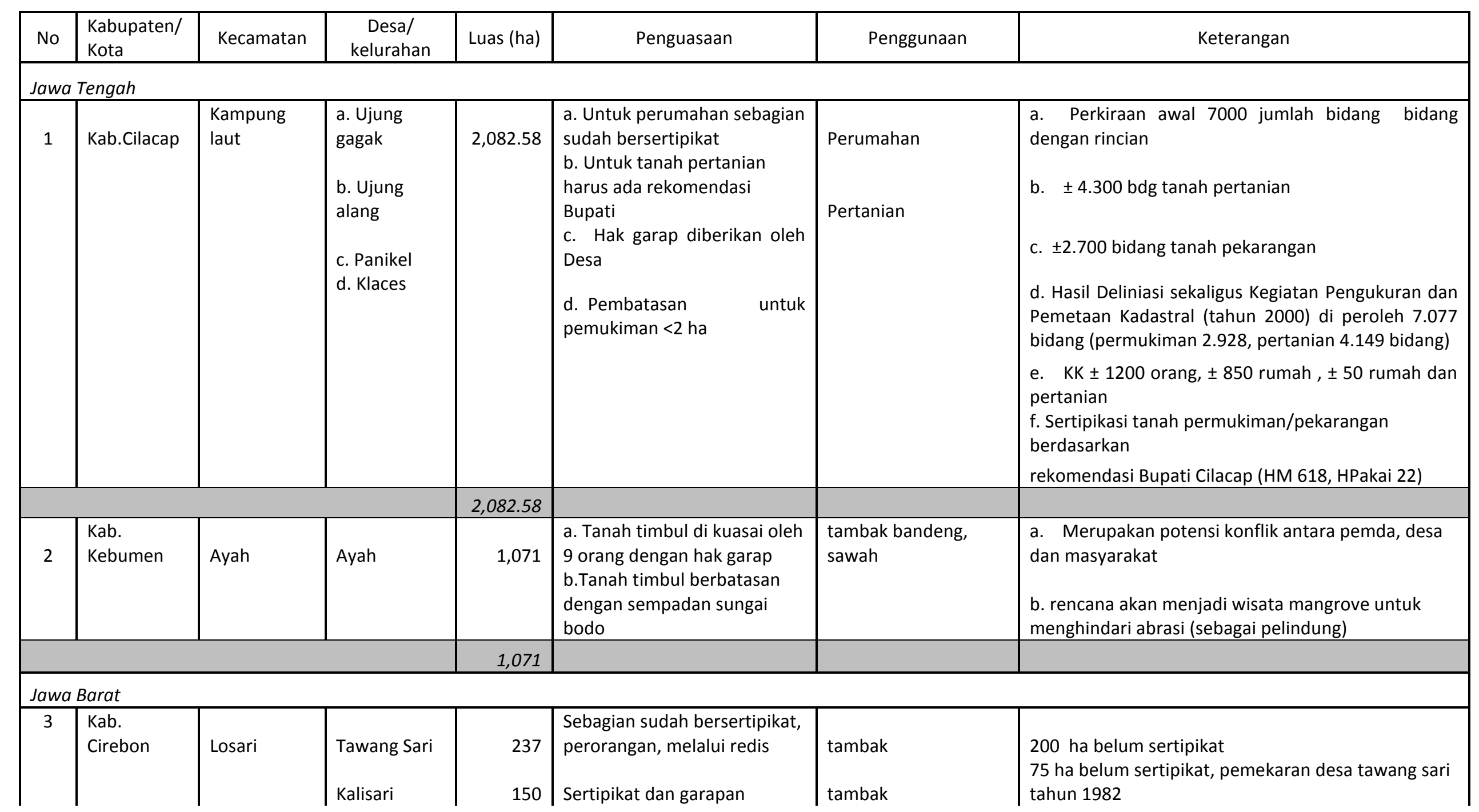




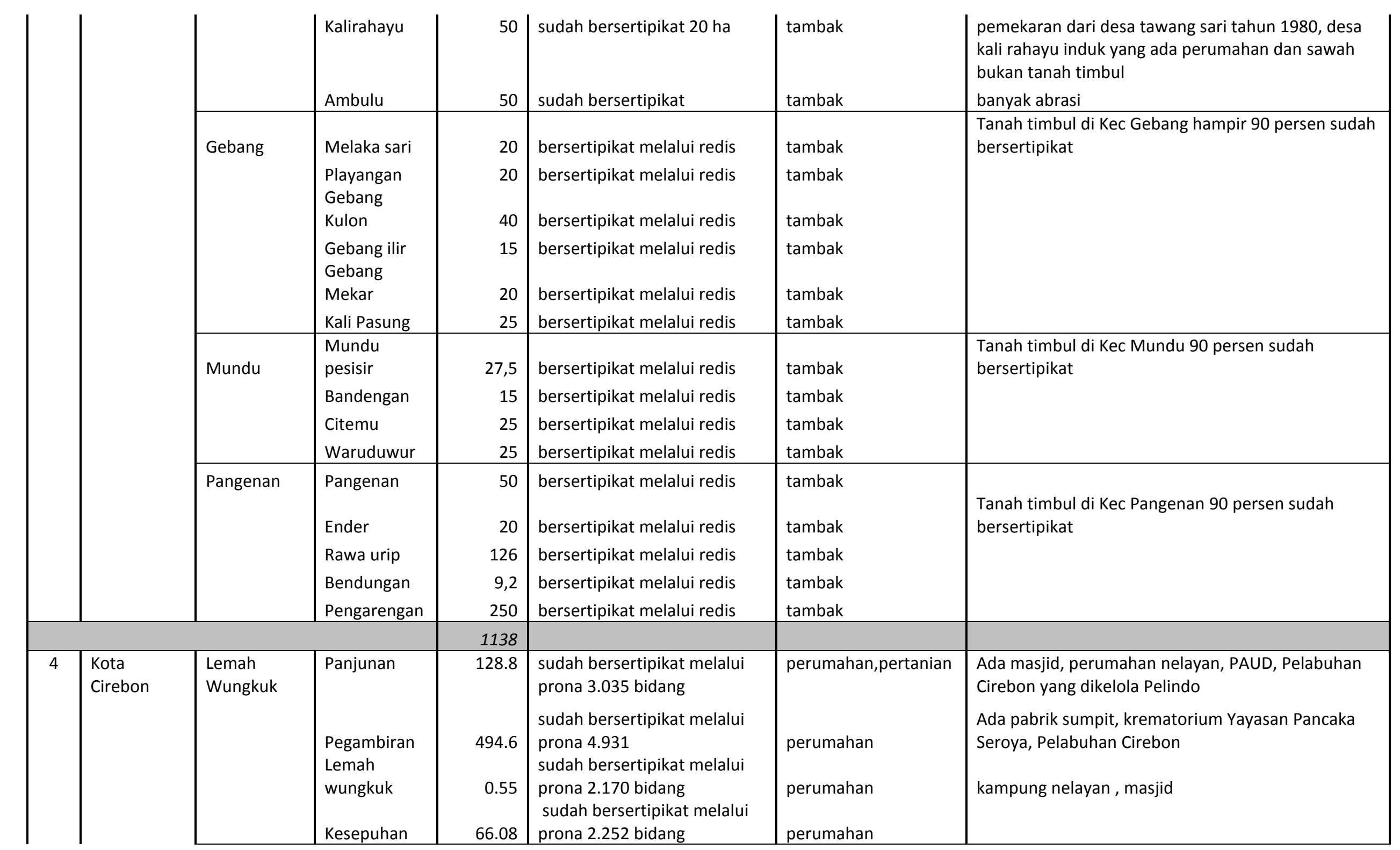




\begin{tabular}{|c|c|c|c|c|c|c|c|}
\hline & & Kejaksan & $\begin{array}{l}\text { Kesenden } \\
\text { Kebon waru }\end{array}$ & $\begin{array}{r}125 \\
72.31 \\
\end{array}$ & $\begin{array}{l}\text { sudahbersertipikat } 3.262 \\
\text { bidang,program nelayan } \\
\text { MOU dengan KKP } \\
\text { sudah bersertipikat } 1.888 \\
\text { bidang }\end{array}$ & \begin{tabular}{|l} 
perumahan \\
Jalakesendan 100 \\
bidang untuk rumah \\
subsidi $72 \mathrm{~m} 2$
\end{tabular} & $\begin{array}{l}\text { Rekomendasi walkot } 1994 \text { tidak boleh ada kegiatan } \\
\text { di tn timbul seb selatan jalan pantai }\end{array}$ \\
\hline & & & & 887.34 & & & \\
\hline \multirow[t]{6}{*}{5} & \multirow[t]{6}{*}{$\begin{array}{l}\text { Kab. } \\
\text { Indramayu }\end{array}$} & $\begin{array}{l}\text { Kandang } \\
\text { haur }\end{array}$ & $\begin{array}{l}\text { Ilir } \\
\text { Pareangirang }\end{array}$ & $\begin{array}{r}68.34 \\
121.32 \\
\end{array}$ & & & \\
\hline & & Krangkeng & $\begin{array}{l}\text { Kalianyar } \\
\text { Krangkeng } \\
\text { Luwung gesik }\end{array}$ & $\begin{array}{r}87.9 \\
15.56 \\
64.64 \\
\end{array}$ & & & \\
\hline & & Indramayu & $\begin{array}{l}\text { Singajaya } \\
\text { Singaraja } \\
\text { Karangsong } \\
\text { Pabean udik } \\
\end{array}$ & $\begin{array}{r}15.26 \\
6.12 \\
6.09 \\
\\
154.18 \\
\end{array}$ & sertipikat tahun 1995 & $\begin{array}{l}\text { perumahan,tambak, } \mathrm{T} \\
\mathrm{PI} \text {,pelabuhan }\end{array}$ & $\begin{array}{l}\text { Konservasi } \\
\text { Konservasi }\end{array}$ \\
\hline & & Balongan & $\begin{array}{l}\text { Majakerta } \\
\text { Balongan } \\
\end{array}$ & $\begin{array}{l}3.26 \\
3.48 \\
\end{array}$ & & $\begin{array}{l}\text { industri } \\
\text { industri }\end{array}$ & Dipakai industri balongan \\
\hline & & Pasekan & $\begin{array}{l}\text { Brondong } \\
\text { Pabean ilir } \\
\end{array}$ & $\begin{array}{r}117.97 \\
411.1 \\
\end{array}$ & & & \\
\hline & & Cantigi & \begin{tabular}{|l} 
Lamran \\
Tarung \\
Cemara
\end{tabular} & $\begin{array}{l}480.14 \\
380.03\end{array}$ & & Daerah konservasi & \\
\hline & & & & 1935.39 & & & \\
\hline \multicolumn{8}{|c|}{ Banten } \\
\hline \multirow[t]{3}{*}{6} & \multirow[t]{3}{*}{ Kab.Serang } & Tirtayasa & Tengkura & 90 & $\begin{array}{l}\text { bersertipikat redistribusi } \\
\text { tahun } 2012\end{array}$ & tambak & 100 ha bersertipikat, 90 ha yang belum sertipikat \\
\hline & & Tanara & $\begin{array}{l}\text { Tenjo Ayu } \\
\text { Pedaleman }\end{array}$ & $\begin{array}{l}200 \\
100\end{array}$ & $\begin{array}{l}\text { sertipikat melalui redis tahun } \\
2012 \\
\text { belum diidentifikasi }\end{array}$ & tambak & dari daratan ke laut ada $\pm 4 \mathrm{~km}$ \\
\hline & & Pontang & Suka Jaya & 100 & belum ada hak & tambak & Rencana KT kerjasama dengan Dinas Kelautan \\
\hline
\end{tabular}




\begin{tabular}{|c|c|c|c|c|c|c|c|}
\hline & & & & 490 & & & \\
\hline \multirow[t]{5}{*}{7} & \multirow[t]{5}{*}{$\begin{array}{l}\text { Kab. } \\
\text { Tangerang }\end{array}$} & Mauk & $\begin{array}{l}\text { Ketapang } \\
\text { Tanjung } \\
\text { Anom } \\
\text { Mauk Barat }\end{array}$ & $\begin{array}{r}50 \\
50 \\
9\end{array}$ & & & $\begin{array}{l}\text { Terkena abrasi } \\
\text { Terkena abrasi } \\
\text { Terkena abrasi }\end{array}$ \\
\hline & & Kronjo & $\begin{array}{l}\text { Pagedanga } \\
\text { n llir }\end{array}$ & 40 & & & abrasi, timbul di desa Pagedangan Ilir \\
\hline & & Pakuhaji & $\begin{array}{l}\text { Surya } \\
\text { Bahari } \\
\text { Kramat } \\
\text { Kohod }\end{array}$ & $\begin{array}{l}40 \\
10 \\
50\end{array}$ & $\begin{array}{l}\text { sertipikat redis } \\
\text { sertipikat redis }\end{array}$ & $\begin{array}{l}\text { tambak } \\
\text { tambak }\end{array}$ & \\
\hline & & Teluk Naga & $\begin{array}{l}\text { Tanjung } \\
\text { Burung } \\
\text { Tanjung } \\
\text { Pasir } \\
\end{array}$ & $\begin{array}{r}12.79 \\
34.26 \\
\end{array}$ & $\begin{array}{l}\text { surat garapan dari kades } \\
\text { tahun 1982, per } 6 \text { ha setiap } \\
\text { surat } \\
\text { belum sertipikat, } \\
\text { kemungkinan ada SK } \\
\text { Kehutanan } \\
\end{array}$ & $\begin{array}{l}\text { tambak } \\
\text { tambak dan rumah }\end{array}$ & $\begin{array}{l}\text { Kemungkinan } \pm 400 \text { ha perlu pendataan kembali, } \\
\text { ada SPPT berarti diakui sebagai hak milik adat } \\
\text { oleh Dinas Pajak melalui sismiop }\end{array}$ \\
\hline & & Kosambi & $\begin{array}{l}\text { Salembaran } \\
\text { Jaya } \\
\text { Kosambi } \\
\text { Barat } \\
\text { Kosambi } \\
\text { Timur } \\
\text { Dadap } \\
\end{array}$ & $\begin{array}{r}10.51 \\
0.81 \\
0.12 \\
0.57 \\
\end{array}$ & & & $\begin{array}{l}\text { Kosambi pemekaran dari Teluk Naga } \\
\text { tata Ruang untuk pertanian dan tambak }\end{array}$ \\
\hline & & & & 308.06 & & & \\
\hline \multicolumn{8}{|c|}{ Jawa Timur } \\
\hline 8 & $\begin{array}{l}\text { Kota } \\
\text { Pasuruan }\end{array}$ & Bugulkidul & $\begin{array}{l}\text { Blandongan } \\
\text { Kepel }\end{array}$ & $\begin{array}{l}400 \\
150\end{array}$ & $\begin{array}{l}\text { sudah ada yang bersetipikat } 5 \\
\text { bidang masing } 2 \text { ha } \\
\text { surat garapan dari lurah, } \\
\text { sudah ada pbb mulai tahun } \\
2000 \text { an }\end{array}$ & $\begin{array}{l}\text { tambak } \\
\text { tambak ikan, tambak } \\
\text { garam }\end{array}$ & $\begin{array}{l}\text { jarak dari pantai sepanjang } 2 \mathrm{~km} \text {, ada mangrove } \\
\text { berbatasan selat madura } \\
\text { masuk dalam LP2B }\end{array}$ \\
\hline & & & & 550 & & & \\
\hline 9 & $\begin{array}{l}\text { Kab. } \\
\text { Pasuruan }\end{array}$ & $\begin{array}{l}\text { Rejoso } \\
\text { Kraton }\end{array}$ & $\begin{array}{l}\text { Jarangan } \\
\text { Semare }\end{array}$ & $\begin{array}{r}20.74 \\
39.2\end{array}$ & $\begin{array}{l}\text { surat garapan } \\
\text { surat garapan }\end{array}$ & $\begin{array}{l}\text { tambak, rumah } \\
\text { tambak, rumah }\end{array}$ & $\begin{array}{l}\text { masuk konservasi, bayar PBB sejak } 1978 \text { masuk } \\
\text { letter c desa } \\
\text { masuk konservasi, bayar PBB sejak } 1978 \text { masuk }\end{array}$ \\
\hline
\end{tabular}




\begin{tabular}{|c|c|c|c|c|c|c|c|}
\hline & & & & & & & letter c desa \\
\hline \multirow[b]{2}{*}{10} & & & & 59.94 & & & \\
\hline & $\begin{array}{l}\text { Kab. } \\
\text { Mojokerto }\end{array}$ & Gedeg & $\begin{array}{l}\text { Kemantren } \\
\text { Gembonga } \\
\mathrm{n} \\
\text { Gedeg } \\
\text { Gembolker } \\
\text { ep } \\
\text { Ngareskidul } \\
\text { Pagerluyun } \\
\text { g } \\
\text { Terusan } \\
\end{array}$ & $\begin{array}{r}14,04 \\
6,69 \\
1,45 \\
5,46 \\
1,14 \\
1,74 \\
8,76 \\
\end{array}$ & $\begin{array}{l}\text { garapan, ada letter c, } \\
\text { sertipikat } \\
\text { dikuasai oleh } 10 \text { orang }\end{array}$ & $\begin{array}{l}\text { ladang, rumah } \\
\text { kebun }\end{array}$ & $\begin{array}{l}\text { ada } 3 \text { bangunan, dulu sering banjir sehingga } \\
\text { masyarakat pindah keseberang } \\
\text { masuk sempadan, 50m dari tepi sungai, DAS } \\
\text { Brantas }\end{array}$ \\
\hline \multirow[b]{2}{*}{11} & & & & 39 & & & \\
\hline & $\begin{array}{l}\text { Kab.Tulung } \\
\text { Agung }\end{array}$ & $\begin{array}{l}\text { Besuki } \\
\text { Pucanglaban } \\
\text { Tanggunggu } \\
\text { ng } \\
\text { Kalidawir }\end{array}$ & $\begin{array}{l}\text { Besuki } \\
\text { Kebo ireng } \\
\text { Pucanglaba } \\
\mathrm{n} \\
\text { Tanggungg } \\
\text { ung } \\
\text { Kalibatur }\end{array}$ & $\begin{array}{r}16.11 \\
32.58 \\
18.48 \\
\\
5.51 \\
16.95 \\
\end{array}$ & $\begin{array}{l}\text { tepi pantai gemah dan } \\
\text { bayem, disewa masyarakat ke } \\
\text { Pemda }\end{array}$ & warung, wisata & dimohon HPL oleh Pemda \\
\hline \multirow[b]{2}{*}{12} & & & & 89.63 & & & \\
\hline & $\begin{array}{l}\text { Kab. } \\
\text { Sidoarjo }\end{array}$ & $\begin{array}{l}\text { Jabon } \\
\text { Sedati }\end{array}$ & $\begin{array}{l}\text { Kupang } \\
\text { Kedungpan } \\
\text { dan } \\
\text { Kalanganya } \\
r\end{array}$ & $\begin{array}{r}5,98 \\
839,36 \\
46.79\end{array}$ & tanah garapan & & endapan lumpur lapindo menjadi Pulau Dem \\
\hline & & & & 892.13 & & & \\
\hline \multicolumn{8}{|c|}{ Bengkulu } \\
\hline 13 & $\begin{array}{l}\text { Kota } \\
\text { Bengkulu }\end{array}$ & Teluk Segara & Berkas & 6.27 & $\begin{array}{l}\text { masih terjadi perebutan } \\
\text { penguasaan antar Pemkot }\end{array}$ & $\begin{array}{l}\text { tempat usaha, wisata, } \\
\text { aset pemerintah, rumah }\end{array}$ & \\
\hline
\end{tabular}




\begin{tabular}{|c|c|c|c|c|c|c|c|}
\hline & & & $\begin{array}{l}\text { Bajak } \\
\text { Pondok } \\
\text { Besi } \\
\text { Kebon } \\
\text { Keling } \\
\text { Sumur } \\
\text { Meleleh } \\
\text { Tengah } \\
\text { Padang } \\
\text { Malabero }\end{array}$ & $\begin{array}{l}1.32 \\
1.95 \\
7.35 \\
5.25 \\
1.32 \\
1.97\end{array}$ & $\begin{array}{l}\text { Bengkulu dan Pemprov } \\
\text { Bengkulu }\end{array}$ & penduduk, & \\
\hline & & $\begin{array}{l}\text { Kampung } \\
\text { Melayu } \\
\text { Sungai Serut }\end{array}$ & $\begin{array}{l}\text { Kandang } \\
\text { Sumber } \\
\text { Jaya } \\
\text { Pasar } \\
\text { Bengkulu }\end{array}$ & $\begin{array}{r}4.61 \\
4.1 \\
12.12 \\
\end{array}$ & BKSDA & $\begin{array}{l}\text { semak belukar, } \\
\text { mangrove }\end{array}$ & Masuk dalam Taman Wisata Alam \\
\hline & & & & 46.26 & & & \\
\hline 14 & $\begin{array}{l}\text { Bengkulu } \\
\text { Utara }\end{array}$ & Putri Hijau & $\begin{array}{l}\text { Pasar } \\
\text { Sebelat }\end{array}$ & 25.18 & Yurman Hamedi & $\begin{array}{l}\text { indikasi pemanfaatan } \\
\text { tambang galian c }\end{array}$ & $\begin{array}{l}\text { sudah terbit } 2 \text { sertipikat an. Yurman Hamedi } \\
\text { masing-masing tahun } 2010(2 \mathrm{Ha}) \text { dan } 2017(5 \mathrm{Ha})\end{array}$ \\
\hline & & & & 25.18 & & & \\
\hline
\end{tabular}

Sumber: Data WP3WT, Kantor Pertanahan Sampel, Data Pemerintah Daerah Kabupaten Tulungagung, Data Pemerintah Daerah Kabupaten Indramayu

Berdasarkan matriks di atas' menunjukkan luasan tanah timbul terluas ada di Kabupaten Cilacap sebesar 2.082,58 ha, kedua adalah tanah timbul di Kabupaten Indramayu seluas 1.935,39 ha dan ketiga Kabupaten Cirebon seluas 1.138 ha. Sedangkan luasan tanah timbul yang terkecil ditemukan di Bengkulu Utara, Kabupaten Mojokerto dan Kota Bengkulu.

Adapun penguasaan tanah timbul, untuk Kabupaten Cirebon mayoritas sudah bersertipikat, demikian juga Kota Cirebon, Kabupaten Cilacap untuk tanah perumahan, sedangkan di Kabupaten Kebumen dan Tulungagung tidak bisa disertipikatkan karena masuk dalam kawasan hutan. 


\subsection{Pemberian Hak Atas Tanah Timbul}

Tanah adalah sumberdaya alam yang sifatnya tetap, tidak bertambah. Namun dengan adanya tanah timbul menjadi suatu berkah dan anugrah bagi masyarakat terutama yang berada di wilayah pesisir. Adanya tanah baru ini dapat dimanfaatkan baik sebagai tempat untuk mendapatkan mata pencaharian maupun sebagai tempat untuk bermukim. Fenomena tanah timbul ini harus disikapi dalam konteks bagaimana tanah baru ini dapat meningkatkan kesejahteraan masyarakat dan sekaligus tidak merusak lingkungan sekitar.

Berbagai pendapat mewarnai fenomena tanah timbul karena sifat dari tanah timbul itu sendiri cenderung unstable, artinya tanah timbul ada kemungkinan hilang setelah beberapa tahun. Sebagai contoh di kabupaten Serang, di desa Tenjo Ayu I, desa Lontar dan desa Legok, tanah timbul sudah bersertipikat tapi kemudian tanahnya hilang, diantara tanah yang sudah bersertipikat itu ada yang dijaminkan sebagai hak tanggungan. Atas dasar kejadian alam ini, maka ada pemikiran untuk memberikan hak yang sifatnya sementara, berarti tanah timbul tidak boleh menjadi property right. ${ }^{32}$ Dengan demikian pemanfaatan tanah timbul digunakan untuk kepentingan umum/bersama, dikelola oleh desa dan tidak dapat dipindah tangankan (non tradable).

Pendapat yang berbeda mengenai status penguasaan tanah pantai, ditinjau dari perspektif teori penguasaan dan kepemilikan sumber daya alam. mengemukakan bahwa:

Penguasaan dan pemilikan mencerminkan adanya hubungan yang melekat pada sesuatu (benda) oleh seseorang atau badan hukum, namun sesungguhnya pengertiannya berbeda satu sama lain. Dalam konsep hukum, hubungan antara orang dengan benda merupakan hubungan yang disebut "hak". Makna dari sebutan itu adalah hak kepemilikan atas suatu benda tersebut hak milik atas benda itu atau dikenal sebagai property right, yang oleh Chambers diartikan bahwa "property rights are right to things". 33

Dasar hukum terkait dengan pemberian hak atas tanah dalam UUPA, Pasal 2 ayat (2) dikemukakan bahwa hak menguasai negara adalah memberikan kewenangan kepada negara untuk mengatur dan menyelenggarakan peruntukan, penggunaan, persediaan dan pemeliharaan bumi, air, dan ruang angkasa. Hak menguasai negara bukanlah berarti negara yang memiliki tanah, tetapi memberikan kewenangan kepada negara sebagai organisasi kekuasaan dari bangsa Indonesia pada tingkatan tertinggi untuk mengatur dan menyelenggarakan peruntukan, penggunaan, persediaan dan pemeliharaan bumi, air, dan ruang angkasa. Selain itu, negara juga memiliki kewenangan untuk menentukan dan mengatur hak-hak yang dapat dipunyai atas bumi, air, dan ruang angkasa serta menentukan dan mengatur hubungan-hubungan hukum antar orang-orang dan perbuatan-perbuatan hukum

32 Luky Adrianto, Tata Kelola Tanah Timbul Untuk Mewujudkan Kesejahteraan Masyarakat, FGD Penyusunan Rumusan Kebijakan Teknis Reklamasi dan Tanah Timbul di Kementerian Agraria dan Tata Ruang/Badan Pertanahan Nasional, 2017

33 Farida Patittingi, Hak Atas Tanah Pulau-Pulau Kecil, Disertasi, Program Pascasarjana Universitas Hasanuddin, Makassar, hal. 9, 2008. 
mengenai bumi, air dan ruang angkasa dengan tujuan untuk mencapai sebesar-besarnya kemakmuran rakyat dalam rangka mewujudkan masyarakat yang adil dan makmur.

Demikian pula ketentuan dalam Undang-Undang Nomor 27 tahun 2007 , memberikan penghormatan dan perlindungan terhadap masyarakat di wilayah pesisir sebagaimana dalam Pasal 61:

1) Pemerintah mengakui, menghormati, dan melindungi hak-hak Masyarakat Adat, Masyarakat Tradisional, dan Kearifan Lokal atas Wilayah Pesisir dan Pulau-Pulau Kecil yang telah dimanfaatkan secara turun-temurun.

2) Pengakuan hak-hak Masyarakat Adat, Masyarakat Tradisional, dan Kearifan Lokal sebagaimana dimaksud pada ayat (1) dijadikan acuan dalam Pengelolaan Wilayah Pesisir dan Pulau-Pulau Kecil yang berkelanjutan.

Berkaitan dengan hal tersbut, dalam Peraturan Pemerintah Nomor 16 Tahun 2004 tentang Penatagunaan Tanah, Pasal 3 dijelaskan bahwa tujuan penatagunaan tanah adalah:

a) Mengatur penguasaan, penggunaan dan pemanfaatan tanah bagi berbagai kebutuhan kegiatan pembangunan yang sesuai dengan Rencana Tata Ruang Wilayah;

b) Mewujudkan penguasaan, penggunaan dan pemanfaatan tanah agar sesuai dengan arahan fungsi kawasan dalam Rencana Tata Ruang Wilayah;

c) Mewujudkan tertib pertanahan yang meliputi penguasaan, penggunaan dan pemanfaatan tanah termasuk pemeliharaan tanah serta pengendalian pemanfaatan tanah;

d) Menjamin kepastian hukum untuk menguasai, menggunakan dan memanfaatkan tanah bagi masyarakat yang mempunyai hubungan hukum dengan tanah sesuai dengan Rencana Tata Ruang Wilayah yang telah ditetapkan.

Berdasarkan huruf $\mathrm{d}$ tersebut, maka tanah pantai pada hakikatnya dapat dimiliki atau dihaki oleh orang atau badan hukum. Kepemilikan dan penguasaan tanah pantai dan pemanfaatan wilayah pesisir ini tentunya harus memperhatikan dan disesuaikan dengan rencana tata ruang wilayah kabupaten/kota.

Pemberian hak tidak dapat diberikan, dalam hal merupakan :

a) Bangunan yang terletak di luar batas wilayah laut provinsi;

b) Instalasi eksplorasi dan atau eksploitasi minyak bumi, gas, pertambangan, panas bumi;

c) Instalasi kabel bawah laut, jaringan pipa dan jaringan transmisi lainnya;

d) Bangunan yang terapung. ${ }^{34}$

\subsubsection{Macam Hak Atas Tanah Yang Dapat Diberikan}

Wewenang pada hak menguasai dari negara sebagaimana tersebut dalam pasal 2 digunakan untuk mencapai sebesar-besar kemakmuran rakyat dalam arti kebangsaan, kesejahteraan, dan kemerdekaan dalam masyarakat dan negara hukum Indonesia yang

34 Pasal 7 Peraturan Menteri Agraria dan Tata Ruang/Badan Pertanahan Nasional Nomor 17 tahun 2016 tentang Penataan Pertanahan di Wilayah Pesisir dan Pulau-Pulau Kecil 
merdeka, berdaulat, adil dan makmur. Maka berdasarkan wewenang tersebut, negara dapat menentukan bermacam-macam hak atas tanah yang dapat diberikan dan dipunyai oleh orangorang, baik sendiri maupun bersama-sama serta badan hukum. Hak-hak atas tanah sebagaimana dimaksud merupakan hak untuk mempergunakan tanah yang bersangkutan (pasal 4 ayat 1 ).

Adapun macam-macam hak-hak atas tanah tersebut dapat dilihat dalam Pasal 16 ayat (1) UUPA, sebagai berikut:
a. Hak milik
b. Hak guna usaha
c. Hak guna bangunan
d. Hak pakai
e. Hak sewa,
f. Hak membuka tanah,
g. Hak memungut hasil hutan,
h. Hak-hak lain yang tidak termasuk dalam hak-hak tersebut diatas yang akan ditetapkan dengan undang-undang, serta hak-hak yang sifatnya sementara sebagai yang disebutkan dalam Pasal 53.

Hak atas tanah yang sifatnya sementara menurut Prof. Boedi Harsono, artinya pada suatu waktu hak-hak tersebut sebagai lembaga hokum tidak aka nada lagi, hak-hak yang dimaksud adalah Hak Gadai, hak Usaha Bagi hasil, Menumpang dan hak Sewa Untuk Pertanian (pasal 53 UUPA). ${ }^{35}$

Kemudian setiap warga negara indonesia mempunyai kesempatan yang sama untuk memperoleh hak atas tanah. Hal ini terdapat dalam ketentuan Pasal 9 ayat (2) UUPA :

" Tiap warga negara indonesia, baik pria maupun wanita mempunyai kesempatan yang sama untuk memperoleh suatu hak atas tanah serta untuk mendapatkan manfaat dan hasil bagi diri sendiri maupun keluarganya"

Berkaitan dengan macam hak atas tanah di atas dan Peraturan Menteri Agraria dan Tata Ruang/Badan Pertanahan Nasional Nomor 17 tahun 2016 tentang Penataan Pertanahan di Wilayah Pesisir dan Pulau-Pulau Kecil, dalam pasal 6 bahwa pemberian hak atas tanah di wilayah pesisir dilakukan berdasarkan peraturan perundang-undangan dan memenuhi syarat antara lain, peruntukannya sesuai dengan tata ruang wilayah provinsi/kabupaten/kota atau rencana zonasi wilayah, kemudian mendapatkan rekomendasi dari pemerintah provinsi/kabupaten/kota dalam hal belum diatur mengenai peruntukan tanah dalam RTRW.

Dengan demikian terhadap tanah timbul dimungkinkan untuk diberikan hak di bawah ini :

1) Hak milik, berdasarkan Pasal 20 UUPA adalah hak turun temurun, terkuat dan terpenuh yang dapat dipunyai orang atas tanah, dengan mengingat ketentuan dalam pasal 6.

2) Hak guna usaha adalah hak untuk mengusahakan tanah yang dikuasai langsung oleh Negara, dalam jangka waktu sebagaimana tersebut dalam pasal 29 , guna perusahaan

35 Boedi Harsoni, 2005, Hukum Agraria Indonesia : Sejarah Pembentukan Undang-Undang Pokok Agraria, Isi dan Pelaksanaannya, Penerbit Djambatan, hal 290. 
pertanian, perikanan atau peternakan. Hak guna usaha diberikan atas tanah yang luasnya paling sedikit 5 hektar, dengan ketentuan bahwa jika luasnya 25 hektar atau lebih harus memakai investasi modal yang layak dan tehnik perusahaan yang baik, sesuai dengan perkembangan zaman

3) Hak guna bangunan adalah hak untuk mendirikan dan mempunyai bangunan atas tanah yang bukan miliknya sendiri, dengan jangka waktu paling lama 30 tahun. Atas permintaan pemegang hak dan dengan mengingat keperluan serta keadaan bangunannya, jangka waktu tersebut dapat diperpanjang dengan waktu paling lama 20 tahun

4) Hak pakai, Pasal 41 adalah hak untuk menggunakan dan/atau memungut hasil dari tanah yang dikuasai langsung oleh Negara atau tanah milik orang lain, yang memberi wewenang dan kewajiban yang ditentukan dalam keputusan pemberiannya oleh pejabat yang berwenang memberikannya atau dalam perjanjian dengan pemilik tanahnya, yang bukan perjanjian sewa menyewa atau perjanjian pengolahan tanah, segala sesuatu asal tidak bertentangan dengan jiwa dan ketentuan-ketentuan Undangundang ini.

Hasil pengumpulan data di lima provinsi (13 kabupaten/kota), tanah timbul yang sudah bersertipikat seluruhnya adalah Hak Milik yang diperoleh melalui redistribusi tanah, konsolidasi tanah dan Prona.

Terhadap tanah timbul yang sudah bersertipikat dan dijadikan jaminan di bank, namun kemudian tanahnya hilang, perlu diatur penanganannya, apakah di biarkan hilang dengan sendirinya, atau perlu ada keterangan dalam SK Pemberian Hak bahwa tanah tersebut berasal dari tanah timbul. Sehingga Bank atau pihak ketiga bisa memilih tetap menerima tanah tersebut sebagai jaminan atau tidak.

Dalam pasal 7 Peraturan Menteri Agraria dan Tata Ruang/Badan Pertanahan Nasional Nomor 17 tahun 2016 tentang Penataan Pertanahan di Wilayah Pesisir dan Pulau-Pulau Kecil, disebutkan hapusnya Hak Atas tanah di wilayah pesisir disesuaikan dengan ketentuan perundang-undangan.

\subsubsection{Subyek Hak Atas Tanah Timbul}

Pasal 15 ayat 3 Peraturan Menteri Agraria dan Tata Ruang/Badan Pertanahan Nasional Nomor 17 tahun 2016 disebutkan bahwa tanah timbul dengan luasan paling luas 100 meter persegi merupakan milik dari pemilik tanah yang berbatasan langsung dengan tanah timbul dimaksud. Pasal ini perlu disempurnakan dengan penambahan ayat untuk orang yang membuka tanah pertama kali. Demikian juga jika tanahnya berada di tengah sungai seperti kasus di Bengkulu Utara, diberikan kepada satu orang (perorangan).

Pembukaan tanah di suatu tempat tertentu merupakan awal dari lahirnya kepemilikan tanah bagi individu atau kelompok, yang menurut hukum adat pembukaan tanah tersebut 
diawali dengan pemberitahuan kepada persekutuan hukum dan diberi tanda dan batas tertentu. ${ }^{36}$

Selanjutnya tanah yang dibuka tersebut dijadikan sebagai tempat berusaha dan atau di atasnya dibangun tempat tinggal yang dikuasai oleh masing-masing orang sesuai dengan kebutuhan dan kemampuannya, hingga penguasaan tanah tersebut berlangsung secara terus menerus dan bahkan turun temurun. Penguasaan tanah yang dilakukan secara terus menerus akan menimbulkan hubungan nyata antara manusia dengan tanah, sehingga dapat dikatakan bahwa hubungan dan tindakan pengolahan nyata atas tanah adalah unsur utama lahirnya hak atas tanah. Berdasarkan penguasaan dan tindakan pengolahan nyata atas tanah secara berkesinambungan tersebut, maka akan menimbulkan hubungan hukum dengan tanah yang ditempati dan diusahakannya, kemudian hubungan hokum tersebut diakui oleh penguasa atau pemerintah setempat yang ditandai dengan pengakuan secara tertulis maupun secara lisan.

\subsubsection{Pendaftaran Hak atas Tanah Timbul}

Awal terbentuknya tanah timbul sangat sulit untuk diketahui. Tidak ada regulasi yang mengatur rentang waktu dapat disebut sebagai tanah timbul. Kalau dikaitkan dengan mulai berlakunya UUPA maka dapat dibuat pengaturan bahwa tanah timbul yang sudah ada sejak tahun 1960 bukan merupakan tanah timbul tetapi tanah milik adat sehingga perolehan haknya melalui konservasi. Sedangkan tanah timbul yang tumbuh setelah berlakunya UUPA maka perolehan haknya melalui proses pemberian hak.

Tanah timbul umumnya sudah dikuasai masyarakat secara fisik baik untuk pertanian, tambak dan perumahan, untuk perolehan haknya secara yuridis dimungkinkan dalam Peraturan Pemerintah Nomor 24 tahun 1997 tentang Pendaftaran Tanah. Pada pasal 24 ayat 2 disebutkan bahwa dalam hal tidak atau tidak lagi tersedia secara lengkap alat-alat pembuktian sebagaimana dimaksud pada ayat (1), pembukuan hak dapat dilakukan berdasarkan kenyataan penguasaan fisik bidang tanah yang bersangkutan selama 20 (dua puluh) tahun atau lebih secara berturut-turut oleh pemohon pendaftaran dan pendahulu pendahulunya, dengan syarat :

a. penguasaan tersebut dilakukan dengan itikad baik dan secara terbuka oleh yang bersangkutan sebagai yang berhak atas tanah, serta diperkuat oleh kesaksian orang yang dapat dipercaya.

b. penguasaan tersebut baik sebelum maupun selama pengumuman sebagaimana dimaksud dalam Pasal 26 tidak dipermasalahkan oleh masyarakat hukum adat atau desa/kelurahan yang bersangkutan ataupun pihak lainnya.

Selanjutnya dalam Peraturan Menteri Negara Agraria Nomor 3 tahun 1998 Ketentuan Pelaksanaan Peraturan Pemerintah Nomor 24 Tahun 1997 Tentang Pendaftaran Tanah, Pasal 60 Ayat 3 menyatakan;

36 Mukhtar Wahid, 2008, Memaknai Kepastian Hukum Hak Milik Atas Tanah, Republika, Jakarta, hlm.59. 
"Apabila bukti kepemilikan sebidang tanah sebagai-mana dimaksud pada ayat (2) tidak lengkap atau tidak ada, pembuktian hak atas bidang tanah itu dapat dilakukan dengan bukti lain yang dilengkapi dengan pernyataan yang bersangkutan dan keterangan yang dapat dipercaya dari sekurang-kurangnya 2 (dua) orang saksi dari lingkungan masyarakat setempat yang tidak mempunyai hubungan keluarga dengan yang bersangkutan sampai derajat kedua baik dalam kekerabatan vertikal maupun horizontal, yang menyatakan bahwa yang bersangkutan adalah benar pemilik bidang tanah tersebut.

Kemudian dalam ayat 4 :

Untuk menilai kebenaran keterangan saksi-saksi atau keterangan yang bersangkutan, sebagaimana dimaksud pada ayat (3), Panitia Ajudikasi dapat :

a. mencari keterangan tambahan dari masyarakat yang berada di sekitar bidang tanah tersebut yang dapat digunakan untuk memperkuat kesaksian atau keterangan mengenai pembuktian kepemilikan tanah tersebut;

b. meminta keterangan tambahan dari masyarakat sebagaimana dimaksud pada huruf a yang diperkirakan dapat mengetahui riwayat kepemilikan bidang tanah.

\subsubsection{Wilayah Pesisir}

Ada beberapa pengertian yang terkait dengan Wilayah Pesisir dan sungai dalam ketentuan perundang-undangan, antara lain :

a) Pasal 1 Undang-Undang Nomor 27 tahun 2007 pasal 1 angka 2 menyebutkan Wilayah Pesisir adalah daerah peralihan antara Ekosistem darat dan laut yang dipengaruhi oleh perubahan di darat dan laut.

b) Perairan Pesisir adalah laut yang berbatasan dengan daratan meliputi perairan sejauh 12 (dua belas) mil laut diukur dari garis pantai, perairan yang menghubungkan pantai dan pulau-pulau, estuari, teluk, perairan dangkal, rawa payau, dan laguna.

c) Kawasan adalah bagian Wilayah Pesisir dan Pulau-Pulau Kecil yang memiliki fungsi tertentu yang ditetapkan berdasarkan kriteria karakteristik fisik, biologi, sosial, dan ekonomi untuk dipertahankan keberadaannya.

d) Sempadan Pantai adalah daratan sepanjang tepian yang lebarnya proporsional dengan bentuk dan kondisi fisik pantai, minimal 100 (seratus) meter dari titik pasang tertinggi ke arah darat.

e) Sempadan sungai berfungsi sebagai ruang penyangga antara ekosistem sungai dan daratan, agar fungsi sungai dan kegiatan manusia tidak saling terganggu.

f) Keputusan Menteri Kelautan dan Perikanan Nomor Kep.10/Men/2003 tentang Pedoman Perencanaan Pengelolaan Pesisir Terpadu di-jelaskan bahwa:

"Wilayah pesisir didefinisikan sebagai wilayah peralihan antara ekosistem darat dan laut yang saling berinteraksi, dimana ke arah laut 12 mil dari garis pantai dan sepertiga dari wilayah laut untuk Kabupaten/Kota dan ke arah darat hingga batas administrasi Kabupaten/Kota." 
Beberapa ketentuan perundang-undangan sudah menentukan batas sempadan pantai, namun demikian penentuan tanah timbul apakah dimulai dari batas sempadan pantai atau sungai perlu di atur lebih lanjut dalam peraturan. Berdasarkan hal tersebut, Pasal 31 Ayat (1) UU Nomor 27 tahun 2007 menyatakan Pemerintah Daerah menetapkan batas sempadan pantai yang disesuaikan dengan karakteristik topografi, biofisik, hidrooseonografi pesisir, kebutuhan ekonomi dan budaya, serta ketentuan lain.

\subsection{Penataan dan Pengendalian Tanah Timbul}

Penguasaan dan pemanfaatan wilayah pesisir berkaitan dengan penatagunaan tanah dan penataan ruang. Orang dan atau badan hukum dapat menguasai dan memanfaatkan wilayah pesisir apabila sesuai dengan rencana tata ruang wilayah kabupaten/kota. Untuk itu diperlukan perencanaan penataan ruang yang baik disertai dengan penatagunaan tanah untuk memberikan akses kepada masyarakat yang ingin memanfaatkan wilayah pesisir.

Dalam pengendalian pemanfaatan tanah timbul oleh masyarakat, pihak pemerintah daerah seharusnya membuat peraturan/regulasi pendukung selain Rencana Tata Ruang Wilayah. Sampai saat ini dari pemerintah Kabupaten Tangerang belum mengeluarkan peraturan yang mengatur tentang pengendalian pemanfaatan tanah timbul. Hal tersebut menyebabkan pengendalian pemanfaatan tanah timbul di sempadan pantai belum cukup efektif karena kurangnya pemahaman masyarakat tentang pentingnya mempertahankan sempadan pantai.

Berdasarkan hasil pengumpulan data di 13 lokasi penelitian Kabupaten dan Kota dimana terdapat tanah yang diindikasikan sebagai timbul, ditemukan hanya beberapa daerah yang mengatur mengenai tanah timbul dalam suatu Peraturan Daerah. Hal ini terjadi karena masih kurang jelasnya kewenangan pengaturan tanah timbul. Dalam peraturan perundangundangan sudah jelas bahwa tanah timbul dikuasai oleh Negara. Namun kewenangan lembaga yang mengawal agar tanah timbul tidak serta merta menjadi lahan untuk dimanfaatkan bahkan mungkin diperebutkan oleh masyarakat masih belum jelas.

Dalam Undang-Undang Nomor 23 Tahun 2014 tentang Pemerintahan Daerah, Setiap daerah memiliki kewenangan penuh atas daerahnya sendiri, maka tiap-tiap kepala daerah mempunyai hak untuk kemudian melakukan penataan ruang. Penataan ruang bukan hanya mengatur struktur ruang yang ada di wilayah daratan saja, tetapi menyangkut seluruh wilayah kabupaten/kota, termasuk wilayah pesisir yang dimilikinya. Wilayah pesisir memiliki arti strategis karena merupakan wilayah peralihan antara ekosistem darat dan laut. Kekayaan sumber daya pesisir dikuasai oleh negara untuk dikelola sede-mikian rupa untuk mewujudkan kesejah-teraan masyarakat. Dengan demikian berdasarkan UU No.23 Tahun 2014 tersebut, Pemerintah daerah mempunyai wewenang untuk membuat Peraturan Daerah (Perda) tentang tanah timbul.

Terhadap ketentuan tersebut baru beberapa Pemerintah Daerah yang menindak lanjuti dalam bentuk Peraturan daerah, antara lain adalah :

1) Pengaturan tanah timbul dalam suatu Perda ditemukan di Provinsi Jawa Barat yaitu Peraturan Daerah Provinsi Jawa Barat No. 6 tahun 2011 tentang Pengurusan Hutan mangrove dan Hutan Pantai, pada :

a) pasal 30 ayat 1 , bahwa tanah timbul merupakan kawasan lindung yang berfungsi sebagai kawasan perlindungan setempat. 
b) pasal 30 ayat 2 disebutkan bahwa tanah yang timbul secara alami meliputi delta, tanah pantai, pulau timbul, dan tanah timbul secara alami lainnya dikuasai oleh negara di bawah pengawasan Gubernur. Pengaturan lebih lanjut belum diatur dalam Perda Kota Cirebon.

c) Pasal 34, Bupati/Walikota menetapkan peruntukan dan penggunaan tanah timbul sebagaimana dalam ayat 1 disesuaikan dengan Rencana tata Ruang Wilayah Provinsi dan Rencana Tata Ruang Wilayah Kabupaten/Kota.

d) Pasal 31, ayat 1 , untuk ketertiban penguasaan tanah timbul oleh pihak tertentu dan untuk menjaga tidak terjadinya kerusakan pantai, di dalam menetakan peruntukan dan penggunaan tanah timbul, ditetapkan jalur lahan konservasi pantai (greenbelt) antara 100-400 meter dihitung dari titik surut terendah sesuai dengan kondisi dan karakteristik pantai.

e) Pasal 32, bahwa penggunaan tanah timbul di jalur konservasi pantai (greenbelt) ditetapkan berdasarkan urutan kegiatan prioritas tertentu seperti kehutanan, perikanan, pertanian, peternakan dan pariwisata.

f) Pasal 33 ayat 1 bahwa tanah timbul yang berbatasan langsung kawasan hutan diprioritaskan menjadi kawasan hutan, selanjutnya pada ayat 2 disebutkan bahwa tanah timbul yang berbatasan langsung dengan tanah di luar kawasan hutan dikuasai oleh Negara di bawah pengawasan Gubernur.

2) Tanah timbul juga diatur dalam Peraturan Daerah Provinsi Jawa barat Nomor 9 tahun 2012 tentang Pengelolaan Wilayah Pesisir dan Pulau-pulau Kecil, dalam pasal 16 ayat 1 , bahwa tanah timbul pada wilayah pesisir harus dimanfaatkan dan dikelola untuk mendukung pulihnya ekosistem pesisir, selanjutnya penjelasan dari pasal 16 ayat 1 tersebut dan tanah timbul secara alami lainnya bahwa yang dimaksud dengan tanah timbul adalah daratan yang terbentuk secara alami maupun buatan karena proses pengendapan di sungai, danau dan pantai yang penguasaan tanahnya dikuasai negara.

3) Pemerintah Kabupaten Indramayu sudah mengeluarkan Perda yaitu Peraturan Daerah Kabupaten Indramayu Nomor : 10 Tahun 2013 Tentang Perubahan Atas Peraturan Daerah Kabupaten Indramayu Nomor 9 Tahun 2003 Tentang Tanah Timbul. Pasal 1 mengatur mengenai definisi tanah timbul, Tanah Timbul adalah daratan yang terbentuk secara alami maupun buatan karena proses pengendapan di sungai, danau, pantai dan/atau lahan timbul, serta penguasaan tanahnya dikuasai negara. Selanjutnya dalam Pasal 5 ayat 1, Untuk ketertiban penguasaan tanah timbul oleh pihak tertentu dan untuk menjaga tidak terjadinya kerusakan pantai, di dalam menetapkan peruntukan dan penggunaan tanah timbul, ditetapkan jalur lahan konservasi pantai (greenbelt) antara 100400 meter dihitung dari titik air surut terendah sesuai dengan kondisi dan karakteristik pantai. Kemudian pada pasal 6, penggunaan tanah timbul diluar jalur lahan konservasi pantai ditetapkan berdasarkan urutan prioritas sebagai berikut :

a) Proyek pembangunan Pemerintah;

b) Proyek pembangunan Swasta;

c) Kehutanan;

d) Perikanan;

e) Pertanian ;

f) Peternakan; 
g) Pariwisata;

h) Pelabuhan;

i) Pemukiman; dan

j) Industri;

Selain tanah timbul di pesisir, ada pula pemanfaatan tanah bekas sungai/kali Cimanuk yang ditutup dan dialihkan, digunakan untuk perumahan, kewenangan ada pada BKSDA.

4) Pemerintah Daerah Provinsi Jawa Timur belum mengeluarkan Peraturan Daerah terkait tanah timbul, namun di kabupaten Tulungagung untuk penggunaan dan pemanfaatan tanah timbul memerlukan ijin dari Balai Pemantapan Kawasan Hutan Wilayah XI Yogyakarta, di Kabupaten Pasuruan melalui Dinas Kelautan dan Perikanan baru sebatas memberikan peringatan kepada warga masyarakat untuk tidak melakukan kegiatan budidaya di kawasan mangrove yang memang terdapat di lokasi tanah timbul Sedangkan untuk Kota Pasuruan, untuk pemberian hak atas tanah timbul perlu rekomendasi dari Pemerintah Daerah.

5) Kabupaten Serang menerbitkan Peraturan Daerah No. 5 tahun 2001 tentang Kawasan Pantai. Dalam Perda ini diatur mengenai :

a) pasal 1, bahwa tanah timbul adalah bidang tanah yang terjadi akibat proses alam di sekitar muara dan pantai.

b) Pasal 4, Obyek pengelolaan kawasan pantai adalah seluruh wilayah Kabupaten yang mempunyai garis pantai yang berstatus Tanah Negara dan wilayah perairan sampai dengan batas 4 (empat) mil dari titik pasang surut ke laut atau sepertiga dari batas kewenangan Propinsi yang diukur berdasarkan ketentuan yang berlaku.

c) Pasal 6, Pemerintah Daerah mempunyai kewenangan untuk:

d) Mengatur dan menyelenggarakan peruntukan penggunaan, persediaan dan pemeliharaan tanah kawasan pantai.

e) Menentukan dan mengatur hubungan hukum dan perbuatan hukum yang berkaitan dengan kawasan pantai.

f) Pasal 7, Kewenangan pengelolaan kawasan pantai ditindak lanjuti dengan penerbitan hak pengelolaan oleh Pemerintah melalui Dinas Pertanahan.

g) Pasal 8, Pemerintah Daerah sebagai pemegang Hak Pengelolaan berwenang untuk:

1. Memberikan ijin pemanfaatan bagian-bagian tanah kawasan pantai pada pihak ketiga berdasarkan perjanjian.

2. Memberikan bagian-bagian kawasan pantai kepada pihak perorangan atau Badan Hukum.

h) Pasal 9, Pemberian bagian-bagian kawasan pantai sebagaimana dimaksud dengan sesuatu hak atas tanah yang meliputi Hak Guna Usaha, Hak Guna Bangunan dan Hak Pakai. Hak atas tanah sebagaimana dimaksud ayat (1) diberikan oleh Pemerintah Daerah melalui Dinas Pertanahan. 


\section{BAB VI}

\section{KESIMPULAN DAN SARAN}

\subsection{Kesimpulan}

1. Persepsi mengenai tanah timbul masih belum sama, penambahan daratan seperti tanah oloran apakah sama dengan tanah timbul, dan untuk pengukuran penambahan daratan apakah menggunakan ketentuan dari garis pantai 100 meter dan garis sempadan sungai 50 meter. Lokasi-lokasi terbentuknya tanah timbul mayoritas berada di wilayah pantai yang berdekatan dengan muara sungai. Proses pembentukan tanah timbul juga sebagian besar merupakan hasil dari sedimentasi aliran sungai tersebut.

Proses awal pembentukan dari tanah timbul sering kali tidak bisa teridentifikasi karena sudah terjadi dalam waktu yang cukup lama. Sehingga penentuan tanah timbul sering kali hanya berdasarkan klaim sebagian pihak saja. Informasi yang diperoleh juga sering kali berdasarkan lisan yang cukup sulit dibuktikan secara spasial.

2. Penggunaan dan pemanfaatkan tanah yang paling sering dijumpai di lokasi tanah timbul berupa lahan budidaya yang dimanfaatkan untuk tambak dan perumahan. Pada lokasi yang berupa tambak ini juga sering ditemukan adanya tanah oloran. Penggunaan tanah yang bukan berupa areal budidaya biasanya berupa tanaman mangrove. Penguasaan tanah timbul oleh masyarakat, biasanya sudah mengusahakannya sejak lama dan turun menurun melalui izin dari pihak desa setempat. Pihak lain yang banyak menguasai tanah timbul adalah instansi kehutanan yang mengklaim penguasaan tanah timbul berdasarkan azas perlekatan dengan kawasan hutan.

Pemilikan tanah timbul pada beberapa lokasi ditemukan masyarakat pengguna sudah bisa memperoleh hak kepemilikan dan diberikan paling banyak melalui mekanisme Prona, Redis dan Konsolidasi Tanah. Sementara pada sebagian yang lokasi lain pemberian hak belum bisa dilakukan karena pemerintah daerah belum memberikan rekomendasi atau karena terindikasi bermasalah.

3. Pemberian hak atas tanah timbul dapat dilakukan berdasarkan wewenang yang diberikan dalam pasal 2 jo pasal 16 UUPA, Peraturan Menteri Agraria dan Tata Ruang/Badan Pertanahan Nasional Nomor 17 tahun 2016 tentang Penataan Pertanahan di Wilayah Pesisir dan Pulau-Pulau Kecil, dalam pasal 6 bahwa pemberian hak atas tanah di wilayah pesisir dilakukan berdasarkan peraturan perundang-undangan dan memenuhi syarat antara lain, peruntukannya sesuai dengan tata ruang wilayah provinsi/kabupaten/kota atau rencana zonasi wilayah, kemudian mendapatkan rekomendasi dari pemerintah provinsi/kabupaten/kota dalam hal belum diatur mengenai peruntukan tanah dalam RTRW. Jika tanahnya hilang, maka hapusnya Hak Atas tanah di wilayah pesisir disesuaikan dengan ketentuan perundang-undangan.

4. Penataan dan pengendalian tanah timbul belum berjalan baik, kewenangan pengendalian apakah ada pada Pemerintah Daerah, BKSDA, atau Kementerian Agraria dan Tata Ruang/BPN, pengendalian sudah mulai dilakukan dengan penerbitan

Peraturan daerah Provinsi dan Peraturan Daerah Kabupaten adapun penataan tanah 
timbul disesuaikan dengan arahan pola ruang wilayah, untuk itu perlu ditingkatkan koordinasi antara Pemerintah Daerah, Kementerian Lingkungan Hidup, Kementerian Agraria dan Tata Ruang/Badan Pertanahan Nasional.

\subsection{Saran}

1. Diperlukan adanya mekanisme penetapan tanah timbul yang sebaiknya dituangkan dalam bentuk petunjuk teknis. Dalam petunjuk teknis itu juga memuat tentang typologi, cara penentuan batas dan pengukuran tanah timbul serta waktu mulai penentuan ditetapkan sebagai tanah timbul. Untuk tanah timbul yang sudah ada sebelum tahun 1960 apakah disamakan dengan tanah timbul yang ada setelah tahun 1960, kesemuanya melalui pemberian hak, atau untuk tanah timbul sebelum tahun 1960 diberikan pengakuan hak.

2. Pemberian hak terhadap tanah timbul sebaiknya juga memperhatikan kepada masyarakat yang memang membuka dan mengusahakan tanah tersebut apalagi sudah ada bukti pemanfaatan dari pihak desa berupa hak garap, dengan tetap memperhatikan kearifan local masyarakat setempat.

3. Macam hak yang diberikan, perlu ada alternative hak lain selain Hak Milik, misalnya Hak Guna Usaha atau Hak Pakai maupun Hak Sewa.

4. Perlunya pengaturan lebih lanjut dari Permen $17 / 2017$ dalam pasal 15 a, luas lebih dari 100 meter harus diberikan rekomendasi, maka bentuk rekomendasi harus ditetapkan. 


\section{DAFTAR PUSTAKA}

Undang-Undang Dasar 1945

Undang-Undang Nomor 5 tahun 1960 tentang Peraturan Dasar Pokok-Pokok Agraria

Undang-Undang Nomor 26 tahun 2007 tentang Penataan Ruang

Undang-Undang Nomor 1 tahun 2014 tentang Perubahan UU Nomor 27 tahun 2007 tentang Pengelolaan Wilayah Pesisir dan Pulau-pulau Kecil

Undang-Undang Nomor 23 tahun 2014 tentang Pemerintah Daerah

Peraturan Pemerintah Nomor 16 tahun 2004 tentang Penatagunaan tanah

Peraturan Pemerintah Nomor 38 Tahun 2011 tentang Sungai

Peraturan Daerah Provinsi Jawa Barat No. 6 tahun 2011 tentang Pengurusan Hutan mangrove dan Hutan Pantai,

Peraturan Menteri Negara Agraria Nomor 17 tahun 2016 tentang Penataan Pertanahan Di Wilayah Pesisir dan Pulau-pulau Kecil

Surat Edaran Menteri Negara Agraria / Kepala Badan Pertanahan Nasional tanggal 9 Mei 1996 Nomor 410-1293 tentang Penertiban Status Tanah Timbul dan Tanah Reklamasi.

Boedi Harsoni, 2005, Hukum Agraria Indonesia : Sejarah Pembentukan Undang-Undang Pokok Agraria, Isi dan Pelaksanaannya, Penerbit Djambatan.

Indria, R. 2003. Upaya penyelesaian sengketa tanah antara Desa mojo dan Desa Pesantren. Universitas Diponegoro.

Maria SW Sumardjono. 2008. Tanah dalam Perspektif Hak Ekonomi, Sosial dan Budaya., PT Kompas Media Nusantara

Maria. S.W. Sumardjono, 2007, Kebijakan Pertanahan : Antara Regulasi dan Implementasi, Kompas, cetakan ke IV, Jakarta,.

Mukhtar Wahid, 2008, Memaknai Kepastian Hukum Hak Milik Atas Tanah, Republika, Jakarta.

Nia Noorrahmah, Reza Munawwir, Frans Almarta, 2014, Tanah Timbul di Kota Cirebon, Peluang dan Tantangan, Magister Perencanaan wilayah dan Kota SAPPK ITB.

P. Astjario dan FX. Harkins, 2005, Penelitian Lingkungan Pantai Wilayah Pesisir Kabupaten Cirebon, jawa barat.

Riza Indria, 2003, Upaya penyelesaian sengketa tanah antara Desa mojo dan Desa Pesantren ,Skripsi Undip, Semarang 
Yuniza Indasari, 2014, Analisis Yuridis Hak Penguasaan Atas Tanah Timbul Berdasarkan Undang - Undang Pokok Agraria Dan Rencana Tata Ruang Wilayah Di Kecamatan Teluk Segara Kota Bengkulu, Skripsi,.

Luky Adrianto, 2017, Tata Kelola Tanah Timbul Untuk Mewujudkan Kesejahteraan Masyarakat, FGD Penyusunan Rumusan Kebijakan Teknis Reklamasi dan Tanah Timbul di Kementerian Agraria dan Tata Ruang/Badan Pertanahan Nasional.

Farida Patittingi, 2008, Hak Atas Tanah Pulau-Pulau Kecil, Disertasi, Program Pascasarjana Universitas Hasanuddin, Makassar.

Wringinanom. 2015. Opini Tentang Pengembangan Wilayah Kabupaten Tulungagung Berdasarkan Sektor Unggulan, (http://puspakrtika.blogspot.co.id/ diakses 26 September 2017).

Neraca Penatagunaan Tanah Kabupaten Cilacap, Kanwil BPN Jawa Tengah, 2013

Neraca Penatagunaan Tanah Kabupaten Kebumen, Kanwil BPN Jawa Tengah, 2013

Neraca Penatagunaan Tanah Kota Cirebon, Kanwil BPN Jawa Barat, 2013

Neraca Penatagunaan Tanah Kabupaten Cirebon, Kanwil BPN Jawa Barat, 2015

Neraca Penatagunaan Tanah Kabupaten Indramayu, Kanwil BPN Jawa Barat, 2015

Updating Data Penatagunaan Tanah Kabupaten Serang, 2014

Hasil Inventarisasi Data Penatagunaan Tanah Kabupaten Tangerang Tahun 2014

Neraca Penatagunaan Tanah Kabupaten Tulungagung.Kanwil BPN Jawa Timur, 2011.

Neraca Penatagunaan Tanah Kabupaten Pasuruan. Kanwil BPN Jawa Timur, 2013.

Neraca Penatagunaan Tanah Kabupaten Mojokerto. Kanwil BPN Jawa Timur, 2016.

Neraca Penatagunaan Tanah Kota Pasuruan.Kanwil BPN Jawa Timur, 2013.

Neraca Penatagunaan Tanah Kota Bengkulu, Kanwil BPN Bengkulu, 2012

Neraca Penatagunaan Tanah Kabupaten Bengkulu Utara, Kanwil BPN Bengkulu, 2011

Badan Pusat Statistik.2013. Tulungagung dalam angka 2013. Badan Pusat Statistik Kabupaten Tulungagung.

https://id.wikipedia.org/wiki/Kabupaten_Cilacap

https://id.wikipedia.org/wiki/Kota_Bengkulu 